\title{
rommhalina
}

(8)

\section{Aires Barbosa na cosmopólis renascentista}

Autor(es):

Pantani, Italo, ed. lit.; Miranda, Margarida, ed. lit.; Manso, Henrique, ed. lit.

Publicado por: Imprensa da Universidade de Coimbra; Sapienza. Universitá di Roma

URL

persistente:

URI:http://hdl.handle.net/10316.2/29855

DOI:

DOI:http://dx.doi.org/10.14195/978-989-721-044-0

Accessed : $\quad$ 26-Apr-2023 14:05:18

A navegação consulta e descarregamento dos títulos inseridos nas Bibliotecas Digitais UC Digitalis, UC Pombalina e UC Impactum, pressupõem a aceitação plena e sem reservas dos Termos e Condições de Uso destas Bibliotecas Digitais, disponíveis em https://digitalis.uc.pt/pt-pt/termos.

Conforme exposto nos referidos Termos e Condições de Uso, o descarregamento de títulos de acesso restrito requer uma licença válida de autorização devendo o utilizador aceder ao(s) documento(s) a partir de um endereço de IP da instituição detentora da supramencionada licença.

Ao utilizador é apenas permitido o descarregamento para uso pessoal, pelo que o emprego do(s) título(s) descarregado(s) para outro fim, designadamente comercial, carece de autorização do respetivo autor ou editor da obra.

Na medida em que todas as obras da UC Digitalis se encontram protegidas pelo Código do Direito de Autor e Direitos Conexos e demais legislação aplicável, toda a cópia, parcial ou total, deste documento, nos casos em que é legalmente admitida, deverá conter ou fazer-se acompanhar por este aviso.

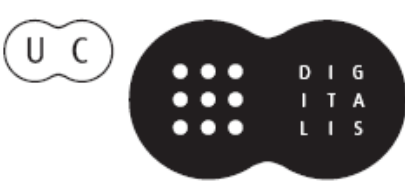




\section{Aires Barbosa na}

\section{Cosmopólis Renascentista}

Italo Pantani, Margarida Miranda \& Henrique Manso (coordenadores)

IMPRENSA DA UNIVERSIDADE DE COIMBRA

SAPIENZA. UNIVERSITÁ DI ROMA 



\section{Aires Barbosa na}

\section{Cosmopólis Renascentista}

\section{Italo Pantani, Margarida Miranda \& Henrique Manso (coordenadores)}


Todos os Volumes desta SÉRIE SÃo SUJeItos A ARbitragem CIENTífica INDEPENDENTE.

Título • Aires Barbosa na Cosmopólis Renascentista

Coordenadores - Italo Pantani, Margarida Miranda \& Henrique Manso

\section{Série Hvmanitas Svpplementvm}

Coordenador Científico do plano de edição: Maria do Céu Fialho

\section{Conselho Editorial}

José Ribeiro Ferreira

Francisco de Oliveira

Maria de Fátima Silva

Nair Castro Soares

Director Técnico: Delfim Leão

Obra realizada no Âmbito das actividades da UI\&D

Centro de Estudos Clássicos e Humanísticos

\section{EDIÇÃo}

Imprensa da Universidade de Coimbra

URL: http://www.uc.pt/imprensa_uc

E-mail: imprensauc@ci.uc.pt

Vendas online:

http://livrariadaimprensa.uc.pt

CoORdenAÇÃo EDITORIAL

Imprensa da Universidade de Coimbra

Concepção gráfica \& Paginação

Rodolfo Lopes \& Nelson Ferreira

\section{Pré-IMPRESSÃo}

Imprensa da Universidade de Coimbra

\section{Impressáo e Acabamento}

SiMỐES \& LiNHARES

ISBN

978-989-721-043-3

ISBN DigITAL

978-989-721-044-0

\section{DOI}

http://dx.doi.org/10.14195/978-989-721-044-0

\section{Depósito Legal}

$368791 / 13$

$11^{\text {a }}$ EdiçÃo: IUC • 2014

\section{(C) JANEIro 2014 .}

IMPRENSA DA UNIVERSIDADE DE CoImBRA

Classica Digitalia Vniversitatis Conimbrigensis (http://classicadigitalia.uc.pt)

Centro de Estudos Clássicos e Humanísticos da Universidade de Coimbra

Reservados todos os direitos. Nos termos legais fica expressamente proibida a reproduçáo total ou parcial por qualquer meio, em papel ou em edição electrónica, sem autorizaçáo expressa dos titulares dos direitos. É desde já excepcionada a utilização em circuitos académicos fechados para apoio a leccionação ou extensâo cultural por via de e-learning. 


\section{SUMÁRIO}

$\begin{array}{ll}\text { Apresentação } & 7\end{array}$

O primeiro Humanismo ibérico 9

Nair de Nazaré Castro Soares (Universidade de Coimbra)

Aires Barbosa e l'esperienza poetica dell'umanesimo italiano

Italo Pantani (“La Sapienza”, Università di Roma)

Luís da Cruz e companhia na correspondência de Manuel Correia

Manuel José de Sousa Barbosa (Universidade de Lisboa)

Aires Barbosa, Professor, pedagogo, filólogo e poeta

Sebastião Tavares de Pinho (Universidade de Coimbra)

A VIAGEM MARÍTIMA COMO METÁFORA DA CRIAÇÃo LITERÁRIA: O EXEMPLO PARADIGMÁTICO de Aires Barbosa

Sebastião Tavares de Pinho (Universidade de Coimbra)

A edição quinhentista do COMENTÁrio barbosiano À HISTORIA APOSTOLICA DE ARÁtor

José Henrique Rodrigues Manso (Universidade da Beira Interior)

Lucrécio e Aires Barbosa

Comentário a Arátor, Histórla ApostólicA, II. XI; Lucr. 2.999-1001

Ana María S. Tarrío (Universidade de Lisboa)

ÍNDICE ONOMÁSTICO 



\section{Apresentação}

A centena e meia de páginas que compõe este volume corresponde à intenção do Centro de Estudos Clássicos e Humanísticos e da Associação Portuguesa de Estudos Neolatinos da Universidade de Coimbra, juntamente com La Sapienza - Universidade de Roma, de celebrar condignamente o quinto centenário do início da produção humanista de Aires Barbosa. Uma homenagem justa, porventura tardia, passados 500 anos sobre a sua primeira publicação, o De Verbis Obliquis (Salamanca, 1511).

Sai agora a lume o presente livro, exatamente meio milénio depois de o célebre humanista aveirense ter iniciado, em 1513, na universidade salmantina, um curso sobre a epopeia de Arátor, Historia apostolica, que materializaria num extenso e minucioso comentário ao poema, publicado três anos mais tarde trata-se da sua obra-prima e a que mais estudos tem suscitado por parte dos poucos (bélas) investigadores barbosianos.

Este merecido tributo é prestado na cidade de Coimbra, onde também Barbosa publicou, em 1536, a Antimoria, medindo-se com o humanista de Roterdão ao rebater o famoso Encomium Moriae. Era de facto preciso ser-se grande para desafiar os maiores. E Aires Barbosa era-o... Um grande poeta, um grande conhecedor dos antigos e dos modernos, um grande pedagogo que, pela excelência e pioneirismo do seu ensino, obrigaria doravante a academia a apelidá-lo Mestre Grego, pois foi ele o primeiro a ensinar a língua de Homero nas universidades ibéricas.

A abrir este conjunto de estudos, Nair Castro Soares traça-nos o cenário da primeira etapa da aventura humanista portuguesa, desde a corte de Avis até ao final do primeiro quartel do séc. XVI, período a que a autora chama com propriedade "Primeiro Humanismo ibérico" e onde o nome do Comentador da Historia apostolica tem o devido destaque. E tal como Aires Barbosa fez soprar os ventos humanistas em Salamanca inspirado pelo seu mestre florentino 
Ângelo Policiano, não poderia esta publicação dispensar um olhar italiano sobre a obra do renascentista português. Italo Pantani dá-nos a conhecer esse panorama de influências adquiridas em Itália que se repercutiram mais tarde na atividade de Aires Barbosa como docente e, sobretudo, como poeta.

Sebastião Pinho apresenta dois textos, o primeiro acerca da atividade pedagógica e poética de Aires Barbosa, brindando-nos com traduções de alguns epigramas; o segundo sobre a viagem marítima como metáfora da criação literária, um topos muito frequente na obra em prosa e em verso do humanista aveirense. A intensa dedicação que Sebastião Pinho tem votado a Aires Barbosa, seu conterrâneo, tem produzido frutos substanciais, materializados em artigos, livros, dissertações e teses acerca da obra do humanista. É sobre uma dessas publicações, o Comentário à Historia apostolica, que Henrique Manso, díscípulo e orientando de Sebastião Pinho durante mais de uma década, reflete no seu artigo, dando a conhecer, principalmente, aspetos editoriais e tipográficos da obra, publicada na cidade de Salamanca em 1516. Ana María Tarrío também aborda o Comentário barbosiano, analisando detalhadamente uma citação de Lucrécio, no contexto da receção do filósofo latino durante o período renascentista, particularmente em Itália, onde Barbosa fez a sua formação humanista.

Se entre os grandes humanistas lusos Aires Barbosa ocupa um lugar pioneiro, pois quase toda a sua obra é publicada no início de Quinhentos, Luís da Cruz é um nome incontornável nos começos do século seguinte. Da sua obra e dos seus méritos literários nos fala detalhadamente Manuel Barbosa, que reflete ainda sobre o papel crucial da Companhia de Jesus no humanismo seiscentista em Portugal.

Impõe-se finalmente a questão: com esta homenagem colocaremos devidamente Aires Barbosa na cosmópolis renascentista? É um primeiro passo, sobretudo quando se aproximam efemérides importantes da vida e obra do Aveirense que urge celebrar. Contamos, por isso, com o contributo dos que se dedicam às humaniores litterae para prestarmos a Aires Barbosa o devido reconhecimento, ou, para usar as palavras de Camões, "o bem que outrem merece e o Céu deseja” (Lus., I, 39).

Covilhã, 10 de maio de 2013 José Henrique Manso 


\section{O PRIMEIRO HUMANISMO IBÉRICO}

Nair de Nazaré Castro Soares

Universidade de Coimbra

Falar do Primeiro Humanismo ibérico é necessariamente reflectir sobre o movimento cultural e filológico em Itália. A influência do Quattrocento italiano, com a sua forte componente retórica, posta ao serviço do humanismo cívico e pedagógico, manifestou-se em Portugal desde a dinastia de Avis.

Vários foram os factores que a propiciaram. Entre eles, as relações com a corte de D. João II de Castela, em ligação, por afinidade familiar, com o reino de Nápoles de Afonso V, o Magnânimo - paradigma do "principe umanizzato" do Renascimento. Ou ainda a presença da cultura italiana, na corte de Borgonha da Duquesa Isabel, filha do nosso rei D. João I - casada com Filipe o Bom, duque da Borgonha e conde da Flandres. Esta corte, a mais brilhante e faustosa da Europa, mantinha ao seu serviço portugueses cultos e acolhia uma verdadeira escola de artistas de iluminuras, de que é testemunho o Livro de Horas do rei $D$. Duarte; e contava ainda com uma das bibliotecas mais famosas do tempo ${ }^{1}$. Mas é sobretudo o contacto directo de D. Pedro, o Infante das Sete Partidas, com a cultura europeia, e designadamente com o humanismo italiano, que permitiu o desabrochar dos ideais humanistas, em Portugal.

A nova era, a que a corte de Avis serviu de pórtico, caracteriza-se já por um enorme interesse pela formação dos cidadãos, à semelhança do famoso "humanismo cívico" florentino, que empenhou figuras como Coluccio Salutati, que se tornou chanceler de Florença; o seu discípulo Leonardo Bruni - tradutor incansável de Aristóteles e de muitos outros autores da literatura grega para latim -; o filósofo Marsilio Ficino, tradutor latino de Platão; e ainda os representantes de todos os domínios da cultura, num ambiente artístico e intelectual vivíssimo, de que é exemplo paradigmático Leon Battista Alberti.

${ }^{1}$ Vide D. Gallet-Guerne, Vasque de Lucène et la Cyropédie à la cour de Bourgogne (1470). Le traité de Xénophon mis en français d'après la version latine du Pogge. Étude, édition des livres I e V. Genève, 1974: 15 e sqq.; G. Looten, "Isabelle de Portugal, duchesse de Bourgogne et comtesse de Frandre", Revue de littérature comparée 49 (1938) 5-22; Ch. C. Willard, "Isabel of Portugal patroness of Humanism?", Miscellanea di studi e ricerche sul Quattrocento francese, a cura di Franco Simone, Torino, 1938: 517-544. Entre as figuras do séquito de D. Isabel de Portugal, está Afonso de Lucena, médico da princesa. O filho, Vasco de Lucena, pôde estudar nas universidades de Colónia e Paris e foi chamado a colaborar na educação do príncipe, o futuro Carlos o Temerário. Foi também Vasco de Lucena tradutor para francês de obras de autores clássicos, como os Faits d'Alexandre de Quinto Cúrcio (1468) e a Ciropedia de Xenofonte, feita a partir da tradução latina de Poggio Bracciolini, com o título Traité des faictz et haultes provesses de Cyrus (1470). Vasco de Lucena não pode confundir-se com o humanista Vasco Fernandes de Lucena, que integrou o escol de humanistas da corte dos Príncipes de Avis e desempenhou funções políticas e diplomáticas importantes, no tempo dos reis D. Afonso V e D. João II. 
São, na verdade, os primeiros humanistas italianos, empenhados na vida pública das suas cidades e na formação integral dos concidadãos, os mentores de uma educação aristocrática. Foi também esse espírito de serviço da comunidade que levou os ínclitos infantes ou o escol intelectual do país a verterem os autores clássicos de latim em "lingoajem", "por aproveitar aos portugueses amadores de virtude que nom som, ou ao diante nom forem latinados", como declarava o infante D. Pedro, na carta dedicatória, que introduz a sua versão do Livro dos ofícios de Marco Tullio Ciceram, a primeira tradução do latim feita em Portugal ${ }^{2}$. O afã de tradutores de obras clássicas, especialmente Cícero e Séneca, de tratados de arte militar, de panegíricos imperiais, é indício seguro das preocupações de um país de aspiração ultramarina, apostado em acertar o passo com os grandes centros culturais europeus ${ }^{3}$.

Nas suas viagens pela Europa (1424-1428) - Inglaterra, Flandres, Hungria, Itália (Veneza, Pádua, Florença e Roma) - o Infante D. Pedro relaciona-se com humanistas italianos, tais como Ambrogio Traversari - que lhe dedica a tradução do De Prouidentia de S. João Crisóstomo ${ }^{4}$-, e Pier Paolo Vergerio (1370-1444), que conheceu na corte de Segismundo da Hungria.

Foi Vergerio autor de uma obra 'Sobre os nobres costumes e os estudos liberais da juventude', o De ingenuis moribus et liberalibus studiis adolescentiae (1402), o primeiro tratado pedagógico, na verdadeira acepção da palavra, quer pelo teor prático da sua doutrina, quer pela real divulgação que conheceu em toda a Europa. A partir deste tratado de Vergerio, impunham-se, como cartilha de educação aristocrática, a obra de Cícero, que, no seu sincretismo, fazia a síntese do pensamento retórico e filosófico da Antiguidade grega; a Institutio oratoria de Quintiliano e o De liberis educandis de Plutarco, obras que se tornaram verdadeiro Vademecum da pedagogia humanista, em moldes modernos.

O tratado de Vergerio, que privilegiava a formação do carácter sobre a aquisição cumulativa de conhecimentos, verdadeiro lema da educação moderna - que, em pleno humanismo, Montaigne consagra na expressão "plutôt une tête bien faite que bien pleine" e os jesuítas traduzem sentenciosamente no ideal Non multa sed multum -, conheceu a maior divulgação nos séculos XV e XVI, a ajuizar pelas centenas de manuscritos e pelas mais de trinta edições incunabulares 5 .

${ }^{2}$ Infante D. Pedro, Livro dos ofícios de Marco Tullio Ciceram. Edição crítica, segundo o ms. de Madrid, prefaciada, anotada e acompanhada de glossário, por Joseph M. Piel, Coimbra, 1948.

${ }^{3}$ Luís de Matos, "O ensino na corte durante a dinastia de Aviz". In: O Humanismo Português 1500-1600. Lisboa: Academia das Ciências de Lisboa, 1988: 499-592.

${ }^{4}$ Não poderemos ignorar que Ambrogio Traversari, integrado no círculo de amizades de famosos pedagogos do Quattrocento, é autor de uma vasta correspondência com o escol intelectual da época, documentário seguro e indispensável para se avaliar da pedagogia praticada na "Giocosa" de Vittorino da Feltre.

${ }^{5}$ É curioso observar que uma colectânea da Biblioteca Geral da Universidade de Coimbra 
Traduziu o tratado de Vergerio, a pedido do Infante D. Pedro, Vasco Fernandes de Lucena. Esta tradução, hoje perdida, mas que figurava ainda entre os livros da biblioteca de D. João $\mathrm{V}$, terá tido grande influência na cultura portuguesa, em geral, e designadamente na orientação humanística da dinastia de Avis

Além da obra de Vergério, Vasco Fernandes de Lucena verte "em lingoajem” os tratados de Cícero e o Panegírico de Trajano de Plínio-o-Moço, que difundem o ideal do orador e de homem de estado ${ }^{6}$. Este humanista português - que fora embaixador de D. Duarte ao concílio de Basileia e ao papa Eugénio IV, e de D. João II ao papa Inocêncio VII - e que ainda vivia no tempo de Cataldo, que a ele alude na sua correspondência, foi um dos tradutores mais activos dos autores clássicos, ao serviço dos ideais pedagógicos e cívicos dos príncipes de Avis.

Entre 1421 e 1431, por diversos períodos, encontra-se em Portugal, em missão diplomática, Alonso de Cartagena, futuro Bispo de Burgos, tradutor de Cícero e Séneca, cuja permanência em Itália e convívio com humanistas famosos são bem elucidativos da sua cultura e gosto pelos valores do humanismo nascente ${ }^{7}$. Ao rei D. Duarte dedica um Memoriale uirtutum, baseado na Ética de Aristóteles - citado e aproveitado no Leal Conselheiro, designadamente no cap. 50 - e a tradução do primeiro livro do De inuentione do Arpinate, indício seguro dos gostos e ideais retóricos da corte de Avis.

$\mathrm{O}$ relacionamento que Cartagena teve com o Humanismo português e com humanistas na corte lusa teve singular importância na orientação retórica do humanismo castelhano, que muito deve ao proto-humanismo da corte de Avis, segundo prova Tomás González Rolán ${ }^{8}$.

(cota: R-10-13) contém oito peças de autores diferentes e entre elas figuram o De ingenuis moribus et liberalibus studiis adolescentiae de Vergério, bem como uma cópia manuscrita da oração de Salvador Fernandes ao 2o Marquês de Vila Real, D. Fernando de Meneses, protector e cultor do Humanismo nascente. Acolhe humanistas no seu palácio, onde só se fala latim, e dá uma educação moderna a seus filhos, D. Pedro de Meneses e D. Leonor de Noronha, discípulos dilectos de Cataldo.

${ }^{6}$ Vasco Fernandes de Lucena revela já o gosto da correcta e elegante expressão na língua do Lácio, tão característica do humanismo renascentista. Prova-o a sua correspondência com Poggio Bracciolini, no sentido de melhorar o estilo de latim, a sua arte oratória. A orientação que ele deve seguir, aconselha o humanista italiano, era a leitura assídua de Quintiliano e, sobretudo de Cícero. Vide as três cartas de Poggio Bracciolini a Vasco Fernandes de Lucena, contidas no Cod. Plut. no 720, c.85b, c.96a, c.109a da Biblioteca Laurenziana de Florença.

${ }^{7}$ Alonso de Cartagena dedica ao rei D. Duarte a tradução do primeiro livro do De inuentione do Arpinate (iniciado em Portugal e concluído em 1531, já em Espanha) e um Memoriale uirtutum, baseado na Ética de Aristóteles .Vide e. g. T. González Rolán; A. Moreno Hernández, Pilar Saquero Suárez- Somonte, Humanismo y Teoría de la Traducción en España e Italia en la primera mitad del siglo XV. Edición y estudio de la Controversia Alphonsiana (Alfonso de Cartagena vs. L. Bruni y P. Candido Decembrio). Madrid, 2000: 194- 205.

${ }^{8}$ Sobre D. Alonso de Cartagena e a importância da sua permanência em Portugal para a definição do humanismo espanhol, vide Tomás González Rolán, "Proyección política y 
Aliás no cap. 99 do Leal Conselheiro, D. Duarte sistematiza os procedimentos básicos para se realizar umaboa tradução. Os seus "Avisamentos" denunciam a interpretação humanista, na confluência da tradição retórica e da tradição patrística e - sem qualquer referência à polémica gerada por Alonso de Cartagena em torno da tradução de Leonardo Bruni da Ética a Nicómaco (1416-1417) - apresentam uma tomada de posição que vai ao encontro da de Bruni no seu tratado De recta interpretatione, uma obra amadurecida pela prática e pela reflexão.

A par deste proto-humanismo da corte de Avis, afirma-se o gosto pelos romances de cavalaria, pelos tratados de educação de príncipes e por uma produção historiográfica, em que as acções de figuras individuais de reis e senhores servem de paradigmas e exempla. Quebrada a tradição da poesia lírica trovadoresca, cabe agora a estas obras em prosa, com uma função didáctica e exemplar, a apologia do ideário da própria dinastia, sem raízes numa lídima sucessão hereditária. Elas desempenham um papel significativo na consolidação do conceito de Estado e na definição dos direitos e deveres de governantes e governados.

O ensino em Portugal, apesar das medidas tomadas no sentido da sua modernização e actualização, apresenta-se ainda carenciado em relação à Europa. Reconhece-o o Infante D. Pedro, o mais culto da ínclita geração: no Livro da Virtuosa benfeitoria, dentro da sua concepção ética dos "deveres do senhoryo”, e ainda na famosa carta de Bruges, escrita entre 1425 e 1426, que apresenta um programa político de renovação cultural. Dirigida ao futuro rei D. Duarte, nela tece D. Pedro considerações de singular interesse sobre uma reforma estrutural profunda do ensino, conforme o modelo dos Colégios de Paris e Oxford, que então visitara ${ }^{10}$.

Em seu entender, não só o clero possuiria uma instrução mais sólida, benéfica ao desempenho do seu munus diuinum, como ainda se corrigiria o povo, cresceriam os letrados e as ciências, o que seria muito proveitoso à

pedagógica del prólogo a la Rethórica de Cicerón dedicado por Alfonso de Cartagena al infante D. Duarte" in Nair Castro soares, Margarida Miranda e Carlota Miranda Urbano, Homo eloquens homo politicus: a retórica e a construção da cidade na Idade Média e no Renascimento, Coimbra, Classica Digitalia, CECH-UC, 2011: 65-92.

${ }^{9}$ Lembro, de Fernão Lopes, as Crónicas de D. Pedro, D. Fernando e D. João I; de Zurara, a Crónica da tomada de Ceuta e a Crónica dos feitos da Guiné, um verdadeiro panegírico da figura do Infante D. Henrique, caracterizado pelos seus dotes intelectuais e rodeado de sábios; de Rui de Pina, as Crónicas de D. Duarte, D. Afonso V e D. João II. Destinadas a relatar as proezas cavaleirescas e os feitos heróicos dos grandes senhores são as Crónica do Infante D. Fernando, de Frei João Álvares, e as Crónicas de D. Pedro de Meneses e de D. Duarte de Meneses, de Gomes Eanes de Zurara.

${ }^{10}$ Nair N. Castro Soares, "A Virtuosa Benfeitoria, o primeiro tratado de educação de príncipes em português", Biblos 69 (1993) - Actas do Congresso Comemorativo do $6^{\circ}$ Centenário do Infante D. Pedro (Coimbra, de 25 a 27 de Novembro de 1992), Coimbra: 289-314. 
administração régia. É notável a modernidade do seu pensamento pedagógico, antropológico e sócio-político, expresso embora numa lógica discursiva, própria das quaestiones medievais. Apesar disso, a sua prosa é semeada de expressões de um colorido e de uma graça imagética surpreendentes.

Muito embora se afigure notável este interesse em proceder à reforma da universidade portuguesa, de acordo com as necessidades da época, continua a observar-se a presença dos nossos estudantes nas universidades estrangeiras, nomeadamente em Itália ${ }^{11}$.

A Universidade portuguesa, produto da sensibilidade e das concepções científicas medievais, mantivera, desde a fundação por D. Dinis até ao século XV, a mesma estrutura e o mesmo plano de estudos. Com o Infante D. Henrique por protector, vai adquirir instalações próprias e o seu plano curricular vai ser reestruturado e revitalizado com o ensino integral das sete artes liberais, como estipula na famosa carta de 12 de Outubro de 1431; a partir de então, vai incluir, além das artes sermocinales do trivium, as disciplinas do quadrivium (a Aritmética, a Geometria, a Astronomia e a Música) e a Filosofia Natural e Moral, ou seja, a filosofia de Aristóteles. Assim se contemplavam o estudo científico e a observação da natureza, saberes indispensáveis à empresa dos Descobrimentos. Apesar disso, a reforma henriquina não terá vingado completamente, e a situação do ensino superior não conheceu progressos significativos.

Quando, em 1508, os "Estatutos Manuelinos" ratificam o que constituiria a estrutura formal dos cursos de Artes, apenas se referem a Gramática e a Lógica e não incluem a Retórica ${ }^{12}$.

$\mathrm{Na}$ verdade, a abertura ao movimento humanista e aos novos métodos pedagógicos não se fez sem uma certa resistência da instituição universitária. Foi sobretudo na corte, e dentro do mecenatismo régio ao ensino dos nobres, que, tanto em Portugal como na Espanha, a modernidade no ensino das bumaniores litterae se impôs definitivamente.

Desde a dinastia de Avis, a corte torna-se o grande centro cultural, incentivando a criação literária e a prática da leitura. Formam-se as primeiras bibliotecas, como as de D. Fernando e D. Duarte. De Itália vêm os educadores de D. Afonso V, Estêvão de Nápoles e Mateus de Pisano. Este humanista

${ }^{11}$ Vide A. D. Sousa Costa: "Estudos superiores e universitários em Portugal no reinado de D. João II”. In: Biblos 63 (1987): 253-334; J. V. de Pina Martins, Humanisme et Renaissance de l'Italie au Portugal, 2 vols. Lisboa, 1989: 407-448.

12 Documenta já esta ratio studiorum, o primeiro discurso pronunciado numa universidade portuguesa, em 1 de Outubro de 1504, que chegou até nós. Cf. D. Pedro de Meneses, Oração proferida no Estudo Geral de Lisboa (Oratio habita a petro menesio comite alcotini coram Emanuele Serenissimo Rege in scholis ulyxbonae), ed. de A. Moreira de Sá e tradução de Miguel Pinto de Meneses, 1964: 46-47. Assim se comprova o maior incremento dado à Retórica e às Humanidades, no ensino da corte do que na instituição universitária. Cf. infra, n. 35 
escreve sobre a guerra de Ceuta o De bello Septensi, considerado o primeiro texto latino de teor humanístico.

Mais tarde, já no reinado de D. João II, chega Justo Baldino, que seria encarregado de cantar em latim a gesta lusa, sem que levasse a efeito tal empresa. Tudo evidencia como o reino português se preparava, a passo firme, para o alvorecer da Idade Moderna.

D. Afonso V, louvado pela sua cultura intelectual, organiza, no Paço da Alcáçova, em Lisboa, o núcleo da futura Livraria Real, que abre, pela primeira vez as portas ao público ${ }^{13}$.

Os nobres, sobretudo, mandavam educar os filhos para fora do reino, facto que levou os procuradores do povo a pedirem a $\mathrm{D}$. Afonso $\mathrm{V}$, nas cortes de 1473, e a D. João II, nas de 12 de Novembro de 1481, que se limitassem as tenças e pensões régias concedidas aos estudantes.

No último quartel do século XV, em 1485, chega a Portugal Cataldo Parísio Sículo, que é considerado o introdutor do Humanismo entre nós. Doutor em Direito Civil e Pontifício pela Universidade de Ferrara e mestre na de Bolonha - a sua Bolonha que tantas vezes evoca com saudade -, deixou a Itália e veio para a afamada corte de Portugal, onde serviu como pedagogo e secretário latino, orator regius, durante os reinados de D. João II e D. Manuel.

$\mathrm{Na}$ qualidade de orator regius redigiu numerosas cartas em latim, ao serviço dos reis D. João II e D. Manuel. Foi ainda no desempenho desta honrosa função que pronunciou, a 28 de novembro de 1490, em Évora, junto à porta de Avis, em nome da cidade, a oração de entrada da princesa Isabel, primogénita dos Reis Católicos e esposa do malogrado príncipe Afonso, filho de D. João II, que viria a falecer tragicamente, por queda do cavalo, a 13 de Julho de 1491. Pronunciada a solene oração, Évora foi cenário, até ao Natal, das festas de celebração do casamento dos príncipes, onde acorreu o país inteiro. Além desta oração, Cataldo compôs uma outra, por ordem do rei D. Manuel, para a entrada solene em Santarém da rainha D. Maria, irmã de D. Isabel, que não chegou a ser proferida ${ }^{14}$. A Cataldo coube a grandeza de enaltecer estas figuras régias femininas, e com elas a Corte dos Reis Católicos. Ambas as filhas destes monarcas, que vieram a ser esposas de D. Manuel, em Portugal, eram cultas e tinham recebido uma esmerada educação humanista.

${ }^{13}$ J. M. Sousa Viterbo, "A cultura intelectual de D. Afonso V", in Arquivo Histórico Português 2 (1904): 255, afirma: «Ele tinha a paixão dos livros, estimava as ciências e as artes e comprazia-se no convívio e correspondência dos eruditos do seu tempo, a quem incitava nos seus trabalhos, galardoando-os merecidamente».

${ }^{14}$ Vide Cataldi Siculi Oratio habita a Cataldo in aduentu Elisabeth Principis Portugaliae, ante ianuam urbis Eborare, in Epistolae et orationes quaedam Cataldi Siculi, fols. A ij-A iiij vo. Estas duas orações mereceram um estudo moderno.Vide Cataldo Parísio Sículo, Duas orações: Prólogo, tradução e notas de M. Margarida B. Gomes da Silva. Introdução e revisão de A. Costa Ramalho. Coimbra, 1974. 
A personalidade de Cataldo e a sua sintonia com o ideário que tão profundamente marcou esta época são bem conhecidas através da obra que nos legou. Com esta figura se prende o que de mais seguro e documentado se conhece sobre a cultura e a retórica de corte, no primeiro humanismo em Portugal.

É sobretudo desde o tempo de D. João II e D Manuel que a corte portuguesa se torna permeável ao movimento humanista. Estes reis rodeiam-se de letrados, designadamente juristas - que preparam os regimentos das diversas instituições, pilares do Estado centralizado -, e ainda de homens de ciência, matemáticos, cosmógrafos, astrónomos, homens com conhecimentos teóricos e práticos na arte de navegar e cartografar, que tornam possível o prosseguimento e o êxito da expansão ultramarina.

$\mathrm{O}$ saber dos antigos e sua aemulatio e imitatio, nos diferentes géneros literários, o conhecimento empírico e o exotismo dos novos mundos, a gesta lusa, em verso e em prosa, a literatura dramática que ensina e deleita a nobreza, nos seus serões palacianos, vão merecer, no Renascimento português, divulgação universal na língua latina, ou na "vulgar" e nobre língua materna, através da nova arte da imprensa, conhecida entre nós desde finais do século $\mathrm{XV}^{15}$.

O movimento humanista italiano, além disso, influencia, de forma directa, diplomatas, letrados e eclesiásticos, que tomam parte em embaixadas e concílios, e sobretudo os estudantes que frequentam as Universidades de Bolonha, Pisa, Florença, Pádua, Ferrara, Siena e Roma. Nestas universidades de Itália, onde floresciam as humaniores litterae, estudam os três filhos do chanceler João Teixeira - Luís, Álvaro e Tristão, dos quais se distinguiu como notável jurisconsulto e homem de letras Luís Teixeira, que foi mestre de D. João III e mereceu os elogios de Erasmo em Chrysostomi lucubrationes (1527) -, Aires Barbosa, Henrique Caiado, D. Garcia de Meneses, Martinho de Figueiredo, entre os principais. Viriam eles abrir caminho a muitos outros que, ajudados por D. Manuel e D. João III, se formariam nas escolas mais famosas de então ${ }^{16}$.

${ }^{15}$ Papel basilar, no Renascimento, desempenha a imprensa, cuja invenção Garcia de Resende saúda, na sua Miscelânea, nestes termos: "E viimos em nossos dias/ ha letra de forma achada/ com que a cada passada/ crescem tantas livrarias/ e ha sciencia he augmentada". Cf. Garcia de Resende (1994), Livro das Obras de Garcia de Resende, edição crítica, estudo textológico e linguístico por Evelina Verdelho, Lisboa, Fundação Calouste Gulbenkian: 570. Além de obras de devoção, ou ligadas à prática religiosa, ou à prevenção das doenças, os livros que mais frequentemente são editados, nos finais do séc. XV, princípios do XVI, são relativos à arte de marear, gramáticas, cartilhas de aprender a ler, catecismos, e as Epistolae et orationes de Cataldo, saídas a lume a 21 de Fevereiro de 1500, nos prelos de Valentim Fernandes. Cf. Artur Anselmo, Origens da Imprensa em Portugal. Lisboa, 1981: 289-332.

${ }_{16}$ A Universidade de Salamanca, em Espanha, e as de Itália, que têm a preferência dos 
São estes humanistas, eclesiásticos e juristas portugueses entusiastas decididos da renovação da cultura em Portugal, seguidores dos métodos filológicos de Lourenço Valla e Angelo Policiano, e intérpretes do espírito cívico que impregnou a sensibilidade dos homens do Quattrocento. Assim se ia formando um escol de intelectuais que seria o suporte da administração régia, cada vez mais burocratizada ${ }^{17}$.

Por toda a Europa, os studia humanitatis deixam de limitar o seu âmbito aos auctores medievais e abrem-se à literatura, à filosofia e até à arte da Antiguidade Clássica. $\mathrm{O}$ novo curriculum, alargado à história, à poesia, à ética $\mathrm{e}$ às artes da pintura, escultura, arquitectura e desenho, figura já no Panepistemon de Angelo Policiano.

Dando-se o maior valor ao elemento pessoal, a filosofia moral torna-se um traço característico da vida intelectual deste período, de par com o conhecimento da história e do direito, disciplinas que preparam para a vida activa ${ }^{18}$. Fizera-se ouvir a voz de Cícero, no De oratore (1.5), que acreditava na importância da lição dos antigos, na força dos seus exempla, no conhecimento do direito civil, por isso os recomendava na formação do orador.

O homem do Renascimento apreendeu, enfim, o sentido essencial da retórica, assumida como valor de relação humana e meio de expressão da consciência humanística. E foi numa afirmação de complementaridade do ideal enciclopédico e do ideal retórico, de inspiração clássica, que se impôs uma concepção aristocrática de cultura, a que as cortes europeias da época davam resposta ${ }^{19}$.

Em Espanha, florescia a Universidade de Salamanca com seus mestres de renome, tais como António de Nebrija, o português Aires Barbosa, Hernán Nuñez de Gusmán e os italianos Lúcio Marineo Sículo e Pedro Mártir d'Anghiera. A par do ensino superior institucionalizado, a corte castelhana tornara-se, no seu fervor cultural, uma verdadeira escola de humanidades. Nela ensinou, a convite da rainha, desde 1488, o humanista Pedro Mártir

portugueses durante o século XV, vão cedendo lugar, embora não completamente, no século XVI, a Lovaina e às universidades francesas, onde viriam a estudar humanistas como André de Resende, Damião de Góis e os reformadores do ensino em Coimbra, Frei Brás de Barros e Frei Diogo de Murça. Cf. Nair N. Castro Soares, "Humanismo e Pedagogia", Miscelânea em honra da Doutora Maria Helena da Rocha Pereira - Humanitas 47 (1995) 799-844. 1964.

${ }^{17}$ Vide N. J. Espinosa Gomes da Silva, Humanismo e direito em Portugal no séc. XVI, Lisboa,

${ }^{18}$ P. O. Kristeller, "Umanesimo filosofico e umanesimo letterario", in Lettere Italiane 14. 4 (1962): 391.

${ }^{19}$ Vide e.g. Cesare Vasoli, "Il cortigiano, il diplomatico, il principe. Intellettuali e potere nell' Italia del Cinquecento", in La corte e il cortigiano. II - Un modello europeo, Roma, 1980: 173 e sqq.; para o caso português vide Nair N. Castro Soares, O príncipe ideal no século XVI e a obra de D. Jerónimo Osório. Coimbra, 1994: 246-290. 
d'Anghiera, que teve por aluno D. Jaime, duque de Bragança, por ocasião do seu exílio, no reinado do nosso rei D. João II.

Em Portugal, no entanto, no último quartel do século XV, por ocasião da chegada de Cataldo à corte de D. João II, há já homens cultos e peritos na língua latina. Entre eles, D. Garcia de Meneses, bispo de Évora, filho de D. Duarte de Meneses e neto de D. Pedro de Meneses, primeiro governador de Ceuta e primeiro conde de Vila Real. Páginas de história panegírico-épica nos legou Gomes Eanes de Azurara, nas crónicas particulares dedicadas a cada uma destas figuras: Cronica de D. Pedro de Meneses e Cronica de D. Duarte de Meneses $^{20}$.

É D. Garcia de Meneses, paradigma do ideal de intelectual e de guerreiro, figura da hierarquia eclesiástica e diplomata régio junto da Santa Sé, que avulta pela sua cultura e pela coragem do seu braço armado contra o turco. É no exercício das suas funções diplomáticas que, em 31 de Agosto de 1481, profere um discurso dirigido ao Papa Sisto IV que rivaliza em estilo narrativo com os humanistas italianos. Empenhado em edificar, engrandecer o seu nome e o de sua família, a sua pátria e a cristandade, fala, com orgulho, dos seus ascendentes e suas façanhas, da glória de seu avô e daqueles que «encontraram virilmente a morte, lutando pela fé», seu pai e seu irmão ${ }^{21}$.

Neste discurso inflamado pelo ardor posto na guerra contra o turco e pelo proselitismo cristão - não é despiciendo lembrar quanto a guerra africana contribuiu para preservar a Europa do ataque muçulmano -, se reconhecem não poucos motivos, caros a Camões, n'Os Lusíadas.

Ao ouvir D. Garcia de Meneses discursar, em Roma, em 1481, o humanista Pompónio Leto manifestou o seu assombro, que nos é relatado em carta de Gaspar Barreiros - publicada em apêndice à sua Corografia-, dirigida de Évora a Jorge Coelho, em 28 de Abril de 1553. Gaspar Barreiros conta ao

${ }^{20}$ Sobre estas duas personalidades não faltam relatos históricos. Além da Crónica da tomada de Ceuta, que pretende ser a narração completa deste feito, empreendida a partir de testemunhos orais daqueles que nela intervieram, e do De bello Septensi de Mateus de Pisano sobre o mesmo tema, Zurara escreve crónicas particulares de cada uma destas personagens, Crónica de D. Pedro de Meneses, primeiro capitão de Ceuta depois da conquista, redigida entre 1458 e 1463, e a Crónica de D. Duarte de Meneses, capitão de Alcácer Seguer, composta entre 1464 e 1468, última das produções de Zurara.

${ }^{21}$ Discurso ao Papa Sisto IV (1481) in A. Costa Ramalho, Latim Renascentista em PortugalAntologia. Prefácio, selecção, versão do latim e notas de, Coimbra, ${ }^{2} 1994: 15-18$. Refere-se, neste discurso, a seu avô D. Pedro de Meneses, $1^{\circ}$ conde de Vila Real e primeiro governador de Ceuta; a seu pai D. Duarte de Meneses, conde de Viana, primeiro governador de Alcácer-Ceguer, que morreu em combate em 1466, ao cobrir a retirada de D. Afonso V que ficou a dever-lhe ter escapado com vida (Ruy de Pina, Chronica do Senhor Rey D. Affonso V, cap. CLVI) e a D. Henrique de Meneses, seu irmão, capitão de Arzila, que morreu em combate contra os mouros em 1480. D. Henrique é mencionado na Arcitinge (vv. 357-361), poema épico sobre a conquista de Arzila, de Cataldo Parísio Sículo. 
seu amigo que o Cardeal Sadoleto lhe oferecera «espontaneamente uma coisa que há muito procurava com empenho», isto é, a «oração pronunciada mais ou menos há oitenta anos por D. Garcia de Meneses, bispo de Évora, perante o Sumo Pontífice Sixto IV, e impressa no mesmo ano em Roma pelo processo calcográfico».

D. Garcia de Meneses é, sem dúvida, entre nós, um homem de cultura superior, antes da entrada efectiva do Humanismo em Portugal ${ }^{22}$. Apesar de ocupados na guerra de África, seu avô e seu pai não descuraram a preparação nas armas e nas letras da sua descendência, de que é exemplo acabado D. Garcia de Meneses, que foi estudante em Itália.

Outras figuras se destacaram, nesta época, entre nós: Vasco Fernandes de Lucena, o Chanceler-mor do reino João Teixeira, Salvador Fernandes, ou ainda João Rodrigues Sá de Meneses, alcaide-mor do Porto ${ }^{23}$.

Neste último quartel do século $X V$, período seminal de conquista e afirmação da utilidade da arte oratória, marcado pela colonização dos demais saberes, algumas destas figuras da corte dão-nos, nos seus discursos, uma prova inequívoca da existência entre nós de uma oratória civil24

No reinado de D. João II (1481-1495), desde o seu alevantamento e sobretudo desde as cortes de Évora-Viana (1481-1482), em que se afirma a centralização do poder real, a ars dicendi, marca do humanismo nascente, é colocada ao serviço da ideologia do poder real. Ganha prestígio, ao lado do pregador da corte, a figura do orador régio, com preparação clássica e competência retórica na língua latina. Nestas cortes, que marcam o início do governo e da afirmação incontestável da autoridade do "Príncipe Perfeito", faz a arenga da sessão régia inaugural - como já a fizera no alevantamento deste rei - o orador oficial, o humanista de idade veneranda, «muito distinto e letrado dentro do seu veludo preto», Vasco Fernandes de Lucena ${ }^{25}$. Neste discurso

${ }^{22}$ Sabe-se que D. Garcia de Meneses, regressado de Itália, se envolve activamente na conjura do Duque de Viseu contra D. João II, tendo sido vítima dela e morrido, provavelmente, envenenado.

${ }^{23}$ Vasco Fernandes de Lucena, que, na sua longa vida, vemos ao serviço dos príncipes da "Ínclita geração" e de D. João II, sendo referido na correspondência de Cataldo; ou ainda o Chanceler-mor do reino João Teixeira, cujos filhos foram alunos de Ângelo Policiano, em Florença; ou Salvador Fernandes, laureado com a licenciatura nos Direitos Pontifício e Cesário, que pronunciou uma oração de entrada de D. Fernando de Meneses, 2 Marquês de Vila Real, na capital do seu marquesado; ou ainda João Rodrigues Sá de Meneses, alcaide-mor do Porto - que Sá de Miranda elogia, por realizar a perfeita união das armas e das letras - tradutor de Ovídio e poeta do Cancioneiro Geral, além de autor de um diálogo ao estilo humanista, o De platano.

${ }^{24}$ Belmiro Fernandes Pereira, Retórica e eloquência em Portugal na época do Renascimento. Lisboa, Imprensa Nacional Casa da Moeda, 2012: 360 e sqq.

${ }^{25}$ Ibidem; Armindo de Sousa, As cortes medievais portuguesas (1385-1490). Porto, 1990: 525; Manuela Mendonça, D. João II. Lisboa, 1991: 195. 
deliberativo, exalta o significado da obediência prestada ao rei por grandes e prelados, por fidalgos e povos, recorrendo a argumentos jurídicos, bíblicos e aos autores da Antiguidade, quando, por exemplo, enaltece os costumes dos persas, no que respeita à grandeza conferida à majestade real, de que fala Heródoto - que se torna um tópico da historiografia greco-latina, a que recorre também D. Jerónimo Osório, no seu De regis institutione et disciplina (1572), ou quando refere a obediência e menagem como um dever de justiça, baseado na Rhetorica ad Herennium (livro III, cap. IV), ou no De inuentione, livro II (160-161) de Cícero ${ }^{26}$.

Dentro da mesma estratégia de fortalecimento do poder real, é a elevação ao marquesado do $3^{\circ}$ Conde de Vila Real, D. Pedro de Meneses. A oração proferida pelo Chanceler João Teixeira, em Beja, no primeiro dia de Março de 1489, para honrar D. Pedro de Meneses, que recebe o novo título de Marquês de Vila Real, é, neste particular, bem expressiva. Derrubadas as casas de Viseu e de Bragança, e consolidado o poder do soberano, atinge-se o ponto alto do "período de afirmação" do poder absoluto do rei, na designação de Manuela Mendonça ${ }^{27}$. O significado político deste acto não passou despercebido aos cronistas de D. João II, como Rui de Pina (cap. 37) e Garcia de Resende (cap. 78).

A própria função do orador, chanceler-mor do reino, com amplos poderes judiciais e alto valor político, confere auctoritas a este acto: a oração epidíctica, cujo alarde de cultura humanística se adequava admiravelmente à prosápia dos Meneses, foi proferida perante o rei D. João II, o Príncipe Afonso, o duque de Beja, que será o futuro D. Manuel, e de toda a corte. Significativa se torna a commemoratio do rei, que coloca modernos e antigos na mesma cadeia de exemplaridade, e celebra, na tradição das chriae, tanto o agir como o dizer: têm amplo desenvolvimento o elogio das virtudes do soberano, em armas e letras, o seu amor à cultura, por ter em casa «um peritíssimo mestre» para ensinar o seu filho - uma alusão a Cataldo, seu aliado na expulsão da barbárie -, a esmerada educação aristocrática dada ao Príncipe, a defesa das bumaniores litterae e a diligência posta em expulsar a barbárie, ao «sostentar letrados e doutos». Encarece, por último, os grandes serviços prestados à coroa pelo conde de Vila Real, D. Pedro de Meneses.

A laus do novo Marquês - que se integra na exaltação do poder real, que a figura de D. João II personifica, de que são documento as anteriores orações de Vasco Fernandes de Lucena - é feita de acordo com todos os loci da retórica epidíctica (Arist., Retórica, 1360b) que inclui os bens internos e externos,

${ }^{26}$ Álvaro Lopes de Chaves (1984), Livro de apontamentos (1438-1489), ed. A. M. Salgado. Lisboa, 1984: 62-71.

27 Manuela Mendonça, D. João II. Lisboa, 1991: 373-380. 
com especial realce para a sua linhagem, que em antiguidade e ascendência régia se coloca ao mais alto nível: o das derrubadas casas dos duques de Viseu e de Bragança. Enaltecem-se os serviços prestados à coroa pelo Marquês e pelos seus antepassados, para quem $\mathrm{D}$. Afonso $\mathrm{V}$ tem uma dívida de gratidão, pela sua acção na guerra com Castela e nas batalhas no Norte de África. Era a consagração pública da casa de Vila Real com consequências políticas e culturais assinaláveis.

Escrito em português, este discurso teve singular importância, ao longo do século XVI. Foi traduzido para latim pelo filho do seu autor, Luís Teixeira, versão esta que seria de novo tresladada para vernáculo, em meados de Quinhentos, pelo humanista Miguel Soares, ao serviço do quarto marquês de Vila Real, D. Miguel de Meneses ${ }^{28}$.

Não há dúvida de que estas peças de oratória civil, no dealbar do humanismo renascentista português, nos dão a marca da cultura da corte e da progressiva centralização do poder no reinado do "Príncipe Perfeito". É pela mão deste monarca que a casa de Vila Real atinge o seu fastígio político, que, em breve, se fará acompanhar do maior prestígio intelectual e cultural.

É no tempo de D. Fernando de Meneses, 2o Marquês de Vila Real, e de sua esposa, D. Maria Freire, mulher culta da nobreza, que esta casa acolhe e dá lustre ao nascente humanismo, de carácter filológico, na pessoa de Cataldo e seu magistério ${ }^{29}$.

${ }^{28}$ Vide Miguel Soares, Obra que contem huma Oração do Doutor Luys Teixerira, feyta quãdo fizerã o cõde dô Pedro de Meneses, Marquês de vila Real. E o treslado della em Portugues, por o mestre Miguel Soares: dirigida ao illustrissimo Principe, Eं excelente Senhor dõ Miguel de Meneses. IIII. Marquês de vila Real. Coimbra, João Álvares, 1562; Luís de Matos, L'Expansion portugaise dans la littérature latine de la Renaissance. Lisboa, 1991: 569. A versão latina e a retroversão do discurso quatrocentista foram publicadas nos prelos conimbricences de João Álvares, Impressor da Universidade, em 1562.

${ }^{29}$ Eram alunos dilectos de Cataldo D. Pedro de Meneses e D. Leonor de Noronha, filhos de D. Fernando de Meneses, $2^{\circ}$ marquês de Vila Real, e de D. Maria Freire, que residiam na felicissima vila ribatejana de Santarém, a preferida de Cataldo, entre todas as cidades portuguesas. A D. Leonor se refere o humanista, em carta a D. Manuel, afirmando que pode rivalizar com o irmão D. Pedro, na língua latina. À sua perícia de latinista se deve a tradução da Coronica Geral de Marcantonio Cocio Sabelico (Vide a tradução de latim para português da Coronica geral de Marco António Cocio Sabélico desde o começo do mundo até nosso tempo, Coimbra, João de Barreira e João Álvares, 1550). D. Leonor e muitas outras figuras femininas da nossa nobreza devem às referências de Cataldo, na sua obra, a fama de cultas e de conhecedoras da língua latina: a rainha D. Leonor, esposa de D. João II, protectora de Gil Vicente; a Infanta D. Joana, a Santa Joana princesa de Aveiro; D. Maria Freire, marquesa de Vila Real, mãe de D. Pedro e de D. Leonor; a rainha D. Maria, esposa de D. Manuel. A educação feminina de raiz italiana, a que Luis Vives deu grande impulso, como teorizador pedagógico e como mestre de princesas, é uma realidade entre nós muito antes da já designada «Academia feminina portuguesa» de D. Maria, a filha de D. Manuel. É este um testemunho vivo da educação ministrada entre nós, tal como em Itália, Espanha e Inglaterra, às filhas da aristocracia, a que a teorização de Leonardo Bruni, no seu $D e$ studiis et litteris liber, tinha dado o tom. 
Cataldo vai dar um novo impulso à pedagogia e à cultura no nosso país, sob a égide da corte e da nobreza. Notável é «o seu contributo para a introdução do humanismo e para a actualização do nosso País com a cultura literária da Europa mais adiantada, a partir da fonte que era a Itália» ${ }^{30}$.

A grande abertura ao Humanismo de matriz italiana, ao longo de sucessivas décadas, não bastaria para comprovar a afirmação e difusão do humanismo em Portugal. Necessária se tornava a renovação dos estudos, segundo o programa humanista, os métodos pedagógicos da educação nova, que caracterizam este movimento, tanto na Gramática como na Retórica, como na produção de textos literários.

Apesar do ambiente favorável da corte portuguesa, decisivo para a propagação do Humanismo, estes novos métodos pedagógicos impuseram-se não sem algum conflito, ou mesmo resistência da instituição universitária, tanto em Portugal como em Espanha. Provam-no os epigramas de Aires Barbosa, o humanista de Aveiro, o "Mestre grego", que no seu ensino na Universidade de Salamanca se empenhou na expulsio barbariei. Ou, entre nós, a polémica contra a barbárie gótica e a crítica aos negociantes do «trigo sarnento» de Pastrana assumida por Estêvão Cavaleiro, no Prologus da sua Noua grammatices marie matris dei uirginis, que visava escoliastas pastranos, renitentes à inovação, responsáveis pela sua expulsão da Universidade de Lisboa. Ou o próprio Cataldo, que se afirma, no seu quintilianismo, como o representante aúlico desta luta pela modernidade. A cada passo, exprime Cataldo o seu orgulho em ser filho da Itália, berço da cultura, «onde foi descoberta não só a arte oratória mas, como todos sabem, jorram as fontes das restantes ciências» ${ }^{31}$, e acima de tudo «onde o valor é escudo de si próprio» ${ }^{32}$. Fá-lo sobretudo como protesto do seu próprio mérito de humanista, do seu papel na "expulsão da barbárie", ou como denúncia amarga da incompreensão, ciúme e ignorância de certas pessoas que lhe são hostis na corte portuguesa ${ }^{33}$.

${ }^{30}$ Cataldo Parísio Sículo, Epistolae et orationes quaedam. Edição fac-similada com introdução de A. Costa Ramalho. Coimbra, 1988: 11.

${ }^{31}$ Cf. a carta (Epistolae I, d iij) dirigida a D. Diogo de Sousa, o nobre eclesiástico que foi deão da capela de D. João II e mais tarde bispo do Porto e arcebispo de Braga. Cf. A. Costa Ramalho, Estudos sobre a época do Renascimento. Lisboa, ${ }^{2}$ 1997: 96.

32 Vide a «Lamentação» em verso, escrita entre 1495 e 1499 e dirigida a D. João Manuel, o sentencioso camareiro-mor do Cancioneiro Geral: Querimonia ad Ioannem Emmanuelem, in Poemata, fol. k iiij-1; reimpr. Conquestio ad Dominum Ioannem Emmanuelem Regis Emmanuelis Primum Cubicularium, in D. António Caetano de Sousa, Provas da História Genealógica da Casa Real Portuguesa, Tomo VI, ii parte, nova edição revista por M. Lopes de Almeida e César Pegado, Coimbra, 1954: Tomo VI, ii parte, 182-183.

${ }^{33}$ Estas confissões e desabafos sobre mestres, educadores, historiadores, oradores oficiais e poetas áulicos encontram-se, por exemplo na referida «Lamentação» diririgida a D. João Manuel e principalmente nas cartas endereçadas a D. Diogo de Sousa, que lhe serve de escudo nas horas difíceis. Cf. A. Costa Ramalho, Latim Renascentista em Portugal-Antologia. 
Só por finais do século $\mathrm{XV}$, a pouco e pouco e não por via institucional, se verifica uma mudança de perspectiva e de conteúdos no ensino gramatical: com a lição de Quintiliano, os humanistas reforçam a ligação da Gramática à Retórica, de forma a transformar um saber meramente linguístico em disciplina de estudos literários; o ensino da retórica, ou a retoricização da gramática, orienta-se no sentido da aquisição da eloquentia. A recte loquendi scientia deixa-se contaminar pela ars bene dicendi, em que gramática, retórica, dialéctica e poesia se interpenetram e confluem, numa identificação de objectivo comum ${ }^{34}$.

É esta a lição que nos apresenta o discípulo de Cataldo, D. Pedro de Meneses, $2^{\circ}$ Conde de Alcoutim, na sua oração de 1504, marco indelével na história da pedagogia e da oratória ${ }^{35}$. Cataldo, mestre na língua latina, melhor prosador do que poeta, edita as suas Epistolae et orationes, que vêm a lume em Lisboa, nos prelos de Valentim Fernandes da Morávia, a 21 de Fevereiro de 1500 - um documento precioso para o estudo do Humanismo em Portugal.

A Cataldo se deve o primeiro manifesto, publicado em Portugal, em defesa do latim humanístico contra a barbárie estilística do latim medieval, na linha de Lourenço Valla. Este manifesto surge da pena do introdutor do Humanismo em Portugal, em carta dirigida a D. Fernando de Meneses, Marquês de Vila Real, escrita em fins de 1499 ou em janeiro/fevereiro de $1500^{36}$. Nesta epístola, ataca a barbárie medieval e certos theologiculi, 'teólogos de meia-tigela' que a defendem, e faz o louvor dos poetas e entre todos Virgílio ${ }^{37}$. Nela há ainda um pormenor a salientar: Cataldo defende a afinidade, se não mesmo a identificação, entre Retórica e Poética e faz a defesa da Poesia,

Coimbra, ${ }^{2}$ 1994: 31; A. Costa Ramalho, Estudos sobre a época do Renascimento. Lisboa, ${ }^{2} 1997$ : 83-105.

${ }^{34}$ W. Keith Percival, "Grammar and rhetoric in the Renaissance", in Renaissance eloquence, ed. J. Murphy, Berkeley, University of California Press, 1983: 303-330.

${ }^{35}$ D. Pedro de Meneses, embora ensinado pelo mestre, proferiu em 1499, com doze anos apenas, duas orações públicas em latim, segundo costume italiano, uma na Universidade de Lisboa e outra perante o rei. E aos dezassete anos encarregava-se da oração de abertura solene das aulas, na mesma Universidade, em 1 de Outubro de 1504, o primeiro discurso pronunciado numa universidade portuguesa, na presença do rei D. Manuel, que chegou até nós. Esta oração, publicada no segundo volume das Epistolae de Cataldo, mereceu uma edição moderna de A. Moreira de Sá e tradução de Miguel Pinto de Meneses. Cf supra, n. 13. Além da prestimosa ajuda do Sículo na elaboração destes discursos, teria pesado na mestria intelectual do jovem aristocrata o ambiente de sua casa, onde era proibido falar português (Vide a oração que Salvador Fernandes profere em honra de D. Fernando de Meneses, na entrada no seu marquesado de Vila Real, em 1509 (A. C. Ramalho, Latim Renascentista em Portugal - Antologia. Coimbra, ${ }^{2} 1994$ : 1994: 113).

${ }^{36}$ A. Costa Ramalho (21994), Latim Renascentista em Portugal. - Antologia. Coimbra: 41-53.

${ }^{37}$ Sobre a importância de Virgílio como paradigma de realização poética no Renascimento, vide e. g. V. Zabughin, Vergilio nel Rinascimento italiano da Dante a Torquato Tasso, Bologna, 1921. 
alegando diversas autoridades. Entre elas, figura S. Basílio Magno, autor do opúsculo intitulado, na tradução latina de Leonardo Bruni Aretino, De legendis antiquorum libris. Os autores cristãos da Patrística são assim considerados a par dos clássicos. Além disso, é aconselhada, "para inteligência da Sacra Página", a leitura dos escritores e poetas da Antiguidade pagã.

A lição dos poetas, que vai a cada passo ser seguida pelos tratadistas pedagógicos, desde o Quattrocento, é enaltecida pelos autores do primeiro humanismo italiano - tais como Boccaccio no seu De genealogia deorum, considerado já a magna charta da nova dignidade universal conquistada pelas letras, ou Coluccio Salutati, em De laboribus Herculis, ou ainda Enea Silvio Piccolomini, futuro papa Pio II, no De liberorum educatione. Era a lição de Aristóteles, que ditara a Horácio o valor didáctico, ético, filosófico e lúdico da poesia, o poder de unir utile dulci, pois aut prodesse nolunt aut delectare poetae (Hor. Ars poetica, v. 343 e 333).

D. Fernando de Meneses (1463-1524), $1^{\circ}$ conde de Alcoutim e $2^{\circ}$ marquês de Vila Real, que acolhe Cataldo e faz dele mestre de seus filhos, é bem o representante da velha nobreza, orgulhosa dos seus pergaminhos e dos seus privilégios, aberta ao saber, à cultura humanística e à educação moderna ${ }^{38}$.

Cataldo, chamado de Itália por D. João II, para educar o seu filho bastardo D. Jorge, de seis anos de idade, irá beneficiar outros rebentos da aristocracia, com o seu ensino, o que lhe valeu ser designado, na palavra de Joaquim de Carvalho, «o educador da nobreza portuguesa» ${ }^{39}$. É no seu magistério, no seu programa cultural, nos seus métodos pedagógicos de ensino directo dos autores latinos que Cataldo teve um papel decisivo na abertura de Portugal ao Humanismo.

Cataldo educara D. Jorge, em letras e em costumes, desde 1487 a 1495, ano da morte de D. João II. A esta primeira educação, a puerilis institutio, que tem por objectivo a aquisição de bons hábitos, a formação do carácter, no que respeita à moral individual e social, dão o tom Quintiliano e Plutarco, tal como os humanistas do Primeiro Humanismo italiano preceituavam e todos os pedagogos europeus do Renascimento não se cansavam de repetir. Plutarco $^{40}$ - inspirado em Platão, designadamente nas Leis e no Ménon - no

${ }^{38}$ Modelares são os estudos que dedicou a este representante da ilustre casa de Vila Real, no Renascimento, Jean Aubin, nosso saudoso mestre na École Pratique des Hautes Études de Paris. Vide Jean Aubin, Vieille noblesse et temps nouveaux. D. Fernando de Meneses, 2e marquis de Vila Real (1463-1524). Paris, 1983; Jean Aubin, "Vieille noblesse et temps nouveaux. Les amertumes du 2e marquis de Vila Real”, in: Le Latin et l'astrolabe. Études inédites sur le règne de D. Manuel 1495-1521.Éd. posthume par M. C. Flores; Luís Filipe R. Thomas; Françoise Aubin, Paris, 2006: 61-101.

${ }^{39}$ Joaquim de Carvalho (1947-1948), Estudos sobre a cultura portuguesa do séc. XVI, 2 vols. Coimbra, 1947-1948: II, p. 29 e sqq.

${ }^{40}$ Os Moralia de Plutarco são verdadeiro manancial de inspiração de educação aristocrática. 
seu tratado De liberis educandis, e ainda em opúsculos morais como An uirtus doceri possit, ou De audiendis poetis, servirá de suporte, a par de Quintiliano, à primeira educação e à formação da juventude.

Quintiliano, inspirado em Cícero, vai propor, na sua Institutio oratoria (1. 10. 6), uma ratio studiorum, adequada à aquisição da sabedoria, a enkyklios paideia, que não se destina, geralmente, a preparar especialistas, futuros pedagogos, mas a formar integralmente a pessoa humana, física, intelectual e moralmente.

É, enfim, a instrução enciclopédica que Crasso reclama no De oratore ciceroniano, e a formação moral que lhe associa Quintiliano. Numa palavra, o ideal humano que a Antiguidade greco-latina transmitira, sobretudo a partir das sínteses feitas por Cícero, Quintiliano e Plutarco, constitui a essência da mensagem pedagógica dos humanistas do Quattrocento, que perdura ao longo de todo o Renascimento, e informa um dos aspectos mais salientes do humanismo cívico, da ciuilis scientia, fundamento da vida pública ${ }^{41}$.

Neste particular, Cataldo não deixa de dar o tom. Ainda em Bolonha, Cataldo pronuncia uma Oração em louvor de todas as ciências e da própria Bolonha, editada em Epistolae I, em 1500. Serviu ela de guião, de ponto de partida, a abrir curso às que se proferiram, no século XVI, na Universidade, no Colégio das Artes e nos Colégios dos Jesuítas, apresentando a de Hilário Moreira, pronunciada na Universidade de Coimbra, em 1552, verdadeira intertextualidade com a de Cataldo ${ }^{42}$. Ao longo dos tempos, permanece inalterado o modelo ciceroniano destas orações, em que o elogio das letras segue designadamente o Pro Archia, e o ideal do homem culto, virtuoso, perito na arte de bem falar é dado pelas recém-encontradas obras retóricas de Cícero Brutus, De oratore e Orator, e pela Institutio oratoria de Quintiliano.

O programa de estudos, que estas orações preconizavam, era praticamente o mesmo, desde a oração de Cataldo à oração que D. Pedro de Meneses pronunciara, em 1504.

As disciplinas apresentadas seguem a divisão aristotélica das ciências, que se agrupam no trivium ou artes sermocinales e no quadrivium ou artes reales,

\footnotetext{
Vide, além destes opúsculos, e.g. De uita et poesi Homeri, ou Ad principem ineruditum, ou De adulatore et amico, ou ainda os Regum et imperatorum apophtegmata, as Vitae paralelae, as vidas exemplares de gregos e romanos. Nestas biografias sobressai a de Alexandre, secundada pelo opúsculo Alexandri Magni fortuna aut uirtute que são fonte de verdadeiros tópoi literários, recorrentes na tratadística pedagógica. Alexandre, educado por Aristóteles - cuja ânsia de fama e de renome adquire um valor paradigmático no Pro Archia de Cícero e na Sátira X de Juvenal -, é o modelo do guerreiro, que alia a coragem e o ideal heróico da honra à cultura.

${ }^{41}$ Nair N.Castro Soares, O principe ideal no século XVI e a obra de D. Jerónimo Osório, Coimbra, 1994: 99-188.

${ }^{42}$ Hilário Moreira (1990), A oração de sapiência de Hilário Moreira. Introdução, texto latino, tradução e notas de Albino de Almeida Matos, Coimbra, 1990.
} 
adoptando cada uma das orações uma determinada hierarquia de valores, em que é perceptível a evolução e o alargamento dos saberes, verificados no magistério universitário, ou mesmo no ensino de príncipes - como se depreende da dedicatória a D. João III do De crepusculis de Pedro Nunes, cosmógrafo, lente da Universidade e mestre na corte dos Infantes D. Luís, D. Henrique e D. Duarte ${ }^{43}$.

Dirá, com razão, Joaquim de Carvalho que no Renascimento «a designação das disciplinas só tinha de medieval o nome, porque a matéria e a didáctica com que foram ensinadas já se apresentam com o selo da modernidade» ${ }^{44}$.

E difícil, contudo, depreender com objectividade e certeza os ideais educativos de cada autor, vinculado que está a esquemas retóricos deste género oratório; é na hierarquização relativa dos saberes e na incidência maior ou menor em determinados aspectos que se pode perceber a intenção última do orador, o seu eu enunciativo, a sua forma mentis, o seu ideal pedagógico e cultural.

Pode mesmo constatar-se que, a partir da oração de André de Resende, pronunciada na Universidade de Lisboa, em 1534 - que manifesta a maior

${ }^{43}$ Datada de 27 de Outubro de 1541, a dedicatória do De crepusculis, que é porventura a obra mais notável de Ciência pura excogitada por uma mente portuguesa, no dizer de Joaquim de Carvalho - 'Pedro Nunes, mestre do Cardeal Infante D. Henrique', in $A$ cidade de Evora 21-22 (1950) 1-13, maxime p. 8 -, revela não só a inclinação natural de D. Henrique para «as ciências matemáticas» como dá a conhecer todo um programa de ensino científico que primava pela modernidade. Cf. Joaquim de Carvalho, Obras de Pedro Nunes, vol. II, Lisboa, 1943: 5: a Aritmética, os Elementos de Geometria de Euclides, a Teoria da Esfera, a Teórica dos Planetas, parte do Almajesto de Ptolomeu, a Mecânica de Aristóteles, a Cosmografia e a prática de alguns instrumentos, assim antigos como modernos, relativos estes à arte de navegar, inventados pelo próprio Pedro Nunes (quae ego ad navigandi artem excogitaueram); Ao Infante D. Henrique dedica Pedro Nunes o seu Livro de Álgebra en Aritmética y Geometria (Antuérpia, 1567), composto quando lhe ensinava as artes reales (1531-1533). Não poderemos deixar de lembrara importância das descobertas marítimas dos portugueses para o interesse e desenvolvimento do conhecimento científico, não só no domínio das ciências exactas, da geografia e das ciências da natueza, que os Colóquios dos Simples e Drogas de Garcia d'Orta admiravelmente exemplificam, quer ainda na consciencialização do valor da experiência, como suporte fundamental do saber. Vide Luís de Albuquerque, "Science et Humanisme dans la Renaissance portugaise", in L'Humanisme Portugais et l'Europe, Actes du XXI e Colloque International d'Études Humanistes (Tours, 3-13 Juillet 1978), Paris, 1984: 419-435; J. V. de Pina Martins, "Humanismo e universidade. Livros quinhentistas editados em Coimbra no âmbito dos estudos escolares e sua contribuição para o progresso do Humanismo", in Actas do Congresso sobre História da Universidade no VII Centenário, t. IV, Coimbra, 1991, p. 47-66, maxime p. 60.

${ }^{44}$ Joaquim de Carvalho, "Pedro Nunes, mestre do Cardeal Infante D. Henrique" op. cit., p. 6. Segundo a ordem que se tornou tradicional desde Alcuíno, o trivium era constituído pela Gramática (isto é, o estudo do Latim, que se alargou ao Grego e ao Hebraico e incluía a Poesia), a Dialéctica e a Retórica. Para se ajuizar do desenvolvimento e do alcance destas disciplinas, vide e. g. B. Weinberg (a cura di), Trattati di Poetica e Retorica del Cinquecento, 3 vols., Bari, 1970-1972. O quadrivium era constituído pela Aritmética, a Geometria, a Astronomia e a Música (consistindo esta última na aprendizagem do cantochão e respectiva teoria). 
elaboração individual no género e a maior desenvoltura e segurança na apresentação da matéria - todas se vinculam a verdadeiros topoi temáticos, que se exprimem pelos mesmos exempla ${ }^{45}$.

Além disso, o estilo destas orações - como as que pronunciou o humanista eborense, num elegante latim ciceroniano, a que nem faltam as cláusulas métricas, nem a linguagem, o vocabulário da preferência de Cícero — obedece desde Cataldo, a uma superlativação verdadeiramente humanística. Esta superlativação é comum ao tom encomiástico, laudatório ou panegírico de grande parte das composições desta época ${ }^{46}$.

Assim sendo, a pedagogia de André de Resende, no sentido estrito do termo, não pode ser apreciada apenas pela enumeração das artes liberales, feita no célebre discurso de 1534, pois ela surge em termos semelhantes nas orações de finais do século XV às da segunda metade do século XVI.

Apesar de tudo, a perfeição estilística e temática, revelada por Resende nesta oração, sem esquecer o vivo apelo ao cultivo do Grego, documenta bem a evolução do género e o estádio de desenvolvimento intelectual e cultural do nosso país ${ }^{47}$.

Exemplar é esta oração de 1534 precisamente na defesa da Gramática e nas críticas ao seu ensino tradicional. O ensino da Gramática, que integrava a Retórica a Dialéctica e a Poesia deveria fazer-se, como recomendava Quintiliano, a partir da leitura e interpretação dos textos clássicos, no original. Se a mestria na arte de bem falar e de bem compor, ou seja de bem escrever, era o principal objectivo da Gramática, esta incluía também o ensino do Grego, necessário e indispensável ao acesso à verdadeira cultura humanística.

As preocupações pedagógicas, nesta oração, integram-se no quadro das reformas educativas estruturais que desde o tempo de D. Manuel se faziam sentir, através dos estatutos novos conferidos à Universidade de Lisboa, à abertura de novas escolas, ao incremento cultural que procurava atingir a dignidade e a altura da grandeza do império atlântico.

Um aspecto é relevante nestas orações académicas: as proferidas antes de

${ }^{45}$ Cf. o estudo introdutório de Jorge A. Osório (1967), A oração sobre a fama da Universidade de Me. João Fernandes (1548). Prefácio, introdução e notas. Coimbra, 1967; A. Costa Ramalho, "Cícero nas orações universitárias do Renascimento", in Para a História do Humanismo em Portugal I, Coimbra, 1988: 31-47.

${ }_{46}^{46}$ Vide Jean Lecointe (1993), L'idéal et la différence. La perception de la personnalité littéraire à la Renaissance, Genève, 1993: 94-98.

${ }^{47}$ Vide J. V. de Pina Martins, "Humanismo e universidade. Livros quinhentistas editados em Coimbra no âmbito dos estudos escolares e sua contribuição para o progresso do Humanismo" op. cit., maxime, p. 60. Nicolau Clenardo, contratado para professor de Humanidades do Infante D. Henrique refere, na sua Epistola ad Christianos, que este, além do Latim pelo seu método directo, estudou Grego, Hebraico, Filosofia, Teologia e Matemática (cf. Correspondance de Nicolas Clenard, publicada por Alphonse Roersch, Bruxelas, 1940, p. 227-228). 
meados do século XVI impõem-se como verdadeiros manifestos humanistas contra a barbárie medieval, insensível à beleza e elegância clássicas, na linha das Elegantiae linguae latinae de Lourenço Valla. As posteriores têm como preocupação dominante a orientação religiosa, ou melhor, teológica, a que não são alheias as relações entre política e cultura; a definição do ideal do governante e a sua acção concreta, no aspecto educativo e administrativo, na sua acção evangelizadora, no seu empenhamento na cruzada contra o Turco, na manutenção da paz e concórdia internas ${ }^{48}$.

Um lugar de relevo, nesta oração, é dado à educação. André de Resende, pelas funções que desempenha na corte, a partir de 1533, quer como mestre de príncipes, quer como teólogo, vai ter um papel importante na nova orientação do ensino em Portugal.

No seu ardor pedagógico, o Eborense contribuiu para criar o ambiente propício às ideias reformadoras de D. João III. O rei que, com seu irmão Afonso, foi leitor de Erasmo - como sabemos pelo Erasmi encomium de Resende (vv. 207-210) — manifestou o desejo de convidar o Mestre de Roterdão para vir ensinar em Coimbra ${ }^{49}$, e encarregou Resende de trazer para Portugal os humanistas belgas Clenardo e João Vaseu, seus amigos e reputados professores do Colégio Trilingue de Lovaina.

É nesta década de trinta do século XVI que as instituições de cultura nacionais vão conhecer uma reforma por assim dizer sistemática, que corresponde ao generalizado entusiasmo europeu pelas Humanidades, a que a imprensa veio dar um notável contributo ${ }^{50}$.

${ }^{48}$ Exemplificativas são as orações de André de Resende de 1534 e de 1551 . Nesta oração, proferida na presença do Infante D. Luís, no Colégio das Artes, em Coimbra, e dedicada à Infanta D. Maria, para não ser acusado de adulação ao rei, confessa o Humanista, faz o elogio de D. João III, não em termos abstractos de doutrina política, mas em termos concretos, tomando o próprio rei como centro de reflexão. André de Resende faz o elogio de D.João III, na homenagem que o Colégio das Artes fazia anualmente ao seu fundador e, no mesmo Colégio, por ocasião da morte do rei, em 1557. Segundo Maria Manuela Barroso de Albuquerque, "André de Resende. O drama dum humanista português", Euphrosyne 1 nova série (1967) 107-134, a oração de 1551 denota já o esmorecer do fervor humanístico e renovador que Resende manifestara dezassete anos antes, na Oração de 1534. A prisão dos «bordaleses», em 1550, e o acentuar das tendências ortodoxas de inspiração tridentina no meio português, tornaram o detractor da vida áulica em servidor de príncipes.

${ }^{49} \mathrm{Cf}$. a declaração de Damião de Góis perante a Inquisição. Vide, a este propósito, Marcel Bataillon, Études sur le Portugal au temps de l'Humanisme, Coimbra, 1952: 89. A testemunhar a simpatia de Erasmo pelo possível futuro Mecenas, ficou a dedicatória a D. João III das suas Chrysostomi lucubrationes, na sua edição de 1527 , retirada em edições posteriores.

${ }^{50}$ De uma importância singular é o contributo da imprensa na pedagogia humanista. Em Coimbra, já antes de 1537, ano da transferência da Universidade, existiam os prelos de Santa Cruz: em data que se fixa entre fevereiro de 1530 e abril de 1531, Germão Galharde monta a imprensa do Mosteiro e ensina a sua arte aos Cónegos regrantes. Em 1534 aparecem pela primeira vez em Portugal os caracteres gregos, na Imprensa de Santa Cruz de Coimbra, sendo ainda escrito à mão o Grego da Oratio pro rostris de Resende, que sai a lume, em Lisboa, neste 
No estrito domínio retórico e filológico, depois das primeiras décadas de Quinhentos, em que se assiste à renovação do ensino gramatical, orientado para a aquisição da eloquência latina, a década de trinta vai assistir à consolidação do estatuto da arte oratória como disciplina autónoma, em que se impõe o método da escola renano-flamenga da pedagogia do humanismo do Norte da Europa, o modus parisiensis, que dominou no ensino da retórica em Portugal e na Europa ${ }^{51}$.

$\mathrm{Na}$ cidade do Mondego, cantada repetidamente como lusa Atenas, a reforma é liderada por dois obreiros incansáveis, ambos formados na Universidade de Lovaina, Frei Brás de Braga e Fr. Diogo de Murça. Conhecida é a abertura destas duas figuras eminentes do nosso Humanismo Renascentista às correntes de espiritualidade e da pedagogia erasmianas ${ }^{52}$. Desde 1548 , o Colégio das Artes contava com humanistas de reputação europeia, entre o seu corpo docente, como Georges Buchanan, Guillaume de Guérente, Nicolas Grouchy, Elias Vinet, Diogo de Teive e o Principal Diogo de Gouveia a quem Montaigne, aluno do Colégio da Guiena coloca acima de todos os Principais de França.

A par da Universidade de Coimbra, os Colégios universitários hieronimitas de Penha Longa e de Santa Marinha da Costa, junto de Guimarães, conhecem grande prestígio. $\mathrm{O}$ mecenatismo régio é secundado

mesmo ano. Por carta de 5 de Julho de 1539, D. João III, ciente da importância do livro como instrumento fundamental do ensino e desenvolvimento cultural da Academia, determina que "hos livreyros q na dita çidade tyverem suas temdas com copia de liuros das çiemçias q na dita vnyversidade lem guozem de todollos priujlegios \& liberdades q tem \& de q gozam os estudamtes \& offiçiães da dita vnyversidade" (Vide Mário Brandão, Documentos de D. João III, Coimbra, 1937, vol. I, p. 155-156). Por alvará de 21 de Março de 1548, o monarca confirma e aprova o contrato celebrado, por seu mandado, entre o reitor Frei Diogo de Murça e os impressores João de Barreira e João Álvares, "pera aveeree de ter inpresaõ na dita vniversidade" (Ibidem, vol. III, p. 141-142).

${ }^{51}$ Essa reforma profunda do ensino é levada a cabo pelo rei D. João III, em várias cidades do país e designadamente em Coimbra, para onde transferiu a Universidade em 1537 e onde fundou o Colégio das Artes, em 1548, que dá uma sólida preparação aos alunos que ingressam na Universidade.

${ }^{52}$ Cf. e.g. J. V. de Pina Martins, Humanisme et Renaissance de l'Italie au Portugal: les deux regards de Janus, Lisboa-Paris, 1989: 433, 436 e 566. A reforma do ensino em Santa Cruz é levada a cabo por D. Frei Brás de Braga, dez anos antes da transferência da universidade para Coimbra. À frente da Universidade está Frei Diogo de Murça, confrade e condiscípulo em Lovaina e em Paris do reformador e governador de Santa Cruz. Este jeronimita, que recebeu em 27 de maio de 1533 o «bonnet doctoral» na Universidade de Lovaina, onde conheceu Clenardo, foi o $4^{\circ}$ reitor da Universidade de Coimbra, desde 5 de novembro de 1543 a 28 de setembro de 1555, data em que o rei encarregou o Doutor Afonso do Prado de servir de Reitor (cf. Mário Brandão, Documentos de D. João III, Coimbra, vol. IV, 1941: 260). Ilustrativa dos interesses culturais de Frei Diogo de Murça é a relação dos livros que integravam a sua biblioteca — obras dos autores clássicos, dos autores sagrados, de humanistas italianos famosos do Quattrocento ao Cinquecento, do humanismo hispânico e europeu, numa abrangência temática e ideológica verdadeiramente notáveis (Vide A. Moreira de Sá, Livros de uso de Frei Diogo de Murça, Coimbra, 1977). 
pelo de outras figuras, como o cardeal Infante D. Henrique, que protege o Colégio de S. Paulo em Braga, onde é Arcebispo. Neste colégio ensina Clenardo cerca de um ano os rudimentos da língua latina, enquanto Vaseu não chega de Salamanca. Clenardo fica mais ligado à pessoa do Cardeal, João Vaseu é nomeado para a cadeira de Retórica ${ }^{53}$. Transferido D. Henrique para a mitra de Évora, os humanistas belgas acompanham-no. A capital alentejana beneficiaria agora da sua acção pedagógica, que se vinha juntar à de André de Resende ${ }^{54}$.

Era o Humanismo português que se afirmava, em estreita ligação com a vizinha Espanha, desde os seus inícios. A familiaridade entre as cortes ibéricas, em que as princesas espanholas se tornavam rainhas em Portugal, a presença de humanistas espanhóis na corte - como capelães, confessores e mestres de príncipes - nos colégios e na universidade, a permeabilidade de métodos e compêndios, a mobilidade de mestres e alunos pelas diferentes instituições contribuíram para a formação de uma comunidade cultural que, sem perder as marcas da sua identidade própria, se pode designar por Humanismo Ibérico.

Muitos humanistas portugueses estudaram em Salamanca, muitos deles foram mestres na cidade do Tormes. Portugueses e espanhóis foram opositores às mesmas cátedras aquém e além-fronteiras. O Colégio Trilingue de Alcalá de Henares, fundado pelo Cardeal Cisneros, será frequentado por portugueses, a par do de Lovaina e do de França, que abrirão caminho ao Colégio das Artes, em Portugal. Se a Universidade de Salamanca teve, no primeiro Humanismo, entre os seus mestres de renome, o espanhol António de Nebrija e o humanista de Aveiro Aires Barbosa, a nossa Universidade contou com a presença tutelar do canonista Martin de Azpilcueta Navarro e de Juan Fernández, o editor dos Colloquia de Erasmo para o ensino do Latim. As universidades de Salamanca e as de Itália, que têm a preferência dos portugueses durante o século XV, vão cedendo lugar, embora não completamente, no século XVI, a Lovaina e às universidades francesas.

Se é verdade que a mensagem pedagógica dos humanistas do Quattrocento italiano perdura ao longo de todo o Renascimento europeu,

${ }^{53}$ Com a intenção de suprir às necessidades dos alunos, publica Vaseu, ainda em Salamanca, donde se deslocara, uma Collectanea Rhetorices, em 1538, com um prefácio-dedicatória ao Cardeal Infante D. Henrique. O exemplar existente na Biblioteca Municipal do Porto figura numa encadernação conjunta com a gramática latina de Clenardo.

${ }^{54}$ Em Évora, exerceram o seu magistério junto de príncipes e nobres ou em escolas públicas, André de Resende, Clenardo, Vaseu e Diogo Sigeu. Diogo Sigeu de Toledo veio para Portugal em 1543 e foi, na corte, além de secretário da correspondência latina, mestre de retórica do Príncipe João e outros moços fidalgos, entre os quais avultam D. Teodósio de Bragança e seus irmãos. Vide, sobre Diogo Sigeu e suas filhas, Carolina Michaëlis de Vasconcelos, A Infanta D. Maria de Portugal (1521-1577) e as suas damas. Prefácio de A. Costa Ramalho. Edição fac-similada, Lisboa, 1994: 38-42. 
contudo, grande é a distância que separa o primeiro humanismo do do período áureo, pois bem diverso é o contexto cultural, social e político, determinante das suas diferenças essenciais. Estas dizem respeito designadamente ao aprofundamento do saber filológico, que cada vez mais se afasta da "barbárie medieval”, à evolução e aperfeiçoamento dos cânones estéticos, à maior importância dada ao conhecimento do grego e da literatura grega e também do hebraico - que notabilizaram os Colégios Trilingues de Alcalá de Henares e de Lovaina, o Colégio Real de França, fundado por Francisco I, sob a inspiração de Guillaume Budé, a Universidade de Coimbra e todas as instituições europeias de prestígio, no século XVI.

Numa palavra, desde o primeiro Humanismo em Portugal, como na Espanha e na Europa, o processo formativo do homem, a sua educação integral, privilegiava a componente retórica, indispensável à capacidade oratória, à arte da palavra do homo urbanus, que se distinguia pela nobilitas morum, pela cultura, pelo trato e gostos elegantes, tal como preceituava, em finais do Quattrocento, Giovanni Pontano no De sermone libri sex.

Texto inaugural na reflexão europeia sobre a força civilizadora da palavra, sobre a arte da conversação, como fenómeno ético e estético, o humanista da corte aragonesa de Nápoles - também ele autor de um diálogo retórico, Actius, sobre o estilo em prosa e em verso - propõe no De sermone o ideal de homem urbano e cortesão, instruído e agradável, vir doctus et facetus, e aponta como estratégia o paciente trabalho de reeducação civil, através da prática viva dos valores da cultura humanística, suporte do modelo do "vivere civile".

Este discurso pedagógico de Giovanni Pontano não se cinge apenas à esfera privada e ao culto da personalidade individual, mas tem um alcance muito mais vasto, ao ter como objectivo primeiro dar regras de conduta à sociedade aristocrática, trasformando o cavaleiro feudal em "gentiluomo" moderno. Este discurso arquetípico anuncia já os temas desenvolvidos pelos três grandes livros do modelo italiano de urbanidade, Il Libro del Cortegiano di Baldassarre Castiglione (1528), Il Galateo (1558) di Giovanni Della Casa e La Civil conversazione (1574) di Stefano Guazzo ${ }^{55}$.

$\mathrm{O}$ sentido da urbanitas que as humaniores litterae conferem é também entre nós, no Renascimento, posto ao serviço dos anseios cortesanescos de grande número de letrados e de membros da fidalguia. O jogo de forças políticas no interior do estado e sua implicação com o ideal cortesanesco, vivido por mais de um século na sociedade portuguesa, vai favorecer a ambição, a inveja, a adulação e a hipocrisia da corte, que é retratada e criticada em profusão nas obras do nosso século de ouro, desde a tratadística pedagógica e filosóficomoral, às diferentes formas de poesia, à arte dramática.

\footnotetext{
${ }^{55}$ Baldassare Castiglione, Il Cortigiano, a cura di Amedeo Quondam. Milano, 2002.
} 
No tempo de D. Manuel (1495-1521) chega-se ao epílogo da longa história de descobrir. Vive-se o fausto e o luxo da corte mais prestigiada da Europa, que sustenta a ociosidade e a mania nobiliárquica dos cortesãos, numa Lisboa exótica e cosmopolita ${ }^{56}$. Os Jerónimos e a Torre de Belém tornamse símbolos da grandeza do império e impõem um estilo arquitectónico que recebeu a designação de "manuelino". Os serões do paço são animados pelo teatro de Gil Vicente - que a rainha D. Leonor, viúva de D. João II, protegia -, pela poesia palaciana, pela música, em que D. Manuel era aficcionado, pela cultura das artes e das letras. Até aos moços negros da corte mandava o rei ensinar a Gramática.

A corte, sentida como meio ideal para a realização das virtudes humanas, a que deu viva voz Garcia de Resende, no "Prólogo" ao Cancioneiro Geral, publicado em 1516, requer "cavalleros blandos i enseñados", no dizer de Sá de Miranda, na dedicatória do Epitalâmio pastoril a António de Sá no casamento de sua flha ${ }^{57}$. Era a ilustração viva dos ideais proclamados por Il cortegiano (1528), obra dedicada a D. Miguel da Silva, considerado por Baldassare Castiglione modelo de urbanidade ${ }^{58}$. Boscán depressa a divulgará em língua castelhana.

A retórica de corte, em todas as suas vertentes, complementares entre si, pedagógica e civil, literária e artística, imprime uma singular especificidade ao discurso do Primeiro Humanismo Português, que se traduz no ideal de realização plena do humano, próprio da educação moderna, e se assume como expressão de identidade de um povo de vocação universal, ao tempo das Descobertas.

O ideal humano que a Antiguidade greco-latina transmitira, sobretudo a partir das sínteses feitas por Cícero, Quintiliano e Plutarco, constitui um dos aspectos mais salientes do humanismo cívico, da ciuilis scientia, fundamento da vida pública, e é por isso também a essência da mensagem pedagógica e retórica que, desde os humanistas do Quattrocento italiano, perdura ao longo de todo o Renascimento, em Portugal e em Espanha.

${ }^{56}$ As fontes de riqueza, que sustentavam canais de consumo e não de investimento, o abandono da agricultura, a expulsão dos judeus e o seu massacre em Lisboa, em 1506, iriam contribuir a passos largos para a descapitalização interna, verificada nos reinados de D. João III, que teve de abandonar as praças de Âfrica e, de forma dramática, no reinado de D. Sebastião. O tratado De regis institutione et disciplina de D. Jerónimo Osório (1572) denuncia de forma insistente esta realidade, e.g. Hieronymi Osori Lusitani, Episcopi Algarbiensis, Opera omnia. Romae. Ex Bibliotheca Georgij Ferrarij, MDXCII: I. 528.20 -530. 30.

${ }^{57}$ Veja-se a dedicatória do Epitalâmio pastoril a António de Sá no casamento de sua filha, in Poesias de Francico de Sá de Miranda. Edição feita sobre cinco manuscriptos ineditos e todas as edições impressas, acompanhada de um estudo sobre o Poeta, variantes, notas, glossário e um retrato por Carolina Michaëlis de Vasconcelos (1885) Halle: 501, onde se encontra o passo citado; vide ainda, a este propósito, a carta de António Pereira Marramaque a Diogo de Castro, referida por Eugenio Asensio, Estudios Portugueses. Paris, 1974: 168.

${ }^{58}$ Vide Sylvie Deswarte, Il 'perfetto cortegiano' D. Miguel da Silva. Roma, 1989. 
Eugenio Garin, o conceituado estudioso do Humanismo Renascentista, interrogado pela revista Panorama, afirmava: «Se dovessi dire nel modo piu semplice qual è il vero elemento centrale della cultura rinascimentale, direi che è la scoperta del valore della diversità ${ }^{59}$.

Pode afirmar-se, contudo, que, apesar do assumir da diferença, da diversidade, a nível individual e colectivo se torna princípio unificador deste movimento cultural a crença no valor do homem e nas humanidades, no ressurgir do mundo antigo, de que a retórica se tornou um instrumento privilegiado.

É que, apesar do já designado "individualismo" renascentista, um traço comum de inspiração ciceroniana preside ao ideal pedagógico da formação humana, desde o Quattrocento italiano: a síntese da filosofia e da retórica, a combinação da eloquência e da sabedoria ${ }^{60}$. Neste ideal se irmanam humanistas europeus, da Inglaterra à Alemanha, aos Países Baixos, à França e à Hispânia, um John Colet, um Rodolfo Agrícola e um Erasmo, um Lefèvbre d' Étaples, um Budé, um Luís Vives e um Aires Barbosa, para falar apenas de nomes representativos do primeiro Humanismo.

${ }^{59}$ Vide o artigo "Radici ideali/ L'attualità del Rinascimento - Cinquecento siamo noi", in Panorama, no1174, Anno XXVI (16 de Outubro 1988): 124-131. Passo citado: 129.

${ }^{60}$ Vide Alain Michel, La philosophie politique à Rome d'Auguste à Marc-Aurèle. Paris, 1969. Idem, Les rapports de la rhétorique et la philosophie dans l'oeuvre de Cicéron: recherches sur les fondements philosophiques de l'art de persuader. Paris, 1960. 


\section{Aires Barbosa \\ E L'ESPERIENZA POETICA DELL'UMANESIMO ITALIANO}

Italo Pantani

“La Sapienza”, Università di Roma

Due evidenti, e già note costanti è dato rinvenire nella prestigiosa attività culturale di Aires Barbosa, tanto nei ventotto anni dell'insegnamento nell'Università di Salamanca (1495-1523), quanto nei sette trascorsi presso la corte reale portoghese come precettore del giovanissimo cardinale Alfonso (1523-1530), quanto infine negli ultimi dieci passati nel ritiro del suo paese natale (1530-1540): una coerente dedizione ai principi della dottrina cattolica, e la centralità pressoché assoluta assegnata alla poesia, tanto come materia di studio e insegnamento, quanto come pratica creativa. Lo comprova la massima parte delle opere da lui pubblicate: le due relectiones metricologiche, l'Epometria (1515) e la Prosodia (1517), quest'ultima accompagnata da 36 epigrammi; il corso accademico (1513-1514) e l'ampio commento (1516) dedicati all'Historia Apostolica, il poema epico di Aratore d'argomento neotestamentario; e il carme teologico Antimoria, edito nel 1536 a Coimbra, con appendice di 50 epigrammi ${ }^{1}$. Del resto, è lo stesso umanista a esplicitare e motivare tale predilezione, in un passo dell'Epometria già citato da Sebastião Pinho:

Soleo, auditores suavissimi, poetas vobis libentius quam historicos vel oratores interpretari: non quod hos inutiles incipientibus arbitrer [...], sed quia, in tanta apud nostros homines linguae latinae incuria, magis necessarium carmen vobis quam prosam orationem multoque esse utilius puto. Sive enim ratio honeste vivendi, sive optime discendi a vobis petatur, utrumque facilius a vatum quam ab oratorum fontibus haurietis ${ }^{2}$.

${ }^{1}$ Per un quadro dell'attività poetica di Barbosa, cf. Sebastião Tavares de Pinho, Humanismo em Portugal. Estudos I. Lisboa, Imprensa Nacional - Casa da Moeda, 2006: 97-114 ("Aires Barbosa, pedagogo e poeta"); sul ruolo assegnato alla poesia dall'umanista portoghese cf. ibid.: 129-147 ("Retórica e poética na Epometria de Aires Barbosa"), in particolare: 132-133. Riguardo a vita e opere dell'autore, cf. José Henrique Rodrigues Manso, Comentário de Aires Barbosa ao segundo livro da Historia Apostolica de Arátor. Lisboa, Fundação Calouste Gulbenkian, 2011: 28-49, e bibliografia ivi citata. Proprio il gentilissimo collega J.H. Rodrigues Manso desidero qui ringraziare, poiché solo grazie alla sua cortese disponibilità ho potuto consultare bibliografia e testi, di pertinenza barbosiana, altrimenti per me inaccessibili.

${ }^{2}$ Arii Barbosae Lusitani Relectio, cui titulus Epometria. Salmanticae, [Juan de Porras] 1515: Aiv (cf. Pinho, Humanismo em Portugal... op. cit.: 132). 
Per il nostro umanista, dunque, lo studio dei testi poetici si fa preferire a quello delle opere in prosa, in quanto miglior veicolo sia all'acquisizione di nuove conoscenze, sia alla conquista di un onesto stile di vita. Più in generale, la scrittura poetica e la sua interpretazione sono così riconosciute come i più efficaci strumenti di elaborazione e trasmissione culturale, sui diversi piani della lingua, della scienza, dell'etica.

Questa gerarchia pedagogico-letteraria barbosiana, per essere compresa nei suoi rapporti con le speculazioni dell'Umanesimo italiano, richiede innanzitutto che si sgombri il campo da un retaggio di pregiudizi negativi duro a morire, circa il ruolo svolto dalla poesia nella cultura italiana, tra Petrarca e Poliziano. Senza risalire alle preclusioni di origine romantica o a quelle estetiche di un Croce, l'incomprensione del fenomeno si trova confermata in un famoso saggio di Carlo Dionisotti, secondo il quale "bisogna rassegnarsi alla constatazione di fatto che senza poesia è il secolo tutto [...], non l'una piuttosto che l'altra lingua"; perfino la generazione di autori come Strozzi, Pontano, Campano, attiva a partire dagli anni '40 (e in realtà tutt'altro che priva di precursori), non avrebbe rappresentato che un'“acerba primavera poetica", che "poté aprirsi a un'età che era stata deserta dalla poesia, in quanto alla stessa data quella stessa età aveva nella prosa affermato per sempre la conquista d'una nuova filologia e d'una nuova storiografia"3. Poiché invece l'età indicata era stata fin troppo feconda di poeti, molti dei quali di notevole seppur misconosciuto valore, un semplice rovesciamento di prospettiva potrebbe legittimare il sospetto che una così persistente svalutazione sia stata favorita, paradossalmente, dallo straordinario successo riscosso dal Rinascimento italiano non tanto presso i critici letterari, quanto presso storici della cultura, del pensiero e delle arti. Da Burckhardt a Baron, da Garin a Kristeller e oltre, la lente degli osservatori si è infatti sempre soffermata, alla ricerca dei fondamenti storici e ideologici del movimento, sulla vigorosa trattatistica dei vari Salutati, Bruni, Biondo, Alberti, Valla, Ficino, Pico; e se opere più propriamente letterarie hanno attirato nuove attenzioni, magari come testimonianze delle voci meno ottimiste di questa cultura, a beneficiarne, non a caso, sono stati ancora generi prosastici, quali l'apologo o il dialogo lucianeo (dalle Intercenales dell'Alberti al Charon del Pontano, antesignani dell'erasmiano Moriae encomium).

Per fortuna, il panorama critico va seppur lentamente cambiando. Il "non secondario contributo" dato dalla poesia alla formazione della cultura umanistica è stato ad esempio rivendicato da Francesco Bausi ${ }^{4}$; ed anche Francisco Rico

${ }^{3}$ Cf. Carlo Dionisotti, Geografia e storia della letteratura italiana. Torino, Einaudi, 1967: 179199 ("Discorso sull'umanesimo italiano") in particolare 185-188.

${ }^{4}$ Cf. "Modi e forme della poesia umanistica (tra latino e volgare)", in G. Rizzo (ed.), 
è giunto a riconoscere che "per gli umanisti la centralità della letteratura non fu solo una teoria del sapere ma, prima ancora, un'esperienza estetica personale [...]. Se Petrarca, Cola di Rienzo, Lovato Lovati, non avessero vibrato di tale passione di artisti, l'Umanesimo non sarebbe mai venuto alla luce"5. Molta strada, tuttavia, resta ancora da compiere. Anche in quest'ultima ricostruzione del "sogno dell'Umanesimo", i documenti di riferimento sono ancora desunti dalla trattatistica sempre citata, mentre alla scrittura poetica non è rivolta alcuna attenzione, se non per qualche rapido accenno al prestigio sociale che il potere poteva derivarne. Il pur ampio spazio riservato a uno straordinario poeta trilingue come Poliziano, maestro del nostro Barbosa, è di fatto interamente dedicato ai Miscellanea, la summa dell'Ambrogini filologo: per dimostrare, oltretutto, che col suo specialistico approccio ai nodi più complessi della critica testuale, Poliziano sancirebbe "l'avvenuto smembramento dell'ideale umanistico del sapere", nonché il ripiegarsi "su se stessa, in una nicchia professorale e professionale", della tradizione storica dell'umanesimo italiano ${ }^{6}$.

Non è questa la sede per argomentare il mio dissenso circa tale interpretazione storica, incurante dei capolavori letterari della generazione del Poliziano (grazie ai quali la passione per le lettere si trasmise a quella successiva, cui appartenne lo stesso Barbosa), e del dibattito sviluppatosi in Italia intorno alla questione del rapporto tra latino e volgare: premessa non al ridimensionamento erudito di metodo e obiettivi del movimento umanistico, ma alla riaffermazione di questi ultimi attraverso i nuovi strumenti espressivi delle lingue nazionali ${ }^{7}$. Per tornare al nostro tema, accertati i limiti e la provvisorietà delle attuali conoscenze, converrà piuttosto riavviare la ricerca dal

L'identità nazionale nella cultura letteraria italiana, Atti del III Congresso nazionale dell'ADI, Associazione degli italianisti italiani (Lecce-Otranto, 20-22 settembre 1999). Galatina, Congedo, tomo 1, 2001: 89-96 in particolare 89.

${ }^{5}$ Cf. Francisco Rico, Il sogno dell'Umanesimo (ed. or. Madrid 1993). Torino, Einaudi, 1998 : 17-18.

${ }^{6}$ Ibid.: 71-74. Non a caso, sempre Rico ("Nebrija, Aires Barbosa et l'Humanisme de leur temps", in L'bumanisme portugais et l'Europe, Actes du XXI Colloque International d'Etudes Humanistes. Paris, Fondation Caluoste Gulbenkian - Centre culturel portugais, 1984: 245-246) dello stesso Barbosa non prende in considerazione se non l'attività di filologo.

${ }^{7}$ Quando infatti si riconobbe che la "grammatica" non era peculiarità del latino, ma struttura profonda della lingua riscontrabile anche nell'idioma materno, fatalmente in Italia quest'ultimo affiancò il latino come lingua di cultura: riconosciuta come "classica", in quanto regolata da norme fondate sull'applicazione dell'umanistico principio d'imitazione. Del resto, a tale approdo contribuì fortemente il fitto e continuo dialogo intertestuale che gli scrittori quattro-cinquecenteschi intrecciarono non solo con l'antichità, o con intramontabili autorità medievali, ma anche con un vasto coro di voci coeve, appartenenti a entrambi gli orizzonti linguistici: dialogo in minima parte finora indagato rispetto alle dimensioni del fenomeno, e al quale ho rivolto la mia attenzione in vari studi, tra cui mi permetto qui di citare «La fonte d'ogni eloquenzia». Il canzoniere petrarchesco nella cultura poetica del Quattrocento ferrarese. Roma, Bulzoni, 2002. 
ruolo che alla poesia assegnarono i diretti interessati; in questa sede partendo, naturalmente, dalle posizioni assunte in merito dallo stesso Barbosa, come quelle inserite nella Praefatio al suo carme Antimoria:

Quae dignior, quae uberior actio homini facundo dari potest [...] tractanda, quam ea quae pro Sapientia pugnans Iesum laudet, et Insaniam oppugnans a vitiis absterreat? [...]. Quamvis enim Moriae encomium summa cum delectatione ab eruditis legatur, intelligentibus scilicet leporem illum suavissimum ipsis innoxium, tamen ab aliis, quae turba maxima est, non sine noxa legi potest [...]. Erasmus undanti solutae vocis eloquio qua libitum est illi digredi excurrit; nobis placuit prudentium imitari carmen scribentibus, qui pedum numeris astricti libere divagari non possumus [...]. Tamen expetivimus Christo Optimo Maximo officii genere aliquo placere et in hoc secessu tenui avena sylvestrem musam, id est inconditos versiculos meditari ${ }^{8}$.

Consapevole della propria inferiore eloquenza, non per questo Barbosa si presenta meno combattivo nel voler riaffermare, con mezzi letterari, i valori assoluti della Sapienza cristiana: virtù divina, antitetica a quella Follia così ambiguamente lodata da Erasmo. Si trattava, in realtà, di una missione costante della sua attività letteraria, già indicata nella Praefatio al suo Commento del libro I dell'Historia apostolica di Aratore:

Denique ut enarres eum poetam obsecramus, cuius sacrum carmen non tandem ad ingenni cultum, verum etiam ad pietatem veramque sapientiam pertineat [...]. Cunctos ad pietatem instruit et theoseuiam (sic), quae hominis est (ut tolerantissimus heros Iob retulit) Sapientia?.

Nella Praefatio al carme Antimoria, ben attento alle implicazioni sottese alla scelta del genere, Barbosa sostiene inoltre l'opportunità di affidarsi non alla sregolata "favola in prosa" (lucianea) del suo antagonista, ma all'equilibrio proprio della poesia: nemica delle divagazioni grazie ai freni del metro, e qui connotata come silvestre, umile, e dunque più adatta a quella maxima turba cui

${ }^{8}$ Il testo, dopo la princeps Arii Barbosae Lusitani Antimoria. Eiusdem nonnulla Epigrammata. Conimbriae, apud Coenobium divae Crucis, 1536, è stato pubblicato e tradotto da José Pereira Tavares, "Tradução do poema Antimoria e dalguns epigramas de Aires Barbosa", in Arquivo do distrito de Aveiro, 26 (1960) 9-82, da cui si cita (: 26, 28); riscontrandolo comunque con l'ed. antica (: IVv, vv-VIr), e tenendo conto della revisione di José V. de Pina Martins, Humanismo e erasmismo na cultura portuguesa do século XVI. Estudos e textos. Paris, Fundação Calouste Gulbenkian - Centro Cultural Português, 1973: 197-220.

${ }^{9}$ Aratoris cardinalis Historia apostolica cum commentariis Arii Barbosae Lusitani. Salmanticae, in aedibus Ioannis de Porris, 1516: c. Aiir. Soffermando la propria attenzione sul concetto di pietas, e rilevando le affinità con la poesia bucolica di Battista Spagnoli (il Mantovano), citò già il passo Jorge Alves Osório, O humanismo português e Erasmo, Dissertação de doutoramento. Porto, Faculdade de Letras da Universidade do Porto, 1978, tomo I: 54. 
l'equivoca ironia erasmiana risulterebbe assai pericolosa. In realtà poi il carme, incentrato sul grandioso contrasto tra l'azione perniciosa di Moria (scesa tra gli uomini a guidare l'esercito dei vizi) e quella civilizzatrice e salvifica della Sapienza divina, potrebbe effettivamente apparire lucretianae phraseos foeliciter aemulum, com'è definito nell'elogiativa prefazione da Jorge Coelho ${ }^{10}$. Più propriamente tuttavia, data la brevità dei contenuti e la programmatica sobrietà della forma (minimo ad esempio è il ricorso a riferimenti mitologici), il carme di Barbosa sembra piuttosto assumere i caratteri di una selva, il genere poetico recentemente rilanciato, non a caso, dalle quattro grandi prove del Poliziano ${ }^{11}$.

Proprio come in quest'ultime, di tale duttile genere l'Antimoria offre infatti un'interpretazione etico-didattica, che è particolarmente interessante riscontrare in alcuni versi:

\section{Non bic lascivos iuvenum cantamus amores aut Graiis nocuit quantum implacatus Achilles, Moria sed quantum noceat mortalibus una (vv. 88-90). \\ Moria mortales animos sic turbat, ut id quod est verum estque bonum, quamvis videantque probentque, deteriora sequi impellat [...] (vv. 177-179). \\ O Corydon, Corydon, coeli mysteria nescis, et Domini ignoras super omnia tempora vitam (vv. 370-371)12.}

Troviamo qui esplicitati alcuni punti strategici della poetica di Aires Barbosa. In primo luogo, si evidenzia il rifiuto della lasciva tematica amorosa (espresso con abile rovesciamento di un verso di Marziale) ${ }^{13}$, che ben si sposa

${ }^{10}$ Cf. Tavares, "Tradução do poema Antimoria...” op. cit.: 22 (Arii Barbosae Lusitani Antimoria..." op. cit: Iv). Altro letterato, Jorge Coelho, molto sensibile ai temi della fede, se di lì a quattro anni pubblicherà a sua volta un poemetto esametrico De patientia christiana, accompagnato da una Lamentatio divae Mariae Magdalenae (cf. Jorge Coelho, De patientia christiana liber unus. Item nonnulla alia quae in fine videbis. Lisboa, apud Ludovicum Rothorigum, 1540: cc. $3 r-16 r$ e $16 v-18 r$ ).

${ }^{11}$ Uscite a stampa tra il 1482 e il 1491, e oggi disponibili nell'ottima edizione (Angelo Poliziano, Silvae, a cura di F. Bausi. Firenze, Olschki, 1996). Riguardo ai rapporti intrattenuti dal Poliziano con i suoi numerosi allievi portoghesi, e con lo stesso re D. João II, rimando a Vincenzo Fera, Una ignota expositio Suetoni del Poliziano. Messina, Centro di studi umanistici, 1983: 17-22 (segnalatomi dalla prof.ssa Rita Marnoto, che ringrazio) e a Rita Biscetti, "La gloria dei Portoghesi: ancora sull'epistola di Poliziano a D. João II”, in Humanitas, 43-44 (19911992): 291-303.

${ }^{12}$ Vd. Tavares, “Tradução do poema Antimoria...”, op. cit.: 38, 42, 50 (Arii Barbosae Lusitani Antimoria... op. cit.: IXv, XIIr, XVIIr).

${ }^{13}$ Cf. Mart. Epigr. 14. 187. 1: Hac primum iuvenum lascivos lusit amores. Anche la clausola del v. 88 richiama formule classiche, soprattutto ovidiane (Rem. 379: cantet amores; Epist. 15. 155: cantat amores; Epist. 16. 257: cantabam ... amores), poi riprese soprattutto da Nemesiano (cf. Ecl. 4. 3: cantabat amores); ma un precedente identico c'è solo in Boccaccio (Egl.13.131) e in Gabriele Altilio (Carm. 1. 59). Per le edizioni di riferimento tanto degli autori classici quanto di quelli 
con la successiva identificazione del morus (vv. 178-179) nel tipo umano consapevole del bene, ma incapace di opporsi alla tentazione (prevalentemente, per l'appunto, di natura erotica): tipo umano il cui archetipo era stata la Medea ovidiana (Met. 7.20-21: video meliora proboque / deteriora sequor), ma che si era ormai ben più esemplarmente riproposto nei versi di Francesco Petrarca (Rvf 264, 136: “et veggio 'l meglio, et al peggior m'appiglio"), per poi riverberarsi tra i già numerosi emuli di quest'ultimo, nell'affollato panorama della poesia italiana, non solo volgare: notevoli in particolare le riprese di due poeti latini che vedremo importanti nella formazione di Aires Barbosa, il ferrarese Tito Vespasiano Strozzi (Eroticon 1. 8. 56: Optima cum videam, deteriora sequar) e il fiorentino Ugolino Verino (Flametta 2. 22. 43: Et meliora vident et deteriora sequuntur $)^{14}$. In secondo luogo, l'accostamento citazionale del morus al virgiliano pastore Coridone (Ecl. 2. 69: A, Corydon, Corydon, quae te dementia cepit'), un personaggio ancora una volta "folle d'amore", vale a confermare, seppur con accenno isolato, la connotazione silvestre (e dunque umile) di questo canto, come preannunciava, con altrettanto vistosa ripresa virgiliana (Ecl. 1. 2: silvestrem tenui musam meditaris avena), il già ricordato passaggio prefatorio (expetivimus [...] tenui avena sylvestrem musam, id est inconditos versiculos meditari).

Se Aires Barbosa rivela di saper abilmente ricorrere, per dichiarare la propria poetica, a locuzioni elaborate dalla latinità classica, non meno attento egli si mostra nei confronti dei più importanti poeti dell'umanesimo italiano. Pur all'interno di un verso (89) quasi interamente estrapolato da Orazio (Epist. 2.2.42: Iratus Grais quantum nocuisset Achilles), risalta ad esempio l'inserimento di implacatus, un aggettivo raro nel latino classico (una occorrenza al femminile in Virgilio e Ovidio), e declinato al maschile, anche tra i poeti umanisti, dal solo Poliziano, e proprio in quei Nutricia (Silve 4. 116) che vedremo capaci di incidere un segno profondo nella poetica barbosiana. Inoltre, se la clausola del v. 90 (mortalibus una) è prettamente lucreziana (cf. Rer. nat. 2. 919), essa si fonde nel secondo emistichio con una formula (noceat mortalibus) che non ha altri precedenti se non in Battista Spagnoli (Sylvae 2. 5. 3: Sive quod aetherei noceant mortalibus ignes), altro poeta italiano di cui è già stato notato il forte

rinascimentali, rimando all'archivio digitale di cui mi sono servito per il reperimento dei riscontri: Musisque deoque. Un archivio digitale di poesia latina (www.mqdq.it/mqdq/index.jsp); e Poeti d'Italia in lingua latina, tra Medioevo e Rinascimento (www.mqdq.it/mqdq/poetiditalia/index.jsp).

${ }^{14}$ Entrambi gli autori inserirono l'espressione nei loro canzonieri amorosi; lo Strozzi, in particolare, l'adottò in un'elegia risalente agli anni 1447-50 (cf. Anita Della Guardia, Tito Vespasiano Strozzi. Poesie latine tratte dall'Aldina e confrontate coi Codici. Modena, Blondi \& Parmeggiani, 1916: 20), su cui tornerò. I Rerum vulgarium fragmenta (= Rvf) si citano dall'edizione di Petrarca, Canzoniere. Rerum vulgarium fragmenta, a cura di R. Bettarini. Torino, Einaudi, 2005. 
influsso sull'ispirazione religiosa di tanti carmi di Barbosa ${ }^{15}$. Al v. 175 , il sintagma Mortales animos può ricordarne di simili in Orazio (Sat. 2. 6. 94: mortales animas) e Silio Italico (Pun. 2. 316: mortale animi), ma più da vicino (anche per il contesto) esso richiama il v. 253 di una famosa e già citata elegia di Tito Strozzi (Eroticon 1. 8: Mortales animos in scelus omne trabit), su cui non a caso dovremo tornare. Priva di precedenti classici è, al v. 370, l'espressione coeli mysteria, che a termini solo invertiti figurava nel solito Tito Strozzi (Borsias 4. 132: mysteria coeli) e in Ugolino Verino (Carlias 8. 862), il quale peraltro l'aveva utilizzata anche con identica successione verbale, ma significato capovolto (Carlias, App. 1.298 e 1.958: celi et mysteria nosces) ${ }^{16}$.

Tali aspetti del carme Antimoria si ripresentano perfettamente nella silloge di epigrammi che accompagna il poemetto (e più in generale nella complessiva produzione in versi dell'autore $)^{17}$. L'amore vi è escluso, se si eccettua la lode di quello coniugale nella triste occasione dell'Epitaphium uxoris: per comporre il quale di nuovo Barbosa si rivela padrone di un'ampia cultura poetica, come mostrano memorie tanto antiche (Lucano, Silio Italico, Stazio, Giovenale, Ausonio, Prudenzio: con tutta polizianea attenzione per l'età argentea e tardoantica) quanto moderne (Pontano, Verino) ${ }^{18}$. Varie deplorazioni, viceversa, sono rivolte a Issa, una fanciulla dai costumi sfrontati. I testi più ambiziosi sono d'argomento politico: alcuni seguono la rivolta delle Comunidades di Castiglia (1520-1521), con sguardo dapprima favorevole (finché essa pare avere come obiettivo la politica di Carlo V) poi contrario (quando assume caratteri antiaristocratici); altri inneggiano alle

${ }^{15} \mathrm{Cf}$. Osorio, O bumanismo português... op. cit.: 54-56.

${ }^{16}$ Tempora vitam, a sua volta, è clausola assente nel latino antico, mentre vanta occorrenze nei duecenteschi J. Stefaneschi (due) e A. Mussato, nonché nei quattrocenteschi M. Andronico e F. Andrelino. Tuttavia sulla formula barbosiana può aver influito l'affine tempora vitae, al contrario molto frequente nella classicità (attestazioni in Virgilio, Ovidio, Manilio, Seneca, Lucano, Stazio, ecc.) come nella poesia umanistica (Petrarca, Basinio da Parma, Tito Strozzi, Braccesi, Pontano, Verino, Spagnoli, Poliziano, ecc.).

${ }^{17}$ Per una puntuale illustrazione di queste tematiche, cf. Pinho, O humanismo português... op. cit.: 109-112. Oltre al carme Antimoria, diversi degli epigrammi qui ricordati sono stati èditi modernamente e tradotti da Tavares, "Tradução do poema Antimoria... " op. cit.: 68-77.

${ }^{18}$ Questo il testo: Hic iacet Elisabet generosae stirpis, et uxor / Barvosae. Moriens morte beata fuit: / nam bene quae vixit, fatali molliter hora / castam animam coelo reddidit, ossa solo. / Est igitur foelix: nullum facunda Solonis / foelicem ante obitum dicere vox solita est. / Rapta licet fuerit nimium florentibus annis, / te patrem quino pignore fecit, Ari (Tavares, "Tradução do poema Antimoria..." op. cit.: 68-69; Arii Barbosae Lusitani Antimoria... op. cit.: xxvinr). I modelli, nel dettaglio, 1 generosae stirpis: Prud. Symm. 1. 176; 2 beata fuit: Pontano De am. coniug. 2. 7. 30; 3 fatali hora: Lucan. Phars. 9. 87, Stat. Theb. 8. 185, Verino Carlias 8. 506; 4 animam coelo reddidit: Stat. Theb. 8.324 (efflare animas et reddere caelo); ossa solo: Prop. El. 1. 22. 8, Sil. Ital., Pun. 6. 160; Pontano De tumulis, 1. 5.7 e 1. 17. 3; 5-6 facunda Solonis ... vox: Iuven. Sat. 10. 274; 6 foelicem obitum: Verino Epigr. var. 7 (In obitu Phylippae Corsinae), 31; 7 Rapta ... florentibus annis: Auson. Parent. 7.5 (Raptus ... florentibus annis); Verino Epigr. var. 6 (Epit. Ursini Lanfredini), 3-4 (florentibus annis / raptum). 
battaglie della Spagna, pacificata contro i Francesi; altri ancora condannano l'inerzia delle potenze cristiane contro l'avanzata dei Turchi. Le esperienze personali evocate riguardano in primo luogo l'insegnamento: esortazioni agli studenti, difesa delle discipline linguistiche; i versi satirici colpiscono sempre il mondo degli studi, con frecciate contro i grammatici litigiosi, gli astrusi legisti, gli astrologi.

Quando subentrano meditazioni più intime, emergono aspettative andate deluse, e il tono talvolta si fa malinconico; proprio tra questi carmi s'incontra il più interessante nella nostra prospettiva, la $A d$ se paraènesis: dove di nuovo viene ripresa una caratteristica metafora petrarchesca, raffigurante l'io del poeta come barca in balìa delle onde, per essere però completamente ribaltata, a riaffermare l'efficacia della ragione e della virtù nel contrastare le avversità della vita ${ }^{19}$ :

Rector ut in tumido puppim regit aequore, gnarus
quos vitet scopulos, quae loca tuta petat,
frangit et hanc, huic cedit aquae, moderamine clavi
infirmam tabulam per freta longa vehit;
sic et, Ari, motus animi fluctusque tumentes
nunc preme, nunc laxa, sub ratione tenens,
indomitumque salum vitae virtute gubernans:
sic supera curas, ut maris ille minas ${ }^{20}$.

Anche in questo caso, peraltro, la cultura poetica di Aires Barbosa si conferma ben sostenuta da letture tanto classiche quanto moderne. Il sintagma tumido aequore, ad esempio, se aveva alle spalle il tumida aequora di Virgilio (Aen. 1. 142), figurava identico nell'Urania di Giovanni Pontano (5. 328). Puppim regit si leggeva in Rutilio Namaziano (De red. 1.456). Vitet scopulos (al v. 2) non ha precedenti classici, mentre ricorda da vicino (pur senza il petrarchesco valore metaforico) espressioni come vitare [...] / tempestates scopulosque latentes di Tito Strozzi (Borsias 3. 154-155), o vitare obstantis scopulos di G.A. Augurelli (Serm. lib. 1. 9.3). Di certo, la clausola loca tuta petat, se può denunciare memoria di Corippo (Iohannis 2. 223: loca tuta petens), o più da lontano di Ovidio (Trist. 4. 1. 19: loca iussa petentem), ha alle sue spalle una reiterata formula strozziana: loca sola peto (Erot. 2. 5. 10), loca sancta petat (ivi 3.1.42), loca sola petunt (ivi 4. 23. 20), a sua volta trasposizione latina di $R v f 35,1-2$ ("Solo et pensoso i più

${ }^{19} \mathrm{Cf}$. ad es. Rvf 189: "Passa la nave mia colma d'oblio / per aspro mare, a mezza notte il verno [...]; / la vela rompe un vento umido eterno / di sospir', di speranze e di disio [...]; / morta fra l'onde è la ragione e l'arte, / tal ch'incomincio a desperar del porto".

${ }^{20}$ Tavares "Tradução do poema Antimoria... " op. cit.: 76-77 (Arii Barbosae Lusitani Antimoria... op. cit.: $\mathrm{xxxx} r$ ). 
deserti campi / vo mesurando"). Staziana è la clausola del v. 3, in realtà in gran parte ispirato da Theb. 10. 183 (Fregit iter, subit ad vidui moderamina clavi); mentre marcatamente ovidiana è l'espressione per freta longa (v. 4), cinque volte utilizzata dal poeta di Sulmona (Her. 7. 46; Met. 7.67 e 8.142; Fasti 3.868 e 5. 660): numerose di conseguenza le riprese umanistiche. Con ordinamento inverso dei due termini, motus animi (v. 5) è locuzione già lucreziana (Rer. nat. 4. 1072) e oraziana (Ars poet. 111); ma nella già incontrata Urania del Pontano, essa figura proprio nella successione adottata da Barbosa (3.558), oltre che in quella anticamente attestata (2.828), peraltro adottata anche da Battista Spagnoli (Sylvae 1. 10. 19). La clausola fluctusque tumentes è probabilmente memore di Virgilio (Aen. 7. 818: fuctu suspensa tumenti), e più da vicino di Sedulio (Carm. pasch. 3. 223: fluctuque tumenti); ma un precedente identico ha in Boccaccio (Egl. 11. 186), e uno molto simile in Tito Strozzi (Erot. 1. 6, 65: fuctus placare tumentes). Nunc preme era formula già di Valerio Flacco (Argon. 1. 334), che ne adattava altre precedenti, leggermente diverse, di Tibullo, Seneca, Lucano, Stazio; e proprio da Stazio (Theb. 3. 392-393: animosaque pectora laxet / sera quies: nobis dolor haud rationis egebit) sembra essere stato suggerito quanto resta del v. 6. Peraltro la clausola del verso, pur senza perfetta coincidenza (ratione tenere/ teneri/tenentur), è tipicamente lucreziana, con ben quattro occorrenze (Rer. nat. 1. 948, 1. 1081, 3. 572, 4.23) già rielaborate, nella forma ratione tenenda, da Basinio da Parma (Carm. var. 20. 38) e Giovanni Pontano (Meteororum liber, 853). La clausola del v. 7, virtute gubernans, nella letteratura antica ha il solo precedente di Optaziano Porfirio (Carmina 15.2), sicché possono forse essere più significativi i precedenti moderni di Matteo Zuppardo, Alfonseis, X 84 (virtute gubernat) e del fiorentino Naldo Naldi, Eleg. ad Laur. Medicen, 3.1 .39 (virtute gubernes). Infine, il paragone conclusivo aveva un precedente in Virgilio, con Mezenzio a sostituire il marinaio (Aen. 10.693696: Ille velut rupes [...] / vim cunctam atque minas perfert caelique marisque); ma non trascureremo che, riferito all'amata, lo aveva anche in Tito Strozzi (Erot. 5. 2. 21-22: Ipsa immota tamen perstat, velut aspera cautes / quae maris assiduas negligit alta minas).

Se le componenti classiche e umanistiche della scrittura poetica barbosiana potevano rappresentare un dato prevedibile (ma ugualmente da sottoporre a verifica), non meno intuibile e coerente, rispetto al ruolo eminente che l'Umanesimo italiano assegnò al genere poetico, è da considerarsi il rilievo attribuitogli da Aires Barbosa (come visto in apertura) quale strumento di conoscenza e formazione. Più in particolare, pur comprendendo testi composti attraverso vari decenni, la produzione letteraria barbosiana mostra rilevanti caratteri di continuità con le tendenze letterarie prevalenti a Firenze negli anni in cui il nostro umanista vi frequentò la scuola del Poliziano (14901495). Prima però di approfondire tali aspetti, appare opportuno rilevare come 
essa nascesse da precise scelte di campo tra le diverse posizioni estetiche che avevano alimentato il dibattito umanistico sulla poesia: concezioni che proprio nella riflessione dell'Ambrogini avrebbero trovato la loro massima sintesi, e che necessariamente richiedono ora un veloce riepilogo.

Non mi soffermerò sulle celebri, inaugurali discussioni affrontate sul tema da Petrarca, che nelle Invective contra medicum aveva proclamato primos nempe theologos apud gentes fuisse poetas; da Boccaccio, che tale principio aveva riaffermato nelle Genealogie deorum gentilium; e da Coluccio Salutati, che nel De laboribus Herculis aveva riconosciuto alla poesia il ruolo di arte civilizzatrice, in quanto discorso figurato atto a rappresentare sotto veste allegorica verità ineffabili, soprannaturali (poetica theologia). Basterà qui rimarcare come tale approccio necessariamente promuovesse una poesia dai contenuti elevati (morali o politici), da affidare a generi altrettanto elevati (epica, tragedia), o almeno disponibili a sovrasensi allegorici (bucolica) o alla comunicazione colta (epistole metriche). Ebbene, tra le più lucide testimonianze di questo orientamento estetico, particolarmente illuminante considero quella proveniente da un centro culturale cui la stessa Firenze guardò sempre con molta attenzione (ne fu originario Savonarola, tra gli altri), e anch'esso fortemente attrattivo nei confronti di dotti portoghesi. Mi riferisco naturalmente a Ferrara, dove come giurista presso lo Studio operò Ludovico Teixeira, e dove tra il 1497 e il '99 soggiornò Henrique Caiado, già allievo del Poliziano a Firenze, di Filippo Beroaldo a Bologna, ma ora in contatto con numerosi letterati ferraresi, a cui indirizzò molti epigrammi: e tra i destinatari non mancò quel Tito Vespasiano Strozzi che, oltre a comporre opere poetiche che già sappiamo capaci di lasciar tracce importanti nella scrittura poetica di Aires Barbosa, assieme al figlio Ercole dedicò vari epigrammi allo stesso Teixeira ${ }^{21}$. Molto importanti anche per i poeti portoghesi formatisi a Firenze e Ferrara (come Caiado e il nostro Barbosa, poco o nulla propensi al canto amoroso, e dediti invece a quello di soggetto morale, politico, religioso), risultarono dunque certamente le dispute manifestatesi alla celebre scuola ferrarese di Guarino da Verona.

Le teorie letterarie del maestro sono ben testimoniate, oltre che dal suo epistolario e dagli scritti didattici, da un documento fondamentale quale è la Politia litteraria di Angelo Decembrio, uno dei tanti umanisti formatisi alla sua scuola. Raffinato dialogo, in cui tutti i componenti del circolo guidato da

${ }^{21}$ Per i rapporti tra gli Strozzi e il Teixeira rimando a Vincenzo Fera, Una ignota expositio... op. cit.: 20. Quanto alle frequentazioni ferraresi di Henrique Cayado, nell'ed. Henrique Caiado, Aeglogae et sylvae et epigrammata Hermici. Bononiae. Benedictus Hectoreus [Faelli], 1501, si incontrano epigrammi dedicati a Tito Strozzi (Kır $r$, Kvır $r$ ), Ercole Strozzi (Hvr-v, Kıv), Celio Calcagnini (Kviv), Luca Ripa (cc. Giıv, Hır, Hııv, Hıvr, Hvv, Mııv), Alberto Tassino (c. Giıv), Gabriele Tassino (Hıır, Hvr), e altri. Tra i non ferraresi, non manca il Poliziano (c. Gviv, Hiıv). 
Guarino e da Leonello d'Este dialogano sulle più varie questioni culturali, l'opera (intrapresa negli anni' 40 e conclusa intorno al 1463) affida le valutazioni di merito soprattutto al marchese-umanista, che sintetizza il pensiero estetico guariniano nella seguente regola aurea:

Decet enim in primis ea librorum volumina perquirere, quae hominem efficiant eloquentem et industrium, a naturali usu minime discedentem ${ }^{22}$.

Tale principio non comportava una svalutazione della poesia. Il rischio di desumerne criteri di giudizio angustamente utilitaristici era certo presente, e infatti nell'opera non manca chi ne deduce la superiorità di Tito Livio rispetto a Virgilio. Leonello risponde tuttavia non solo rivendicando la grande ricchezza informativa delle opere virgiliane, ma anche illustrando i superiori valori che pongono la poesia su un piano privilegiato rispetto alle altre scritture letterarie, sia quanto ad altezza d'ispirazione che per efficacia didattica:

Nec enim a poetis primum incepisse pigebit. Quorum eo altiora vigent ingenia, quo magis animum delectare videntur musico quodam artificio, et, si dicifas est, harmoniae caelesti consimilia. Dicimus autem egregios non omnis generis poetas. Unde merito eruditissima carmina scribentibus poetae nomen inditum est, quod 'factorem' vel 'auctorem' et fere 'primarium' indicat, et ipsum poema 'facturam' vel 'opus'. Ac ipsum

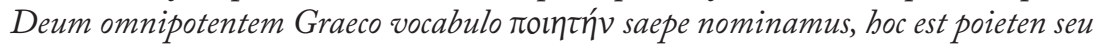
poetam, quamvis pro more sonoque Latine 'factorem' magis interpretamur. Huicque divino pioque hominum generi, non irreligioso, ut stultum vulgus existimat, laurea dicata aliaque ab imperatoribus munia donari solita. Ad hoc in lectione carminis iis, qui metricam et solutam tractant orationem, voluptas accedit maior, faciliusque carmen memoria retinetur et imbibitur, quo sensim animus praecipue iuvenilis cum delectatione simul in sermonum gravitate nutritur ${ }^{23}$.

Il circolo guariniano, dunque, attribuiva ai poeti non solo il dono di esprimersi in forme didatticamente utili perché più facilmente memorizzabili, ma soprattutto un ingegno in possesso di una creatività a suo modo divina, in virtù della musicalità, simile all'armonia dei cieli, che ne pervade le opere: immagini che ritroveremo nello stesso Poliziano. Tuttavia, proprio l'eccezionale natura e l'alta funzione educativa attribuite alla poesia non rendevano possibile, nella Politia litteraria, un apprezzamento che prescindesse da contenuti formativi;

${ }^{22}$ Angelo Camillo Decembrio, De politia litteraria, ed. N. Witten. München-Leipzig, K.G. Saur, 2002: 152 (1. 3. 12). L'intera pars tertia (: 148-159) è dedicata al tema che qui ci interessa: Qui modus ordoque servandus in curanda poliendaque bibliotheca, deinde quo pacto struenda, scilicet qui libri in ea ex Latinis et Graecis opportuni, ac primo de metricis auctoribus, inter quos de Virgilio praecipua mentio, ac Tullio officiorum atque Salustio per Leonellum.

${ }^{23}$ Ibid.: 153 (1. 3. 14). 
in particolare, quell'aderenza alle esperienze concrete della vita (di una vita orientata da forti valori umani e civili), che rendeva imprescindibile la lettura di Virgilio, Terenzio e Giovenale, non trovava riscontro nella frivola poesia lirica ed elegiaca. I maggiori esponenti di questa sono perciò frettolosamente ricordati solo perché si ritiene doveroso prestare attenzione a quegli autori che gli antichi ritennero degni di lode ${ }^{24}$.

Una prima alternativa a questo sistema estetico, per diversi aspetti ben attivo (come visto) nella stessa poetica barbosiana, si presentò nel 1429, grazie all'azione congiunta di un giovane poeta siciliano, Giovanni Marrasio, che emigrato a Siena vi compose una raccolta elegiaca dedicata ad Angela Piccolomini (l'Angelinetum), e dell'umanista che in quegli anni stava traducendo in latino molti dialoghi di Platone (in particolare il Fedro), ossia Leonardo Bruni: ai quali si dovette una nuova teorizzazione della natura divina dell'ispirazione poetica (appunto su base platonica), con esplicita rivendicazione della superiorità di una poesia generata da sacro furore (anche se limitata ad apparentemente futili temi amorosi) rispetto ad un'altra magari dai contenuti più alti, ma dettati dalla ragione ${ }^{25}$. Riprendendo infatti un accenno compreso nell'elegia introduttiva dell'Angelinetum, a lui indirizzata (Indulgere velis nostro, Arretine, furori, / sive sit ille furor, sive sit ille dolor, vv. 2122), il Bruni ne approfondì le implicazioni filosofiche, esplicitando il principio estetico sopra indicato:

non enim omne opus poema est, ne si versibus quidem constet, sed illud praestans, illud hac honorata nuncupatione dignum quod afflatu quodam divino emittitur. Itaque quanto vaticinium coniectationi dignitati praestat, tanto poema, quod ex furore fit, sanorum hominum artificio est anteponendum.

Non solo. Sempre su basi platoniche (ma non senza apporti già stilnovistici), il Bruni aggiungeva come tale furor fosse precisamente da identificarsi con l'ispirazione d'amore:

Haec igitur vehemens occupatio animi atque correptio amor vocatur [...]. Sed unum scias volo, me non tam tibi eximiam hanc palmam esse tribuendam existimare quam

${ }^{24}$ Cf. ibid.: 157-159 (1.3.25-28).

${ }^{25}$ Segnala Donatella Coppini (“L'ispirazione per contagio: 'furor' e 'remota lectio' nella poesia latina del Poliziano”, in Vincenzo Fera - Mario Martelli (edd.), Agnolo Poliziano, poeta scrittore filologo. Firenze, Le Lettere, 1998: 127-164) come sia significativo "che il concetto di furor, in Platone comunque funzionale alla svalutazione della poesia, almeno su un piano gnoseologicoepistemico, sia assunto nell'Umanesimo a fondamento della proclamazione dell'eccellenza della stessa poesia [...]: troppo funzionale si presentava la categoria di furor, troppo appropriata l'immagine di una poesia di natura e origine divina, perché tali nozioni non venissero davvero entusiasticamente assunte" (: 131). Sul tema, cf. anche Raoul Bruni, Il divino entusiasmo dei poeti. Torino, Aragno, 2010. 
Amori. Ille est enim qui verba tibi dictat, qui sententias ostendit, qui varietatem et copiam et elegantiam subministrat ${ }^{26}$.

In realtà, questa promozione di Amore al ruolo di divinità ispiratrice della poesia più compiuta, teorizzata dal Bruni con almeno un ventennio d'anticipo rispetto al contributo decisivo di Marsilio Ficino, sarebbe stata accolta con alterno favore. Di certo, tuttavia, essa rappresentò un presupposto fondamentale del fiorire dell'elegia neolatina sin dagli anni '40, ad opera di giovani autori che non aspettavano altro per sganciarsi dalle convinzioni estetiche dei loro maestri, orientate a sottomettere rigidamente la poesia a finalità etiche e politiche. Si trattò, beninteso, di un affrancamento provvisorio, perché quegli stessi giovani (come Tito Vespasiano Strozzi o Basinio da Parma) non si sarebbero sottratti, più avanti, a cimentarsi con l'epica, il genere poetico più rispondente all'esigenza, mai tramontata, di una poesia civilmente impegnata. Sta di fatto che, per tornare al nostro esemplare contesto ferrarese, nel quale non a caso proprio il Marrasio si trasferì nel 1432, i più talentuosi allievi di Guarino decisero di esordire poeticamente all'insegna dell'elegia, talvolta con espliciti omaggi al poeta moderno che l'aveva sdoganata: è il caso ad esempio di Basinio da Parma, che negli anni del suo studentato ferrarese (1446-49) compose una raccoltina elegiaca (Cyris), introducendola con una inequivocabile citazione del tema del furor ${ }^{27}$.

Partendo da tali premesse, ben maggiore rilievo avrebbe tuttavia assegnato Basinio al ruolo del poeta (seppur sempre su base platonica) nel capolavoro composto dopo il trasferimento alla corte riminese di Sigismondo Pandolfo Malatesta (1449): il Liber Isottaeus, uno splendido romanzo epistolare elegiaco, molto fortunato ai suoi tempi, in cui quattro personaggi (Sigismondo, Isotta, il Padre della fanciulla e il Poeta) si indirizzano trenta epistole metriche equamente suddivise in tre libri, in apparenza celebrative dell'amore tra i due protagonisti, in realtà orientate a una profonda riflessione sul destino umano (tra amore, morte e prospettive ultraterrene), sviluppata in una complessa dialettica tra l'ottimismo filosofico del Poeta e le dolenti perplessità

${ }^{26}$ Traggo questo e i precedenti brani da Giovanni Marrasio, Angelinetum et carmina varia, ed. G. Resta. Palermo, Centro di studi filologici e linguistici italiani, 1976: 144-48. Sempre dal Bruni, nella prefazione al proprio commento a Virgilio del 1462, Cristoforo Landino avrebbe mutuato le precise parole per indicare l'assimilazione di vaticinio e poesia (cf. Coppini, "Lispirazione per contagio..." op. cit.: 138-139).

${ }^{27}$ Nec minor in nobis furor est, si credis amanti, / quam fuit in vestro pectore caecus Amor [...]. I Et pereo, fateor, neque enim celare furorem / posse reor: medio stat mea flamma foro (Cyris, I, 27-28, 35-36; cf. Le poesie liriche di Basinio: Isottaeus, Cyris, Carmina varia, a cura di F. Ferri. Torino, Chiantore, 1925: 78). Per un profilo biografico del poeta, cf. Augusto Campana, "Basinio da Parma", in Dizionario biografico degli italiani. Roma, Istituto della Enciclopedia Italiana, vol. 7, 1965: 89-98. 
di Sigismondo e Isotta ${ }^{28}$. Lo scenario dell'opera, in effetti, è estremamente malinconico. Sigismondo soffre i continui distacchi dall'amata (I 1) dovuti ai suoi impegni di capitano di ventura, e, dopo numerosi travagli, ne subisce impotente la morte (III 7); non trovando alcuna consolazione nel mirabile sepolcro che (come nella vita reale) le aveva predisposto, si propone di ricorrere ad arti magiche, pur d'incontrare lo spettro della fanciulla (III 9). Ancora più infelice Isotta: spesso sola (I 2), non ha una fede che la conforti, e cerca una speranza d'eterno nelle parole del Poeta (II 1); avverte che perderà il bambino che ha in grembo, vittima innocente delle proprie colpe (II 5), e in effetti così accadrà (nel racconto come nella vita), pochi giorni dopo il parto (II 6); e ben poco confortata dal sepolcro allestitole (III 6), muore disperata, imprecando contro gli dèi crudeli (III 8: nella finzione poetica, visto che storicamente, invece, ella sopravvisse diversi anni al proprio amante e poi sposo).

Dinanzi a tanto dolore, solo il Poeta cerca di dare, con ogni argomento, prospettive e significati positivi: suo compito nel corpo del racconto è appunto quello di distribuire sapienza, anche se con parziale successo ${ }^{29}$. Così, ad Isotta che gli chiede se la vita si protragga dopo la morte, e con essa l'amore per le persone care, il Poeta risponde affermativamente (2.2), basandosi su una concezione dell'anima come principio di movimento che risaliva al $\mathrm{Fedro}^{30}$, ma negando, sulla base della non inferiore testimonianza di un poeta, Virgilio, quella teoria della metempsicosi (attribuita a Pitagora) che avrebbe comportato come ineludibile corollario l'oblio delle esperienze terrene ${ }^{31}$. E ugualmente a Platone, Omero e Virgilio (tutte voci divinamente ispirate) si affida il Poeta nel rassicurare Sigismondo quando il principe, disperato per la morte di Isotta,

${ }^{28}$ Ho trattato più distesamente questi temi nello studio Italo Pantani, Responsa poetae. Corrispondenze poetiche esemplari dal Vannozzo a Della Casa. Roma: Aracne, 2012: 133-171 ("L'approdo al romanzo epistolare").

${ }^{29}$ Del resto, si ricorderà che Sigismondo fu scomunicato per eresia da papa Pio II (il grande umanista E.S. Piccolomini), con l'accusa di negare l'immortalità dell'anima e la resurrezione dei morti, nonché aver praticato una sorta di culto pagano della sua concubina, la divina Isotta (il tutto inquadrato, come possibile alternativa allo scetticismo, in un esibito ritorno a un platonismo precristiano).

${ }^{30}$ Quodque agitur per se, se nunquam deserit; ut quod / principium nunquam noverit ante suum. I Se movet bic per se nulloque agitante movetur; / coepit et ut nunquam sicque perennis erit. / Corporis ut moles animis est omnis adempta, / iuditio vivunt hi sine fine meo (Le poesie liriche di Basinio... op. cit: 20, vv. 35-40). Cf. Platone, Fedro, 245 c-e, 246 a-d. A Basinio peraltro tale pensiero giungeva attraverso la mediazione di Cicerone (Tusc. 1. 23, 53; De re pub. 6. 27) e Macrobio (Comm. in Somn. Scip. 2. 13, 1; 2. 15, 1-18), pressoché trasposti in versi dal parmense.

${ }^{31}$ Mensne eadem maneat tristi compage solutis, / ut reor, est paucis explicuisse datum. / Respondere canit curasque aequare Sichaeum / coniugis Aonio carmine Virgilius. / Ergo aliquid post fata sumus, vitaeque prioris, / quisquis habet, memores vivimus usque, locus. / Nam potare animas Lethaei oblivia fontis, / in formas demum quis putet ire novas? / Non mibi Pythagoras hoc unquam suaserit auctor, / sit licet in raris nomen in orbe suum. / Divinos animos caelesti ab sede profeto / communes brutis noluit esse Deus (Le poesie liriche di Basinio...... op. cit.: 20-21, vv. 41-52). 
si chiede se potrà mai ritrovarla $(3.10)^{32}$. Di fatto, il Poeta dell'Isottaeus svolge, nel corpo del racconto, il compito di consulente filosofico e spirituale che Basinio ricoprì storicamente nella corte di Sigismondo: il quale non mancò di suggellare la funzione sapienziale riconosciuta al suo poeta tumulandone le spoglie (a seguito della precoce morte intervenuta nel 1457) in una delle arche monumentali che ornano il fianco destro del suo Tempio Malatestiano, accanto a quelle che raccolgono i resti del famoso filosofo neoplatonico Gemisto Pletone, e di Giusto dei Conti, altro importante poeta (volgare), giunto per primo a Rimini a diffondere l'interesse per questa scuola di pensiero.

Se Basinio da Parma mise direttamente in scena il poeta nelle sue più alte attribuzioni (svolte col supporto sapienzale di antichi poeti e di filosofi), in quegli stessi anni a Ferrara due altri brillanti allievi di Guarino si trovarono invece a discuterne con opposti argomenti ${ }^{33}$. A lungo riluttante rispetto ai precetti del maestro, Tito Vespasiano Strozzi si dedicò liberamente lungo tutti gli anni '40 e '50 a una lirica capace di ridare freschezza alle topiche situazioni della poesia elegiaca, attraverso la contaminazione con stilemi del Canzoniere petrarchesco: nulla di sorprendente, dunque, se tale elegante disimpegno suscitò ben presto critiche nell'ambito della scuola guariniana. Famosa, in particolare, fu la reazione di un adolescente ungherese, Giano Pannonio (János Csemiczei), giunto tredicenne a Ferrara nel 1447, e destinato a diventare il più grande poeta dell'umanesimo magiaro, in quanto acuto cultore del genere epigrammatico e, soprattutto, intenso autore di elegie dedicate a profondi temi esistenziali. Di fronte a una lirica in cui lo Strozzi aveva rappresentato la propria gioia per un anello donatogli dall'amata ${ }^{34}$, in un testo non posteriore al 1450 Giano espresse il proprio fastidio con argomenti perfettamente conformi con la poetica guariniana:

\section{Cantatas alio transferre vetabere flammas, sic semper turpis te retinebit amor [...]. Excute damnosas captivo e pectore curas,}

${ }^{32}$ Ipse tamen referam sacri divina Platonis / plurima, quae Graiis me docuere sonis. / Ille putat rursus mortale in corpus ituras / esse animas pleno temporis orbe sui. / Nec minus Elysios post fata revisere campos / rursus et aeterna conditione trabi [...]. I Ipse Menoetiades, magno si crederis Homero, / venit Achilleos mortuus ante pedes / candidaque ossa sui Phtiae portaret ad urbem / fidus ut Aeacides iussit et inde fugit. I Sic te si affari cupiat tua cara puella, / forte potest vultus ante venire tuos. I Aeneaeque fuit simulacrum triste Creusae / ante oculos, trepidas dum fugit illa manus. / Quare ne dubites illam tibi posse reverti / et curas dulci voce levare tuas (Le poesie liriche di Basinio... op. cit.: 72-73, vv. 31-36, 43-52).

${ }^{33}$ Anche questo argomento ho trattato più distesamente in altre sedi: dapprima in Italo Pantani, «La fonte d'ogni eloquenza» op. Cit.: 278-282, più distesamente in Italo Pantani, Responsa poetae op. cit.: 113-127.

${ }^{34}$ Eroticon libri 1. 7 (Ad annulum quo donatus fuerat ab amica): cf. Della Guardia, Tito Vespasiano Strozzi... op. cit.: 18. 
deme Cupidineis et tua colla iugis;

prorsus et ingenuas convertere totus ad artes,

et grave neglecto carmen amore cane [...].

Scribere quae valeas sunt plurima praeter amorem,

sive nova arrident, sive vetusta placent;

bellica sive iuvat clarorum gesta virorum

carmine materiae conveniente suae,

sive referre togam ${ }^{35}$.

Questa elegia diede origine a una tenzone, destinata a grande fortuna (come provano memorie dello stesso Poliziano, su cui tornerò), che si protrasse per ben sei componimenti, durante i quali Tito Strozzi non difese la propria poesia (sulla scia del Marrasio) attribuendone la materia sentimentale all'azione di un sacro furore, quanto, al contrario, assumendo gli umili panni, petrarcheschi anche nelle immagini, dell'uomo consapevole del proprio errore, ma impossibilitato a liberarsene perché schiavo delle sue passioni:

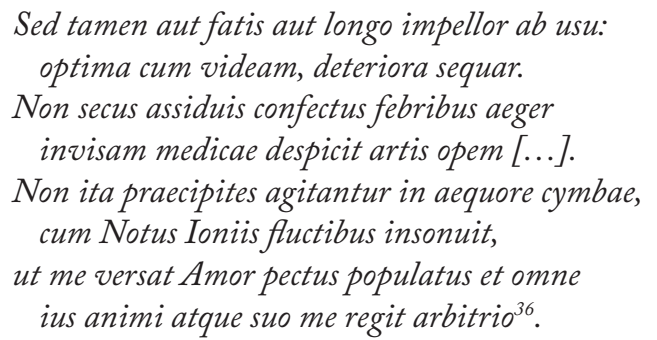

Naturalmente, in questa e in altre occasioni, lo Strozzi non mancò anche di celebrare la potenza di Amore e le sue azioni benefiche (compresa quella esercitata sui poeti); ma, in mancanza di una convinta adesione alla poetica platonica del furor, lo fece sostanzialmente in termini lucreziani e virgiliani. E infatti evidente, al contrario, come solo una piena attribuzione al poeta, su base platonica, di facoltà e compiti sapienziali e divinatori, poteva accreditare la sua arte a prescindere dai contenuti proposti, legittimando, in particolare, quelli amorosi.

${ }^{35}$ Elegia II 8, 79-80, 135-138, 163-168 (cf. Giano Pannonio, Poemata quae uspiam reperiri potuerunt omnia, 1784, ed. S. Teleki, 2 voll. Traiecti ad Rhenum (Utrecht), apud Barthol. Wild (rist. anast.: Budapest, Balassi Kiadó, 2002: 378-390).

36 Eroticon 1. 8. 55-58, 65-68 (cf. Della Guardia, Tito Vespasiano Strozzi... op. cit.: 18-33). Riscontri lessicali: per il v. 56 (Optima cum videam, deteriora sequar) cf. Ovidio, Met. 7. 20-21, s. Paolo, Rom. 7. 19, e Rvf 264. 136; per i vv. 57-58 (aeger / invisam medicae despicit artis opem) cf. Properzio 2. 4. 13, ma anche Rvf 75. 1-3; per i vv. 65-66 (agitantur in aequore cymbae) cf. Properzio 2. 4. 19-20 (in senso antifrastico), e Ovidio, Trist. 1. 1. 85, ma soprattutto Rvf 132 (10-12), 189, 235 e 272; per il v. 67 (me versat Amor, pectus populatus) cf. Ovidio, Am. 1. 2. 8. 
Il ruolo svolto dal pensiero di Marsilio Ficino in questa opera di conciliazione tra sapientia e furor, fin dall'epistola De divino furore a Peregrino Agli del 1457, è talmente noto da sconsigliare qui qualsiasi approfondimento ${ }^{37}$. Gioverà però ricordare che nel 1491, anno che si sarebbe rivelato ricchissimo di stimoli per Aires Barbosa (da pochi mesi giunto a Firenze), Ficino elaborò una seconda epistola De divino furore (quasi una postilla a quella del 1457), ora indirizzata a Pietro Dovizi, nella quale "i quattro furori platonici appaiono ancora uniti nel segno della poesia" ${ }^{38}$. Del resto, a prescindere da possibili influssi diretti sul nostro Barbosa, questi approdi dell'estetica ficiniana devono comunque interessarci in quanto fondamentali per le teorie poetiche di Angelo Poliziano, oggetto a sua volta di autentica venerazione da parte di Aires Barbosa, come provano i frequenti e commossi ricordi dell'Ambrogini nei suoi testi, pervasi dall'orgoglio di avere studiato presso un tale docente ${ }^{39}$.

Ricorderemo allora che, sempre in quel nodale 1491, Poliziano ripubblicò con nuova dedica i Nutricia, ossia la più pertinente a questo nostro percorso tra le Silvae: le prolusioni in versi con cui l'Ambrogini aveva aperto i suoi corsi degli anni '80, tutti incentrati su grandi poeti, da Omero a Virgilio a Stazio (laddove, proprio quando Barbosa giunse a seguirne le lezioni, egli si volse all'esegesi di Aristotele etico, fisico e soprattutto logico). Proprio dei Nutricia non si può qui omettere di ricordare, in particolare, alcuni imprescindibili versi:
Donec ab aetherio genitor pertesus Olympo socordes animos, longo marcentia somno
pectora, te nostrae, divina Poetica, menti
aurigam dominamque dedit [...].
Nam simul ac pulchro moderatrix unica rerum
suffulta eloquio dulcem sapientia cantum

${ }^{37} \mathrm{Cf}$. Marsilio Ficino, Lettere. I. Epistolarum familiarium liber I, a cura di S. Gentile. Firenze, Olschki, 1990: 19-28, epistola 1. 6. "Ficino riprende subito, a esordio di lettera, la dicotomia ars / furor proposta dal Bruni, attribuendo alla poesia del destinatario le positive caratteristiche di unopera divinamente ispirata. Ma la contrapposizione non è drastica ed è prospettata la possibilità di convivenza dei due elementi" (Coppini, "L'ispirazione per contagio...” op. cit.: 137).

${ }^{38}$ Ibid.: 141. Anche se "della poesia, e della persona, di Lorenzo; lomaggio al quale [...] condiziona il tono 'leggero' della trattazione” (ibid.).

${ }^{39}$ Celebrato in versi con appellativi quali meus Angelus, Gymnasii celebris celeber magister, poeta, orator; uomo capace di esprimersi Latino / cum sale, Cecropio cumque lepore simul; insomma, Ille, quasi e caelo sumptus, fuit angelus ignis (dall'epigramma In Nebulonem grammatistam iactuose uanum, ed. da José Henrique Rodrigues Manso, Comentário de Aires Barbosa ao segundo livro da Historia Apostolica de Arátor. Lisboa, Fundação Calouste Gulbenkian, 2011: 732-735, vv. 17-22, 27). Del resto, nel proprio commento ad Aratore (c. IIIr), Barbosa rivela non solo la conoscenza della Lamia (prolusione al corso sugli Analytica priora di Aristotele, recitata nel novembre del 1492), ma giunge a servirsi in funzione esegetica (c. cxxviv) del capolavoro filologico del Poliziano, i Miscellanea (cf. Manso, Comentário... op. cit.: 34, 408, 768). 
protulit, et refugas tantum sonus attigit aures,

[...] didicere quid usus

discrepet a recto; qui fons aut limes honesti;

qui ve fide cultus quid ius aequabile, quid mos, quid poscat decor et ratio [...].

Nunc age, qui tanto sacer bic furor incitet oestro

corda virum [...], expediam [...].

Nec tamen in nullis hominum simulachra refulgent

mentibus, arcanam caeli testantia Musam

permixtumque Iovem [...].

Is rapit evantem fervor [...],

inque suos humana ciet praecordia cantus.

[...] Mirantur et ipsi

saepe (quis hoc credat?) quae nuper cumque, recepto

numine, legitimi cecinere oracula vates ${ }^{40}$.

Poliziano teorizza dunque una poesia come dono di Dio agli umani, cui l'intelletto non bastava per uscire dalla barbarie. La sapientia divina (poi così cara a Barbosa), esprimendosi attraverso il canto dei poeti, diede avvio alla civiltà: e questo, naturalmente, fa della poesia la più alta delle scienze e delle arti, seconda solo alla teologia. Il sacro furore che ispira i poeti si deve alla particolare sensibilità di questi ultimi verso la divina armonia che regola il movimento dei cieli: quando tale furor li pervade, i poeti diventano come oracoli e vati, annunciatori di un messaggio di cui non sono proprietari. Si tratta di un quadro di pretta derivazione platonica e ficiniana (ancorché convergente con la poetica del subitus calor affermata da Stazio nelle sue Silvae), in cui la collocazione della poesia al vertice del sapere umano, in quanto rivelatrice di verità e di valori, giungeva da un lato a confermarne il ruolo fondativo nel quadro della cultura umanistica (senza possibilità di equivoco con l'interessata autopromozione di tanti verseggiatori), dall'altro a chiudere e sanare il lungo confronto che aveva contrapposto, nelle teorizzazioni d'età umanistica, la poesia ispirata da un incontrollabile furor, ma per questo estemporanea, inadeguata ai generi più nobili, rispetto a quella impegnata su contenuti alti, ma estranei all'esperienza e alla sensibilità dell'autore ${ }^{41}$.

\footnotetext{
${ }^{40}$ Poliziano, Silvae... op. cit.: 170-71, 176-80 (vv. 67-70, 75-77, 81-84, 139-140, 144, 156$158,163,169,182-184)$.

${ }^{41}$ Sulla "difficoltà latente", contenuta nel citato brano dei Nutricia, tra la concezione della poesia come "forma di raptus" e la natura dell'incivilimento umano, "che è una forma di persuasione prolungata nel tempo e resa istituzionale", si sofferma Paolo Paolini , "Sul tema dell'incivilimento attraverso la poesia nei 'Nutricia' del Poliziano e in altri autori”, in Italianistica, XII (1983): 217-234 (: 219); il quale, anche sulla base di altri testi polizianei, riconosce la soluzione dell'Ambrogini "in una mediazione che, pur salvando il primato ideale e cronologico della poesia, le attribuisse insieme una sorta di sapienza filosofica implicita e come aurorale,
} 
A tale risultato, peraltro, Poliziano poté giungere in virtù non solo delle premesse ficiniane, ma anche dell'attenzione da lui riservate alle elaborazioni del contesto ferrarese, e in particolare alle posizioni di Giano Pannonio, di cui molto apprezzò gli alti compiti conoscitivi attribuiti alla poesia. Lo testimoniano innanzitutto le ampie tracce lasciate, nell'elegia indirizzata dall'Ambrogini a Bartolomeo Della Fonte (1473), proprio dal carme di Giano a Tito Strozzi sopra ricordato (in particolare dai versi 183-206, dove l'autore enumera i prìncipi e gli Stati che Tito potrebbe celebrare), carme di cui peraltro perfino nelle Stanze (1. 51. 4: «teda legittima») si riecheggia la definizione elogiativa dell'amore coniugale (v. 81: «legitimas taedas»). Comprovano poi tale attenzione le memorie, riscontrabili nell'elegia in morte di Albiera degli Albizi (1473), di almeno cinque carmi del Pannonio (1.3. 9; 1. 6. 147$152 ; 1.9 .110 ; 1.10 .3 ; 1.12 .24)$; o ancor meglio l'intera praefatio alla selva Manto (1482), "esemplata fedelmente, nel suo impianto, nel suo svolgimento e nella sua trama allegorica, sull'analoga prefazione in distici che il Pannonio aveva premesso alla sua silva esametrica in onore di Guarino Veronese". Una definitiva conferma è infine rappresentata proprio dai Nutricia (1486), i cui primi sedici versi sono "chiaramente ricalcati su un analogo brano dell'elegia del Pannonio in morte della madre", già "ampiamente utilizzata nell'epicedio per Albiera degli Albizi" ${ }^{42}$.

Se l'ininterrotta fiducia barbosiana nell'arte poetica ebbe certo i suoi fondamenti in questi insegnamenti del Poliziano, è tuttavia indubbio che $\mathrm{i}$ criteri estetici adottati e promossi dall'autore dell'Antimoria (rifiuto di ogni retorica ambiguità, rinuncia a ornamenti mitologici, abbandono dei temi amorosi, decisa predilezione per quelli etico-religiosi, moderata apertura a quelli politici) mostrano forti punti in comune con altre componenti della cultura poetica fiorentina di fine ' $400^{43}$. Quest'ultima infatti, se da un lato non dimenticava l'alta funzione sapienziale e civilizzatrice attribuita alla poesia nel corso del secolo, dall'altro tendeva a darne un'interpretazione in chiave fortemente moralizzata, o meglio propriamente religiosa, aderendo in larga

destinata a successivi sviluppi in senso oratorio" (: 231).

${ }^{42}$ Tutti i riscontri e le citazioni relativi alla fruizione polizianea dei testi del Pannonio sono tratti da Francesco Bausi, "Poliziano e la poesia umanistica contemporanea", in V. Fera - M. Martelli (edd.), Agnolo Poliziano, poeta scrittore filologo... op. cit.: 165-193 (in particolare 176183, 190-191).

${ }^{43}$ Criteri estetici che si trovano ribaditi nelle espressioni di elogio riservate al poeta Aratore nella Praefatio al I libro della Historia apostolica: dove Barbosa difende, contro l'estremismo di taluni umanisti, lo stile semplice delle Sacre Scritture, e condanna, ricorrendo a una celebre immagine, prima petrarchesca (Famil. 23. 19) e poi polizianea (Ep. Paulo Cortesio suo) le "scimmie imitatrici" dell'antica eloquenza, specie se disposte ad accogliere espressioni empie. Viceversa, a suo giudizio "nostra id est sacra et ecclesiastica poesis tota casta est, sancta, virilis: in summa, virgo incorrupta" (cf. Barbosa, Aratoris cardinalis Historia apostolica... op. cit: cc. AırvIIIr, e Osorio, O Humanismo português... op. cit.: 54-55). 
misura agli insegnamenti di Girolamo Savonarola ${ }^{44}$. Non a caso, sempre a quel capitale (per la formazione barbosiana) 1491 risale l'Apologeticus de ratione poeticae artis, nel quale il seguitissimo frate definì poesia divinamente ispirata solo quella biblica, l'unica cui Dio avesse conferito sapientia e verità; bugiarda era dunque da ritenersi, in particolare, la poesia dei pagani (da non leggere né tantomeno imitare, soprattutto nell'uso dei miti), mentre quella moderna, pur se inferiore sul piano conoscitivo a teologia e filosofia, poteva essere accettata se evocatrice di virtù:

Verum quidem non amatoria, non laudes idolorum, non turpia, sed virorum fortium gesta atque moralia versibus descripserunt et bene usi sunt arte poetica et modo eius. Hos igitur damnare nec possum nec debeo ${ }^{45}$.

Quanto in profondità questo insegnamento incidesse nelle coscienze e nelle opere di numerosi letterati, è dato ben noto: si può qui ricordare il caso esemplare degli Epigrammata di Ugolino Verino, proprio nel 1491 sottoposti a rimozione dei contenuti mitologici e più distintamente neoplatonici, in componimenti peraltro fin dall'inizio dedicati a temi morali e teologici, nonché a elogi funebri di familiari e amici; ma analogo percorso è dato riscontrare in vari altri letterati di area medicea, come lo stesso Lorenzo, Giovanni Nesi o Girolamo Benivieni ${ }^{46}$. Minore successo, peraltro, ebbe l'opposizione del Savonarola alla poesia d'argomento religioso: condannata senz'altro dal frate come bestemmiatrice qualora "travestisse" mitologicamente la materia sacra, ma disapprovata anche in assenza di idolatre contaminazioni, in quanto le sue ambizioni retoriche ed estetiche avrebbero inevitabilmente distolto l'attenzione (di poeti e lettori) dalla verità dottrinale dei contenuti:

magis laudari de ornatu et carminum cursu ac vocabulorum integritate gestiunt quam de disciplina morum descripta. Nam et maiori eis curae est integritas locutionis quam doctrinae, nec possunt inanis gloriae vitare peccatum, immo nec abscondere ${ }^{47}$.

In realtà, perfino un fervente savonaroliano come il Verino, pur evitando la mitologia e perseguendo la massima sobrietà stilistica, non rinunciò affatto

${ }^{44}$ Riscontri tra la poetica di Barbosa e le tesi di Savonarola rilevò già José Sebastião da Silva Dias, A politica cultural da época de D. Joao III. Coimbra, Universidade de Coimbra, Instituto de Estudos Filosóficos, 1969: 222-225.

${ }^{45}$ Girolamo Savonarola, Apologeticus, in Id., Scritti fllosofici, a cura di G.C. Garfagnini e E. Garin. Roma, A. Belardetti, vol. 1, 1982: 211-272, in particolare 266.

${ }^{46} \mathrm{Su}$ questi temi cf. almeno Francesco Bausi, "Ugolino Verino, Savonarola e la poesia religiosa tra Quattro e Cinquecento", in G.C. Garfagnini (ed.), Studi savonaroliani. Verso il V centenario. Firenze, Sisnel, 1996: 127-135, e Ugolino Verino, Epigrammi, a cura di F. Bausi. Messina, Sicania, 1998: 33-123.

${ }^{47}$ Savonarola, Apologeticus... op. cit: 266. 
a praticare la poesia sacra (producendo ad esempio una versione in esametri dell'intero Vetus et Novum Testamentum), né a rivestirla di un moderato abbellimento classicheggiante; secondo un compromesso almeno in parte riconducibile all'opera conciliatrice di un altro predicatore, l'agostiniano Mariano da Genazzano, il quale divenne proprio in questi anni "il principale punto di riferimento di quanti (dal Poliziano al Brandolini, al Domizi) ritenevano possibile e legittimo sposare le verità cristiane con le attrattive della poesia e - in generale - con la cura della forma e dello stile, ossia, in una parola, con il magistero dei classici" ${ }^{4}$. Se dunque, analogamente, anche il nostro Barbosa, nel costante rifiuto di contenuti amorosi e abbellimenti mitologici, si sarebbe cimentato nella scrittura di un carme come l'Antimoria (ampiamente incentrato su contenuti biblici), di epigrammi a tema esclusivamente didattico, morale e civile, nonché nello studio di un poema, l'Historia apostolica di Aratore, esempio tra i più tipici di trasposizione poetica classicheggiante della sacra Scrittura, tali orientamenti estetici non potevano che nascere dal concorso delle suggestioni sopra riassunte: l'assoluta fiducia riposta dalla cultura umanistica nelle virtù conoscitive, formative e perfino sapienziali della poesia (come le aveva felicemente rappresentate Basinio, ed esemplarmente sintetizzate Poliziano); l'identificazione di tali virtù con quelle più strettamente concernenti l'ambito morale e civile, secondo l'approccio (per fermarci agli autori citati) di un Guarino e un Pannonio; l'impronta moralizzatrice apportata (anche sul piano delle risorse stilistiche, come l'abbandono della mitologia pagana) dalla predicazione savonaroliana, proprio negli anni in cui Barbosa soggiornava a Firenze; le aperture, infine, che anche la letteratura medicea più sensibile a tale insegnamento si riservava sul piano della forma e dell'imitazione dei classici, anche nel trattare argomenti sacri e spirituali.

${ }^{48}$ Francesco Bausi, “Ugolino Verino, Savonarola e la poesia religiosa...” op. cit.: 135. 



\title{
Luís da CRUZ E COMPANHIA NA CORRESPONDÊNCIA DE Manuel Correia
}

\author{
Manuel José de Sousa Barbosa \\ Universidade de Lisboa
}

Este estudo mais não pretende ser do que uma mera sensibilização para um estudo mais aprofundado do nosso humanismo nos finais do século XVI e inícios do XVII, um século após o tempo em que haviam pontificado figuras bem sonantes que projectaram além fronteiras o nome do nosso país. Lembremo-nos só, entre outros, de Henrique Caiado e do aveirense Aires Barbosa, este último aqui evocado hoje duma forma especial.

Em finais do séc. XVI, o humanismo continuava a florescer mas, como não podia deixar de ser, com outros cambiantes, fruto de novas circunstâncias históricas. A abordagem e recuperação do legado literário da Antiguidade greco-latina efectuada durante o séc. XV sobretudo em Itália, donde irradiava para o resto do continente europeu, prosseguiu no séc.XVI, mas agora associada a constrangimentos sociais específicos que afectaram praticamente toda a Europa. Refiro-me, claro está, às repercussões sociais advindas dos movimentos da Reforma e Contra-reforma, que transbordaram ainda para o século XVII. O movimento humanista, porém, enquanto busca de modelos de imitação na Antiguidade greco-latina, prosseguiu dos dois lados da barricada da Fé cristã. Se os dogmas provocavam divisões que não deixariam de se reflectir em certos aspectos da abordagem dos autores antigos, comum continuava a ser a crença, num e noutro lado, na importância da leitura desses autores. A literatura antiga constituía sempre um terreno que compensava explorar e dar a explorar.

Que se passava então em Portugal em finais do século XVI no que ao movimento humanista diz respeito? Será que pouco há a investigar, impondose antecipadamente, como desencorajadora de tal investigação, a perspectiva duma paisagem pouco variada, onde os Jesuítas ocupariam na prática toda a cena, prometendo de lá não sair tão cedo? De facto, nesta altura, o ensino está, em grande parte, em suas mãos, com uma rede bem espalhada de colégios nas principais cidades, ${ }^{1}$ e um método pedagógico solidamente implantado. ${ }^{2}$

\footnotetext{
${ }^{1} \mathrm{Na}$ transição do século XVI para o XVII, os Jesuítas possuíam colégios em Coimbra, Lisboa, Évora, Porto, Braga, Bragança, Faro, Santarém, Funchal, Angra, Luanda, Goa e Macau. Sobre esta matéria, cf. Lúcio Craveiro da Silva, "Os Jesuítas e o ensino secundário”, Brotéria, 31, 1940, 476-486; Francisco Rodrigues, História da Companbia de Jesus na assistência de Portugal, Porto, 1931-1950 (7 vols.), II, pp. 11-46.

${ }^{2}$ Estamos a referir-nos ao Ratio studiorum ("Plano de estudos" / "Método de estudos") consagrado como a magna carta do ensino nos colégios dos Jesuítas em 1599, após uma fase de sucessivas experimentações partilhadas e reflectidas ao longo de quase meio século.
} 
Os testemunhos deste humanismo escolar jesuíta sobrevivem em colecções de códices, geralmente incompletas, relativas aos vários colégios, códices esses que constituem, na sua essência, um repositório de composições poéticas e

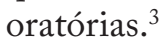

É inegável que na transição do séc. XVI para o XVII o humanismo português tinha na Companhia de Jesus a grande protagonista, com uma força que irradiava além fronteiras. Da gramática do P. Manuel Álvares e da sua intensa utilização em todo o mundo, com incontáveis edições, nem vale a pena falar, por ser questão sobejamente conhecida. ${ }^{4}$ Luís da Cruz é outra figura em evidência. A sua fama de grande poeta estava já consolidada internacionalmente, e ainda nem publicara o seu teatro. Acabara de editar, no ano de 1597, em Ingolstadt a sua Interpretatio poetica dos Salmos, obra que conheceria de imediato grande sucesso na Europa, como facilmente se conclui pelo número de reedições que mereceu em pouco tempo, em diversas cidades. ${ }^{5}$ Esta obra veio à luz com o elogio dum reputado humanista, Marco António Mureto, a quem se pedira parecer para a publicação da obra, tendo ele deixado registado que os ritmos eram simples, harmoniosos e muito agradáveis ao ouvido. ${ }^{6}$ Quanto à sua obra teatral, ela viria, como se sabe, a ser editada em Lyon em 1605, na oficina de Horácio Cardon. ${ }^{7}$

Mas não ficou por aqui a atenção dada a este grande expoente do humanismo escolar jesuíta em Portugal. Luís da Cruz cultivou a poesia em várias vertentes: paráfrase bíblica, lírica de tipo horaciano, ${ }^{8}$ epigramas, enigmas e, sobretudo, o teatro, nos subgéneros da tragédia, da tragicomédia, da comédia

${ }^{3}$ Do Colégio das Artes de Coimbra conhecemos os vários tomos das Rerum Scholasticarum, hoje dispersos pela Biblioteca Nacional de Portugal (cod. 3308, o "tomus primus"), pela Biblioteca Geral da Universidade de Coimbra (Cod. 993, o "tomus secundus", e o Cod. 994, o "tomus quintus") e pelos Arquivos Nacionais da Torre do Tombo (Livraria, Cod. 1963, o "tomus sextus"). Do Colégio de Évora restam igualmente alguns tomos duma série intitulada "Acta publice in Academia Eborensi" a que se ligam os códices CVIII/2-7 e CVIII/2-8, da Biblioteca Pública de Évora, e o Cod. 4515, da Biblioteca Nacional de Portugal.

${ }^{4}$ Podemos ver nos vols. XIII e XIV da revista Humanitas, em apêndice, o quadro compilado de Sommervogel pelo P. ${ }^{e}$ Emílio Springhetti, que regista quinhentas e trinta edições em vinte e dois países, incluindo o México, a China e o Japão, fora da Europa.

${ }_{5}$ Interpretatio poetica latine in centum quinquaginta psalmos, autore Ludouico Crucio Olysipponensi. Ingolstadii, excudebat Adam Sartorius. Anno M.D.XCVII. A esta editio princeps seguir-se-iam as edições de Madrid (1600), de Nápoles (1601), de Milão (1604) de Veneza (1604) e de Colónia (1612).

${ }^{6} \mathrm{C}$. prefácio inédito “Ad beneuolum eruditumque lectorem”, §21 in Manuel Barbosa, "Luís da Cruz e a poética teatral dos Jesuítas: o prefácio que ficou inédito" Euphrosyne 28 (2000), p. 401.

${ }^{7}$ Tragicae comicaeque actiones a Regio Artium Collegio Societatis IESV, datae Conimbricae in publicum theatrum, auctore Ludouico Crucio eiusdem Societatis olisiponensi, nunc primum in lucem editae et sedulo diligenterque recognitae. Cum privilegio. Lugduni, apud Horatium Cardon, 1605.

${ }^{8}$ Podemos incluir a paráfrase bíblica na lírica de tipo horaciano, uma vez que na sua Interpretatio os salmos são vertidos em metros horacianos. 
e da écloga. ${ }^{9}$ No domínio da prosa conhecemos-lhe dois discursos em louvor da Rainha Santa Isabel, os prefácios poéticos ao seu teatro e o De uita et moribus Dominici, uma biografia em três livros do Irmão Domingos João. ${ }^{10}$ Estou em crer que esta biografia, de que pouco se fala, terá sido a primeira obra de Luís da Cruz a merecer tradução em português, por obra do P. Francisco Macedo. ${ }^{11}$ No elenco das suas obras manuscritas indicadas no Sommervogel, relativas ao tempo em que ainda era Jesuíta e estava em Coimbra, surge a seguinte indicação: Vita Dominici Ioannis, e Societate Iesu, Laici Adjutoris. (En latin et en portuguais.). ${ }^{12}$

O grande trabalho literário de pedagogo desenvolvido por Luís da Cruz iria ter continuação nos tempos mais próximos, dentro da Companhia de Jesus, na obra de discípulos seus, e não apenas no campo teatral, em que merecem referência os nomes de João da Rocha e de Afonso Mendes, futuro Patriarca da Etiópia, ${ }^{13}$ mas igualmente no domínio da retórica e da oratória, com a figura cimeira do Padre Francisco Mendonça, célebre sobretudo pelo seu viridarium. ${ }^{14}$

Desviando-me, porém, do que já é mais ou menos do domínio público, vou enveredar agora por sendas menos visitadas, dando a Luís da Cruz a companhia de Manuel Correia e de Justo Lípsio. Deste último, todos sabemos ser uma das figuras marcantes, se não a mais marcante, do humanismo europeu de finais do século XVI que irradiava na altura na região flamenga. $\mathrm{O}$ seu

${ }^{9}$ Sobre os escritos de Luís da Cruz, impressos e manuscritos, cf. relação apresentada em Luís da Cruz, Teatro, Tomo I: Sedecias, estabelecimento do texto latino, introdução, tradução, notas e comentário de Manuel José de Sousa Barbosa, Imprensa da Universidade de Coimbra, 2009, pp. $9-14$.

${ }^{10}$ Texto manuscrito em ARSI, Lus. 59, fls. 5-98. Como se conclui da leitura dos fls. 32r-33r, este Irmão Domingos João, um leigo coadjutor temporal, teve uma acção determinante naqueles dias de balbúrdia no Colégio das Artes, anteriores à memorável representação da tragédia Sedecias e coincidentes com a estadia de D. Sebastião em Coimbra, em finais de Outubro de 1570. Cf. Luís da Cruz, Teatro...cit. pp. 45-48.

${ }^{11}$ Nascido em Botão, no ano de 1596, entrou na Companhia de Jesus em 1610. Mais tarde ingressou nos Franciscanos e foi o célebre Frei Francisco de Santo Agostinho de Macedo, que em França e Itália espantou as gentes com o seu saber enciclopédico.

${ }^{12}$ Cf. Carlos Sommervogel, S. I., Bibliothèque de la Compagnie de Jésus, Bruxelles, 1890-1909, s. u. «Macedo, François », col. 245-246.

${ }^{13}$ João da Rocha compôs a écloga Marsyas (1616) e a tragicomédia Daniel Sapiens honestatus (1616); Afonso Mendes compôs a Tragicomédia São Paulino, Bispo de Nola (1604). Além do que, sobre estes nomes, vem referido em Claude-Henri Frèches, Le Théâtre neo-latin au Portugal (1550-1745), Paris, Librairie A. G. Nizet - Lisbonne, Bertrand, 1964, pp. 131, 434-447, 458465, cf. ainda Sebastião Tavares de Pinho, "O Colégio das Artes da Universidade de Coimbra, e a tradição clássica no início do século XVII”, Biblos, 68 (1992) 47-76.

${ }^{14}$ P. Francisco de Mendonça, Viridarium sacrae et profanae eruditionis. Lugduni, Jacob Cardon, 1632. Trata-se duma obra de concepção barroca, uma monumental recolha cujos conteúdos recolhidos de obras de autores profanos e sagrados surgem dispostos simbolicamente por diversas zonas dum jardim ou vergel (lat. uiridarium). 
percurso de vida é curioso: educado inicialmente pelos Jesuítas, viajou depois pelo Luteranismo e pelo Calvinismo, fase a que se associa uma presença marcante na Universidade de Leiden, acabando depois, já no final da vida (viria a falecer em 1606), por regressar à ortodoxia católica e ensinar na Universidade de Lovaina, cidade à qual, num gesto simbólico, doou o seu próprio coração. Ao contrário de Justo Lípsio, Manuel Correia é uma figura obscura, de que pouco se fala. No verbete que Barbosa Machado lhe dedica na sua Bibliotheca Lusitana, ficamos a saber que era natural de Elvas, que se licenciou em Direito Canónico ("em os Sagrados Canones"), que era "Examinador Sinodal do Arcebispado de Lisboa e Parocho da Igreja de S. Sebastião da Mouraria" e que "teve estreita amizade com o insigne Luis de Camoens a cuja instância ilustrou com eruditos Comentários o seu Poema dos Lusiadas". ${ }^{15}$ Das outras suas obras, terão ficado manuscritas os seus Princípios de Gramática e Cornélio Tácito traduzido em português. Barbosa Machado refere ainda o facto de, devido à sua "erudição historica e poetica" ter merecido "a correspondência de varoens famosos, entre os quais se distinguiu o célebre filólogo Justo Lípsio". Porém, sobre a sua correspondência inédita em que baseio este meu estudo, não surge qualquer referência.

Uma parte desta correspondência inédita encontra-se no códice da British Library Sloane 902, que contém a segunda centúria da correspondência de Manuel Correia, organizada pelo próprio, como se pode ver quer no título, quer na carta introdutória que se lhe segue, endereçada a Nuno Álvares de Portugal. ${ }^{16}$ Nessa carta introdutória, o autor solicita um parecer sobre a hipótese de mandar imprimir esta centúria de cartas. Manuel Correia alega nunca ter sido essa a sua intenção, mas que as insistências dos amigos acabaram por convencê-lo do interesse da publicação da sua correspondência, pelo que necessita da sua opinião. ${ }^{17}$ Conclui-se das suas palavras que já teria organizado, nos mesmos moldes, uma Centuria prima.

Nesta centena de cartas, distribuídas cronologicamente entre Julho de 1600 e Agosto de 1601, deparamos com uma série de nomes que remetem para vários quadrantes da alta sociedade de então. De destacar, além do já referido Nuno Álvares de Portugal, são os nomes dos Jesuítas Luís da Cruz e Álvaro Lobo, o de Diogo Paiva de Andrade, conhecido humanista autor das

\footnotetext{
${ }^{15}$ Estes comentários aos Lusíadas foram impressos duas vezes, uma primeira em 1613 e uma segunda em 1720 .

${ }^{16}$ Filho do $2^{\circ}$ Conde de Vimioso. Do partido Filipino. Foi presidente do Senado da Câmara de Lisboa e Governador sob o reinado de Filipe III.

${ }^{17}$ Ecce alteram epistularum centuriam, secundam scilicet. Mitto eam tibi, Nune generose, eadem prorsus lege, qua primam, ut legas, ac relegas; et lentissime uideas, an sit typis tradenda, ut clamat amicorum /2v/turba. Non id meum consilium, non ea fuit unquam mens (audiuisti ex me iam millies) sed flagitant amici, immo urgent. - British Library, Sloane 902, fl. 2r-2v.
} 
tragédias Eduardus e Ioannes Baptista e do poema épico Chauleida, entre outros escritos, ${ }^{18}$ o de Manuel de Sousa Coutinho, o futuro Frei Luís de Sousa, mas nesta altura bem arreigado na vida secular, ${ }^{19}$ e, por fim, para só me deter nos ilustres, o nome de um dos mais famosos músicos portugueses, de quem se diz que rivalizou com Palestrina e que morreu com a bonita idade de 103 anos. Refiro-me a Duarte Lobo, a favor de quem Manuel Correia intercede, mais de uma vez, nesta correspondência, em cartas para João Moreto, possivelmente apoiando a publicação das suas obras na imprensa Plantiniana. ${ }^{20}$

Só uma leitura exaustiva deste epistolário poderá dar conta de todos os episódios contidos nesta correspondência, cada um deles correspondendo a um núcleo de várias cartas, com os seus interlocutores desempenhando um papel específico. Não vos falo a partir dessa leitura exaustiva. Cheguei a este texto manuscrito apenas movido, inicialmente, pelo desejo de saber alguma coisa mais de Luís da Cruz, após ter observado que, na sumária referência que o Iter italicus ${ }^{21}$ apresenta deste códice da British Library, o nosso Jesuíta aparece aí em muito boa companhia. Justo Lípsio foi o nome que desde logo me chamou a atenção. Como se sabe, Lípsio surgia em finais do séc. XVI como a figura mais proeminente dum vigoroso movimento humanista que irradiava na altura nos Países Baixos. Esse humanismo flamengo reorientava de certo modo a leitura dos autores antigos privilegiando novos modelos, vistos como inspiradores de respostas mais fecundas para os novos tempos. $\mathrm{O}$ centro de gravidade dessa leitura deslocava-se dos autores da época de ouro da literatura latina (Cícero e Virgílio, sobretudo) para autores duma certa periferia, como Plauto, e outros ligados à literatura da época imperial, como Séneca e Tácito. As edições promovidas por Lípsio falam bem dos autores de leitura privilegiada por esta corrente humanista. ${ }^{22}$ À emergência de Tácito, por obra de Justo Lípsio, como o historiador da Antiguidade que melhor poderia inspirar a política de então, associou-se a preponderância dum estilo rebuscado e difícil onde pontuava o gosto pelo arcaísmo e pela erudição. Este epistolário constitui, neste aspecto,

${ }^{18}$ Sobrinho de Diogo Paiva de Andrade (1528-1575), teólogo ilustre, enviado ao Concílio de Trento por D. Sebastião.

${ }^{19}$ Acabara de ser nomeado para capitão-mor de Almada e estaria em vias de incendiar aí uma das suas casas, para impedir que nela se alojassem os governadores do reino, fugindo à peste que grassava, precisamente nesta altura, em Lisboa. É possível que o episódio histórico do incêndio da sua própria casa, em Almada, mereça referência numa das seis cartas que lhe são endereçadas nesta correspondência. $\mathrm{O}$ que se pode dizer é que o seu nome surge muito ventilado na correspondência entre Manuel Correia e Nuno Álvares de Portugal.

${ }^{20}$ Como se pode ler na Biblioteca Lusitana, a Arte da Musica de Duarte Lobo, editada em 1603 na tipografia acabada de referir, contém versos de Manuel Correia de elogio ao autor.

${ }^{21}$ P. O. Kristeller, LatinManuscript Books Before 1600: A List of the Printed Catalogues and Unpublished Inventories of Extant Collections. Munich, 1993.

${ }^{22}$ Séneca, Plínio-o-Moço, Tácito, Juvenal, são alguns dos nomes que mereceram os cuidados filológicos de Justo Lípsio. 
um testemunho da chegada do Lipsianismo também ao nosso país. Lípsio tinha aqui os seus admiradores, e Manuel Correia era um deles, como iremos ver, e tinha aqui também os seus críticos, como seria o caso de Luís da Cruz, em paralelo com o que se passaria na mesma altura nos sectores humanistas da Companhia de Jesus.

Da voga desta corrente lipsiana do humanismo dá conta Luís da Cruz no prefácio ao seu teatro que acabaria por ficar inédito, intitulado ao leitor erudito e benévolo, substituído pelo que surge na edição de Lyon, com um título ligeira mas significativamente modificado: Ao leitor benévolo e amigo. Este não inclui qualquer menção explícita a Lípsio e aos lipsianos, bem ao contrário daquele, todo ele assente na preocupação do dramaturgo de se defender contra eventuais críticas que lhe adviriam de determinados eruditos que o acusariam de não seguir as tendências mais em voga na altura, protagonizadas por Lípsio e pelos seus seguidores. Daí que este prefácio inédito, na sua forma epistolar, apresente um discurso bem estruturado em que, após um exórdio dedicado à importância do papel dos críticos na análise da boa literatura, o dramaturgo enuncia, no que se pode considerar a partitio, os principais pontos polémicos eventualmente suscitados pelo seu teatro, em cuja defesa se lança depois. ${ }^{23} \mathrm{E}$ sobretudo no que diz respeito ao estilo que a referência explícita ao lipsianismo em voga mais se faz notar. Após nos colocar perante a interpelação dos críticos que lhe perguntam pelos vestígios da expressão arcaica, cuja inexistência desvalorizaria imediatamente a obra aos olhos dos eruditos da actualidade e cujo cultivo grangearia ao seu autor não apenas autoridade mas também a amizade dos homens mais eruditos da Holanda, Luís da Cruz defende-se dizendo não ser forçoso que a sua obra rescenda a antiguidade. Chama em sua defesa Cícero, que afirma, em Orator 36, que

"No domínio da pintura uns deleitam-se com o que se apresenta grosseiro, descuidado, misterioso e opaco, enquanto outros com o que se mostra brilhante, risonho e luminoso, não havendo meio de exprimir por que normas ou fórmulas cada coisa se torna excelente no seu próprio género." ${ }^{24}$

Apesar de Lípsio e os Lipsianos procurarem imitar as rudezas do estilo arcaico e de lhes não negar mérito nisso, Luís da Cruz confessa optar pelo estilo harmonioso e agradável que usou na sua Paráfrase dos Salmos, e que lhe mereceu o elogio de Marco António Mureto, patente no parecer emitido previamente à edição da obra. Afirma Luís da Cruz:

${ }^{23}$ Cf. texto latino deste prefácio, acompanhado de tradução, em Manuel Barbosa, "Luís da Cruz e a poética...”, cit., pp. 384-405.

${ }^{24}$ In picturis alios horrida inculta, abdita et opaca, contra alios nitida laeta conlustrata delectant. Quid est quo praescriptum aliquod aut formulam exprimas, cum in suo quidque genere praestet. 
"Eu confesso ter seguido um tipo de escrita que, não sendo, quanto a mim, desprovido de energia, resulta musicalmente bem constituído. Por isso, tal como deixamos àqueles excelentes homens o hiato e também o encontro de vogais, com a desaprovação também de Marco Túlio, não é por isso que sentimos repugnância em relação a eles, mas confirmamo-los como dignos do seu mérito." ${ }^{25}$

Este prefácio foi escrito pelo menos após 1597, ano da edição da sua Interpretatio Poetica dos Salmos, aludida no prefácio, como acabamos de ver, e certamente depois de 26 de Julho de 1601, data da última carta desta centúria epistolar de Manuel Correia. A ausência de qualquer referência ao seu trabalho de revisão dos textos teatrais neste núcleo de correspondência assim nos faz pensar. Em todo o caso, a defesa do seu teatro contra eventuais reparos críticos advindos dos eruditos lipsianos será certamente reflexo do debate literário em curso, no qual a Companhia se erguia então na defesa do ideal ciceroniano de eloquência, contra a doutrina dos engenhosos aticistas e anti-ciceronianos, na linha, aliás, do que viria a ser testemunhado nas Prolusiones Academicae do Jesuíta Famiano Strada, obra editada em 1617. ${ }^{26}$

Mas regressemos à Centuria Secunda do epistolário de Manuel Correia. Envolvem-se nesta correspondência, como de certo modo já ficou sugerido acima, o que podemos considerar a elite do nosso humanismo naquela altura, gente socialmente bem colocada, amante da cultura literária grecolatina e que, nuns casos mais que noutros, faz avultar nos textos destas cartas, maioritariamente remetidas por Manuel Correia, mas não só, múltiplas marcas da leitura dos antigos. Luís da Cruz é, obviamente, um desses casos de escrita epistolar recheada de alusões a passos da literatura antiga, predominantemente latina, mas também grega. Este círculo de humanistas compraz-se em partilhar questões de erudição literária, lado a lado com outras questões emanadas da banalidade do quotidiano, mas umas e outras tratadas sempre num clima de afectuosa cordialidade que nos faz pensar em Plínio-o-Jovem como o principal modelo aqui subjacente. ${ }^{27}$ No que respeita a questões da vida quotidiana,

${ }^{25}$ Texto latino Ibid., p. 401.

${ }^{26}$ Famiani Stradae Prolusiones Academicae, Romae, apud Mascardum, 1617. Sobre o papel desta obra, cf. Marc Fumaroli, L'Âge de l'éloquence: Rhétorique et "res liraria de la Renaissance au seuil de lépoque classique, Paris, Albin Michel, 1994, pp. 190-202.

${ }^{27}$ A este estilo epistolar, convém referi-lo, não será alheia também uma propositada revisão final do autor, com retoques aqui e ali, mesmo em cartas que não fossem suas, tendo em conta a sua eventual publicação, o que constituía prática habitual dos humanistas. Assim terá feito Justo Lípsio, na preparação das suas centúrias epistolares. Cf. Iusti Lipsi Epistolae, pars I: 1564-1583. Curauerunt A. Gerlo - M. A. Nasnwelaerts - H. D. L. Vervliet. 1978, Paleis Der Academien Hertogsstraat: Brussel, p. 14. 
refira-se, por exemplo, o nascimento dum filho a D. Nuno Álvares de Portugal, facto que é celebrado por Manuel Correia com uma composição poética. ${ }^{28}$ A esta e outras composições de poesia episódica espera-se uma apreciação na carta de resposta. Ao mesmo Nuno Álvares de Portugal agradece Manuel Correia uma água que aquele lhe enviou e que resultou muito benéfica para os seus olhos. ${ }^{29}$ Aqui e além, nesta correspondência, pode o leitor surpreender-se com a menção de factos que terão alarmado a sociedade na altura, como o que vem referido na carta 78, ${ }^{30}$ dirigida a Luís da Cruz.

Passo a narrar. Já Manuel Correia acabara de dobrar a carta quando the chega a notícia dum caso espantoso de travesti na cidade de Lisboa, notícia que ele se apressa a incluir ainda na carta, como post scriptum. O caso era o seguinte: uma mulher ousara, três anos a fio, passear-se vestida de homem em plena cidade de Lisboa, em companhia de figuras respeitabilíssimas, usando o nome de Manuel de Sousa Coutinho e, nota interessante, frequentava os mosteiros, os ginásios e colóquios públicos (colloquia publica), levada por homens da alta sociedade, que Manuel Correia prefere silenciar por consideração para com as pessoas (bonestatis causa), e cometia, ao que dizem, actos abomináveis que se envergonha de referir (quae pudet referre). Este formoso e delicadinho adolescente (formosulus iste adolescentulus, et delicatulus) acabou por ser preso e entregue ao Juiz dos assuntos criminais, Gregório de Oliveira que, tal como o verdadeiro Manuel de Sousa Coutinho, é também aqui um dos correspondentes de Manuel Correia.

Mas, obviamente, é o aspecto da erudição literária que mais caracteriza e valoriza esta correspondência. Manuel Correia, por exemplo, eufórico com a correspondência encetada com Justo Lípsio, informa disso alguns dos seus amigos, enviando-lhes cópias das cartas e solicitando-lhes opiniões sobre o teor delas. ${ }^{31} \mathrm{~A}$ um tal D. Damião de Aguiar, destacado membro das cortes, há uma referência a Buchanan, de certo modo inesperada, dada a fama de herético que sobre ele corria. Não apurei todo o significado desta referência, lendo outras cartas do mesmo núcleo, ou seja, do que liga Manuel Correia a Damião de Aguiar. O texto latino, na tradução que lhe faço, dirá mais ou menos o seguinte:

Buchanan está presente apenas com as cartas dos amigos. Envio-tas para que vejas toda a importância que o mundo dá a um homem quase desconhecido nesta cidade. Desconbecido, digo, dos que desconbecem a virtude e o talento. ${ }^{32}$

\footnotetext{
${ }^{28}$ Carta 61: Cf. BL, Sloane 902, fl. 42r-v.

${ }^{29}$ Carta 80: Ibid. fl. 59-r-v.

${ }^{30}$ Ibid., fls. 57 r-59r.

${ }^{31}$ É o que sucede, por ex., na carta 39, endereçada a Luís da Cruz: “(...) Nunc Iusti Lipsii epistulas, alteram ad me, ad Nunum Mendozium alteram, discipulum olim nostrum, nunc Brusselae cum Alberto Principe commorantem, tibi mitto legendas; ut quid tibi uideatur Belga ille, respondeas." (Ibid. fl. 25v).

${ }^{32}$ Bucananus adest cum epistulis amicorum dumtaxat. Has mitto tibi, ut uideas quanti faciat orbis
} 
Mas outros nomes, neste caso de autores clássicos, atestam a erudição que perpassa esta correspondência, revelando a qualidade deste sodalício literário. Cícero, Virgílio, Boécio, Marcial, Horácio e outros afloram várias vezes no discurso, sublimando-o com um toque de autoridade. E não apenas autores latinos, mas também gregos, citados em grego, como aquela máxima do comediógrafo Filémon, preservada no florilégio de Estobeu:

\section{Assim é a vida do homem: alegramo-nos menos do que sofremos. ${ }^{33}$}

Para Manuel Correia, este convívio literário, este sodalicium, como o designa, representa o que ele tem de mais caro na vida. Lípsio e Luís da Cruz surgem aí como aqueles que, pela sua celebridade, mais o honram. Um conjunto referências disseminadas por esta correspondência assim o confirma. Eis algumas. Logo no início da segunda carta, endereçada a Frei Álvaro Leitão, Provincial da Ordem dos Pregadores, pode ler-se: Eis as cartas para ti. O mundo conhece Lipsio e Cruz; a nós, nem sequer o recanto mais pequeno da nossa cidade. ${ }^{34}$ A Nuno Mendonça, seu antigo aluno, actualmente a prestar serviço militar em Bruxelas como mestre de campo junto do Príncipe Alberto, fala sobre o dramaturgo jesuíta nos seguintes termos:

É o famoso Cruz, muito conceituado entre aqueles eruditos padres, de grande reputação. Editou recentemente uma obra, a Paráfrase aos salmos de David. Talvez já a tenhas lido. E prepara-se para uma outra, este varão erudito e muito meu amigo. Trocamos correspondência um com o outro. ${ }^{35}$

Mais à frente, na carta 60, exultante por tanto Lípsio como Luís da Cruz o honrarem respondendo às suas cartas, proclama, eufórico:

Sim, verdadeiramente sou um homem feliz, naquela zona fecunda dos sentimentos em que amamos. Com efeito, a quem aconteceu alguma vez tal convívio de amigos, tal amizade? Dum lado, Lípsio, o pélago das letras; do

hominem hac in urbe uix notus, ab illis dico, qui uirtutem nesciunt et ingenia. (Ibid. fl. 38v).

${ }^{33}$ Toiouto o bios anthropou, euphainometha ellaton, e lypoumetha Ibid. fl. 25v. Neste fragmento de Filémon inclui-se o vocativo gyne, após anthropou aqui omitido. Cf. Poetae Comici Graeci, edd. R. Kassel et C. Austin, Berlim, Walter de Gruyter, 1989, vol. VII, p. 301. Filémon, que viveu entre 368/69 e 267/63 a. C. integra-se na chamada "comédia nova". Estobeu, escritor grego do séc. $V$, autor dum importante florilégio de máximas, que viria a merecer tradução latina pela primeira vez no séc. XVI, pelo suíço Conrad Gesner.

${ }^{34}$ En epistulas tibi. Lipsium, et Crucium nouit orbis, nos ne minimus quidem urbis nostrae angulus. (Cf. BL, Sloane 902, fl. 2r).

${ }^{35}$ Est Crucius ille inter illos eruditos patres magni nominis. Recens nunc opus edidit in Dauidicos Psalmos Paraphrasim, legisti iam fortasse, ad aliamque accingitur uir eruditus, et amantissimus mei. Scribimus inuicem. (Ibid. fl. 22v). 
outro, Cruz, produzido pelas Musas; depois estão outros seiscentos, todos excelentes, cada um à sua maneira. ${ }^{36}$

E prossegue dizendo que não trocaria uma situação destas nem pelo ouro, nem pelo auge da fortuna, nem pelo ceptro duradouro do poder nem pela tiara pontifícia. $\mathrm{Na}$ carta 78 , ainda sobre esta constelação de eruditos afirma: Realmente, nada há de mais sério para mim do que este sodalício de amigos, no qual eu construo de preferência os livros. ${ }^{37}$

No que diz respeito à correspondência com Justo Lípsio, foi Manuel Correia a tomar a iniciativa de lhe escrever, como o próprio revela, após muito tempo de hesitação, inibido pela suprema autoridade da pessoa que admirava à distância. ${ }^{38} \mathrm{O}$ pretexto facilitador desta tomada de resolução foram duas cartas que lhe chegaram de Nuno Mendonça: uma remetida por este, e outra de Justo Lípsio para Nuno Mendonça. Da carta de Manuel Correia para Justo Lípsio passo a ler o seguinte excerto, por si só revelador do entusiasmo e do interesse que a personalidade de Justo Lípsio despertava em Manuel Correia e no seu círculo de amigos:

Felicito-te pois, varão eruditíssimo, em nome dos Portugueses, pela índole notabilíssima do teu espírito, pela tua enorme generosidade para com todo o mundo e sobretudo para com esta nossa parcelazinha da remota Hispânia que tanto se apascenta dos teus livros, tanto os aprecia e de certo modo deles se alimenta e vive, que julga que as tuas obras apenas em atenção a ela foram elucubradas, apenas em atenção a ela vieram à luz do dia. E a tal ponto estão os Lusitanos afeiçoados ao nome de Lípsio que tenho a suspeita de que, alterando a sua designação de origem, se poderiam chamar Lipsianos. ${ }^{39}$

$\mathrm{Na}$ carta de resposta, enviada através do já referido Nuno Mendonça, Lípsio agradece a Manuel Correia todas as cortesias contidas na carta deste, confessa não estar no pedestal em que ele o coloca mas perdoa-lhe este erro de apreciação, cometido por simpatia. Elogia, além disso, a gente lusa, muito célebre não apenas nas armas mas também nas letras. E no que se refere a

${ }^{36}$ Nam ego felix homo sum, felici illa dico animorum parte qua amamus. Cui enim umquam tale contigit amicorum sodalitium, talis amor? Hinc Lipsius literarum pelagus, illinc Crucius a Musis factus, inde sexcenti adsunt alii, suo quisque modo, praecellentes. (Ibid. fl. 41r).

${ }^{37}$ Nibil enim mibi magis serium, quam amicorum sodalitium, in quo potissimum libros constituo. (Ibid. fl. 58r).

${ }^{38}$ Huic operi millies iam manus apposuissem (...) nisi - quod certius est - binc ingenii nostri tenuitas, illinc Lipsii deterreret auctoritas (Iusti Lipsii Epistolae, pars XIII: 1600, curauit Jan Papy. Paleis Der Academiën - Hertogsstraat 1, Brussel, 2000, p. 166). Esta carta, com a data de 1 de Junho de 1600, não integra a Centuria II de Manuel Correia. Possivelmente incluir-se-ia na Centuria I, cujo paradeiro se desconhece.

${ }^{39}$ Gratulor igitur tibi, uir doctissime, Lusitanorum nomine praeclarissimam animi tui indolem, largissimam in totum terrarum orbem munificientiam maximeque in hanc nostram extremae Hispaniae regiunculam, quae ita libris tuis pascitur, it a fruitur et certo quodam modo alitur et uiuit, ut sibi tantum elucubrata, sibi tantum edita fuisse opera tua existimet. Adeoque in Lipsii nomen affecti sunt Lusitani, ut mibi suspicio sit fore aliquando ut originis nomine immutato Lipsiani appellentur. (Ibid., p. 167). 
estas, os frutos que elas têm dado, duma forma que não se vê em nenhum outro rincão de Espanha, mostram que os Portugueses conservam bem vivo o fogo da cultura literária primeiramente aceso em suas terras por Sertório. Fala ainda do gosto que teria em visitar a Lusitânia e conhecer as suas gentes, se para tal houvesse condições, o que não sucede devido à guerra. Termina com uma série de expressões afectuosas que Barbosa Machado deixou registadas na notícia que lhe consagra: Te, mi Correae, uideam, pectori applicer, collo adstringar, atque ipsa hac cogitatione liquesco, et moueor: quid si re frui detur? (Pudesse eu ver-te, meu caro Correia, abraçar-te, agarrar-me ao teu pescoço, e só com este pensamento desvaneço-me e deixo-me comover. E se nos for dado desfrutar deste acontecimento?). ${ }^{40}$

Nesta Centuria II de Manuel Correia, na carta 91, está registado um segundo momento de troca de correspondência. Lípsio informa Manuel Correia que acaba de editar a Centuria III das suas cartas, de que lhe enviará um exemplar. Termina a sua breve carta com referências ao seu estado de saúde (sente-se a enfraquecer: languor) e ao descanso eterno, cuja iminência já pressente e para o qual se prepara. ${ }^{41}$ A resposta de Correia (carta 99), em cujo comentário não me vou alongar, glosa o topos da orfandade pela perda dum amigo, tece considerações sobre a vida eterna e termina dizendo da sua muita ansiedade por receber a referida centúria de cartas acabada de editar. ${ }^{42}$

\section{Manuel Correia e Luís da Cruz}

A correspondência entre estas duas figuras vem testemunhada nesta centúria em sete cartas, quatro de Manuel Correia e três de Luís da Cruz e, como o sugere a primeira delas, de Manuel Correia, dá continuidade a uma prática anterior, testemunhada certamente na Centuria I, e promete continuidade, o que nos remeteria para uma eventual Centuria III, cuja existência ignoramos de todo. Como já referi, Barbosa Machado, na sua Bibliotheca Lusitana, não faz menção de qualquer centúria epistolar que tenha ficado manuscrita.

Não pretendo fornecer aqui uma relação exaustiva das questões ventiladas na correspondência entre estas duas figuras. Uma série de temas perpassam nestas sete cartas, articulando-as de forma interessante. A relação que aqui vou dar, respeitando a sucessão cronológica das cartas, não é exaustiva. A narração que segue, algumas vezes em estilo indirecto, articula uma história, através dos seguintes pontos, assim enunciados: a cegueira de Manuel Correia; a emenda de Marcial ou os olhos que o deverão ler; Justo Lípsio ou a erva curativa que devolve os mortos à vida.

\footnotetext{
${ }^{40}$ Cf. Ibid. pp. 275-277.

${ }^{41}$ BL, Sloane 902, fl. 65r-v.

${ }^{42}$ Cf. Ibid., Als. 89v-90v
} 


\section{$1^{\text {a }}$ carta (de 14 de Outubro de 1600): $:^{43}$}

Relata Manuel Correia a Luís da Cruz que a 3 de Setembro de 1600 saíra de casa, de manhãzinha, para assistir ao auto de fé que teria lugar nesse dia no átrio da Inquisição. Fizera-o a pedido dos amigos. Sucedeu porém que, olhando para os que saíam cobertos com as insígnias da heresia, reconheceu alguns que vira ainda na véspera passeando-se com roupas de seda e fazendo-se transportar em cavalos e mulas. Estupefacto e indignado com aquilo, regressou a casa e, na doçura da solidão, sozinho apenas para si, arrumou a escrivaninha e lançou-se ao trabalho que tinha entre mãos, ou seja, comentar Marcial. E, com uma grande disponibilidade mental que se traduziu em eficiência, deu conta só nesse dia de 60 epigramas. Porém, no fim, sentiu os olhos escurecerem, ficarem enevoados e como que cobertos por um véu. Assaltou-o o pânico. Recorreu a Deus, recorreu aos amigos, recorreu a médicos e cirurgiões. Cada um aconselhava uma coisa e ele pouco fazia, receoso que lhe acontecesse o que a outros acontecera com os excessos da cura: a extinção da luz vital. Fora esta a razão por que deixara de lhe escrever. Termina a carta pedindo a Luís da Cruz que ponha os seus amigos da Companhia a rezar por ele.

\section{$2^{\text {a }}$ carta (de 13 de Dezembro do mesmo ano): ${ }^{44}$}

Responde Luís da Cruz que se encontrava acamado quando lhe chegou a carta do amigo. Pensava encontrar nela um lenitivo para os seus próprios males mas, ao inteirar-se do conteúdo, ficou desolado e, para não lhe causar igualmente desolação, prescindiu de falar dos males que o haviam mantido acamado e optou apenas por consolar o amigo. A cegueira, reconhece Luís da Cruz, é de facto um mal bem cruel para os literatos, dado o uso que estes fazem dos olhos, mas há forma de a suportar. Que ele repare em Dídimo de Alexandria, o cego, tão forte em sabedoria e santidade que Jerónimo não hesitou em navegar até Alexandria para, junto dele, se aconselhar sobre questões que o seu espírito perspicaz não conseguia resolver. Neste mundo, todos representamos de certo modo uma tragédia. Manuel Correia poderá sentir-se um Édipo, mas não terá necessariamente de se mostrar um Róscio, exagerando em choros e lamentações. Pior cegueira do que a dele era a dos que Manuel Correia vira no auto de fé. A dele apenas lhe retardava a explicação de Marcial. Acha bem que pense dar brilho (lucem dare) a este poeta, de forma a que a juventude possa ler o que ele conserva de agudo e de erudito, mas só

\footnotetext{
${ }^{43}$ Carta 19 da Centuria II de Manuel Correia. Alertamos para que nem sempre a datação das cartas se harmoniza com a sucessão dos factos nelas relatados. Em apêndice, poderá apreciar-se, na íntegra, o texto latino das cartas trocadas entre Manuel Correia e Luís da Cruz.

${ }^{44}$ Carta 40 da Centuria II de Manuel Correia.
} 
depois de, com a foice da irrepreensível virtude, ter afastado para bem longe a perversidade e a luxúria. $\mathrm{O}$ que lhe aconteceu à vista talvez ensine que Marcial deverá ser lido com os olhos vendados, porque quem se ocupar dele com os olhos abertos, ficará contaminado pelo veneno da impudicícia. Boa sorte para este trabalho é o que lhe deseja, mas também contenção. Sessenta epigramas num dia apenas é demasiado; configura um caso de avidez nos estudos. Foi esta avidez que deu azo a esse obscurecimento imperceptível da visão. Que se lembre do passo da Eneida "Maturate fugam":45 a fuga tem rapidez mas também tem de ser refreada; ou então do velho ditado grego speude bradews, em latim Festina lente. ${ }^{46} \mathrm{E}$ quanto aos médicos, nada a fazer. Não nos curam sem de algum modo nos prejudicarem. Já Marcial sugere esta ambiguidade da medicina: Cem mãos me tocaram, geladas do Aquilão. Não tinha febre, Póstumo; agora tenho. ${ }^{47}$ Portanto, há que consultar os médicos. Que prepare o dinheiro. E Luís da Cruz fecha esta carta com um prémio de consolação (corollarium): dispõe-se a contribuir para o prazer e a honra do seu amigo escrevendo qualquer coisa, mas que seja este a apresentar o assunto, a provocá-lo.

\section{Resposta de Manuel Correia (de 5 de Janeiro de 1601): ${ }^{48}$}

No que à cegueira diz respeito, Manuel Correia está convencido de que caminha a passos largos para a perda de visão, e logo numa altura em que tanto precisava da vista para a explicação de Marcial. De Dídimo de Alexandria quer a literatura esmerada, mas quanto à cegueira que a tome quem quiser. Sobre Marcial, parece sossegar Luís da Cruz dizendo que acrescenta Marcial na parte em que ele é elogiável, digno de ser imitado. O seu esforço orienta-se no sentido de publicar este poeta muito erudito, purificado de todo o veneno, limpo de qualquer inconveniente. Termina referindo-lhe o envio de duas cartas de Justo Lípsio, para que as leia e dê a sua opinião sobre o homem. Eis matéria para a resposta, ou melhor, para o prémio de consolação prometido.

\section{Resposta de Luís da Cruz (em carta de 15 de Dezembro de 1600): ${ }^{49}$}

Se Dídimo não lhe agrada de todo, que se vire para Gregório que, pelo muito que fez apesar da sua bem frágil saúde, mereceu o cognome de Magno. Que peça a Deus constância de carácter e sobretudo paciência. Que a vista

\footnotetext{
${ }^{45}$ Virg., Ae. I, 141.

${ }^{46} \mathrm{E}$, em português, talvez "Devagar se vai ao longe" ou, de forma inversa, "Quanto mais depressa mais devagar”. Quanto ao provérbio grego, segundo Suetónio (August. 25) Augusto recorria a ele muito frequentemente, quer falando quer escrevendo.

${ }^{47}$ Cf. Marcial V, 9, 41, onde não surge Postume, mas Symmache. A alteração efectuada por Luís da Cruz esconde certamente motivação irónica.

${ }^{48}$ Carta 39 da Centuria II de Manuel Correia.

${ }^{49}$ Carta 59 da Centuria Secunda de Manuel Correia.
} 
lhe seja restituída, é o que lhe deseja, e ainda, já que recusa ser Dídimo, que supere em visão os linces, a bem do trabalho que tem em mãos. Mercê desse esforço, os Portugueses terão um português que fará com que não seja forçoso fazer vir de províncias estrangeiras quem explique Marcial, elegante mas obscuro. Que também ele, Luís da Cruz, de saúde igualmente frágil, todos os dias dá aulas e interpreta Daniel, ${ }^{50}$ além de fazer ainda frequentes pregações. Quanto a Lípsio, leu as cartas e confessa-se encantado com o facto de o seu amigo se corresponder com um varão tão erudito. E quanto à ideia de este visitar Portugal, será melhor dizer-lhe que não venha, ainda que possa. Viria encontrar a Lusitânia, não no seu apogeu, como era habitual, mas coberta e inutilizada pela desgraça da peste. Prefere saber que ele sofre na Bélgica a vêlo entristecer-se no meio da nossa desgraça. Quanto ao que pensa do homem, compôs o seguinte poema em hendecassílabos falécios: ${ }^{51}$

\section{Para Manuel Correia, sobre Justo Lípsio:}

Tendo tu há pouco solicitado ao teu amigo Cruz

Que elogio seria habitual dar a Lípsio,

Respondeu ele que Lípsio lhe parecia

A erva de Creta de folhas medicinais

Nascida para devolver a saúde aos feridos.

Estendiam-se nas encruzilhadas os homens de outrora

De cujas feridas todos se condoíam

E contudo os cirurgiões que, com mão Peónia, as trataram

Nada conseguiram com seus esforços.

Mas quando a velha doença experimentou

O sabor e o suco deste dictamno,

Fugiu de tal modo, Cura sagrada, que era

Dos que ocupavam as entradas

Como se tivessem fugido

Ao peso da passagem do tempo.

Que elogio farei a Justo? Oh! Do cimo do Ida

Rosa colhida no monte Dicte, vive!

Ao tocarem-te, os mortos regressarão à vida.

\footnotetext{
${ }^{50}$ Estaria Luís da Cruz a desenvolver uma paráfrase poética ao Livro de Samuel, à semelhança do que já fizera com os 150 Salmos da Bíblia. Esta informação condiz com um trecho duma carta de Manuel Correia a Nuno Mendonça, onde o mesmo é sugerido: Recens nunc opus edidit in Dauidicos Psalmos Paraphrasim, legisti iam fortasse, ad aliamque accingitur uir eruditus, et amantissimus mei. (Tradução: Editou recentemente a Paráfrase aos Salmos de David, talvez já tenhas lido, e prepara-se para outra, este varão erudito e muito meu amigo."). Cf. BL, Sloane 902, fl. 22v. O sublinhado é nosso.

${ }^{51}$ Como facilmente poderá verificar-se, o poema inspira-se no passo do livro XII da Eneida em que Vénus socorre, com o dictamno do Ida, Eneias ferido com uma seta, quando os médicos, com seus cuidados, não the podiam valer. Cf. texto latino do poema em "Apêndice", carta 59.
} 


\section{Resposta de Manuel Correia (em carta não datada): ${ }^{52}$}

Confessa-se exultante, felicíssimo com o círculo de amigos em que está integrado. A última carta de Luís da Cruz reconfortou-o e animou-o para trabalhos maiores, superiores às suas forças. Vai enviar Marcial para a fornalha, para que se estabeleça o mais rápido possível. E talvez a Marcial acrescente outro ou outros. Mas por agora, que o seu amigo o escute recitando versos a favor de Lípsio. ${ }^{53}$

Bem gostaria eu que o belga meu amigo

Teus hendecassílabos tivesse à mão!

Com que rosto os leria! Meus Deus, quantos abraços

Lhes daria, quantos beijos! Seriam mais

Do que os evocados por Catulo.

Mas, maldição! Aloja-se ele noutro mundo

Separado, bem longe. Portanto, agora, em vez do amigo fiel

Cobrirei de beijos estes números

Sem qualquer número. Meus amores

Direi, e ternura: e enquanto o caminho se vos fecha

Guardar-vos-ei alegre em meu alegre coração.

E agora a ti, Luís, brilho das Irmãs

Que velam superiores no meio do firmamento

Em nome da vontade de Justo Lípsio

Chamo-te a ti, a teus companheiros e amigos:

Concluo uma aliança perene de amizade.

Eis que Lípsio estende com prazer a sua dextra;

Vós as vossas estendeis, julgo que com prazer.

Ó coisa bem feita! Oh! Coisa maravilhosa!

Pessoas muito eruditas que estais vivas

Vistes coro mais erudito?

$$
\text { oOo }
$$

\section{Conclusão:}

Embora ainda faltassem mais duas cartas deste núcleo de correspondência entre Manuel Correia e Luís da Cruz, vou concluir. Tentei, com a apresentação desta desconhecida Centuria Secunda do epistolário de Manuel Correia, quebrar

${ }^{52}$ Carta 60 da Centuria Secunda de Manuel Correia.

${ }^{53}$ Os versos seguintes são propositadamente uma imitação de Catulo, perfeitamente reconhecível pelas alusões aos carmina 3 e 5 . 
um pouco a impressão de monotonia que, penso, se poderá ter do aspecto do humanismo português no dealbar do séc. XVII. Afinal, esquadrinhando melhor o aspecto desse humanismo, com a ajuda destas, quase todas, ignoradas cartas, vemos mais caminhos do que os que conduziam daqui apenas para Roma e para o Colégio Romano. Havia igualmente os que conduziam à Flandres, donde alguns esperavam avidamente que chegassem os frutos desse expoente de humanismo erudito que foi Justo Lípsio. Neste debate de ideias e partilhas de experiências literárias não se movimentavam apenas clérigos, fossem eles Jesuítas ou não, mas igualmente leigos, varões nobres, detentores de altos cargos políticos. E neste tempo de feroz inquisição, ainda havia quem ousasse, parece, chamar a debate nestas trocas de correspondência, a figura de Buchanan, o príncipe dos poetas, mas herético.

oOo 


\section{Apêndice}

\section{Epistularum Centuria secunda}

(BL, sloane 902)

\section{Correspondência entre Manuel Correia e Luís da Cruz}

[carta 19: Ibid. fls. 12r-13r]

Ludouico Crucio in Societate Iesu sacrarum literarum doctori S. D. 19

Quod ad litteras tuas eruditissimas insuper et amicissimas hactenus non responderim, non fecit Cruci Doctissime aut negligentia, aut tui obliuio, sed subita quaedam et repentina oculorum caligatio. Quod malum quam sit crudele, quam metuendum, nouit optime qui patitur: ego sane in summo sum squallore, in summa animi acerbitate, et metu. Vt autem infelicis casus ortum teneas, et humanae condicionis instabilem sortem, pauca haec perlege. III Non[is] Septembris, quo die celeberrimus ille fidei nostrae actus agebatur, amicorum aliquot rogatu inquisitionis atrium primo mane adii uisurus pertinacis et obstinatae mentis homines illos. Vt exeuntes uidi perfidiae amictos insignibus, quosdamque agnoui, quos antea deambulantes conspexeram sericis indutos, equis, mulisque uehentes, domum redii diram gentis barbariem admiratus, et ceruicem durissimam. Domi igitur $/ 12 \mathrm{v} /$ actus beneficio mihi uni uacans (molestos namque spectaculum abduxerat) et solitudinis captus dulcedine ad consuetum pabulum procurri, libros aperui, aptaui calamum, atramentarium composui, cogitationem denique hac occasione audaciorem multo feci, et liberiorem. Vtque rem omnem penitus intelligas (Martiali enim plenos adstruo commentarios) illa die sexaginta epigrammatis plenam apposui manum. Hoc duro penso cum defessos oculos animi gratia in uaria coniicerem, caligare eos sensi, et obnubi. Quo factum est, ut quam laetitiam legendo perceperam, et scribendo, parum uidendo tristissimus exuerem, in magnamque aegritudinem, ac maerorem conuerterem. Ad Deum primum excors accurri, amicos accersiui, medicos et chyrurgos consului, ut si possem tanti mali principiis saltem obsistere. Multi multa monent, ego pauca, uel nulla potius operor, ne forte quod mille aliis, mihi etiam curatione contingat uitalis lucis extinctio. Quocirca exteriores opes negligo, interiores dumtaxat, ut tutiores amplector: nimiis namque capitis humoribus malum istud et conflari, et augeri compertissimum habent quotquot de eo medice loquuntur. Quos quidem ego, etsi /13r/ rei medicae parum peritus, in incude tamen positus, et meo magno periculo sapiens, ausim asserere, ex assidua lectione, et scriptione profluere; nulla enim re magis aluntur, nulla magis fouentur. Medicis igitur potionibus res agitur, et catapotiis, et aliis quamplurimis, quae commemorare 
et tibi taedio et mihi sit dolori maximo, sola enim mentione distorqueor. Haec causa fuit, Cruci doctissime, intermissionis litterarum. Quis enim otio indulgeat in tanto negotio? Quis animi res agat in tanta animi perturbatione? Illud igitur te oro obsecroque: ut qui in Iesu Societate degis, socios tuos adeas, roges, cogasque Deum deprecari pro amico qui quamuis in amicitiae foedere non adeo est uetus, nulli tamen ueterum in fide et amore concedat. De epistula tua hoc unum: non tanti facit India lapillos, quanti ego epistulam tuam; quod si plures dederis, pluris faciam, tum quod plures, tum quod plus mihi dabunt et uoluptatis, et honoris. Vale. Olisipone XIX Kalend. Nouemb 1600.

[carta 39: Ibid. fls. 25r-26r]

Ludouico Crucio e Societate Iesu S. D. 39

Quo tu animo nostram legisti epistulam, eodem prorsus ego et tuam, beneuolo scilicet, et amico. Quid enim epistula tua in uerbis suauius, quid in consiliis utilius? Itaque eam libentissime perlegi, ac felicem sortem mihi primo gratulatus, multa deinde bona precatus sum Alvaro Lupo, uiro doctissimo, et amantissimo mei, cum talem mihi amicum conciliarit, qui et uirtute excellat, et doctrina. Atqui semper laetitiae comes dolor subsequitur; utque ille alter ait: 125v/ Toiouto o bios anthropou, euphainometha ellaton e lupoumetha: talis uita est hominis, laetamur minus quam dolemus. ${ }^{54}$ Quae enim epistula me in principio uera imbuerat laetitia, non multis post uersibus maerore accumulauit, dum tuam commemorat ualetudinem. Hac ego lecta ita dolui, ut oculorum dudum me conflictans dolor (solet hoc acerbiorum aduentu contingere) e mente nobis protinus abierit tuo plane concedens ut grauiori, ut acrius pungenti. Aegrotas, Cruci doctissime, malum quidem, malum magnum: sed corpore tamen aegrotas, non animo, non optima illa parte, quae ad animum ducit. Vides, uides: bonos illos affaris amicos, qui nobis numquam maerorem, uoluptatem afferunt semper. Et nos festino gradu ad caecitatem properamus carituri et amicis, et caelesti illa aura, qua fruimur, qua uiuimus. Didymus, ais, Alexandrinus caecus fuit, magni uir nominis, multae et politissimae literaturae. Hanc ego mihi uellem, caecitatem sibi capiat, qui uoluerit. At nunc mihi, si quando, oculi erant opus; habebam namque in incude magna fortasse (scies aliquando) ac feriatis aliquot horis Martialem addebam amicorum rogatu, qua tamen parte laudabilem, qua imitandum. Enitebarque ut publicaretur eruditissimus uates, omni purgatus ueneno, omni exutus crimine: iamque iampridem suadente Lupo nostro, nec /26r/ reluctantibus nobis, nuncque auctoritate tua omnibus uelis annuentibus. Damnamus Martialem impudicitiae, laudamus tersae latinitatis, et qui suo genere concedat paucis. Nosti uatem, tu eum Coryphaeum appelas. Nec mireris, si sexaginta mihi epigramata una dicam die elaborata; sexagies

\footnotetext{
${ }^{54}$ Talis uita...dolemus] na margem.
} 
elaborabo sexaginta. Nihil mutuum petimus, domi sunt omnia: calx, lapides, operae et operarum Magister, qui nouit optime architectari. De his tamen alias. Nunc Iusti Lipsii epistulas, alteram ad me, ad Nunum Mendozium alteram, discipulum olim nostrum, nunc Brusselae cum Alberto Principe commorantem, tibi mitto legendas; ut quid tibi uideatur Belga ille, respondeas. En nunc ad rescribendum materiam. Alias suggeret tempus. Quod si aliqua contigerit tuae uoluntatis, tui obsequii, haec mihi multo gratior, multo felicior existimabitur. Olisip Nonis Ianuariis 1601.

[carta 40: Ibid. fls.26r-28r]

Ludouicus Crucius Emmanueli Correae S. D. 40

Cum tuae litterae, mi Emmanuel, Conimbricam peruenerunt, lectulo affixus aegritudine iacebam. Quae ea sit, quam molesta, et diuturna, de Lupo nostro aliquando fortasse audiuisti. Cum uero traditae fuerunt, et intellexi esse tuas, respiraui. Leuamentum /26v/ aliquod contra dolores ab optimo amico (eum te quidem profiteor) allatum opinabar. Sed cum coepi legere, et intellexi quid calamitatis paterere ingemui. Quid ergo respondebo? Angorem mihi denuo peperere illae tuae litterae; in quo hoc boni, quod dolendo tibi, mihique satisfeci. Et ne apud te eadem sit uicissitudo, de me aegroto nihil. Vbi primum potui, ad scribendum preparaui. Accipe quales, quales istae tuae esse potuerunt. Age tua aegritudo non sit sine expectatione rerum meliorum. Valebis quam citissime. Et forte ea caligo ab oculis iam abscessit. Amplificabas id malum, credo, cuiusmodi sane fuit. Literatis, qui legendo, commentandoque pascuntur, non modo ea est grauis aegrotatio, sed animi acerba aegrimonia. Ceterum quo pacto sit sustinenda, non ignoras. Et tibi non erat gratia leuandi mali ad eos confugiendum, qui narrantur in fabulis fortasse data opera caecitatem asciuisse. Habebas exempla nostrorum, Didymi scilicet Alexandrini, qui quamquam oculis careret, non propterea infelicem se rebatur. Et doctrina ac sanctitate ita pollebat, ut Hieronymus non dubitaret Alexandriam nauigare, ut caecum adiret; atque ipsum aliqua percontaretur, quae sciebat mentis lumine abundare, ad ea illustranda, quae perspicax ingenio Hieronymus non uidebat. /27r/ Commemorabas eum locum, qui est amplissimus ad dicendum de instabili sorte rerum humanarum. Sic est. Ad hanc tragoediam nobilitandam omnes ita nati sumus, ut non modo iubeamur spectatores esse, sed etiam actores. Quot Oedipos in hanc orchestram quotidie det ista condicio, uides, mi Emmanuel, in quorum numero si te sors collocauit, non erit meum postulare ut lamentatione et in luctu te Roscium ostendas memorabilem; sed illum Didymum, cuius ante coepi meminisse. Redieras ab spectaculo illorum, quorum merito caecitatem detestabare. Tuam caligationem gratare tibi leuiorem, quae non eripuit mentem, qua te ualere scio, sed paulum a Martiali explicando retardauit. Et tu lucem dare illi homini putabas? Para. Agitantem ista non retardabo. Incidit ille 
in eum, ut spero, qui improbitatem, luxuriamque coercendo falce castissimae pudicitiae, quicquid in eo est acuti et eruditi dabit adolescentiae. Quaeque sit tractanda modeste, alios tua doctrina, tua uirtus, tua experientia diuturna, tua dignitas et sanctitas sacerdotii canique docuerint. Et fortasse docuisti tuo casu caecis oculis illum epigrammaton coryphaeum esse perlegendum, quem qui apertis tractarint, haurient, opinor, impudicitiae uenenum. Blandiri nescio, optime Emmanuel, serio cum amicis disserere candidi ingenii esse nosti. Sic te $/ 27 \mathrm{v} /$ opto bonas horas apud istum collocare, ut ex tuo colloquio prodeat non nequissimus, et tandem aliquanto prudentior loquatur seque ad eum diuertisse uideat, a quo didicerit morum fauere probitati. Sed sexaginta uno die epigrammata? Tam ardens es et uehemens! Legendo illa tamen fatigassent; quid quaeso commentando? Intemperiem istam me sine accusare. Pertulisses qui auiditate deuorando totidem patinas liguriret? Et non uides hanc esse in studiis auiditatem? Quid si inde, ut tu ipse non diffiteris, ista caligatio obrepsit? In posterum quid Emmanuel? Incolumitate restituta abibit metus aegritudinis? In altera sexaginta te armabis, ut una die dicare tot Antaeos Hercules in terram deiecisse, quot epigrammata confeceris interpretando? Mandabis obliuioni illud, quod est apud optimum poetam: maturate fugam? ${ }^{55}$ Fuga habet celeritatem, sed quam eam coerceat illud mature imperatum agnoscis. Quod igitur inde notum speude bradews tibi dictum puta. De medicis, quos allegabas, quid attinet disputare? De singulis si quis diceret:

quod si non aliqua nocuisset, mortuus esset, ${ }^{56}$

inuidiose loqueretur. Atqui a medicina speramus. Aegris ex ea disciplina promittitur ualetudo. Ambiguam uocem uides, et apud tuum Martialem est: centum tetigere manus - non habui febrim, Posthume, nunc habeo. ${ }^{57}$

Quid agendum? Accersendi sunt, et consulendi. Illi potiones inculcabunt, aurum para. Quantum boni ferent? Recte si non peperint nosemata. Illud est unicum perfugium, quod apud tuos est in extrema cura: deprecandum /28r/ Deum, Diuosque caelites, quos spero tibi bene facturum. Nosti hoc loquendi genus. Hanc aram imam, praesidio, salutique futurum satisfeci respondendo. Sit istud corollarium officii erga te. Nunc utcumque ualeo ad illa tua quae honestissimis nominibus appellas uoluptatem et honorem fauente Deo ualiturus. Si quid ego adiuto curamue leuasso scribendo, cur non faciam? Scribam, materiam praebe, prouoca, exilientem spectabis, nec ut exeam in hanc aciem cunctatior, ingenium detinebit Fabianum. Quod arbitrere hunc Lipsium ad tuum honorem pertinere, tribuo uirtuti tuae. Sed si est inde aliquid ornamenti, quantum ex me erit euadet meus Emmanuel Correa ornatissimus.

\footnotetext{
${ }^{55}$ Virg., Ae. I, 141.

${ }^{56}$ Cf. Virg. B. III, 15

${ }^{57}$ Cf. Mart. V, 9
} 
Appellas te amicissimum, amplector, dabo operam, ne queri possis aliquando te deceptum; et uideo quantum in meam fidem recipio. Parem exibere animum tuo, non arbitror esse leue. Conimbricae XIII Decemb[ris] 1600. Haec aegra manu scripta boni consule.

[carta 59: Ibid. fls. 38v-40v]

Ludouicus Crucius e Societate Iesu Emmanueli Correae S. D. 59

Beneuolentia et communio quaedam studiorum, mi Emmanuel, effecerunt, ut peramanter nostra legeres, quod etiam in tua epistula perlegenda me praestitisse /39r/ confiteor. Legi saepius legamque libenter, quoties uacauerit, et putaris amicum, quem esse uoluisti recreandum. Aegritudinem qua me scripsi detineri, non ideo commemoraui, quod eam dolori esse uoluissem, sed ut tuam quoquo modo leuarem calamitatem; ne tu te unum salute afflicta existimares, propterea ab scribendo et commentando cessaturum. Nam nos etsi cruciamur, animum tamen erigimus, et parte superiori contendente damus operam ne doloribus oppressi succumbamus. Quod si Didymus non placet, quem ad minuendum id malum, quo nuper laborabas, afferebam? Mihi, tibique Gregorius in mentem ueniat, cui non obstitit iniquissima ualetudo quominus agendo et scribendo Magni cognomen unus assequeretur. Quam ob rem uale ac graecus ille tuus. Deiecti animi eam sententiam ambo arbitremur. Etsi multa uitam incommoda circumueniant mens accuratiori studio Christianae sapientiae ea mitigare lenireque contendat. Quare id precor, optime ornatissimeque Correa, ut si quando aegritudinem doloresque retulero, ne ad maestitudinem scriptos interpretere, sed ut roges eum, qui omnia moderatur aequabilitatem ut praestet adferendum, et illam unicam uirtutem bonis omnibus plausibilem concedat, nempe tolerantiam. Tibi oculos amo, restitui exopto, acerrimosque redire quales fortasse adolescens habuisti aut, quoniam Dydimus esse recusas, uidendo lyncas superes, ut ingenii tui, studiorumque laudem aspiciat posteritas, et fructum industria, solertiaque adipiscare. Haec si nostro Lupo communicaris, me hortatore ipse augeat: et quoniam te alloqui potest quam saepissime, inci/39v/tet ad illius operis molitionem. Ne tu igitur, ut uereris, ad caecitatem festinato. Sperandum meliora, praesertim cum conatus tuos intelligamus eo pergere, ut habeant homines Lusitani Lusitanum, qui ueteres auctores explicando efficiet, ut necesse sit ad alienas prouincias commigrare: ut inde sint, qui Martialem lepidum illum quidem, sed obscurum explanent. Habes ruta caesa, ${ }^{58}$ et architectum, animum etiam optimum et uoluntatem, amicorum uota, iudiciaque nosti. Architectare, pergeque ut quam citissime te legamus. At ne qua iterum te suspicio quatefaciat, si nihil de ualetudine recenseam, sic habeto: ualeo, mi Emmanuel, quotidie habeo scholas, interpretorque

\footnotetext{
${ }^{58} \mathrm{cf}$. Festus 262.
} 
Danielem, et frequentior contionor, quam fortasse putant nostri, qui sunt in Collegio Antoniano. Ea uero causa fuit quod serius tuis literis responderem. Abierunt illi dies propter Christi Seruatoris natalitia feriati; quo primo licuit pergere in theologicum Lyceum, ad ianuam inueni qui tuas dedit. Rescripsisti celerrime, ut mihi, tibique satisfacerem: sed ternae per hosce dies habendae contiones /40r/ spatium dedere nullum, inuitum retardarunt. Quid amplius Emmanuel? Venio ad Lipsium. Epistulam quoque legi, recreauit, quod ad te uir doctissimus scripserit. Ad illum uiam esse, gratum mihi, et uolupe: et quod ille de Lusitania recte, id etiam uoluptati. Accusat bella, suscepisset ad nos profectionem, si arma quieuissent. Tranquillari illam prouinciam quis non optet, quae homines gignit illius modi? Ceterum, si ad eum scribis, dehortare ne, etiam si possit, huc pergat nauigare. Inueniet Lusitaniam, urbemque tuam non florentem, ut solebat, sed obsitam et pestilentiae malo frustratam. Malo eum apud Belgas dolere audiendo, quam in nostra calamitate maerere contuendo. Lipsium legimus, admiramur uiri diligentiam, ac doctrinam. Panegyrica ad nos non peruenere. Sed quoniam quid de eo sentiam requiris, in hac extrema cera hendecassyllaba demonstrabunt. Age, scribe, uale. Ede Martialem. A te doctissimum, et pudentissimum opus est abiturum. XVIII Kal./40v/ Ianuarii 1601.

Emmanueli Correae de Iusto Lipsio

Cum nuper Crucium tuum rogasses

Quam laudem dare Lipsio soleret

Respondit sibi Lipsium uideri

Cretaeum folio medente gramen

Natum reddere sauciis salutem.

Antiqui in triuiis uiri iacebant

Quorum uulnera nemo non dolebat.

At qui Paeonia manu chirurgi

Tractarunt, ope profuere nulla.

Dictamni ${ }^{59}$ tamen huius ut saporem

Et succum uetus aegritudo sensit

Sic fugit, bona Sospitas, ut esset

Illis, qui senio fugacis aeui

Tamquam deposito fores tenebant.

Iusto quid dabo laudis ? O ab Ida

Dictaea rosa lecta, uiue, tactu

In uitam exanimes tuo redibunt.

\footnotetext{
${ }^{59}$ Correxi ex Dictami
} 
[carta 60: Ibid. fls. 40v-42r]

Ludouico Crucio S. D. 60

Nae ego felix homo sum, felici illa dico /41r/ animorum parte qua amamus. Cui enim umquam tale contigit amicorum sodalicium, talis amor? Hinc Lipsius literarum pelagus, illinc Crucius a Musis factus, inde sexcenti adsunt alii, suo quisque modo, praecellentes. Hos ego mihi amicos malo quam aurum, quam fortunae gradum altissimum. Perit aurum, perit gradus ille. Soli amici manent, aeternumque manent, nullo interituri casu, nullo infortunio. Hinc ego librorum meorum horulam non mutauerim uel diuturno imperii sceptro, uel thiara Pontificia. His namque sua sunt taedia, sua scabra: ${ }^{60}$ Libris nostris summa semper uoluptas, summa gaudia; qualia mihi maxima tua haec ultima attulit epistula. Recreauit me, ita uideam, et ad maiora animauit, quam uires ipsae, quam animus ualeat. Sed hortaris tu, Cruci doctissime, imperas potius: accurrendum igitur ad falcem et demetendum sine metu. Quid plura? En Martialem in fornacem mitto, fundetur quanto ocius, exibitque quam fieri possit, prudentior, et pudentior, et ad amicorum gustum. Addam etiam alium, uel alios, non deterioris saporis, fellis tamen alicuius. Illud /41v/ quidem uehementer doleo, in saeculo adeo caenoso uiros uixisse, quos amo ob tersam latinitatem. $\mathrm{Ob}$ id illis aliquid condonandum, immo seculo. Quare adhibendi rastri, expurgandique, et e medio illo caeno extrahendae margaritae pretiosissimae. Haec tamen tempus, ut omnia. At te imperante quam citissime, et citius multo quam institueram. Nunc uale, ac Corream tuum pro Lipsio canentem audi, dum Lipsio non licet:

Quam uellem, meus ille Belga doctos

Tuos hendecassyllabos haberet!

Quo uultu legeret! Deus, quot illis

Amplexus premeret ! quot oscula! essent

Plura, quam memorant Catulliana.

Sed nefas, alio est locatus orbe

Longe seposito. Ergo nunc amico

Pro fido hos numeros deosculabor

Absque ullo numero. Meos amores

Dicam, et blanditias: sinumque laeto,

Dum negatur iter, tenebo laetus.

At nunc te, Ludoice, lux sororum

Quae celsae medium tuentur orbem,

Iusti nomine Lipsii uolentis

\footnotetext{
${ }^{60}$ Correxi ex. scabris
} 
Apello, ac socios, tuosque amicos, Foedus percutio perenne amoris. /42r/

Dextram Lipsius en libenter offert

Vos uestras dabitis, puto libenter.

O factum bene! o suaue factum! ${ }^{61}$

Quotquot uiuitis eruditiorum,

Vidistisne chorum eruditiorem?

[carta 75: Ibid. Als. 52r-53v]

Ludouicus Crucius Emmanueli Correae S. D. 75

Doluissem equidem, mi Emmanuel, si suspicari possem, moram harum litterarum molestiae aliquid tibi expectanti peperisse. Eras in expectatione fortasse, idque amici facere solemus. Cunctatior ego respondeo, idque uidebitur, amori nostro, et uirtuti tuae offecisse. At si te noui, diuinasti, opinor, non respondentem impediri eo malo, quo solo potuit impediri. Aegritudo fuit in causa, quae hoc Martio ita manus, digitosque occupauit, ut usum nullum reliquum fecerit laboranti. Nunc paululum recreatus calamum accipio, idque ex Lupo nostro forte discere potuisti. Cui cum deberem, non illi prius, quam tibi satisfacio. Quid ais, uir doctissime? Tuarum exordium exhilarauit. Felicem tu te praedicas; quod id, quod in humana uita longe praestantissimum habetur, sortitus sis. Ego ista felicitate tua te macte esse iubeo. Habes amicorum chorum, in quo Lipsius restim ducit, et sexcentos praecellentes, ut appellas, et me ei pulcherrimae choreae $/ 52 \mathrm{v} /$ participem esse uoluisti, eo tamen titulo ornatum, quem tribuis nimis liberaliter. Crucium a Musis factum ais; si fecissent, elegantiorem, mihi crede, tornauissent. Praerogatiua modestiore apud te in isto honestissimo sodalicio tuo esse uolo. Sed hoc tempore cur hoc gaudio non triumphem, cum repertum uideam uirum eruditum, tantum libris, et eruditioni tribuentem, ut ista auro, et Pontificum thiaris anteponat? Felix qui isto animo es. Facito, ut pecuniae exponantur in foro, istique honores cum libris, et eruditione permutandi ab Cominbrica celerrime conuolabunt; qui quae studendo docendoque compararunt, illi largientur, qui aurum, qui sacerdotia dederit opulenta, existimantes cum opibus et honore nihil nec optimas quidem disciplinas praeparari posse. Ad has nundinas non uenisse te optima rerum pretia intelligentem gratulor et uirtuti et felicitati tuae. Quod amicis aeternitatem promittis, id est, ut interpretor, constantiam, id quoque te unum inuenisse, magnae mi uoluptati esse debet. Quam enim sint huius aeui infidae amicitiae ignorare non potes. Tuas esse firmas, quis non admirando gratuletur? Philosopharis interdum, scabiem et taedia in principum esse dominatu commemoras. Ita est. Tu ex tuo Musaeo capis uoluptatem; eam

\footnotetext{
${ }^{61} \mathrm{O}$ factum... factum] $\mathrm{O}$ foedus superum, o suaue foedus ras..
} 
/53r/ aliunde uenari nec soles, nec necesse est. Quid? Paratam habes in omnes horas hilaritudinem, quae apud ordines honoratorum esse non solet. Fruere isto bono, quod opto tibi quam maxime diuturnum, modo in publicum redundet emolumentum. Et redundabit spero, cum nos spe tuorum operum impleueris. Prodeat tuus ille Martialis me etiam hortatore; et uideat Lusitania aliquem, quem Belgis illis, Batauisque opponat. Intelligantque illi, non solos esse se, qui bonas litteras retineant. Etiam Emmanuel Correa ostendet eas apud Olisiponem habere domicilium. Addes, quod illi fortasse non fecissent; pudentiorem exire iubebis illum ipsum Martialem, ut sine offensione legant omnes, ipsaque iuuentus addiscat elegantiam sine molestiae, pudorisque iactura. Corollarium etiam polliceris? Istuc est in communem sine fraude utilitatem laborare. Sed de felle non intelligo. Si sordes id signant, non metuo. Inciderunt illi, quiqui sunt in censorem, qui sordidissimum cum multauerint, ceteros etiam persona uestiat modestiore. At si fel acerbitatem prae se fert, sine. Scitum est illud tui Martialis

Infanti melimela dato, fatuasque mariscas:

Nam mibi quae nouit pungere, Chia placet. ${ }^{62}$

Ad extremum, quid sentiam de tuis hende /53v/cassyllabis reseruaui; lepidos, uenustos, aio, et Catullianos. Ita quoque Emmanuel? Ostendi lectissimis magistris, qui docent hic Conimbricae. Non dubitaui dicturos quae protulerunt. Hoc solum, et te Phoebus amat. Copiosior fuissem, si sineret imbecillitas. Sed uides, impolite scribis, manus mea. Et uinco, uicique animi uoluntate facultatem. Vale Conimbricae VII idus Aprilis 1601.

[carta 78: Ibid. fls. 57v-59r]

Ludouico Crucio S. D. 78

Et ego etiam ad scribendum tardus. Vt tua te chiragra, ita mea me caecitas remoratur. Auertat Deus mala haec, et nos nobis reddat, ut uiuamus securius, et scribamus diligentius; neue crebro pendeamus crebris suspicionibus, et metu qualis mihi maximus erat, cum tua accessit epistula, solitis tuis leporibus cumulata, et prospera ualetudine. Vera loquor, haec tua epistula summa me laetitia perfudit. Sensit domus mea, senserunt uicini, et amici, quotquot mihi in hac urbe, qui quidem plurimi sunt. Non tamen sensit Aluarus ille Lupus, meae pars maxima animae, immo mea tota anima. Aberat, Cruci doctissime, aberat; iam biduum in Portum discesserat Societatis uestrae iussu; sed sentiet quantocius, non enim illum hoc tantum gaudium celabo. Sed de illo prae /58r/ lacrimis non plura; de nobis igitur aliquid. Propensum illud meum in libros studium, quod ego felicitati tribuo proprium temporis infelicitatem tu ipse probas etiam; nescio tamen an serio uel ioco; ego serio quidem accipio. Nihil.

\footnotetext{
${ }^{62}$ Cf. Mart. VII, 25, 7-8
} 
Enim mihi magis serium, quam amicorum sodalicium, in quo potissimum libros constituo. Hunc tu locum amplificas in epistula, et philosophationem appellas, et bene; nam et nos iam aliquando huic studio horas aliquot impendimus, et nunc libentius, cum nostrates omnes occupatos uideamus in meris nugis, in meris potius furtis, caedibus, iniustitiis. Vtinamque esset pecunia, quae ad tuas illas deferretur nundinas, in tuam illam, quam commemoras, commutationem. At nunc fama est, regio edicto regni argentum omne congregari ad pecuniam cudendam; cuius tantam aiunt, futuram copiam, ut uel per uicos confluat aquae instar. Haec nunc de iis tantum. Quaeris de corollario nostro, et felle. Corollarium nostrum Catullus noster erit, et quidam alii in quibus etiam suum est fel, id est, saeculi sui amaritudo quaedam. Curabimus tamen, ut minus amarum sapiant. Quod hendecassillabos nostros lectissimi legerint uiri, laetor maxime, et tantorum uirorum iudicio multo magis; illud sciens certissime, quicquid $/ 58 \mathrm{v} /$ mihi iamdudum laudis accrescit, ex uberrimo bonae tuae indolis, et eruditionis fonte accrescere. Vale ac nos contra ama.

Olisipone VI Id. Ma. 1601

Complicata iam epistula, in monstrosa hac urbe monstrum hoc accidit: mulier quaedam triennium totum, et eo amplius, totam hanc urbem et equo et pede perambulabat, homo nomine et ornatu. Nomen illi, Emmanuel Sousa Coutinius, ornatus militaris, sericus tamen, et elegantissimus. Monasteria frequentabat, publica etiam adibat gymnasia, et colloquia publica, a primario quodam ductata uiro, uel potius, uiris, quos honestatis causa praetereo, et pudoris. Alia etiam faciebat nefanda, aiunt, facta quae referre pudet, dilatabunt alii. Cum autem diaboli soleae tandem rumpantur, et hae etiam ruptae sunt. Quid plura? A Doctore Gregorio d'Oliveira criminalium rerum iudice uiro et iudicio et manu suspiciendo dolo bino captus est formosulus iste adolescentulus, et delicatulus. Stricte in carcere custoditur, donec factum iudicetur strictissime. De ultimo rei euentu, ubi certum quid constiterit, certo adscri/59r/bam. Quid, quod et haec et similia neque scriptione indigent, neque admonitione. Fama uolat. Vale iterum et solue. 


\section{Aires Barbosa, Professor, Pedagogo, Filólogo e Poeta ${ }^{\mathrm{I}}$}

Sebastião Tavares de Pinho

Universidade de Coimbra

Se há escritor novilatino, dentro do panorama geral do humanismo literário renascentista português, que tenha deixado na sua produção escrita um signo eminentemente didático e pedagógico, é, talvez como ninguém, o aveirense Aires Barbosa, que repartiu a sua vida pelo último quartel do século $\mathrm{XV}$ e a primeira metade do séc. XVI e que é, sem dúvida, o primeiro dos grandes humanistas portugueses.

Mas quem era Aires Barbosa, de seu nome completo Aires Figueiredo Barbosa?

Ao contrário de muitas outras figuras de topo da cultura lusíada que não cuidaram de informar os seus eventuais futuros leitores acerca das suas próprias origens, provocando, não raro, com isso muito derramar de tinta e acirrados ciúmes de rivalidade bairrista, Aires Barbosa deixou esse problema resolvido, libertando-nos a todos dessas porventura ociosas curiosidades, conforme ele avança quando escreve com certa ironia, à cabeça do seu tratado de Prosódia, o seguinte epigrama:

\section{De Patria Sva et ParentibVs}

Scire uolet patriamque nomenque parentum,

Has quisquis nugas gaudet habere meas.

Nec diues multum, nec paupertate notandus,

A notis quondam sed tamen ortus auis,

Fernandus Barbosa pater, Catharinaque mater,

A notis etiam, quae Figuereta, uenit,

Me genuere, furit uastis qua fluctibus ingens

Vltimus occidui litoris Oceanus.

Quaque habet Aueiro portu praediues amoeno,

Quicquid habet tellus et mare quicquid habet.

Non procul auriferi nostram hanc Duriique Tagique

Hinc illinc mediam ripa beata tenet.

(vd. Prosodia ... Orthographia, Epigr. [34])

\footnotetext{
${ }^{1}$ Publicado, na sua primeira forma, nas Actas do I Congresso Internacional "Humanismo Novilatino e Pedagogia (Gramáticas, Criaçôes Maiores e Teatro)", Braga, Universidade Católica Portuguesa, 1999, pp. 131-148, e em Humanismo em Portugal. Estudos I, Lisboa, INCM, 2006, pp. 97-114; e agora revisto, atualizado e corrigido em função de novos dados entretanto conhecidos.
} 
Acerca da sua terra natal e de seus pais

Quem quer que tenha gosto em conhecer estas minhas bagatelas há de querer saber da minha terra natal e do nome de meus pais.

Deram-me a vida meu pai Fernando Barbosa, nem muito rico nem infamado de pobreza, mas oriundo

de famosos antepassados; e minha mãe Catarina Figueiredo, também ela proveniente de uma renomada família.

Deles nasci, lá por onde, em gigantescas ondas, se enfurece o extremo Oceano da praia ocidental, e por onde Aveiro, opulento pelo seu porto ameno, tudo retém quanto a terra tem e tudo quanto o mar contém.

Não longe, de um lado a fértil riba do Douro, do outro a do Tejo, de auríferas águas, delimitam esta nossa que no meio fica.

Nascido por volta de 1475, propriamente em Esgueira, hoje simples freguesia anexa à cidade de Aveiro mas nessa época uma notável vila que chegou a sede de comarca ainda no tempo de Barbosa, ${ }^{2}$ foi aqui que ele viveu e teve a sua primeira formação humanística até à volta dos 14 anos.

Depois frequentou a Universidade de Florença, onde conquistou o título de mestre de Artes e onde teve o privilégio de contar com mestres consagrados, como Ângelo Policiano, e com famosos condiscípulos como o futuro papa Leão X, da família dos Medici, conforme, anos mais tarde, ele mesmo recorda num dos epigramas de defesa frente aos seus adversários filobárbaros do meio universitário salmantino.

Regressado da Itália com cerca de vinte anos de idade e uma sólida formação académica, logo passou, a convite da Universidade de Salamanca, a fazer parte do corpo docente desta Escola e aí exerceu, a partir de 1495, um magistério que havia de perdurar por vinte e oito anos, dedicado ao ensino da língua latina e da grega (cujo estudo Barbosa inaugurou em toda a Península Ibérica), e na função de titular da cadeira de Retórica. Jubilado em 1523, regressa definitivamente a Portugal e, a instâncias de D. João III, assume, na corte portuguesa, o encargo de mestre dos irmãos do monarca até 1530, ano em que finalmente se recolhe à sua terra natal de Esgueira, para aqui passar os seus derradeiros 10 anos de vida. A sua morte ocorreu em 20 de janeiro de 1540.

\footnotetext{
${ }^{2}$ Esgueira foi elevada a sede de comarca por D. João III, em 20 de Dezembro de 1533, justamente quando Aires Barbosa aí passava o retiro de sua jubilação e aposentadoria definitiva. O âmbito geográfico e administrativo desta sede judicial, com 31 vilas, 10 concelhos e um couto, desde Ovar, Vila da Feira e Vale de Cambra ao norte, Sever do Vouga e Castanheira a nascente, e Vagos, Vilarinho do Bairro e Avelãs de Cima a sul, correspondia aproximadamente ao que é hoje o distrito de Aveiro.
} 
Em todo o tempo de professor, quer no ativo, quer jubilado, e mesmo no otium dos últimos anos, Aires Barbosa procurou sempre associar a sua qualidade de mestre profissional à de escritor-pedagogo. Durante o professorado salmantino publicou parte dos próprios cursos aí ministrados, a par com produções de caráter poético; e no tempo da jubilação compôs e editou, em 1536, o famoso poema Antimoria juntamente com uma coleção de 50 epigramas, fruto da inspiração das horas de lazer.

A sua primeira obra, saída em Salamanca em 13 de junho de 1511, ostenta um título que transcreve as palavras de um passo de Quintiliano, In verba $M$. Fabii. Quid? quod E' reliqua. Relectio de verbis obliquis, e que podemos traduzir desta maneira: Contra as Palavras de Marco Fábio Quid? quod etc. Releção ${ }^{3}$ acerca dos Verbos Oblíquos.

No proémio deste livro Barbosa recorda que, um dia em que comentava Horácio numa lição do curso de 1510-1511 e expunha as particularidades sintáticas dos verbos impessoais do tipo licet, piget e outros, se viu verdadeiramente assediado, no fim da aula, pelos estudantes que a ele recorrriam para as explicações e resolução de dúvidas, como era prática regulamentar em Salamanca. Desta vez o grupo era dos que não tinham ficado inteiramente convencidos das teorias do mestre e que, usando de um discurso lábil e um jeito tergiversante (uerbis lapsantibus et tergiuersanti ratione), punham em causa aquelas teorias. Este incidente foi motivo para que, no intuito pedagógico de clarificar este assunto e banir o erro da mente dos seus jovens alunos, Aires Barbosa redigisse e publicasse a referida "Releção acerca dos Verbos Olíquos".

Trata-se, pois, de um texto que expõe por escrito matéria dada no curso de 1510-1511 sobre a definição e consequente existência, ou não, de verbos impessoais, assunto polémico entre os gramáticos desde a Antiguidade. Barbosa começa por apresentar a argumentação dos que negam a sua existência, mencionando Quintiliano e o nome de outros gramáticos como Diomedes, o mauritano Prisciano de Cesareia e Apolónio, o Díscolo (“O Misantropo"); disserta sobre a noção de impessoalidade verbal, rejeita certas definições e propõe outras, insiste na distinção entre verbos pessoais e impessoais, entre verbos retos e verbos oblíquos, fala sobre o conceito de "pessoa" na linguagem teológica da trindade divina, no âmbito filosófico da pessoa humana, sobre a noção de pessoa física e de pessoa jurídica, para as distiguir da noção da pessoa gramatical, aplicada à designação de verbo pessoal e verbo impessoal. Termina dirigindo-se aos jovens da sua Universidade e oferecendo-lhes este estudo como exemplo e demonstração das suas vigílias e como simples amostragem do muito que tem pensado sobre esta matéria.

${ }^{3}$ Decidimos traduzir relectio por "releção" (em vez de "releitura") em conformidade com outras formas da mesma raiz consagradas em português, como "preleção". 
A Relectio de uerbis obliquis apresenta-se, pois, como um livro de intenção claramente didática e pedagógica, demonstrada não apenas ao longo do desenvolvimento de todo o seu conteúdo, como acabamos de ver, mas também de um modo particular a partir das suas primeiras páginas, que constituem uma espécie de exórdio de singular interesse, por explicar a razão de ser deste livro, por descrever todo o vasto programa didático da atividade que Aires Barbosa se propunha realizar nos próximos anos, e, enfim, por se apresentar como uma defesa do ensino da ciência gramatical entendida no amplo sentido de estudo da língua, da cultura e da literatura clássicas, como base e instrumento de todas as outras ciências.

Em 3 de julho de 1515 Barbosa publica a Relectio cui Titulus Epometria, um verdadeiro compêndio de métrica latina que, pela sua utilidade prática, pela notícia que nos transmite sobre o valor concedido pelos humanistas aos aspetos do ritmo e da musicalidade da língua e, ainda, pela sua raridade bibliográfica, se apresenta como uma verdadeira preciosidade. Trata-se, mais uma vez, de um trabalho didático, resultante de um curso ministrado em ano anterior, que apresenta muita da matéria ligada ao caráter quantitativo da locutio latina, cujas regras, para mais fácil memorização, aparecem enunciadas sob a forma de verso, e em que o Autor expõe aos seus queridos estudantes (auditores suauissimi) as razões da importância que tem o conhecimento desta ciência para a análise de uma obra poética.

Em abril do ano seguinte, em 1516, Aires Barbosa publica, a pedido insistente dos próprios alunos, mais uma obra de caráter sobretudo filológico: o longo e erudito comentário à História Apostólica do cardeal Arátor (Aratoris Cardinalis Historia Apostolica cum commentariis), poeta cristão dos sécs. V-VI que parafraseou em hexâmetros latinos os Atos dos Apóstolos. O comentário filológico de Aires Barbosa a este poema foi objeto de curso de 1513-1514 e representou de algum modo uma resposta prática aos velhos mestres salmantinos - sobretudo juristas e teólogos - que o acusavam de dedicar as suas aulas apenas a autores pagãos. Barbosa mostrou-lhes, com este curso, que as técnicas da filologia humanística se podem aplicar à análise literária de qualquer texto. Daqui resultou um grosso e compacto volume de amplo e variado trabalho filológico, que envolve o estudo de questões gramaticais, de história, de literatura, de arqueologia, de filosofia, e mesmo de jurisprudência e teologia, a ponto de os seus adversários, não contentes agora por ele se meter em seara sua, o atacarem de novo. Barbosa defende-se em epigramas que publica no final do volume.

Em dezembro de 1517, Aires Barbosa publica, de uma só vez, mais duas releções, uma sobre Prosodia, outra acerca de Orthographia, duas matérias de particular interesse para o estudo da pronúncia e da escrita das línguas clássicas: do Latim, naturalmente, mas também do Grego, na medida em que 
o Autor faz, não raro, a aproximação dos dois idiomas e, sobretudo, pelo facto de, por falta de tipografia grega, transcrever em carateres latinos as frequentes citações de textos gregos, denunciando assim a pronúncia da língua helénica naquela época.

Estes dois tratados didáticos constituem a última publicação em prosa de Aires Barbosa e, juntamente com os 36 epigramas que os acampanham, o fim da sua atividade editorial em Salamanca.

Mas se as relectiones de Aires Barbosa demonstram o caráter pedagógico e didático da sua produção em prosa, a mesma preocupação do humanista manifesta-se também em grande parte do resto da sua obra, isto é, em vasto número das mais de cem composições poéticas que ele deixou sob a forma de epigramas, quer dispersos, desde pelo menos 1495, por vários livros de amigos seus como António de Nebrija, Lúcio Marineo Sículo, Pedro Mártir de Anghiera, Pedro Margalho e Lourenço de Cáceres, quer sobretudo em duas coleções dadas à luz juntamente com outras obras. O primeiro destes conjuntos, em número de 36 poemas, saiu a lume, como dissemos, em Dezembro de 1517 no mesmo livro que inclui os tratados da Prosódia e da Ortografia. A segunda coleção, num total de 50 epigramas, surgiu dezanove anos mais tarde, em apêndice ao Antimoria - o seu poema de maior fôlego, escrito contra as ironias de Erasmo expostas no "Elogio da Loucura" (o Encomium Moriae) -, precisamente no ano da morte deste humanista flamengo, em 1536.

Este número considerável de composições poéticas oferece uma vasta gama de temas, uns de circunstância, outros que correspondem ao pensamento e preocupações dominantes do poeta.

Escolhemos para as considerações deste momento os cinquenta epigramas publicados com o poema Antimória, por eles reunirem a maior parte da melhor poesia do humanista escrita (em todos os casos ou pelo menos em grande número) e organizada em Aveiro. Ainda que seja impossível fazer uma classificação total e rigorosa de cada um, dada a natureza variada de muitos deles, podemos agrupá-los em quatro séries: composições laudatórias, poesias de reflexão pessoal e de autobiografia, versos de intervenção política e, sobretudo, epigramas satíricos.

Pertencem ao modo encomiástico e gratulatório os que exaltam as virtudes dos príncipes e protetores, a competência dos mestres e a qualidade dos literatos. Estão neste caso os Epigramas 1, 18 e 26, dedicados ao cardeal-infante D. Afonso, em que o Autor exalta o seu patrono e mecenas e lhe agradece a sua amizade demonstrada em horas de grande provação; o Epigrama 33, dedicado a D. Sancho de Castela, reitor da Universidade de Salamanca, e evocativo da viagem feita com ele à Itália, integrado na embaixada académica ao Papa 
Adriano VI; os Epigramas 9 e 30 dedicados respetivamente ao estro poético de Mestre Gonçalo e à elegância literária da célebre humanista coimbrã Joana Vaz.

Entre as pessoas envolvidas nestes elogios destaca-se a figura do cardealinfante D. Afonso, o mais velho de todos os irmãos de D. João III, dos quais fora mestre Aires Barbosa depois de jubilado pela Universidade de Salamanca, a partir de 1523 e até 1530 quando se recolheu definitivamente a Esgueira. Barbosa guardara variadas recordações desse tempo, em que exercera funções de mestre da corte, e do convívio com os infantes D. Afonso, D. Luís, D. Henrique e D. Duarte, assessorado pelo jovem humanista André de Resende. Mas o que mais o marcou foi a amizade do Cardeal-Infante, demonstrada em momentos difíceis por que passara o seu mestre, designadamente por ocasião de uma epidemia em que ele se sentiu doente e abandonado de todos, mesmo dos criados, mas não do seu antigo aluno purpurado. Aires Barbosa exprime a sua gratidão no seguinte epigrama com que abre e lhe dedica a referida coleção dos cinquenta epigramas de 1536 :

\section{AD D. ALFONSVM CARDINALEM INFANTEM}

Quae mibi misisti uenere in tempore dona, nummorum ferret cum mea byrsa nibil.

Tristis erat cum ad se uenientem cerneret ipsam confectam macie nostra Thalia famem.

Nec soluebat adhuc, arcam qui temperat Hector. Rebus in angustis spes mibi solus eras.

Nec spes uana fuit. Cumulasti munera, princeps inclite. Dona fere sunt duplicata mibi.

Expauit ieiuna fames centussis aceruos. "Hic, saturum fugiens, non habitamus, ait."

His alia adiungis. Famulis numeroque tuorum cognatum ascribis mancipiumque meum.

Singula quid refero? Sunt infinita. Sed illud aurea fert, princeps, nomen in astra tuum:

cum fureret metuenda lues in meque meosque, in nostris oris, heu!, metuenda magis.

Quilibet euitat diri contagia morbi, in se tabificum ne fluat inde malum.

Hinc miser, hinc hostis cunctis mortalibus, ut si maiestas esset regia laesa mibi.

Tecta negabantur, deerant alimenta repulso undique, fronde fuit sub Ioue tecta domus.

Tempore in hoc duro, quo tanquam publicus hostis in solas terras ipse iubebar agi, 
ausus es, oblitus trabeaeque rubrique galeri,

solari alloquiis muneribusque tuis;

desertum a cunctis miserabiliterque iacentem

tollere consilio, tollere meque manu;

me dominus famulum praesens constanter adire,

me, cum me famuli destituere mei.

Haec tua rara fides orbis celebrata fauore est, plus tamen huic plaudunt alta theatra poli.

Pro tantis, igitur, meritis et talibus et tot, dicere quas grates, quasue referre parem?

Succumbunt oneri uires, umerique recusant tantarum laudum pondera ferre mei.

\section{Ao Cardeal-Infante D. Afonso}

Em boa hora chegaram as dádivas que vós me mandastes, pois minha bolsa não trazia nem pinta de dinheiro. Ficava triste a nossa Talia quando via a própria fome a abeirar-se dela morrendo de magreza.

E Heitor, o tesoureiro-mor, há muito que não me pagava.

Nas horas de aperto, só vós éreis minha esperança.

E não foi esperança vã. Acumulastes as ofertas, ínclito Príncipe. Tive dádivas quase a dobrar.

A fome jejuna ficou apavorada com os montões de cem asses.

E, fugindo da fartura, diz: "Aqui não é nossa morada."

A estas, juntais outras mercês. Associais aos criados e ao número dos vossos um mancebo da minha família.

Para quê referi-las a todas? Elas não têm fim. Mas aquilo que eleva, meu Príncipe, o vosso nome até aos astros dourados é isto:

Quando contra mim e contra os meus se enfurecia a temível peste, ela era nas nossas regiões, oh!, mais para temer.

Toda a gente evitava os contágios da funesta doença, para que, daí, o mal deletério a si se não apegasse; miserável por um lado, inimigo para todos os mortais por outro, como se eu tivesse cometido algum crime de lesa-majestade régia, repeliam-me por toda a parte. Negavam-me abrigo, faltavam-me os alimentos, a casa era ao ar livre coberta de ramagem.

Neste tempo duro em que, como se eu fora um inimigo da Pátria, me mandavam levar para terras solitárias, ousastes, esquecido de vossa capa de púrpura e do chapéu vermelho, consolar-me com vossas palavras e vossas ofertas; quando eu estava abandonado de todos e jazia na miséria, ousastes aliviar-me com vosso conselho, aliviar-me com vossa mão, ousastes com frequência visitar-me como meu propício senhor, a mim, o vosso criado, quando meus criados me haviam abandonado. 
Esta vossa rara fidelidade é celebrada pela estima do orbe, porém mais aplausos lhe dá a nobre assembleia do Céu.

Por tamanhos, tais e tantos méritos,

Que graças, pois, poderei eu dar ou retribuir?

Sucumbem ao fardo as forças, os meus ombros

Recusam suportar o encargo de tamanhos louvores.

Enquadram-se na poesia de caráter pessoal e autobiográfico o epigrama 2, escrito no momento da despedida de Salamanca; o Epigrama 23, de meditação pessoal, em que o Autor, ao ver o seu corpo a definhar pelo sofrimento, prenunciador porventura da morte, se encoraja com a ideia da imortalidade da alma, em contraste com a caducidade do corpo, numa clara demonstração de influência neoplatónica; o Epigrama 38, em que Barbosa se exorta a si mesmo a superar as preocupações da vida, pela constância na luta; o Epigrama 4, acerca do nome de Jesus, que é a sua profissão de fé; o 6, sob a forma de epitáfio à sua esposa, que nos informa sobre a sua origem nobre e sobre o número de filhos do poeta; e o Epigrama 32, dedicado ao Príncipe D. Teodósio, em que o humanista aveirense se refere à sua própria cegueira prematura.

Entre todos os poemas autobiográficos, impõe-se o epigrama no 2 pela sua feição profundamente lírica, que faz dele, a nosso ver, a melhor composição de Aires Barbosa neste género. Nele exprime o poeta os sentimentos de saudade que o dominam na hora da despedida da cidade de Salamanca e do seu Estudo Geral, a quem ele dera, durante perto de trinta anos de magistério, o melhor do seu esforço inteletual e donde parte agora, no ano da sua jubilação, de volta definitiva ao recolhimento da pátria:

\section{AD VRBEM CELEBREM SALMANTICENSEM}

Dum stabant solidae puerili in corpore uires et calidus iuueni dum sanguis erat, non ego laedebar gelidis, Salmantica, uentis, non niue, non glacie, non aquilone tuo.

$\mathrm{Nec}$ me terrebat concrescens frigore Tormis, sub pede non udo qui mibi saepe fuit.

Nunc sanguis gelidus tepido meus orbe foueri, externique petunt membra caloris opem.

Grus te, Nile, bibit tepidum, quo tempore nobis

frigore concretas urna propinat aquas.

Idem, cum Libye flagrantibus aestuat horis, sidus in arctoum temperiemque uolat.

Et brumam fugitat per rura tepentia pastor et ueniente nouo uere reducit oues. 
Quid sibi conueniat, sibi quidue sit utile, cernit mutum animal melius lanigerumque pecus.

Namque homo, sit quanquam compos rationis, adhaeret aestibus in patriae frigoribusque suae.

Debuit a mutis didicisse animalibus omne esse solum patriam, sint ubicumque bona.

Propterea, mea blanda altrix Salmantica, quae me iam rude donatum quolibet ire sinis, cui dedimus nostrae melioris tempora uitae, ad te dum per nos utraque lingua uenit, frigora deuito quae non nocuere iuuentae, longaeuo sunt nocitura seni.

\section{À Famosa Cidade de Salamanca}

No tempo em que as forças vigoravam sólidas no meu corpo de rapaz e em que eu possuía o sangue fogoso da minha juventude, não me atingiam, Salamanca, nem o gelo dos teus ventos, nem a neve ou a geada, nem o teu Aquilão.

Nem me aterrava o Tormes a congelar de frio e que eu muitas vezes calcorreava com desprezo a pé enxuto.

Agora, meu sangue regelado reclama que o aqueça uma região temperada, e meus membros a ajuda de um calor estrangeiro. O grou bebe, ó Nilo, tuas águas tépidas no tempo em que a ânfora nos propina a água congelada pelo frio. E o mesmo grou, quando a Líbia é um braseiro em sua estação escaldante, voa para o clima e a temperatura do Ártico.

O pastor procura escapar à invernia através dos tépidos campos e, com a vinda da nova primavera, traz de volta o seu rebanho.

Melhor distinguem o que a si convém ou lhes traz utilidade o mudo animal e a rês lanígera, pois que o homem, sendo embora dotado de razão, fica preso às ardências e friúras da sua pátria.

Deveria ele aprender, dos mudos animais, que a pátria é todo o chão onde quer que se encontre a felicidade. Por isso, Salamanca, minha ama carinhosa que, agora jubilado, me deixas partir para onde eu quiser e a quem dedicámos o melhor tempo da nossa vida enquanto, por nosso intermédio, chegaram a ti as duas línguas, eis que fujo das friúras que não fizeram mal à juventude, mas que hão de fazê-lo a um velho de longa idade.

Todavia, a grande maioria dos epigramas do humanista é de conteúdo satírico. Trata-se por vezes de uma crítica de caráter pessoal, por exemplo 
quando ataca ou se defende dos seus detratores (Epigramas 3, 11, 16 e 49); noutros casos é a crítica de costumes (Epigramas 7, 8 e 13, de sátira feminina), a denúncia dos vícios da vida académica (Epigrama 10, contra o suborno na eleição dos professores; Epigrama 25, contra a boémia estudantil) e da Corte (Epigrama 11), ou de aspetos da sociologia religiosa (Epigrama 17, de crítica aos judeus conversos).

A maior parte, porém, dos epigramas satíricos do Mestre Grego tem por objetivo a luta persistente por ele travada contra a barbárie ancestral e generalizada nos meios "culturais" do seu tempo, na sequência do mesmo esforço encetado por humanistas italianos como Lourenço Valla ${ }^{4}$, Ângelo Policiano $^{5}$ e outros, e por espanhóis como António de Nebrija ${ }^{6}$.

Este combate humanístico registado na poesia de Barbosa abria-se em múltiplas frentes a revestia-se de vários aspetos: contra a preponderância dos juristas e canonistas, que depreciavam o estudo científico das línguas clássicas e cuja incultura e deturpação do próprio sentido das leis e da justiça Barbosa condenava (Epigramas 14, 15, 26, 27 e 48); contra os que desprezavam a função do "gramático" e contra a querela gramatical que se gerava em torno de matérias por vezes insignificantes (Epigramas 12, 28, 29 e 34); contra a ciência de lombada de certos pseudobibliófilos, contra a soberba dos autodidatas, a crendice dos astrólogos e os inimigos de Cícero (Epigramas 19, 24, 37 e 48). E não faltam as lamentações, em tom por vezes jocoso mas incisivo, de como era mal remunerado o trabalho árduo dos literatos, em comparação com as facilidades económicas concedidas a gente semissábia como juristas, canonistas e médicos (vd. os dois Epigramas 20 e 31 dirigidos ao arcebispo de Compostela e o Epigrama 22 a Jorge de Miranda).

De todos os poemas de conteúdo antibarbárico, o mais significativo é a seguinte composição (Epigrama 5) dirigida à juventude de Salamanca, em que Barbosa define, em termos bélicos, o objetivo deste combate, identificando o inimigo e exortando os jovens à vitória final.

\section{AD IVVENES STVDIOSOS}

\section{Barbariam geminis superauit Graecia lustris, bic nec barbaries post duo lustra cadit. At cur hoc, iunenes? - Quia sunt ex hostibus ipsis}

\footnotetext{
${ }^{4}$ Vd. a sua Epistola apologetica a João Serra sobre o objetivo dos Elegantiarum linguae latinae libri VI. Cf. Lourenço Valla, Opera omnia, II, Turim, R. Sabbadini, 1962, p. 390.

${ }^{5}$ Veja-se sobretudo a sua preleção chamada Lamia (vd. Angeli Politiani Opera, Tom. III, Lião, 1537, pp. 3-28).

${ }^{6}$ Sobre a ação deste mestre salmantino contra o obscurantismo linguístico dos gramáticos medievais, vd. o trabalho de Francisco Rico, Nebrija frente a los bárbaros. El canon de gramáticos nefastos en las polémicas del humanismo. Salamanca, 1978.
} 
qui uestras classes, agmina quique regunt.

Non horum ingenium prosa est uel carmine cultum,

bi fari Latie dedecus esse putant.

Nam, si quis Latium uerbum tentauerit, illum

ut stolidum irrident grammaticumque uocant.

Iam monstri simile est hos inter Graeca sonare

ac mula feta mirius illud opus.

Praeterea auctores uarios percurrite: cedunt non uni solum barbara castra duci.

Non uno uicit Troiam duce Graecia: multi conuenere illuc egregiique duces.

Et tamen Atrides plures sibi Nestoras optat conferri, ut citius Pergama uicta cadant.

Vnus enim (ut Graeci perbibent) quasi nullus habetur, sit clarus, praestans, eximiusue licet.

Vndique collatis in robur uiribus unum, quod plures tollunt, non leuat unus, onus.

Singula nulla queunt Histrum complere capacem flumina: collectis undique crescit aquis.

Nec leuiter Graiam, iuuenes, cognoscite linguam. Nam sine fontana riuulus aret aqua.

Te, Cicero, haec fertur sacris aluisse papillis, ex hac mox tenero lac bibit ore Maro.

Sed quid ego refero magnae duo lumina Romae quos fecit tantos Graecia sola uiros?

Quisquis inauctorum doctorum scribitur albo, buius nutritus nectare, morte uacat.

Haec hominum, illa Dei. tituli fuit illa secunda in cruce, prima Nouae Legis origo fuit.

Adde quod, ut quondam Nelides uincere Graios exhortabatur non spoliare senex, sic uos barbariae uictae decus ante uelitis.

Victa ipsa exuuias et spolia ampla dabit.

Nunquam doctus erit, studium sit an utile, quisquis sollicitis auidus computat articulis.

Hoc pacto, iuuenes, celeri uictoria cursu ornabit uestras fronde uirente comas.

At nunc barbariam decimo nec uincitis anno, bis decimo sic uos uincere posse nego.

\section{Aos Jovens Estudantes}

A Grécia venceu a barbárie em dois lustros, mas aqui nem depois de dois lustros ela cai.

E porquê, jovens? - Porque são dos próprios inimigos 
aqueles que comandam vossas esquadras e vossos batalhões.

$\mathrm{O}$ seu engenho não cultiva nem a prosa nem o verso; consideram que é uma desonra falar em latim.

Se alguém, de facto, tentar dizer uma palavra latina, riem dele como de um louco e chamam-no gramático. E então ouvir sons gregos no meio deles é como se fosse um fenómeno, isso é obra de maior espanto que mula prenhe.

Além disso, percorrei os variados autores: os acampamentos da barbárie não cedem perante apenas um capitão sozinho.

Não foi com um só capitão que a Grécia venceu Troia: juntaram-se lá muitos e egrégios capitães. E, todavia, o Atrida deseja que lhe tragam mais Nestores, para que Pérgamo mais depressa caia vencida.

É que um só (no dizer dos Gregos) é como se não fosse nenhum, mesmo que ele seja ilustre, eminente e exímio.

Um só, ainda que reúna toda a energia numa única força, não ergue o peso que muitos levantam.

Nenhum dos vários afluentes consegue encher o caudal

do Istro: este cresce quando se juntam as águas de toda a parte.

Procurai, jovens, conhecer a fundo a língua grega, pois sem a água da fonte fica seco o ribeiro.

Dizem que foi ela, ó Cícero, que te alimentou em seus peitos sagrados, e Marão dela bebeu o leite logo desde tenra boca.

Mas porque refiro eu os dois luminares da magnífica Roma, aos quais só a Grécia tornou tamanhos?

É que todo aquele que, nutrido pelo néctar desta língua, se inscrever no álbum dos sábios autores, da morte se liberta. Ela foi dos homens, ela foi de Deus, ela foi a segunda do título de condenação na cruz: foi a primeira origem da Nova Lei.

Mais ainda: tal como outrora o velho Nelida exortava os Gregos a vencerem e não a espoliarem, assim vós desejai, acima de tudo, a honra de terem vencido a barbárie, que ela, depois de vencida, dar-vos-á presas e amplos despojos. Nunca será douto quem quer que, na sua avidez, faça contas com seus dedos agitados a ver se o estudo the traz lucros.

Desta maneira, jovens, a vitória virá em passo veloz e ornará a vossa cabeça com uma verdejante grinalda.

Mas se, agora, em dez anos a barbárie não venceis, eu vos digo que também a não podeis vencer em duas vezes dez.

São de caráter político onze das poesias finais da presente coleção, compostas a propósito da revolta das Comunidades de Castela, da guerra da Espanha com a França, do avanço dos Turcos sobre o Ocidente europeu e das rivalidades sangrentas entre os Estados cristãos da Europa. 
Sobre o tema da revolta dos comuneros em Castela - que Aires Barbosa designa genericamente por Democratia - escreveu o nosso humanista os Epigramas 16 e de 39 a 44.

A sua atitude perante esta revolução democrática, que em Espanha se prolongou pelos anos de 1520 e 1521, nem sempre é muito clara. Sabe-se que este movimento, embora de iniciativa predominantemente popular, não se dirigia inicialmente contra a nobreza, mas visava apenas a política governativa de Carlos V, que impôs à Espanha um governo de figuras estrangeiras chefiado pelo flamengo Adriano de Utrech; onerou os impostos públicos e, com a sua ausência prolongada, deixava o país na dependência da política geral do Império ${ }^{7}$. De resto, havia mesmo várias figuras nobres de militares e civis e de literatos ${ }^{8}$ empenhados nesta rebelião; e os próprios clérigos estiveram na sua origem em algumas cidades ${ }^{9}$.

A partir, porém, da altura em que o movimento de reivindicações se foi transformando e adquirindo um caráter verdadeiramente revolucionário que pretendia a participação do poder e fazia, inclusivamente, depender a autoridade régia do poder do Reino, isto é, do povo -, desde então, os nobres começaram a pressentir o perigo que os seus próprios interesses corriam e desligaram-se da revolução. $\mathrm{O}$ exército real reorganizou-se, e a revolta das Comunidades acabou por ser dominada na batalha de Villalar em 23 de Abril de 1521.

Aires Barbosa parece acompanhar nos seus poemas esta evolução política.

De facto, no Epigrama 39, escrito em 1520, o humanista exalta a "Democracia", considerando-a um acontecimento que a posteridade recordará com prazer e comparando-a com os movimentos de emancipação dos povos peninsulares contra o jugo romano da história passada. No Epigrama 40, Barbosa evoca a aliança das cidades de Castela firmada num juramento coletivo, provavelmente aquela donde resultou a chamada Santa Junta instituída em Ávila em 1 de agosto de 1520; enumera algumas das principais cidades que aderiram à conjuração e - se bem interpretamos - parece apontar como causa fundamental deste movimento revolucionário o facto de Carlos V, rei de Castela e Aragão desde 1517, ter abandonado o país pouco depois da sua chegada à Espanha, por ter sido, entretanto, nomeado imperador do

${ }^{7} \mathrm{Vd}$. o estudo desenvolvido de Joseph Pérez, La révolution des "Comunidades" de Castille (1520-1521), Institut d'Études Ibériques et Ibéro-Américaines de l'Université de Bordeaux, 1970.

${ }^{8}$ Sobre a adesão, por exemplo, da Universidade de Alcalá e dos seus professores Florián de Ocampo e Hernán Núñez - o célebre humanista Comendador Grego - à revolta de Toledo, vd. Joseph Pérez, op. cit. pp. 332 sqq.

${ }_{9}^{9}$ É o caso de um grupo de padres franciscanos de Salamanca, que em Fevereiro de 1520 elaborou um plano de reivindicações às Cortes anunciadas por Carlos V, que veio depois a constituir o programa da revolução das Comunidades. Vd. idem, ibid., pp. 148 sqq. 
Sacro Império Romano-Germânico ${ }^{10}$. O humanista condena esta atitude de Carlos V e refere-se-lhe numa linguagem metafórica - o rei era a cabeça de um corpo invicto, que, arrancada dos seus membros, o deixou, segundo dizem, abandonado -, linguagem que termina com palavras de particular violência: "Creio que tal cabeça - diz o poeta - andaria melhor na sola dos pés" (Cf. Epigrama 40, v. 17). Barbosa parece estar, neste momento, ainda do lado da revolução.

Porém, onde as suas ideias sócio-políticas se mostram bem demarcadas é no Epigrama 42, em que ele faz uma exortação e ao mesmo tempo uma advertência à "Democracia". O humanista condena o movimento revolucionário por este não aceitar as iniciativas e condições de paz propostas pelo imperador e pelos nobres, nas vésperas da batalha decisiva de Villalar, que havia de trazer a derrota dos comuneros e o fim da guerra das Comunidades. Barbosa chama a atenção dos revoltosos para a disparidade de forças entre eles e o poder real, que fatalmente os esmagará; exorta-os a não desperdiçarem esta ocasião de paz, e adverte-os da ruína que os espera. $\mathrm{O}$ humanista termina com palavras de uma dureza que denuncia a sua radical mentalidade aristocrática. Para ele, o governo do país pertence aos nobres, o "vil trabalho" pertence à "vil ralé".

Podemos dizer que Aires Barbosa, neste processo político da revolução comunera, se manteve sempre do lado da aristocracia: apoiou-a na primeira fase da luta quando nesta participava a nobreza, que se sentia lesada pelas medidas políticas de Carlos V, o qual, ao impor aos castelhanos um governo estrangeiro integrado por elementos da sua comitiva flamenga, feriu o orgulho das tradições nobiliárquicas de Espanha; na segunda fase, o Mestre Grego virou-se contra os revoltosos para novamente defender os nobres, que, ao verem perigar os seus próprios interesses materiais e de classe perante os projetos profundamente revolucionários que a guerra passou a alimentar, decidiram dar o seu apoio definitivo a Carlos V.

Os Epigramas 43 e 44, dirigidos ao alcaide da fortaleza de Alaéjos, António de Fonseca, têm particular interesse por apresentarem a faceta moderada de Aires Barbosa. Por um lado, na primeira dessas composições, o Autor exalta a bravura do alcaide, que se mostrou um valoroso capitão na defesa daquele castelo quando os comuneros o submeteram a um prolongado cerco, como represália do incêndio de Medina del Campo, de 21 de agosto de 1520, ateado pelas tropas reais sob o comando de António de Fonseca incêndio que havia provocado um protesto geral em toda a Espanha, incluindo

${ }^{10}$ Carlos V, que se encontrava em Espanha desde Outubro de 1517, foi eleito imperador em 28 de Junho de 1519 em Frankfurt e partiu para a Alemanha em 20 de Maio de 1520 a fim de receber a coroação imperial. 
os nobres e a população favorável a Carlos V. ${ }^{11}$

Por outro lado, o humanista condena, no segundo destes epigramas, a perseguição e mortandade a que o mesmo alcaide, levado pelo desejo de glória, sujeitou os inimigos seus compatriotas, durante uma cilada preparada no interior do próprio castelo.

O segundo aspeto da intervenção política da poesia de Aires Barbosa tem a ver com o conflito militar surgido entre a Espanha e a França em 1521 a propósito dos interesses políticos de uma e outra sobre o reino de Navarra.

Barbosa dedica a este tema os Epigramas 45, 46 e 47, nos quais o poeta, mais do que um íncola passageiro em terras castelhanas, se mostra um verdadeiro patriota a encarar como qualquer espanhol nativo a sua arreigada francofobia.

No Epigrama 45, o Autor faz um apelo às armas e exorta toda a Espanha a acabar com as guerras fratricidas das revoluções internas e a congregar-se num esforço unitário de defesa nacional contra a invasão francesa no reino de Navarra. O Epigrama 46 evoca a recuperação da fortaleza de Fuenterrabía em 1524, e o epigrama 47 celebra a vitória da nobreza espanhola em Logronho na retomada desta cidade em 1521 por ocasião da contraofensiva das tropas de Carlos V frente à invasão de Francisco I em Navarra, depois de dominada já a guerra dos comuneros em Castela.

O quinquagésimo e último epigrama desta coleção de Aires Barbosa é uma crítica aos máximos responsáveis políticos e religiosos da Cristandade europeia, que se digladiavam em lutas fratricidas permanentes e davam com isso ocasião aos Turcos de avançarem sobre os Estados cristãos. São evocadas neste epigrama a tomada de Rodes em 1522 e a da Hungria em 1526 pelo sultão Solimão II. Barbosa termina com uma referência amarga ao escândalo que constituiu o tristemente célebre Saque de Roma, resultante das hostilidades entre Francisco I de França e Carlos V e levado a cabo em 1527 pelas "cristianíssimas" tropas do Imperador, e a cujos massacres e vandalismo nem o Papa escapou.

A análise deste meio cento de epigramas latinos do Mestre Grego - que o foi de ambas as línguas - mostra que ele não era apenas um técnico do ensino, mas tinha franca propensão para a arte literária e dominava em particular este género de poesia.

É certo que boa parte destas composições, sob o ponto de vista estético, talvez digam pouco à nossa sensibilidade artística moderna. Mas isso acontece em relação à maior parte dos escritores neolatinos, e não se deve apenas a limitações objetivas da sua produção literária, mas também, e talvez em primeiro lugar, à incapacidade da crítica moderna.

11 Vd. Joseph Pérez, op. cit., pp. 178-181. 
Por um lado, os padrões artísticos e literários da época do Renascimento não eram os mesmos de hoje; por outro, naquela época cultivava-se e apreciava-se de uma maneira particular o valor estético da própria língua latina, independentemente do conteúdo artístico da mensagem. Ora, esse valor é hoje cada vez mais impossível de captar em razão do limitado conhecimento daquele idioma, que serviu de veículo ao vastíssimo campo da literatura neolatina portuguesa, depositária e transmissora de uma parte importantíssima da nossa cultura nacional.

Aires Barbosa tem muitos poemas de real conteúdo estético, apesar de alguns deles se imporem principalmente pela sua beleza formal. Repete os mesmos hábitos frequentes entre os poetas do Renascimento, tais como a imitação, muitas vezes quase servil, dos modelos antigos e o recurso constante à mitologia e a outros topoi da literatura clássica.

Assim mesmo, ainda é nos epigramas e em outras pequenas composições de circunstância dispersas por obras suas e de amigos, que encontramos a melhor poesia de Aires Barbosa, sobretudo quando as comparamos com certos poemas didáticos que integram as releções da Epometria, da Prosodia e da Ortographia e com a própria Antimoria, que se prendem a um estilo necessariamente mais prosaico.

Finalmente, o professor e filólogo - o Mestre Grego - Aires Barbosa mostra em muitos destes epigramas que a expressão das suas preocupações pedagógicas e didáticas não se limitava ao trabalho letivo e às releções dele resultantes, mas passava também por grande parte da sua excelente produção poética, que faz dele sem dúvida o primeiro dos grandes humanistas portugueses. 


\title{
A Viagem Marítima como Metáfora da Criação Literária: o Exemplo Paradigmático do Humanista Aires Barbosa
}

\author{
Sebastião Tavares de Pinho \\ Universidade de Coimbra
}

- Então, ti Manel, como vai a vida?

- Cá vamos, meu amigo, ... tocando o barco.

"Tocando o barco" - uma expressão das mais recorrentes na linguagem popular e com raízes que se perdem na penumbra do tempo; uma metáfora herdada do campo da viagem náutica e de grande fortuna entre povos marinheiros, como eram os gregos e os latinos, de quem recebemos as bases da nossa cultura e, como eles, possuímos a mesma vocação marítima. Ela aparece com variadas aplicações, desde o sentido do decurso da vida, pessoal ou social e política, passando pela vivência amorosa expressa na obra dos poetas líricos, e sobretudo como imagem da gestação e criação literária. Mas sempre com o sentido geral de dificuldade, esforço e perigo, na luta genérica da experiência existencial, no desconcerto de amores e desamores, na utopia da governança e do poder, e no próprio desforço e nas dores de dar à luz uma obra escrita.

De tudo isto encontramos na história da literatura, desde as nossas fontes primordiais, sobretudo greco-latinas.

A metáfora da nau do Estado, por exemplo, que faz da vida política um percurso náutico e de quem governa um timoneiro, remonta ao séc. VII a. C. na voz do poeta Arquíloco (fr. 56 Diehl); tornou-se famosa mais tarde através dos poemas de Alceu (fr. 326 Lobel-Page); nela se baseou, quatro séculos depois, o poeta latino Horácio na sua alegoria da nau da república nos 20 versos da Ode I, 14, que se tornou famosa a ponto de, pouco depois, Quintiliano tê-la tomado como modelo, ao definir o conceito de alegoria. Mas, ainda na literatura grega, encontramos, por exemplo, na Antígona de Sófocles (séc. V a. C.) pelo menos quatro passos desta mesma metáfora náutica; e um caso de extrema expressividade é o da tragédia Sete contra Tebas, de Ésquilo, (séc. VI-V a. C.) em que Etéocles se apresenta como um almirante agarrado ao timão da cidade de Tebas metaforizada em navio acossado pela armada inimiga, e que os analistas chamam a "nau da maldição"1. Como metáfora da escrita, o comediógrafo Aristófanes (séc. V-IV a. C.) em Os Cavaleiros (vv. 541-544), toma a carreira do marujo a bordo como metáfora da vida e da carreira do dramaturgo ${ }^{2}$.

\footnotetext{
${ }^{1}$ Cf. Maria do Céu Zambujo Fialho. A Nau da Maldição. Estudos sobre Sete contra Tebas de Ésquilo. Coimbra: Minerva, 1996, p. 77 sgs.

${ }^{2}$ Cf. Maria de Fátima Sousa e Silva. Os Cavaleiros de Aristófanes. Introdução, versão do grego e notas. Coimbra: Centro de Estudos Clássicos e Humanísticos da Universidade de Coimbra, 1985, p. 70.
} 
$\mathrm{Na}$ literatura latina é abundantíssima a mesma metáfora nos vários campos em que ela funciona, entre os quais avulta o de elemento comparante da criação literária. É muito frequente ver um escritor a "enfunar as velas da oratória”, como se vê em Cícero (Tusculanas, IV, 5, 9), a largar as velas (vela dare) ao mar da produção poética, como em Virgílio nas Geórgicas (II, 3946), ou a recolher as velas (vela trahere) para terminar um excurso narrativo (ibidem, IV, 116-117). Ovídio é o poeta latino que porventura mais se serve da metáfora náutica para símbolo da escrita. Só na Arte de Amar, nos Tristia e nos Fastos, é possível encontrar mais de uma dezena de exemplos desse recurso. O mesmo se diga dos poetas Propércio e Estácio e mesmo dos prosadores Tito Lívio e Plínio-o-Moço.

De todos os autores portugueses em cuja obra encontrámos registada a metáfora náutica da criação literária, aquele que mais longa e expressamente a utilizou foi Aires Barbosa. Nascido por volta de 1475, em Esgueira, junto de Aveiro, estudou durante cerca de seis anos na Universidade de Florença, onde conheceu grandes mestres do humanismo italiano, como Hermolao Barbaro, Pico della Mirandola e Ângelo Policiano, de quem foi aluno assíduo, e onde teve por condiscípulo João de Médicis, futuro papa Leão X. Regressado a Portugal em 1495 como mestre graduado e especializado em línguas e literaturas clássicas, logo ingressou no corpo docente da Universidade de Salamanca, para aí se dedicar ao ensino da Retórica e das Humanidades. Tornou-se particularmente famoso como o primeiro professor da língua de Homero, pelo que ficou conhecido pela honrosa antonomásia de "Mestre Grego", como ainda hoje se pode ver na documentação universitária da época, e mereceu dos críticos modernos o apelido de "patriarca do helenismo ibérico". Depois de vinte e oito anos de trabalho letivo na cidade do Tormes, aí jubilou em 1523 e, a convite de D. João III, regressou a Portugal e passou a trabalhar no âmbito da corte como mestre dos irmãos do monarca português até 1530, ano em que pediu escusa dessas funções para passar os últimos dez anos de vida na sua terra natal.

Aires Barbosa, além de professor, foi também um excelente poeta latino, em que se notabilizou pelo poema Antimoria, de oposição ao "Elogio da Loucura" (Moriae Encomium) de Erasmo e deixou publicados mais de cem epigramas de tema variado. Mas as suas principais publicações têm caráter didático e filológico e são resultado de uma boa parte dos cursos que ele lecionou em Samalanca: um tratado sobre os verbos oblíquos (In verba M. Fabii, Quid quod et reliqua. Relectio de verbis obliquis, Salamanca, 1511); um compêndio de métrica, com o neologismo Epometria a servir de título (Relectio cui titulus Epometria, Salamanca, 1515); um volumoso comentário filológico ao poema Historia Apostolica de Arátor, que é a sua obra de maior vulto e importância (Aratoris Cardinalis Historia Apostolica cum Comentariis, Salamanca, 1516) e 
dois tratados conjuntos publicados em 1517, um sobre prosódia (Relectio cui titulus Prosodia) e outro sobre ortografia (Relectio cui titulus Orthographia).

Ora, grande parte destas obras exemplificam o frequente recurso de Aires Barbosa à referida metáfora náutica, com a aplicação de algumas das suas diversas funções estético-semânticas.

Uma delas é a que pretende simbolizar o comportamento do homem perante a complexidade da vida e a própria arte da existencialidade humana, que tantas vezes exige uma especial ginástica psicológica, que todos conhecemos. É nesse sentido que o poeta se dirige a si próprio, no epigrama 38 da coleção dos cinquenta publicados na tipografia dos monges de Santa Cruz de Coimbra, em 1536, quando se recolhera definitivamente à sua terra de Esgueira e aproveitara o remanso da jubilação para reunir e publicar as suas poesias inéditas ${ }^{3}$ :

\section{Ad se Paraenesis}

Rector ut in tumido puppim regit aequore gnarus

Quos uitet scopulos, quae loca tuta petat,

Frangit et hanc, buic cedit aquae, moderamine claui,

Infirmam tabulam per freta longa uehit,

Sic et, Ari, motus animi fluctusque tumentes

Nunc preme, nunc laxa, sub ratione tenens.

Indomitumque salum uitae uirtute gubernans,

Sic supera curas, ut maris ille minas.

Auto-exortação

[A NAU DA VIDA]

Tal como o piloto governa a popa no mar inchado, sabendo

Os escolhos de que deve fugir e os lugares seguros para onde rumar,

E, rompendo umas ondas e cedendo a outras com o governo do leme,

Conduz seu débil lenho através dos longos estreitos,

Assim também tu, Aires, ora aperta ora afrouxa a agitação

$\mathrm{E}$ os turbilhões entumecidos da alma, dominando-os com a razão.

$\mathrm{E}$, governando com denodo as indómitas vagas da vida,

Teus cuidados supera, tal como aquele as ameaças do mar.

Mas é sobretudo no sentido de criação e composição literária que a mesma metáfora da viagem náutica surge na obra do nosso humanista, como se vê logo no primeiro opúsculo pedagógico, publicado nos idos de junho de 1511, sobre

${ }^{3}$ Vd. Aires Barbosa. Arii Barvosae eiusdem Antimoria et nonnulla epigrammata. Coimbra: Mosteiro de Santa Cruz, 1536, fol. XXXX. 
os referidos verbos oblíquos, ou impessoais como diríamos hoje, do tipo oportet, licet, piget, etc., em que, ao concluir as páginas introdutórias sobre os motivos e a oportunidade desta obra, dá início à discussão do tema antecedendo-a das seguintes palavras, em que se mistura uma invocação às entidades divinas protetoras e inspiradoras da atividade da escrita com a linguagem metafórica da viagem marítima em que ela se desenvolve:

[...] Sed prius quidem te, Christe Theanthrope Liberator noster teque Deipara Virgo in huius actionis exordio inuoco; uos mibi clarissimi septentriones, ad quorum lumen in occiduum nostrae cymbae clauus dirigitur; uos mibi aeterni ignes, quorum fulgor nunquam occidit, semper lucet: Vos ego ueneror uestrum numen supplex imploro ${ }^{4}$.

"Mas, antes de mais, no exórdio desta demanda, quero invocar-vos, ó Cristo, Deus Humanado, Nosso Salvador, e a Vós, Virgem Mãe de Deus; a vós, que sois as minhas claríssimas estrelas do Norte, sob cuja luz o leme da minha barca se dirige para as águas do poente; a vós que sois meus eternos luzeiros, cujo fulgor nunca se põe e me alumia sem cessar; a Vós me dirijo e, suplicante, imploro o vosso divino poder."

É com esta invocação, de estrutura clássica mas de conteúdo cristão, numa simbiose, ou antes, numa substituição do maravilhoso pagão pelas referências de motivação cristã, como tantas vezes acontece na literatura do Renascimento, que Aires Barbosa desenvolve este seu tratado, e como se fosse numa viagem de barco para os lados do Ocidente (in occiduum), isto é, através do oceano Atlântico na perspetiva geográfica dum professor da vetusta universidade de Salamanca e num tempo áureo de descobertas ocidentais.

A mesma metáfora marítima aparece, em idênticas circunstâncias, no tratado da Ortografia do mesmo Aires Barbosa, publicado em dezembro de 1517, numa edição conjunta com o tratado da Prosódia, que o antecede. É no fim da introdução do tratado da Ortografia que o nosso humanista compõe um pequeno poema de catorze hexâmetros, que assume a forma de invocação, mais uma vez, às entidades do Criador, do Espírito Sagrado e sobretudo da Virgem Maria, no contexto metafórico de uma viagem náutica, desta feita de forma muito mais explícita e expressiva ${ }^{5}$ :

Sed sine te, quoniam mens nil, bone Conditor, audet

Nostra, nec exiguum, in montes mea lumina tollo,

\footnotetext{
${ }^{4} \mathrm{Vd}$. Aires Barbosa. In verba M. Fabii Quid? quod et reliqua. Relectio de verbis obliquis. Salamanca, 1511, fol. a ij v.

${ }^{5}$ Vd. Aires Barbosa. Relectio cui titulus Prosodia [et] Relectio cui titulus Orthographia, Eiusdem Arii B. nonnulla epigrammata. Salamanca, 1517 , fol. b vj v.
} 
Vnde mibi auxilium ueniat. Da Spiritus auram

(En totas illi uelorum pandimus alas)

Sancte, tuam, flatuque sinus implere secundo

Dignare, omnipotens. At tu, sacra sponsa Tonantis,

Cui flos cum tanto fructu contexitur, hoc est

Dulce decus matris cum uirginitatis honore

Vnica coniungens, nobis succurre, tuoque

Vultu tellurem, caelum, mare, cuncta serena.

Ipsa pia lege uela manu, uel lintea flabris

Pandito, uel clauum residens in puppe guberna.

Quidquid ages, sancto mea numine tuta sub isto

Nauis, et optatum portum, et sua litora tanget.

"Mas porque sem ti, meu bom Criador, a nossa mente

Nada ousa nem mesmo exíguo, ergo meus olhos para os montes

Donde me possa vir auxílio. Concedei-me, Espírito Sagrado,

Vossa aura (eis que lhe abrimos inteiramente as asas

Das nossas velas) e dignai-vos encher seu côncavo com o vosso

Favorável sopro, Deus omnipotente. E vós, sacra esposa do Tonante,

Cuja flor se entretece com tamanho fruto, isto é,

Vós que sois a única a juntar a doce glória de Mãe

Com a honra da virgindade, socorrei-nos e, com vosso

Vulto, a terra, o céu, o mar, a tudo serenai.

Recolhei com vossa mão piedosa as próprias velas, ou abri

aos ventos as telas de linho, ou, postada à popa, sede vós a timoneira.

Façais o que fizerdes, a minha nau, sob a tutela de vosso sagrado

Poder, há de surgir nas praias do porto desejado."

Mas o recurso mais desenvolvido à viagem marítima como expressão metafórica da criação e composição literária apresenta-se no longo Comentário feito por Aires Barbosa a Arátor, escritor dos séculos V-VI e cardeal do papa Vigílio, que figura entre os poetas cristãos continuadores dos cânones da poesia clássica e que compôs um poema de cerca de 2000 versos sobre o texto neotestamentário dos Atos dos Apóstolos, num estilo épico ao modo virgiliano. A obra divide-se em dois livros, sendo o primeiro dedicado aos feitos do apóstolo Pedro e o segundo aos atos de Paulo. O próprio conteúdo deste poema e as circunstâncias que levaram Barbosa a comentá-lo explicam o uso exaustivo daquela metáfora em que o autor envolveu o seu trabalho.

De facto, tratando-se de uma composição de estilo místico, frequentemente simbólico e de um acentuado hermetismo e por isso de difícil interpretação, Aires Barbosa entendeu que era um bom texto para objeto de comentário filológico segundo as novas técnicas das escolas renascentistas 
em que ele se formara, começando pela crítica textual seguida da hermenêutica e da crítica literária, segundo o mesmo processo de análise aplicado aos autores clássicos. Esse trabalho foi desenvolvido durante um curso letivo, por volta do ano académico 1512-1513. E, três anos depois, e por reiterada insistência dos alunos que o frequentaram e para avivar a memória destes e benefício dos que não tinham tido esse privilégio, o Mestre Grego decide publicá-lo. Ora, a consciência da particular dificuldade hermenêutica desta obra foi uma das razões que levaram o humanista a comparar essa tarefa a uma longa e penosa viagem pelo mar com todas as intempéries e perigos que a acompanham.

Logo à cabeça do prefácio do longo Comentário, Barbosa reconhece que a sua publicação servirá não só para reavivar a memória dos alunos, "mas também para benefício, a bem dizer, de todos e cada um dos estudiosos das belas-letras, que não ousam penetrar na própria obra de Arátor como se ela fosse num pélago profundo": sed etiam cunctis fere studiosis bonarum litterarum, qui ipsum Aratoris opus non audent tanquam profundum pelagus intrare ${ }^{6}$.

E para confirmar o caráter hermético do poema de Arátor e o particular esforço que o seu comentário exige e que tem demovido outros filólogos de ousarem fazê-lo, Barbosa não se coíbe de estabelecer o seu confronto com a poesia, bem mais fácil, de três poetas da mesma época e igualmente cristãos, todos nascidos na Hispânia, e cuja obra havia sido recentemente comentada por outros, designadamente pelo seu colega, António de Nebrija, com quem conviveu e manteve alguma mais ou menos delicada rivalidade. Diz Barbosa:

Cum enim per reliquorum Christianorum uatum poemata, quasi per stagna quaedam, facile nauigent et Prudentii, Sedulii, Iunenci carmina suis discipulis exponant, uelut in portu uelificantes, adire ad hunc timent, uel, si adeunt, loca proxima et oras primi litoris tantum legunt, altum metuentes, et a terra nusquam longius recedentes?.

"Com efeito, apesar de navegarem com facilidade pelos poemas dos restantes vates cristãos, como quem atravessa certas lagoas de águas mansas, e embora expliquem aos seus discípulos os poemas de Prudêncio, de Sedúlio, de Juvenco, como se fosse a velejar dentro de um porto, deste têm eles medo de se aproximar e, se o fazem, costeiam apenas os lugares próximos e a borda da beira-mar, receando o mar alto e sem se afastarem, em nenhum ponto, para mais longe

${ }^{6}$ Vd. Aires Barbosa. Aratoris Cardinalis Historia Apostolica cum Commentariis. Salamanca: Juan de Porris, 1516, fol. ii.

${ }^{7}$ Vd. ibidem; cf. José Henrique Manso, Comentário de Aires Barbosa à Historia Apostolica de Arátor (Textos Preliminares e Primeira Seç̧ão do Livro I). Estudo Introdutório, Fixação do Texto, Tradução e Notas. Coimbra: Faculdade de Letras, 2001, pp 72-73 [tese de mestrado, policopiada]. 
da terra."

E com esta linguagem comparativa começa Barbosa a sua longa metáfora náutica, que se desdobra ocupando toda a estrutura do prefácio e se renova e estende repetidas vezes ao longo da obra inteira, numa complexa cadeia de recursos alegóricos. Assim, depois de um longo discurso colocado na boca dos seus alunos com grande cópia de argumentos para convencerem o Mestre Grego a publicar estes comentários, Barbosa, cede ao seu pedido, mas recorda-lhes a multiplicidade de perigos que essa aventura implica, deste modo:

Equidem ista audiens quibus ego (liceat concedere uerbis) assentior, morigerari uobis et uolo et cupio. Verum neutiquam uos fugit qua mibi sit nauigandum, quales et quam turbulentos uentorum flatus in isto mari procelloso, quam graues fluctus tortuosi turbinis, quam difficiles scopulos, quam multa loca aduersa et Scyllaeis canibus et naufragio obnoxia sim transmissurus. Non uos praeterit quoties nobis sit, prius quam ad optatae quietis sinum prouehamur, desperandum, quoties incerta spe nautarum in morem, et uotis magis quam fiducia nauigantes, uagi instabilesque uenti aut nos deserentes moraturi sint, aut in aduersam tempestatem nitentes longe a proposito nobis cursu depulsuri, praesertim cum meae infirmitatis hand nescius, aut quibus rudentibus malum, aut quibus ancoris nauim muniam incertus sim. ${ }^{8}$

"Certamente que, ao ouvir essas razões, com as quais (valha a verdade) eu estou inteiramente de acordo, é minha vontade e desejo procurar agradar-vos. Mas vós não ignorais de modo nenhum por onde eu tenho que navegar, quais e quão ciclónicas tempestades de ventos nesse mar de procelas, quão pesadas vagas de um recurvo turbilhão, quão difíceis escolhos e quantos lugares adversos e sujeitos aos cães de Cila e a naufrágio eu terei que atravessar. Não vos passará despercebido quantas vezes entraremos em desespero antes de atingirmos a enseada da apetecida tranquilidade, quantas vezes, com a esperança incerta como os marinheiros e navegando mais pelo anseio que pela confiança, os ventos vagabundos e instáveis ou, abandonando-nos, hão de deixar-nos parados, ou, forçando-nos contra a tempestade iminente, hão de afastar-nos para longe da derrota por nós traçada, mormente quando, tendo eu plena consciência da minha debilidade, não tenho certeza nem com que amarras hei de segurar o mastro nem com que âncoras defenderei a nau."

Mas, apesar deste quadro negro que, em tempo poético, Aires Barbosa antevê, ele assume a tarefa da composição e publicação desta sua obra como um seu dever cívico, académico e mesmo religioso, e assim decide:

Haec ego et his plura, quae me, ut mox ostendam, ab huius turbulenti maris ingressu

\footnotetext{
${ }^{8}$ Vd. Aires Barbosa. Aratoris Cardinalis..., fol. ii; cf. Manso, op. cit., pp.74-77.
} 
auertebant, mibi posthabenda duxi, ut Deo meo aliquo officii genere obsequerer, et ei obsequendo, uobis, auditores suauissimi, commodarem. ${ }^{9}$

"A estes obstáculos e muitos mais, que, como em breve mostrarei, me demoviam de entrar neste mar turbulento, entendi ser meu dever pô-los de parte, a fim de me dedicar ao meu Deus com algum tipo de tarefa e, ao dedicar-me a Ele, me colocar, amabilíssimos ouvintes, também ao vosso serviço.”

Dada, porém, a sua assumida fraqueza, o humanista recorre ao poder divino para implorar um especial auxílio, a fim de encetar esta viagem de gestação literária, tendo por fundo sempre a mesma imagem marítima:

Sed quia nostra fragilis ac minus firma nauis tot periculis aduersi gurgitis impar est, tuae maiestatis opem ante omnia imploramus, ut extensa tibi spei nostrae uela contra instabiles uentorum flatus stabili flatu spiritus tui impleas, atque ita impactas de te pendenti nauigio ponti minas frangas tu ad tutissimum portum optati litoris ipsum prosequare. ${ }^{10}$

"Mas porque a nossa barca, frágil e de fraca resistência, não pode ombrear com tantos perigos do sorvedouro que tem pela frente, imploramos antes de tudo a ajuda da Vossa Majestade, para que, contra os inconstantes sopros dos ventos, Vos digneis, com o constante sopro do vosso espírito, encher as velas da nossa esperança, para Vós estendidas, e quebrar as ameaças do oceano lançadas contra uma navegação de Vós dependente, de modo a acompanhá-la até ao seguríssimo porto da praia apetecida.”

Aires Barbosa aceita, com humildade, que este seu plano possa estar votado ao fracasso, por não ser digno do favor da ajuda divina e, nesse caso, admite, em termos retóricos e talvez em certo tom de ironia, que isso até poderá dar ocasião a que outro mais talentoso o possa substituir nesta viagem náutica de composição literária, quando afirma:

At etiam aliquis forte excitabitur naufragio meo qui Deo carior, ingenio sublimior, doctrina locupletior, uices tanti operis excipiat, quique certa superni numinis spe confirmatus, utilem uerae litteraturae candidatis nauigationem transigat. ${ }^{11}$

"E até se sentirá porventura estimulado com o meu naufrágio alguém que, sendo mais caro a Deus, mais sublime em talento, mais rico em conhecimentos, continue na minha vez o encargo de tamanha obra, e que, confirmado pela firme esperança do poder superno, leve a bom termo esta navegação útil aos

\footnotetext{
${ }^{9}$ Vd. Aires Barbosa. Aratoris Cardinalis..., fol. ii; cf. Manso, op. cit., pp. 76-77.

${ }^{10} \mathrm{Vd}$. Aires Barbosa. Aratoris Cardinalis..., fol. ii; cf. Manso, op. cit., pp. 76-77.

${ }^{11}$ Vd. Aires Barbosa. Aratoris Cardinalis..., fol. ii; cf. Manso, op. cit., pp. 76-77.
} 
candidatos da verdadeira literatura.”

Entretanto, e apesar de tudo, o humanista termina este longo prefácio com a firme disposição de entrar nas ondas encapeladas da redação e publicação dos comentários ao poema de Arátor, esquecendo todos os seus detratores, simbolizados mais uma vez na referência mitológica dos monstruosos cães de Cila:

At quoniam oportet (quemadmodum sapientes praecipiunt) ut templis uestibula et aditus sic scriptis nostris principia proportine respondere, non euagabor iam amplius, sed uno uerbo colligam, in calce professus huius exordii, me, ut talentum Dei mei aliquo lucello augeam, bono animo et hosce marinos fuctus ingredi, et quoscumque Scyllaeos latratus contemnere. Addetur autem aliquid talento, si uobis, auditores, plurimum mea commentatio profuerit. ${ }^{12}$

"Mas, visto que (conforme prescrevem os sábios), do mesmo modo que acontece nos vestíbulos e nas entradas em relação aos templos, também no começo da nossa obra escrita é necessário respeitar uma correspondência proporcional, não me alongarei em mais divagações, e, ao apresentar-me na meta final deste exórdio, concluirei, numa só palavra, que, para fazer crescer com algum pequeno lucro o talento que Deus me concedeu, é com a melhor disposição que avanço para dentro destas vagas marinhas e desprezo toda a espécie de latidos de Cila."

E deste modo Aires Barbosa dá início ao longo e minucioso comentário ao Livro I do poema de Arátor, feito palavra a palavra, num total de cerca de 1.100 hexâmetros heroicos distribuídos por 25 secções, correspondentes a outros tantos episódios ou atos do apóstolo Pedro.

Chegado ao fim desta primeira parte, prepara-se para o comentário ao Livro II, que é antecedido de um prefácio próprio, dirigido, tal como no primeiro, "aos jovens estudantes das belas-letras" e que retoma e desenvolve a metáfora náutica iniciada no prefácio do Livro I, desta vez ainda em termos ainda mais eloquentes, agora que o autor já experimentou o peso e as dificuldades da laboriosa tarefa de escritor e comentarista. Assim fala Barbosa aos seus alunos:

Perfecto operis a nobis suscepti primo libro, auditores suauissimi, et iam maiori fere laboris Deo et nobis dedicati parte transacta, quam procul a terra nostra ratis processerit sentire incipimus. Dum enim e portu ea soluebatur et fidae stationis sinus oraeque primi litoris ante oculos erant, optima spe alebamur, et interdum in uicinam tellurem montesque propinquos nec dum euanescentes lumina reflectebamus, interdum in pelagus transmittendum spectantes, perinde quasi

\footnotetext{
${ }^{12}$ Vd. Aires Barbosa. Aratoris Cardinalis..., fol. iii vo; cf. Manso, op. cit., pp. 96-97.
} 
nobis sat firma atque instructa nauis esset, nec uela contrabere, nec remos inbibere curabamus. Mox aura sollicitante prouecti longius nec a tergo litus iam, nec a fronte portum conspicimus.

Certe nunc experti minas pelagi undique circumpositi, quid sibi illud Vergilii carmen uelit intellegimus: "Iam non amplius ulla occurrrit tellus, caelum undique et undique pontus", atque in alto turbatoque mari deprehensi nec retro ire sine dedecore, nec ultra tendere sine periculo possumus; adeoque fluctus adhuc emetiendi nobis occurrunt impediti ac difficiles (sunt enim uel emensis difficiliores) ut nunc demum nostrae temeritatis admoneamur, qui rate fragili tam uastum aequor tamque turbulentum intrauerimus. $^{13}$

"Concluído o primeiro livro da obra tomada a nosso cargo, amabilíssimos ouvintes, e quase terminada a maior parte do trabalho que a Deus e a vós dedicamos, começamos a dar-nos conta de para quão longe da terra avançou a nossa barca. $\mathrm{Na}$ verdade, enquanto ela zarpava do porto, e a enseada do fiel ancoradouro e as praias da beira-mar estavam diante dos nossos olhos, uma enorme expetativa nos alimentava, e umas vezes voltávamo-nos para trás olhando a terra vizinha e os montes próximos que ainda não haviam desaparecido da vista; outras vezes, contemplando o pélago que tínhamos de transpor, como se tivéssemos uma nau devidamente robusta e construída, não curávamos de recolher as velas nem de abrandar os remos. E em breve, impelidos para mais longe por uma forte brisa,já não enxergamos nem praia nas costas, nem porto à nossa frente.

Agora, ao experimentar as ameaças do pélago que nos cerca por todo o lado, é que entendemos o sentido daquele verso de Virgílio "Já não mais se avistava terra alguma, apenas céu de todo o lado, de todo o lado a extensão do mar”, e, surpreendidos no mar profundo e conturbado, não podemos voltar atrás sem desonra, nem prosseguir mais além sem perigo; e as vagas ainda por atravessar surgem-nos de tal modo intransponíveis e com tal dificuldade (são na verdade até mais difíceis do que aquelas já ultrapassadas), que só neste momento nos apercebemos da nossa temeridade, agora que entrámos neste tão vasto e tão turbulento espaço marítimo.”

Para lá das dificuldades objetivas e científicas inerentes à feitura de um livro - à fetura, isto é, à "gestação", ou "criação", como diria Lopo Serrão: "Ad Lectorem"14 - , sobretudo de uma obra de caráter eminentemente filológico como é esta do humanista Aires Barbosa, com todo o trabalho de pesquisa e análise, de heurística e hermenêutica que ele teve de resolver, acrescem os obstáculos e resistência dos seus opositores, invejosos e inimigos, que são, quase sempre, os amigos da mesma arte, e que residiam dentro da própria

${ }^{13}$ Vd. Aires Barbosa. Aratoris Cardinalis..., fol. cii - cii vo.

${ }^{14}$ Sebastião Tavares de Pinho. Lopo Serrão e o poema Da Velbice. Estudo introdutório, texto latino e aparato crítico, tradução e notas. Coimbra: Centro de Estudos Clássicos e Humanísticos da Universidade de Coimbra, 1987, p. 277. 
Universidade de Salamanca, como ele denunciou por escrito em um dos seus epigramas ${ }^{15}$.

Com efeito, desde que o humanista português integrou o corpo docente salmantino, empenhou-se no movimento de reforma pedagógica e científica na área das humanidades, com a defesa do estudo das línguas de acesso direto às bases da cultura universitária, a começar pela língua grega, praticamente desconhecida, e pelo incremento e maior rigor no domínio do latim, a língua de uso oficial mas que havia atingido níveis de degradação escandalosa. Acrescia, ainda, a necessidade de purificar os textos dos autores programáticos, nas várias disciplinas de todas as faculdades, mediante a aplicação de uma rigorosa crítica textual, para a purgação de toda a espécie de excrescências acumuladas ao longo dos séculos.

Esta luta de Aires Barbosa, de resto já antes iniciada por outros humanistas como António de Nebrija, causou a maior reação dos mestres conservadores do Estudo salmantino, sobretudo juristas, médicos, filósofos e teólogos. Desse combate contra "a barbárie universitária" - a expressão é dos dois humanistas dá conta o Mestre Grego em muitos dos seus epigramas latinos de cariz satírico. E é a tais opositores que ele agora se refere, usando da mesma linguagem alegórica da viagem marítima:

Verum enim uero haec quae paulo ante dixi nequaquam me tantum mouent, ceteraque quibus in alto nautae terrentur - crebri turbines, atrum caelum, globi fumigantes, latentes scopuli - quantum Scyllaei canes et maleficum genus piratarum, qui hoc ipsum quod nauigamus mare, latrociniis ex occulto inuadentes grauius infestant. Hi uel bonis nos spoliare nostris puppemque infirmam pessumdare, uel moram moliri nostraeque nauigationis cursum interpellare conabuntur. ${ }^{16}$

"Mas, em boa verdade, o que me inquieta não são, de modo algum, tanto estes perigos de que há pouco falei e os restantes com que os marinheiros são aterrorizados no alto mar - os sucessivos turbilhões, um céu de negro aterrador, os rolos de vagas fumegantes, os rochedos latentes -, como sobretudo os cães de Cila e a maléfica raça dos piratas, que, atacando às ocultas este mesmo mar que navegamos, o infestam com bem pesados latrocínios. Estes hão de tentar ou espoliar-nos de nossos bens e meter a fundo a nossa embarcação, ou tramar a demora e interromper a rota da nossa navegação."

Barbosa procura rebater todos os ataques dos seus adversários, "mas", diz ele, "os violentos corsários, repelidos dum lado, irão sacudir a nossa embarcação

${ }^{15} \mathrm{Vd}$. Aires Barbosa. Arii Barvosae eiusdem Antimoria et nonnulla epigrammata, fol. XXVIIXXVIII; Cf. Sebastião Tavares de Pinho. Humanismo em Portugal, Estudos I. Lisboa: Imprensa Nacional - Casa da Moeda, 2006, pp. 107-108

${ }^{16} \mathrm{Vd}$. Aires Barbosa. Aratoris Cardinalis..., fol. cii vo. 
noutra parte e tentarão atacá-la com trágulas ou seguramente retê-la com o lançamento de arpéus, pois é provavelmente com dardos deste tipo que eles vão aparecer-nos pela frente": Sed uiolenti praedones hinc repulsi alia parte ratem nostram quatient, et uel tragulis eam tentabunt infestare, uel certe immissis harpagonibus retinere. Nam huiusmodi telis nobis forsan obuiabunt. ${ }^{17}$

Porém o derradeiro e mais violento ataque contra o nosso humanista é movido pelos teólogos, que, não tendo argumentos científicos contra a sua obra filológica, em que ele mostra dominar as próprias questões de matéria teológica que a Historia Apostolica de Arátor naturalmente lhe suscita, entrando assim na seara dos mestres da ciência sacra, lançam-lhe uma ridícula condenação que ele rejeita e expõe desta maneira, sempre apoiado na metáfora náutica:

Sed hinc reiecti oppugnatores mei se hactenus missilibus et leuibus iaculis mecum egisse contendent. At nunc tormento aliquo fulmineo et proeliari machina nostrae rati suppressionem ac naufragium minabuntur. Itaque dicent: "Quid homini connubii uinculis alligato cum theologia?" Et quasi diuinae litterae in cucullato habitu aut in sacerdotis pallio tantum sedeant, "cur» inquient «res sacras profanae manus contrectant et polluunt? Non enim decet uos qui mariti estis, sed sacris initiatos diuina scientia.»

"Mas os meus agressores, daqui repelidos, afirmarão que até este momento lidaram comigo com armas de arremesso e dardos ligeiros. Agora, porém, ameaçarão o afundamento e naufrágio da nossa barca com o recurso a algum arremesso de fogo e máquina de guerra. E, assim, dirão: «Que tem a ver com a Teologia um homem amarrado às cadeias do matrimónio?» E, como se as divinas letras assentassem apenas num hábito com capuz ou numa capa de sacerdote, dirão: «Por que razão mãos profanas tocam e mancham as coisas sagradas? A ciência divina não é própria de vós que sois maridos, mas dos iniciados nas coisas sacras."

E Aires Barbosa acrescenta com ironia, voltando à metáfora náutica dos piratas e salteadores do mar, insinuando que ele, na sua humilde ciência teológica, talvez mereça melhor do que eles ornar a sua cabeça com as insígnias doutorais dessa prestigiada faculdade:

Vtinam (ut ad uos redeam, auditores amantissimi) piratae uel potius canes illi non tam falsum quam uerum mibi crimen oblatrarent, et ego non imus sed summus theologus essem, ut possem capiti meo dominae coronam iure circumponere. ${ }^{18}$

\footnotetext{
${ }^{17}$ Vd. Aires Barbosa. Aratoris Cardinalis..., fol. cii vo.
}

${ }^{18}$ Vd. Aires Barbosa. Aratoris Cardinalis..., fol. ciii. 
"Quem dera (para me dirigir de novo a vós, amabilíssimos ouvintes) que os piratas, ou antes, aqueles cães ladrassem contra mim acusando-me não tanto de um crime falso mas verdadeiro, e que eu fosse não um ínfimo mas um supremo perito de teologia, para poder com razão circundar a minha cabeça com a coroa dessa Senhora."

E o humanista acaba por rebater e votar ao desprezo os adversários e termina o prefácio do Livro II com uma nova invocação a Deus e à Virgem, para que o inspirem e ajudem a levar esta segunda parte da empresa literária até ao fim, repetindo mais uma vez a metáfora náutica ${ }^{19}$ :

Et nunc, omnipotens, quamuis iuuenilia tractem, precor inspires uento mea uela secundo!

Tu quoque, Virgo Parens, da, clementissima Virgo, ut sit grata uiris mea commentatio doctis.

"E agora, Deus omnipotente, ainda que eu trate de juvenílias, dignai-Vos enfunar as minhas velas com vento favorável! E também Vós, Ó Virgem Mãe, concedei-me, clementíssima Virgem, Que o meu comentário seja agradável aos homens doutos.”

Finalmente, terminado o comentário do Livro II, num total de 1.250 versos distribuídos por dezanove secções sobre os feitos do apóstolo Paulo, Aires Barbosa dá por finda a sua viagem literária com a chegada ao porto do seu destino, e assim conclui esta edição comentada da Historia Apostolica do poeta cardeal Arátor:

Sed quoniam iam in portum caelesti flante spiritu peruecti sumus, uela complicemus, nauem subducamus eique gratias agamus cuius munere nostrae commentationis munera uobis impartiri, auditores suauissimi, datum est. Erimus autem gratiores magisque accepti a Deo clementissimo beneficii memores, si nobis in mentem crebro uenerit recordatione assidua recolentibus, quantum fuerit tot scopulos, tot maria, tot turbines euasisse, mediosque uiam per hostes tenuisse. Ad hunc autem optatae quietis sinum licuisset nunquam nobis uenire sine Dei fauore, qui dixit: "Sine me nibil potestis facere ${ }^{20}$

Proderit sane repetere memoria casus uarios et pericula et laborem, quae tam et si in experiendo dura fuerunt tamen in recordando ei iucunda sunt, qui extra aleam discriminis positus secure in portu quiescit. ${ }^{21}$

\footnotetext{
${ }^{19} \mathrm{Vd}$. Aires Barbosa. Aratoris Cardinalis..., fol. ciiii vo.

${ }^{20}$ Vd. Aires Barbosa. Aratoris Cardinalis..., fol. cxlviii vo - cxlviiii, mihi fol. cxlviiii vo - cl.

${ }^{21}$ Vd. Aires Barbosa. Aratoris Cardinalis..., fol. cxlviiii, mihi fol. cl.
} 
"Mas, uma vez que já fomos conduzidos ao porto pelo impulso do sopro divino, enrolemos as velas, ponhamos a nau a seco e demos graças Àquele por cujo benefício vos foi concedido, amabilíssimos ouvintes, partilhar dos benefícios do nosso comentário. E com a recordação dessa graça, seremos mais gratos e mais aceites a Deus clementíssimo, se nos vier à mente, em assídua relembrança, quanto nos custou escapar-nos a tantos escolhos, a tantos mares, a tantos turbilhões, e manter a rota pelo meio dos inimigos. E nunca nos teria sido possível chegar a esta baía da almejada tranquilidade sem o favor de Deus, que disse "Sem mim nada podeis fazer.

"De grande proveito será certamente trazer à memória as desvairadas desgraças e perigos e trabalhos que, por muito duros que tenham sido na sua experiência, se tornam todavia agradáveis na recordação de quem, posto já fora do risco de perigo, goza, em segurança, o porto da tranquilidade.”

Em harmonia com o metaforismo náutico que percorre esta obra de Aires Barbosa, e a confirmá-lo, o humanista fez publicar à cabeça da sua edição o seguinte epigrama dedicado ao leitor comum e dominado pela mesma metáfora, da autoria de um seu aluno chamado Teófilo, que relembra a origem portuguesa do seu mestre e a sua função de professor que lhe valera o apelido de "Mestre Grego", e esta sua aventura de marinheiro-escritor ${ }^{22}$ :

\section{Theophilvs AD Lectorem de Nova COMMENTATIONE}

Arit LVSITANi PRAECEPTORIS SVI.

Primus in undoso quisquis dare uela profundo est

Vsus, et ignotas sollicitare uias,

Naturam ingenio uicit. Namque astra secutus

Subdidit imperio caerula cuncta suo;

Terruit haud illum Caelum undique et undique pontus,

Atque suo aspectu terra relicta procul.

Arduus haud illi decimae tumor obstitit undae

Haud breuia, et Syrtes, Cyaneaeue petrae.

Quin raperet solis patuit quod piscibus aequor.

Artis, an audendi, laus prior utra fuit?

Qui minus ecce ualet, cui Lusitania origo est,

Cui Graeco nomen Graecia culta dedit?

Publica demisit praeclara audacia nostri

Barbosae celebris doctiloquique uiri.

Deseruit terras, fructusque ingressus, Arator

Docte, tuos, fluctus et uada salsa domat.

Atrum occurrebat picea caligine caelum,

Horrebantque feri monstra profunda maris.

${ }^{22}$ Vd. Aires Barbosa. Aratoris Cardinalis..., fol. i. 
Omnia felici cursu peragrauit, et undas

Intactasque docet findere primus aquas.

Monstrat et ingenio quod nullus transiit aequor,

Id transire queat qua ratione puer.

Telos.

\section{TEÓfILO, AO LEITOR, ACERCA DO RECENTE COMENTÁRIO do seu mestre Aires Barbosa}

Quem quer que tenha ousado largar vela nas ondas

Do profundo e acossar seus ignotos caminhos

Venceu com seu engenho a natureza. Pois, ao seguir os astros,

Submeteu ao seu império todos os seres celestes;

Não o assustou aquele céu de todo o lado, aquele mar em toda a volta,

Nem a terra deixada ao longe e fora de sua vista.

Não lhe resistiu o alto mar inchado na sua décima onda,

Nem baixios, nem Sirtes, nem Rochedos Ciâneos.

Quem acaso se arrogaria o que só aos peixes o mar patenteou,

Ou quem primeiro teve a honra da arte de ousar uma e outra coisa?

Eis, foi quem menos poder tem, quem tem Lusitânia por origem,

Ao qual, como a um grego, a Grécia o seu nome concedeu!

Largou excelências públicas a audácia do nosso

Homem famoso e bem-falante Barbosa.

Saiu da terra e, entrando nas tuas vagas, ó douto

Arátor, as vagas e as salsas ondas domina.

Vinha contra ele o céu escurecido de negra caligem;

Erguiam-se, pavorosos, os profundos monstros do fero mar.

Tudo ele atravessou em seu fecundo percurso; e é quem

Primeiro ensina a rasgar as vagas e ondas intactas.

E mostra com seu talento que nenhum oceano o superou,

$\mathrm{E}$ com que processo o pode superar uma criança.

Este recurso ao espaço e à vida da navegação como termo comparativo e simbólico quer da existência humana, da experiência amorosa, da atividade política e sobretudo da criação literária, fazendo do ser humano, do enamorado, do Estado ou de quem o governa, e em particular do criador literário, navegantes de outros tantos mares em que lutam pelo seu destino, este recurso - repito representa, como vimos, uma herança antiga de origem greco-latina e manteve uma forte e perene tradição nas sucessivas épocas e literaturas, designadamente na Idade Média e no Renascimento. A prová-lo, podemos lembrar Dante nos séculos XIII-XIV, que recorre à bela imagem da nau do engenho literário, por exemplo, no início do segundo livro do Convívio e no começo tanto do 
Purgatório (I, 1 sqq.), como do Paraíso (II, 1-15) da Divina Comédia ${ }^{23}$; e, já no séc. XVI, Ariosto, que usa do mesmo recurso no canto 46 de Orlando Furioso ${ }^{24}$, bem como o teorizador Marco Jerónimo Vida na sua Arte Poética, I, 62-65 e 80-81 $1^{25}$.

No domínio da área política e social ficou famosa a grande alegoria do estraburguês Sebastião Brant, A Nau dos Loucos [Das Narrenschiff(1494); trad. latina Stultifera Nauis (1497), por Jacob Locher), em que o autor satiriza as fraquezas e desvarios da sociedade do seu tempo. E no campo da lírica amorosa, entre muitos exemplos citarei o curioso exemplo quinhentista do humanista flamengo Everaerst, mais conhecido por João Segundo, que num poema dos seus Basia (I, 9-12), exprime a sua paixão pela amada Júlia no contexto de uma travessia náutica pela região dos mortos da tradição clássica ${ }^{26}$.

Quanto à presença desta metáfora náutica em autores portugueses, tanto em língua latina como em português, podemos citar a mero título de exemplo, o Livro da Virtuosa Benfeitoria da coautoria do Infante D. Pedro e frei João Verba (primeira metade do séc. $\mathrm{XV}$ ), em que o(s) autor(es), à beira de terminar a sua composição (no início do "vio e postumeyro livro"), assim se exprime(m): [...] "Nom sento folgança em o que screvi senom emquanto sguardo com pequeno prazer a deleytosa praya daqueste mar grande, que a outros mais sabedores he pequeno ryo. E com sperança de pousar a nave do meu fraco entender que, per batimentos de contrayras ondas, jaz muito fraca em grande cansaço, farey termho em aqueste livro e lançarey ancora sobre o porto, com entençom de tarde ou nunca tornar a logar em que me feyram taaes tempestades." D. Pedro, um escritor arrependido!

Recordemos, também, o italiano ao serviço do Estado e do Humanismo português, Cataldo Parísio Sículo, que inicia o seu poema latino sobre a conquista de Arzila (Arcitinge) com estes versos dedicados a D. João II, antes de $1495^{27}$ :

${ }^{23}$ Cit. por Ernest Robert Curtius. Literatura Européia e Idade Média Latina. Trad. Teodoro Cabral Rónai. São Paulo: Editora Hucitec / Editora da Universidade de São Paulo, 1996, pp. 177-181.

${ }^{24} \mathrm{Cf}$. ibidem.

${ }^{25}$ Cf. Marco Jerónimo Vida. Arte Poética. Introdução, tradução e notas de Arnaldo M. Espírito Santo. Lisboa: Centro de Estudos Clássicos da Universidade de Lisboa, 1990, pp. 144145.

${ }^{26}$ Cf. José Ignacio Ciruelo Borge. Ioannis Secundi, Basia, I, 9-12. Nota para la historiografía literaria de la metáfora náutica. Humanismo y Pervivencia del Mundo Clásico, I. 1. Cádiz: Instituto de Estudios Turolenses / Servicio de Publicaciones de la Universidad de Cádiz, 1993, pp. 323327.

${ }^{27}$ Tradução de Américo da Costa Ramalho. Latim Renascentista em Portugal (Antologia). Coimbra: Centro de Estudos Clássicos e Humanísticos da Universidade de Coimbra, 1985, pp. 64-65. 
Magne deum cultor placido me conspice uultu

Et timidae aspira felici flamine cymbae!

"Grande cultor dos deuses, olha-me com rosto sereno

E com um sopro ameno favorece o meu tímido barco!”

André de Resende termina o seu poema de encómio à cidade e à Universidade de Lovaina, publicado em Bolonha em 1529, incitando a juventude lovaniense a remar a fundo por sobre os mares contra a barbárie dos inimigos da cultura ${ }^{28}$.

D. Jerónimo Osório, no tratado acerca da glória (De gloria libri $V$ ) publicado em Coimbra em 1549, por várias vezes recorre ao comparante da viagem náutica, para exprimir ou o processo da elaboração literária e da discussão filosófica, ou a ambição da vida humana, instável e efémera como um barco à deriva das vagas, ou ainda a conquista da própria glória ${ }^{29}$.

José de Anchieta, ao celebrar, no Brasil, os feitos gloriosos do terceiro governador do Brasil, consignados na sua epopeia De Gestis Mendi de Saa, publicada em Coimbra em 1563, assim cantava ${ }^{30}$ :

[...] Vellem si stringere singula uersu quae facit, ardenti Christi inflammatus amore, immensus foret iste labor, pelagique profundo magna prius paruam mersaret sarcina cymbam, quam posset tuti contingere litora portus, verba prius certis pedibus cogenda deessent, quam memorandarum latissima copia rerum.

Se eu quisesse reduzir a verso quantos feitos Ele praticou, inflamado do ardente amor de Cristo, seria tal tarefa desmedida, e às profundezas do pélago, a enorme carga faria mergulhar o meu pequenino batel, antes que ele pudesse atingir a praia do porto seguro.

E mais faltariam palavras a condensar no rigor do ritmo Do que larguíssima cópia de gestas a celebrar.

\footnotetext{
${ }^{28} \mathrm{Cf}$. André de Resende. Encomium urbis et academiae Lovaniensis. Bolonha, 1529, vv. 171173.

${ }^{29}$ Cf. João Nunes Torrão. D. Jerónimo Osório e o tratado De Gloria, Tomo II. Edição crítica. Coimbra: Faculdade de Letras, 1991, pp. 177, 180-181 e 202.

${ }^{30}$ Vd. José de Anchieta. De gestis Mendi de Saa. Poema Épico. Obras Completas - 10 Volume. Introdução, versão e notas do Pe. Armando Cardoso, S.J., São Paulo: Edições Loyola, 1986, p. 150, vv.1334-1340.
} 
Damião de Góis, em 1566, ao assumir o encargo de escrever a Coroniqua do Felicíssimo Rey Dom Manuel, faz uso da metáfora náutica para exprimir a decisão de deixar outros trabalhos e dar prioridade a essa empresa: "E pois tudo o tratado nesta parte, é quási nada em comparação do que deve ser, voltarei daqui a vela, pera poer a proa nesta." ${ }^{31}$

Camões não podia, evidentemente, deixar de incluir no seu vastíssimo repertório de recursos ao metaforismo clássico, esta imagem da navegação pelos mares da criação literária. $\mathrm{E}$, assim, ao narrar a visita do Catual a bordo da nau capitaina e quando principiava a descrever e a explicar ao visitante, pela boca de Paulo da Gama, o significado das figuras pintadas nas bandeiras, interrompe a descrição da primeira figura - a "de um velho branco, aspeito soberano" que tinha "um ramo por insígnia na dereita" - e faz a seguinte invocação para assinalar a importância deste episódio ${ }^{32}$ :

"Um ramo na mão tinha ... Mas, ó cego,

$\mathrm{Eu}$, que cometo, insano e temerário,

Sem vós, Ninfas do Tejo e do Mondego,

Por caminho tão árduo, longo e vário!

Vosso favor invoco, que navego

Por alto mar, com vento tão contrário,

Que, se não me ajudais, hei grande medo

Que o meu fraco batel se alague cedo.

E não deixa de ser particularmente expressivo o uso camoniano da mesma metáfora náutica no soneto Busque amor novas artes, novo engenho, em que o poeta resume o desconcerto e a desesperança do enamorado nestas palavras de um simples verso: "Andando em bravo mar perdido o lenho".

A mistura da invocação com a metáfora náutica é muito frequente em textos épicos ou de feição similar, como acontece também com o poema acerca da velhice (De senectute) do médico Lopo Serrão, publicado sete anos depois d'Os Lusíadas e num modelo de composição que ostenta amplitude e estrutura de epopeia. Dividido em catorze cantos, num total de cerca de 8000 versos elegíacos, assim começa a sua invocação inicial associada à metáfora da viagem marítima ${ }^{33}$ :

\footnotetext{
Alma Dei Genetrix, supplex tua numina posco, nauiget ut felix haec mea cumba mari.

Tu uero, aligeri regina puerpera coetus, uela senectutis flamine tende tuo.
}

${ }^{31}$ Vd. Damião de Góis. Crónica do Felicissimo Rei Dom Manuel. Nova edição conforme a primeira de 1566. Coimbra: Universidade, 1949, p. 1.

${ }^{32}$ Vd. Luís de Camões. Os Lusíadas. Lisboa: António Gonçalves, 1572, VII, 78.

${ }^{33}$ Vd. Sebastião Tavares de Pinho. Lopo Serrão e o poema Da Velhice, I, 1-7, p. 293. 
Doce Mãe de Deus, suplicante imploro o teu poder,

Para que esta minha barca seja feliz na travessia do mar.

Sê tu, mãe e rainha do coro alado,

A estender, com tua brisa, as velas da velhice.

O mesmo poeta apresenta ao longo do poema vários exemplos da metáfora da nau ou do pélago da vida humana, designadamente em I, 71, V, 295-296; VI, 255-259; e VII, 73-80. E o seu fecho contém o seguinte remate a confirmar a aplicação da mesma metáfora à composição e escrita de todo o poema ${ }^{34}$ :

Cogere uela licet, dum nauis litora pulsat, et licet optatas calce subire domos.

Hoc opus absoluit felici carmine Musa, parta quies ergo limina nostra beet.

É tempo de recolher as velas enquanto a barca bate na praia; É tempo de penetrar, ao fim da meta, nas apetecidas mansões.

Este poema, fechou-o a Musa com um canto auspicioso:

Que o repouso alcançado torne, pois, feliz a nossa morada.

Exemplos como estes podem encontrar-se em muitos outros autores do espaço da língua portuguesa, mas esta amostragem basta para verificar que se trata de um processo literário de frequente recurso e de efeito estético de forte expressividade, embora um tanto esquecido da crítica literária moderna. De longa tradição nas literaturas grega e latina, cujos povos sempre mantiveram grande convivência e dialética com a vida do mar, foi, por isso, um elemento da arte literária de geração natural e por assim dizer espontânea. $\mathrm{E}$ foi assim que o recebemos juntamente com as bases também greco-latinas da nossa cultura lusófona, plasmada numa história também de nautas e navegadores e numa vocação marítima particularmente sensível às imagens do mar.

\footnotetext{
${ }^{34}$ Vd. ibidem, XIV,629-632, p. 738.
} 



\title{
A EDIÇÃo QUINHENTISTA DO COMENTÁRIO BARBOSIANO À Historla Apostolica de Arátor
}

\author{
José Henrique Rodrigues Manso \\ Universidade da Beira Interior
}

Este artigo é baseado na comunicação que proferimos aquando do colóquio Aires Barbosa na Cosmópolis Renascentista, realizado em 15 de novembro de 2011 em Coimbra, cidade onde, há 476 anos, Aires Barbosa editou a sua última obra, a Antimoria. Gostaríamos, pois, de agradecer, desde já, aos três centros ( $\mathrm{CECH}, \mathrm{CEC}$ e APENEL) que uniram esforços para realizar esta iniciativa sobre um autor a quem temos dedicado muito do nosso tempo e estudo. $\mathrm{O}$ presente artigo foca a obra-prima do humanista aveirense, o Comentário à "Historia apostolica" de Arátor, no que concerne a aspetos editoriais, que não podem ser dissociados dos avanços e contingências da imprensa nos inícios de Quinhentos.

Comecemos por traçar uma brevíssima biografia de Aires Barbosa. Sobrinho do humanista Martim de Figueiredo, Barbosa nasceu por volta de 1470 em Esgueira, e foi em solo luso que fez as primeiras letras. Embora a crítica seja unânime em afirmar que, por volta de 1482, Barbosa rumou a Salamanca, onde hauriu o saber de grandes mestres como António de Nebrija ou Lúcio Marineo Sículo, nenhum texto ou documento confirma a sua presença na cidade do Tormes antes de 1495. Sabemos, no entanto, que, por volta de 1490, seguiu para Florença, tendo sido aluno de Ângelo Policiano, o mestre de quem se dirá orgulhosamente discípulo ao longo de toda a vida, e convivido com personalidades de renome, como João de Médicis, Hermolao Barbaro ou Pico della Mirandola. Em 1495, é convidado a integrar o corpo docente da Universidade de Salamanca, e a cátedra de Grego arranca nesse ano com Aires Barbosa. Foi ele o primeiro a ensinar a língua helénica a nível universitário em toda a Península Ibérica, o que lhe valeu o honroso epíteto de Mestre Grego. Em 1503, Aires Barbosa acrescentou ao Grego a Retórica, que abandonaria quando, em 1509, conseguiu a almejada cátedra de Gramática, mais prestigiada e com um salário muito superior. Jubilandose em 1523, Barbosa regressou a Portugal, onde, a pedido de D. João III, se torna mestre do infante cardeal D. Afonso. Faleceu na sua terra natal, Esgueira, a 20 de janeiro de $1540^{1}$.

\footnotetext{
${ }^{1}$ Sobre a vida de Aires Barbosa, vejam-se, entre outros, Francisco Ferreira Neves, «Vida e testamento de Aires Barbosa», Arquivo do distrito de Aveiro, 14 (Aveiro, 1948), p. 42-64; e José Henrique Manso, Comentário de Aires Barbosa ao segundo livro da Historia apostolica de Arátor, Lisboa, FCG/FCT, 2011, p. 28-42.
} 
Centremo-nos agora na obra que o humanista editou em Salamanca no ano de 1516 para inferirmos, a partir da análise dos originais, aspetos importantes da tipografia salmantina de então. No âmbito da regência do Latim (Retórica e Gramática), entre 1511 e 1517, Barbosa publicou na cidade do Tormes obras de caráter didático, destinadas a esclarecer os seus discípulos acerca das matérias lecionadas, sobretudo de índole gramatical: quatro opúsculos, um sobre verbos impessoais, outro sobre métrica latina, um terceiro sobre ortografia e, finalmente, um trabalho sobre prosódia. A estes junta-se o extenso Comentário à "Historia apostolica" de Arátor (1516), com cerca de centena e meia de fólios, a obra-prima do humanista e que constitui por si só mais de metade da produção barbosiana. De regresso a Portugal, publicaria ainda, em 1536, um poema intitulado Antimoria, no qual ataca o célebre Encomium moriae, de Erasmo, projeto a que dedicou seis anos. Deixando de parte esta última publicação, por se distanciar no tempo e no espaço das restantes, centremo-nos nos livros que vieram a lume em Salamanca num espaço temporal de seis anos. Os títulos completos, tal como constam nos originais, são os seguintes:

1. Arii Barbosae Lusitani in verba M. Fabii. Quid? quod E' reliqua. Relectio de Verbis Obliquis. [Cólofon:] Impressum Salmanticae Idibus Iuniis anno a genesi liberatoris nostri \& salutiferi Iesu. M.D.Xi

2. Arii Barbosae Lusitani Relectio, cui Titulus Epometria. [Cólofon:] Impressum Salmanticae, v. nonas Julij. M.D.Xv

3. ARATORIS CARDINALIS HISTORIA APOSTOLICA CVM/ Cõmentariis Arii Barbosae Lusitani. [Cólofon:] Impressum Salmanticae in aedibus Ioannis de Porris Mense Aprili. M.D.XVI.

4. Arii barbosae lusitani relectio: cui titulus prosodia; Arii Barbosae Lusitani relectio: cui titulus orthographia; Eiusdem Arii B. L. Nonnulla Epigrãmata. [Cólofon:] Impressum Salmanticae: Mense Decembri. Anno. M.D.XVII

Como se pode verificar, estas publicações, com exceção da terceira, não referem a tipografia, limitando-se a indicar o local: impressum Salmanticae. Esta lacuna tem uma explicação contextual, relativa à história da imprensa. Esta era uma realidade bastante recente em Espanha à data das edições barbosianas efetuadas em Salamanca, dado que a primeira oficina tipográfica surgiu apenas em 1474 em Valência. Só cinco anos depois é que a tipografia aparece em Salamanca, pela mão de António de Nebrija, que via na arte tipográfica um meio eficaz para expandir o seu saber e prestígio. Todavia, até as famosíssimas Introductiones Latinae (1481, 1482, 1485 e 1492) e a Gramatica Castellana (1492) omitem a identidade do tipógrafo. O anonimato dos primeiros tipógrafos salmantinos tem, segundo Cuesta Gutiérrez, a seguinte explicação: 
Sabiendo el concepto que como clase social tenía la artesanía, Nebrija, como catedrático de la Universidad, no podría estampar su nombre en este trabajo manual, incompatible con su cargo. ${ }^{2}$

De facto, só em 1496 aparece o nome do primeiro mestre tipógrafo num livro impresso em Salamanca, Leonardo Hutz, também conhecido como Leonardo, o Alemão. E é apenas em 1505 que se passam a conhecer nomes de tipógrafos espanhóis, pertencendo a Pedro de Pascua o lugar cimeiro, que naquela data deu à estampa o Quaderno de las leyes y nuevas decisiones sobre las dudas de derecho que solian y suelen ocurrir en estos Reynos ${ }^{3}$. $\mathrm{O}$ que verificamos, pois, confrontando estes dados com os que constam nas edições barbosianas, é que no primeiro quartel de Quinhentos há vários casos em que o tipógrafo ainda permanece no anonimato. Todavia, o $\mathrm{Co}_{0}$ mentário à "Historia apostolica" escapa a este fenómeno: terá o tipógrafo João de Porres querido associar o seu nome e o prestígio da sua casa a uma obra de inquestionável valor?

Se os opúsculos de Barbosa foram também impressos na tipografia de João de Porres, tal como o Comentário à "Historia apostolica", é algo que não podemos afirmar, mas admitimos como provável que tenha sido este o tipógrafo a imprimir todos os trabalhos atrás referidos, com exceção talvez do primeiro. Esta suspeição é reforçada por alguns factos. O Comentário à "Historia apostolica" é a consubstanciação das lições que o mestre português ministrou em 1513, conforme se pode ler no início do prefácio ao primeiro livro do Comentário (fl. ii), mas a verdade é que a obra só é publicada três anos mais tarde. Entretanto, vem a lume em 1515 a Epometria, um tratado sobre métrica latina que poderá ter sido uma resposta às dificuldades sentidas pelos seus discípulos na análise métrica dos hexâmetros dactílicos que compõem a Historia apostolica de Arátor. E apenas um ano depois da publicação do Comentário, Barbosa edita a sua última publicação em solo castelhano, que engloba o De Prosodia e o De Orthographia. Assim sendo, acreditamos que as publicações de 1515, 1516 e 1517 tenham sido impressas na mesma tipografia, explicitamente referenciada no cólofon do Comentário à "Historia apostolica": in aedibus Ioannis de Porris.

Além do local de edição, destacamos ainda o pormenor da datação das obras. O Comentário à "Historia apostolica" e o conjunto De Prosodial De Orthographia registam o ano e o mês: Mense Aprili. M.D.XVI e Mense Decembri. Anno. M.D.XVII, respetivamente. O De Verbis obliquis e a Epometria vão ao pormenor de apresentar o dia exato em que as obras foram editadas, 13

\footnotetext{
${ }^{2}$ Luisa Cuesta Gutiérrez, La imprenta en Salamanca: Avance al estudio de la tipografia salmantina (1480-1944), Salamanca, Ed. Universidad de Salamanca, 1960, p. 11.

${ }^{3}$ Ibidem, p. 14 e 24.
} 
de junho e 3 de julho, respetivamente, em datação romana (Idibus Iuniis e $v$. nonas Julij).

Passemos a outro nível de análise, focando em exclusivo o Comentário à "Historia apostolica". Apresentamos desde já alguns pormenores editoriais, reproduzindo parte do primeiro e do último fólio da obra supracitada: ARATORIS CARDINALISHISTORIAAPOSTOLICA CVM
CÓmentarilsAriiBarbof lufitani:

\section{Exprivilegfo ptitugform \\ Nequis in Hifinania uentid antex cudat fine atifitifiu permiffu ne. IHeophilus ad Lectoré de rioua Cómeritatlotic Arij Lufitani Praceptoris fui.}

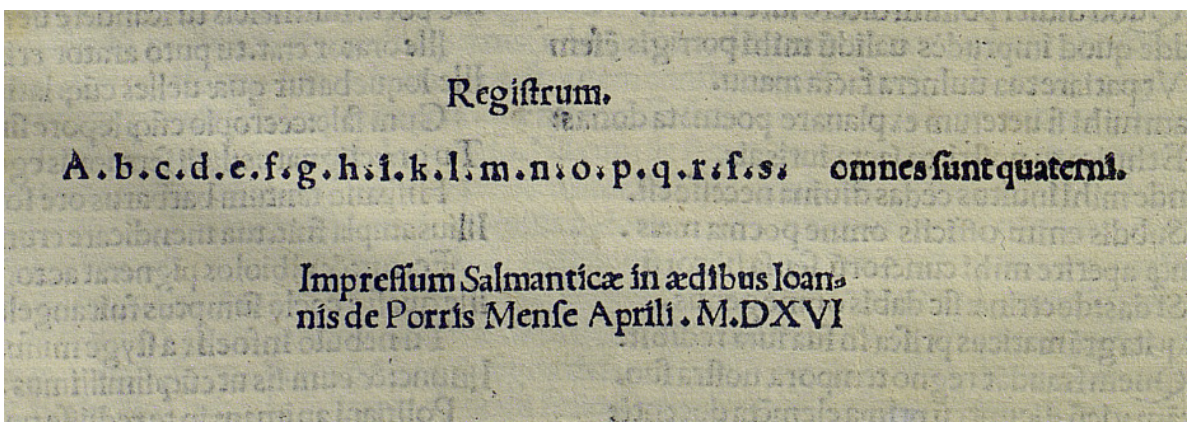

Tal como se pode ler na primeira imagem, o livro abre com um poema de Teófilo sobre este comentário. Trata-se de uma elegia de circunstância em onze dísticos elegíacos onde se glorifica a empresa barbosiana. No verso do primeiro fólio, Barbosa apresenta um interessante poema em quarenta e um dísticos elegíacos, onde louva Arátor e a sua Historia apostolica, rejeita os modelos dos heróis épicos clássicos (Aquiles e Ulisses), propondo como exemplares os heróis do poema aratoriano, Pedro e Paulo. Nos três fólios seguintes encontrase o prefácio ao primeiro livro de Arátor e uma brevíssima biobibliografia do poeta italiano, onde Barbosa segue de perto as informações de Aldo Manúcio que constam na primeira edição impressa da Historia apostolica, publicada em Veneza em 1502. Este facto é relevante, na medida em que Barbosa é sempre fiel à edição aldina, mesmo quando desconfia das opções do tipógrafo italiano, tal como acontece, por exemplo, na ordem por que transcreve os versos 19 e 20 da secção XV (fl. cxxxvii):

\section{Auctori certare fuo.defcendit ab aftrís (Aucta dies latuít.caligantefogtenebra) Lux oculos claufura meos: \& abígne corufco}


Como é evidente, os dois últimos versos estão trocados, pois a ordem correta é Descendit ab astris / lux oculos clausura meos e et ab igne corusco / aucta dies latuit. $\mathrm{Na}$ verdade, todas as outras edições que conhecemos registam os versos por esta ordem e o próprio Barbosa segue esta sequência na explicação que faz dos mesmos, mais adiante. No entanto, pensamos que o humanista aveirense se terá apercebido desta incongruência da edição de Aldo Manúcio ao colocar o verso aucta dies [...] tenebrae (v. 20) entre parênteses.

Depois do prefácio ao primeiro livro da Historia apostolica e dos prolegómenos à vida e obra de Arátor, da lavra de Barbosa, começa o texto propriamente dito, realizando o humanista a transcrição e comentário da obra aratoriana. A prefaciar a própria Historia apostolica, Arátor incluiu as cartas a Floriano e ao papa Vigílio, respetivamente o corretor e o destinatário da obra, que Barbosa transcreve e comenta dos fólios iiii a xi. Segue-se depois, até ao fólio cii, a transcrição das vinte e cinco secções da primeira parte do poema épico, e o minucioso comentário do humanista acerca desses mil e setenta e seis versos, que constituem a gesta de S. Pedro, tendo Arátor parafraseado os Atos dos apóstolos até ao capítulo doze. O comentário ao segundo livro segue uma estrutura muito similar à do primeiro. Encontramos também um prefácio, muito semelhante ao do primeiro livro, no tom, no estilo e até nas ideias, que ocupa três fólios (cii-ciiii) e termina com um poema de oitenta e oito hexâmetros dactílicos (fólios ciiii e ciiii $\mathrm{v}^{\mathrm{o}}$ ), onde Barbosa dedica a sua obra a Deus e à Virgem. Segue-se a transcrição das dezanove secções do segundo livro da Historia apostolica, num total de mil duzentos e cinquenta versos e respetivo comentário (fólios ciiii $\mathrm{v}^{\mathrm{o}} \mathrm{a} \mathrm{cl}$ ).

No que diz respeito apenas à parte do comentário ao segundo livro, devemos salientar que Barbosa dedica o dobro dos fólios ao estudo do primeiro livro, ainda que este registe menor número de versos. Na verdade, os mil duzentos e cinquenta versos versos do segundo livro da Historia apostolica são comentados em quarenta e seis fólios, ao passo que os mil e setenta e seis versos do primeiro lhe merecem nada menos que noventa e quatro fólios. A obra finaliza com uma errata e um conjunto de cinco epigramas, onde Barbosa defende o mérito do Comentário e ataca aqueles que contra ele se vão insurgindo.

Do ponto de vista editorial, pensamos ter bastante interesse a errata suprareferida, que ocupa aproximadamente duas páginas (a quase totalidade do fólio cl e o início do cli). Numa primeira nota, salientamos que o comentador dedica noventa e uma linhas ao primeiro livro e apenas quatro ao segundo. O humanista apresenta uma lista de algumas correções a introduzir no texto (corrige), como se pode verificar no excerto: 


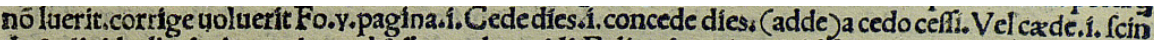

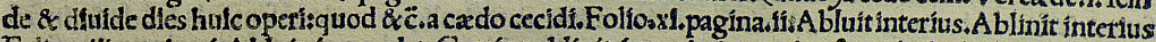

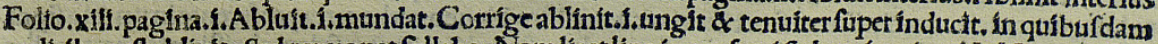
codicibus eft abliuit. Sed repugnat fyllaba. Nam licet lino in prefenti fit breuis prifor。 Vt Ver. thefaus rís relínes:tamen in praterito é lóga.líui. Hor.conditum liui.tuel leui. Eft ergolegendum A blinit:quía

No entanto, mais do que emendar, Aires Barbosa tem sobretudo a preocupação de adicionar novas informações aos comentários já produzidos. Veja-se, a título exemplificativo, a addenda que apresentamos de seguida, onde o humanista entende acrescentar às observações já feitas no fólio iiii o testemunho de mais cinco autores, dois cristãos, Agostinho e Hilário, e três clássicos, Plínio, Tito Lívio e Juvenal:

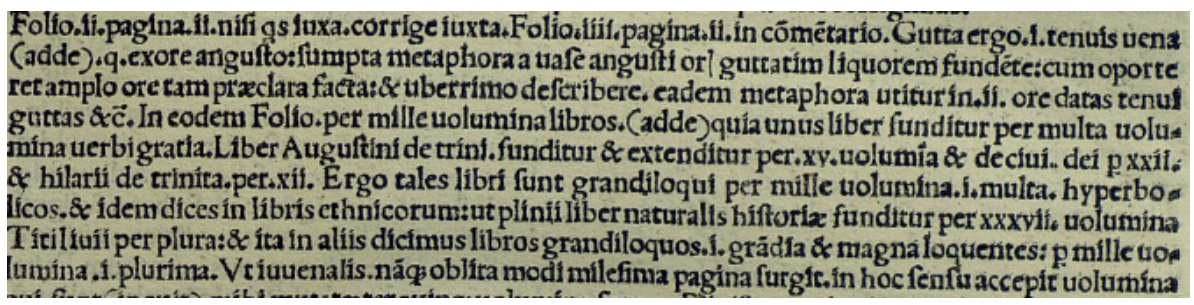

Antes deste trabalho "de última hora", chamemos-lhe assim, Aires Barbosa empreendeu uma profunda revisão ao Comentário, durante três anos, tal como o próprio revela logo na abertura do prefácio ao primeiro livro, esclarecendo que não o publicou mais cedo por se demorar na revisão e aperfeiçoamento do texto:

Petitis cotidie a me, auditores amantissimi, uel potius precibus omnibus oratis et obtestamini ut edam commentarios, quos ipse tumultuaria opera composui, nec per occupationes ex illo tempore uidere licuit, cum Aratorem poetam, qui acta apostolorum metrice scripsit, ab hinc triennium publice interpretabar.

Todos os dias me pedis, caríssimos ouvintes, ou antes, implorais com todas as preces e suplicais que publique os comentários que eu mesmo compus numa obra desorganizada e que, durante as minhas ocupações, nesse tempo, não me foi possível rever, quando eu comentava publicamente, há um triénio, o poeta Arátor, que escreveu em verso os Atos dos apóstolos. ${ }^{4}$

Aliás, o menor fôlego de Barbosa no De Prosodia é explicado nas páginas iniciais deste opúsculo pelo aturado labor dedicado à revisão das provas tipográficas do Comentário à "Historia apostolica", cuja correção lhe consumiu o tempo e as forças. É que, diz Barbosa, os erros pululavam não como serpentes, mas

\footnotetext{
${ }^{4}$ Aires Barbosa, Aratoris cardinalis Historia apostolica cum commentariis, fl. ii, tradução e sublinhado nossos.
} 
como se fossem sementes de papoilas:

Cupiebam ego in uestram et publicam omnium utilitatem commentarios in Aratorem meos formis istis uulgatis propagare [...]. Coepi etiam quosdam uitio excussorum pullulantes errores non tanquam excetrae, sed quasi papauerum capita stilo resecare. ${ }^{5}$

Assim, no final da Errata ao Comentário, e em jeito de conclusão, o humanista faz uma breve reflexão acerca do aperfeiçoamento do seu trabalho. Usando uma linguagem alegórica, Barbosa afirma que, tal como na ceifa caem sempre algumas espigas dos molhos cortados e na vindima se perdem irremediavelmente alguns bagos de uva, assim ele próprio, Aires Barbosa, qual ceifeiro ou vindimador, admite que algum erro lhe possa ter escapado nesse trabalho de revisão atenta da própria obra:

Haec, auditores suauissimi, in transitu lectionis tumultuariae emaculauimus. Sed adhuc (ut arbitror) multa oculos nostros omnium infirmissimos fugerunt. Vt enim [...] nullus est agricola tam gnauus cui non aliquid spicarum ex demessis manipulis in terram defluat, uel qui non aliquid praetereat quod post terga metentium pauperes, ut Ruth illa Moabitis, legere possint, [...] utque cautus uinitor [...] semper aliquid relinquit, quod post uindemiam ad incustoditas pueri uineas decurrentes sublegant, ita nullus est in libraria impressione tam callidus errorum undique pullulantium aut demessor aut uindemiator quin aliquid praetereat uel addendum, uel tollendum, uel mutandum, uel denique interpungendum dispungendumue.

No final desta lição tumultuária, dulcíssimos ouvintes, purificámos estes passos. Mas ainda, segundo julgo, muitos outros escaparam aos nossos olhos tão débeis de tudo. Tal como não há agricultor tão diligente a quem não caiam por terra algumas espigas dos molhos cortados, ou que não deixe algo que, atrás dos segadores, os pobres, como Rute, a famosa moabita $[R u t h 2,3]$, não possam recolher, e tal como o cauteloso vindimador deixa sempre alguma coisa que, depois da vindima, os meninos, precipitando-se para as vinhas sem guarda, vêm roubar, assim não existe também, na impressão de livros, nenhum ceifeiro ou vindimador tão conhecedor dos erros que pululam por todo o lado que não lhe escape algo para acrescentar, ou para suprimir, ou para mudar, ou, finalmente, para pontuar ou tirar pontuação. ${ }^{6}$

Esta reflexão, para além de literariamente valorizada por belas metáforas de sabor bíblico, revela ainda o preceito horaciano de que é necessário deixar amadurecer a obra para que ela possa ser apresentada no máximo esplendor.

\footnotetext{
${ }^{5}$ Aires Barbosa, De Prosodia, fl. ii.

${ }^{6}$ Aires Barbosa, Aratoris cardinalis Historia apostolica cum commentariis, $\mathrm{fl}$. cl vo e cli, tradução nossa.
} 
De facto, é esse o motivo que o humanista apresenta aos discípulos para só em 1516, passados três anos, atender às preces destes e publicar finalmente o Comentário:

Vua incocta peracerba est, deinde maturata dulcescit; ita sane longo tempore opus est, et, ut Horatius praecipit, nouennio, si uolumus ingenii nostri fructus [...] coctos esse.

A uva verde é muito azeda, mas depois de amadurecer torna-se doce; do mesmo modo, é realmente necessário um longo tempo, nove anos como recomenda Horácio [Arte Poética, vv. 388-389], se queremos que os frutos do nosso talento estejam maduros. ${ }^{7}$

Esta minuciosa revisão do texto subentende também a esperança de Aires Barbosa de que o Comentário granjearia sucesso editorial, o que não viria a acontecer. No entanto, alguns entraves parecem ter existido, pois o humanista, em diversos pontos, dissemina defesas enérgicas face aos críticos, que, entre outras coisas, o acusam de "meter foice em seara alheia”. É que, não sendo teólogo, Barbosa comenta e analisa detalhadamente a epopeia bíblica de Arátor, um enorme atrevimento na perspetiva dominante de uma universidade extremamente conservadora como era a de Salamanca. Essa defesa converte-se não raras vezes em insulto: cães de Cila e malfazeja raça de piratas $^{8}$, assim chama Barbosa aos seus detratores. No entender do humanista, as acusações dos críticos (ainda que eventuais ou apenas previsíveis) são injustificadas pela dedicação e saber que Barbosa colocou quer na produção, quer na revisão do texto, e por isso o humanista tem o seguinte desabafo:

Hoc factum meum fortassis haud reprehendendum uos oppido quam maligne inuertitis, et quia "mala sunt uicina bonis", quod rectum est intorquetis... Nam simplicem cultum uos appellatis fucum, et concessa ornamenta uocatis meretricum lenocinia.

Vós perverteis de forma completamente maldosa este meu trabalho, porventura irrepreensível, e, porque "as coisas boas são vizinhas das más"[Ov., Rem. Am., 323], retorceis o que é reto... Realmente, o culto singelo, vós o apelidais de disfarce, e aos ornamentos permitidos chamais adornos de meretrizes. ${ }^{9}$

Nem a dimensão da obra escapa ao humanista, que antecipa a acusação. No epigrama que encerra o Comentário à "Historia apostolica", Barbosa responde satiricamente a alguém que o acusava de a obra ser demasiado extensa: se

\footnotetext{
${ }^{7}$ Ibidem, fl. iiii, tradução nossa.

${ }^{8}$ Ibidem, fl. cii vo: Scyllaei canes et maleficum genum piratarum. Tradução nossa.

${ }^{9}$ Ibidem, fl. ciii, tradução nossa.
} 
eram muitos os comentários, lesse poucos, tornando, desta forma, a obra mais $\operatorname{curta}^{10}$. Com efeito, a discrepância entre os sonhos editoriais de Barbosa e a efetiva receção do Comentário revela que o mercado livreiro do primeiro quartel do século XVI poderia revelar frutos amargos para os autores da época. Transcrevemos um excerto de um epigrama onde o humanista aveirense se dirige à Academia salmanticense para ilustrar o quão grande deve ter sido a frustração de Aires Barbosa, tendo em conta o entusiasmo patente neste texto:

Cetera quae aedificas pereunt; uisetur in omni / gente, uel in populo uel regione meum.

Tudo o resto que edificas é perecível; a minha obra será contemplada / por todo o país, por todo o povo, por toda a região.... ${ }^{11}$

Voltando às questões gráficas, o caráter incipiente da imprensa salmantina no dealbar do século XVI e o preço do papel podem explicar algumas deficiências estéticas do Comentário. Comecemos pela compactação do texto. Para ilustrar este aspeto, apresentamos um fólio inteiro, o cxxxi:

${ }^{10}$ Ibidem, fl. cli vo: Ille putans mea commentaria longa, / pauca legat! Nostrum sic breuiabit opus.

${ }^{11} \mathrm{Ibidem}$, fl. cli, tradução nossa. Os versos transcritos são o 25 e o 26 do penúltimo dos cinco epigramas com que termina a obra e tem por título Academiam Salmanticensem alloquitur idem Arius B[arbosa] L[usitanus]. 


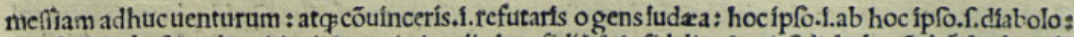

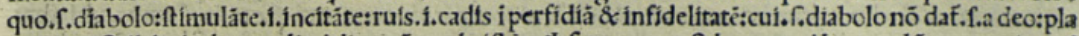
cere ore.f.tibl o ludax ut aligd dicat cōtra chriftü:qd.f. os mouet.f.damonad loquendü:terrore.i.teır

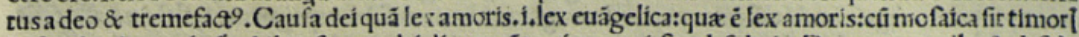
\& feruítutis:comítat: phibet.f. metu dei dicere côtrariasuoto.j.fuo defiderio. Dxmon.n.uellet \& defide

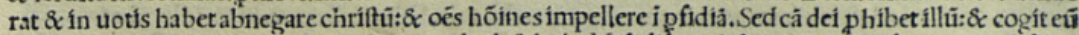

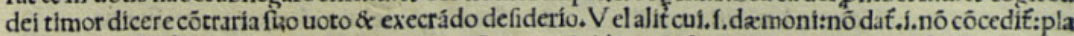

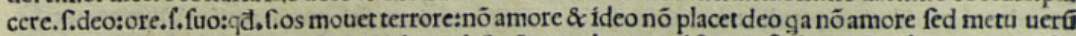

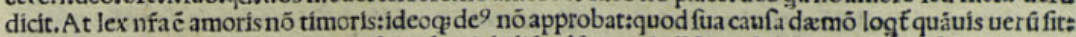
ga tremefact 9 illud pfert nô beniuolétix laudabili i pulfu mot ${ }^{9}$. (Hace cft)uera fides:quà.fuerã effenfí hoftes farētur. Túc.f.dæmonerepelléte a fe iudros illos:qua fpectacula.i.quos ludos plebi.f.ephefios

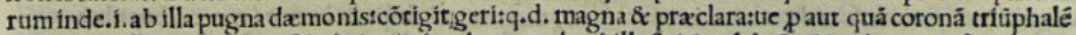

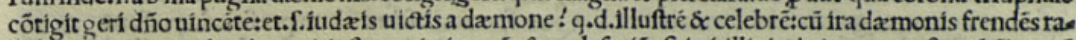
bido murmure:ira ditco bene.i.iufte noxia.í.nocés \& malefaciēs fuís.i.illis iudatis quos ut fuos hêbat:rú

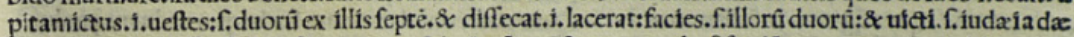
mone:fugitüt pícula.f.diaboli in eos irruétis: \& cóuertuit terga nuda. f. fugiêtes:patore pracipitil. 1. metu praxcipitáte. Dixit auitterga nuda:infpiciés habitūantiquoru militû:g terga nuda hẻbāt:pectora hoftiop pofita dútuxat armistegêtes. Vnde Saluftianus Catilina. Naminquit in fuga fpare falutê:cum arma qui

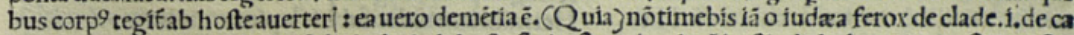
lamicare:quæ fic perís hofte.f:diabolo.1.ab hofte focio.f.tuo $: q$. d.cü hoftis diabolus cótra te furgat fos cíü tuû:nihîl eft quod tibinō fit tímendū. Cui.fíiudex idè diaboluséautor.i.impulfơr criminis.i.infide litatis: \& punitor.i.carnifex \&itortor:ne fit pulfus.f.dazmon acorpore damoniaci: te fudíce.1.te o itudaa

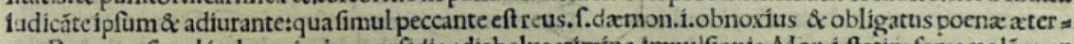
nx.Peccat.n.fimul fudxa crimine perfidia:diaboluscrimíne impulfionis.Mox.i.ftatim fama uolâs per urbem.f.cplsefiorum ubíg: fparfit.i.diuulgauir.f.hoc: \&cedere.j.edebat hoc eft uulgabat. f.famatut nos

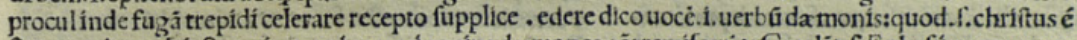
fumma uirtus déf. Copatris:cum In nomińne eius dxmones côtremifcerét: Gaudét.f. Ep phefií concurrere f. ad paulum:intrare in latices pios. f. baptifmi: \& lauare maculas uetuftas.f.peccatorifonte nouo.f.bas

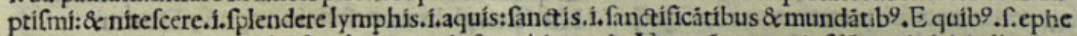
fiis baptizatis datur onnib 9 fimuluna xtas infons. i.innocés. Nam oés erant elufdéæatatis fpiritalis:quá uis atate corporea unus effet fenex:alter fuuenis:itaqzalius alio uel feniorucl iunior. (Aft alii.) multein= quir lucas ex ès qui fuerát curiofa fectati contulerût libros \& $<$ combufferât eos corã omnib 9 : $\&$ conputa tis precifs illorûinuenerút pecunía denarforum quinquaginta millium. (Aftalii.) f.necromantici $\alpha g e$ ne:hilaci:ponút fncendir.i.cremant: $\alpha$ ignemapponunt:librismagicis:ut mereantur aquas.f. baptifmi: \&́ uitantignes.f.gehénæ:ígnibus.1.comburédolibros magicos. Flăma.f.qua libri funt côbufti nimis ats dua fíalta \& pia fuit:cuius fulgor euolat fuper athera.i.coelum grata deo \& iuctida făma:\& fauill $x$. í cíneres librorü combuftorum tales periere.i. petieruit \& intraucrunt coclum:quia ad tribunal fummi def peruenerunt. Pofuere etiam precium libellis.f. combuftis :quinquaginta millita númo:um.f.denariorû: uel quía tanto preclo efient empti quốdam:uel quia fi uenditi fuifient táto precio.i.L.millibus denario rum uendi potuiffent quonian nocentes.í.malefici $\&$ necromáticímeruere abolere.i.purgare nefas.í. peccatum fuú:fic.f.numero quínquagenarioremiflionè denotante. Caufa huius figuræ efl hac. f. qua fequitur. Nam quínquagenarius numerustefertur ad poenitentiâ \& peccatorưremiffî̀né:unde $\delta \&$ quín quagefimus eft poeniteétix pfalınus qui incipif́: Miferere meldeus fecundü magnă nif́erícordiam triam. \& ce. \& quinquagefimus eft remiffionis annus:qui iubilaus appellatur:dietus a fobel .i.buccina ut ait Rab.Salo. Nam in leuitico pracepirdominus clangere tobel.1. buccina menfe feptimo: \& decima die menfis propiciationis tempus effe in uniuerfa terra l/raelitica. Hinc iubilaxus eft diaus hicannus quin̄̄gefimus :quodebitx relaxabátur pecunix. exules reuocabătur: feruidonabanturlibertate : ur tellusim munis eo anno haberetur ac quafeüg; fua fponte fruges tuliffectribulibus effent $\&$ hof pitibus commins nes. qua uilius ueniflent antiquis poffeffioribus redhibebätur. Nam quáto annus lubilaíułcinior infla bat tunto minoris bona aftimabätur:ac uiceinuerfa tả to maioris quâto longíus diftabat jubilaxus. ( $\mathrm{Nu}$

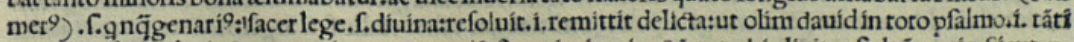
numeri:diluit.i. lauit \& purgauit p poenitentiá:fua crimina.i. petã.toto hic liceter fed tí pprie. Sicut.n。 a quot dicímus quotus:quod refeı tur ad quátitatem diícretamsita a tot dicimus tớus quod ad eádé quá tițtem reducif́. Sed quot ${ }^{\circ}$ eft in ufü:totus nó eft in ufu hac lignificatióe fed alia multứ diucrfa. Vtimur

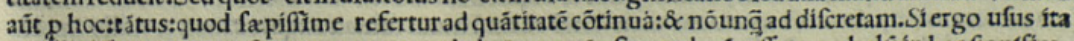
emolliuiffet totus a tot:ficut quotus a quot deductumrecte fonat:elegás effet uocabulti in hac fignificas tione. Caeterú defideram ${ }^{9}$ hic quáticatem $\delta$ menfumfyllabx. Videt.n. repugnare fi tot 9 a tot joducat: 
Esta mancha gráfica é a mais comum ao longo da obra: trata-se de um texto compacto, saturado de abreviaturas, que regista cinquenta e sete linhas por cada fólio. Encontramos, todavia, também com alguma frequência, aquela que é praticamente a única variante em termos de mancha gráfica:

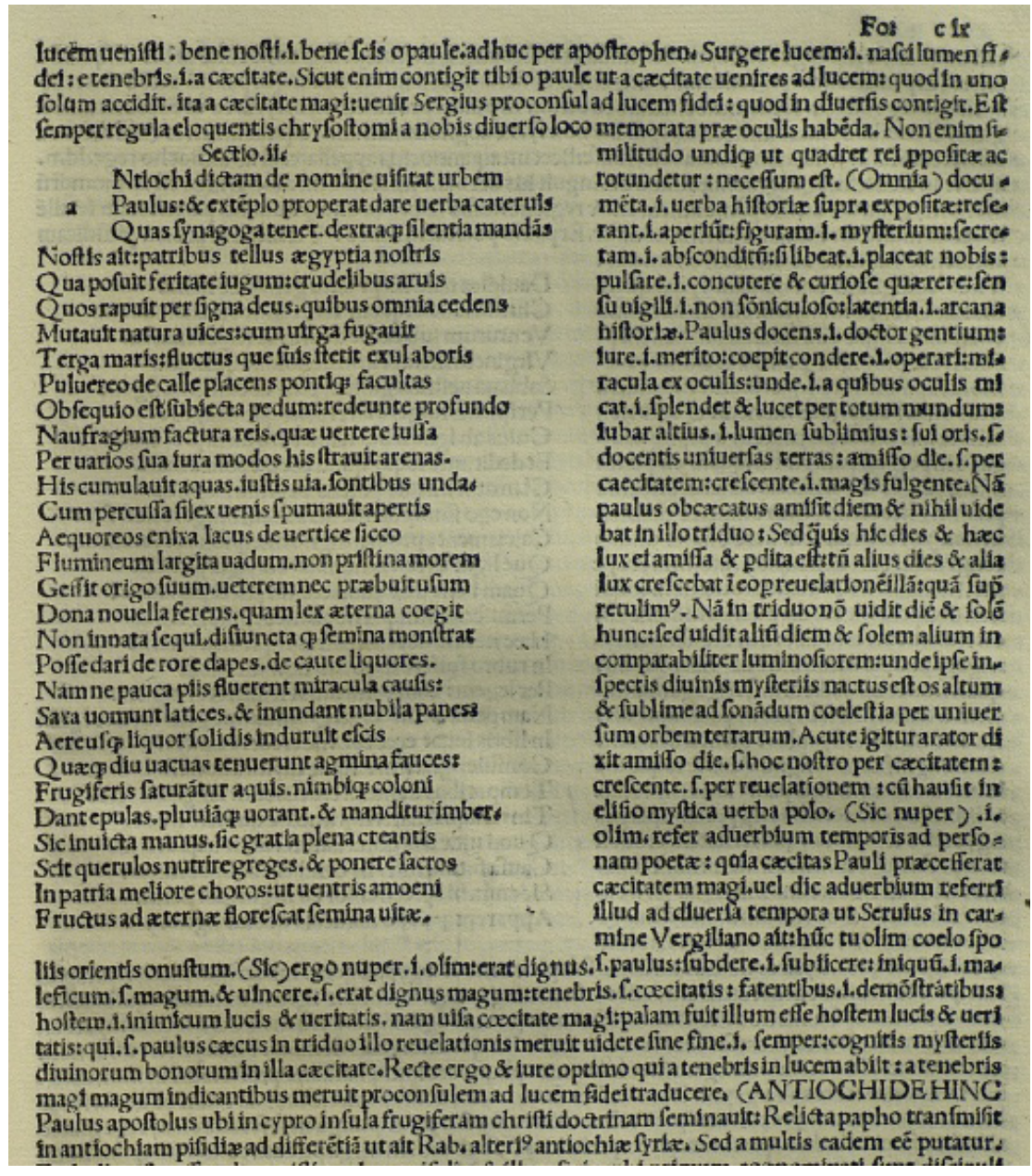

Existe um fólio semelhante a este sempre que Barbosa muda de secção, transcrevendo um novo conjunto de versos da Historia apostolica aratoriana, ordinariamente encostados à margem esquerda. A imagem deixa transparecer o cuidado no aproveitamento de toda a página: é transcrita uma secção do poema, mas todo o espaço em seu redor é preenchido com comentários. Sabemos que o humanista passa de secção não porque haja qualquer corte ou espaçamento no texto, mas por transcrever em maiúsculas a primeira palavra ou expressão da secção seguinte. Neste caso concreto, a análise da segunda 
secção começa na antepenúltima linha da imagem em ANTIOCHI DEHINC. A maiusculação da segunda palavra destina-se a vincar melhor a passagem da primeira para a segunda secção, dado que Dehinc pertence ao comentário barbosiano e não ao poema de Arátor. Este procedimento é uma espécie de marcação de novo capítulo na obra.

Por outro lado, o Comentário revela uma quase total ausência de capitais ornamentadas. Era suposto o ilustrador desenhar a primeira letra no início de cada secção do poema, mas, das quarenta e oito capitais previstas, falta ilustrar quarenta e cinco, uma vez que o espaço em branco lhes está devidamente reservado. Reproduzimos uma das três capitais ornamentadas, referente ao início da primeira secção do segundo livro:

(SPIRITVSACCENSAM.) Haetenus Arator petri Barionæ prazdicationé:miracu la:carceré:cateraqg narrauit:qux ad ípfum princípéapoftolorí attínebăt. Nuncín hoc fectido libropaulitexítur hiftoria:\& clágor doctrină euangelícă fonans ubíq: nullisq̧3 nõterris, \& $x$ infulis exauditus defcribitur.In calce tero oper] corona utriuf̧̧ exponitur : qū ad martyríi gloríáamboRomam perue
ARATORIS SVBDIACONI ROMANAE EC fix cardinalis apoftolicx hiftorix; Liber fecundus. Secto prima.

ल Sub modío lucere uetāstfecernite faulum Dixitin oris opus. qué mox facrauitetité Omia pofie dedit.Cyprum falamina quelínquens Pergie adire paphum: qua ferturamoribusolim

Cuesta Gutiérrez, tendo uma perspetiva mais global das obras editadas na tipografia a que Barbosa recorreu, afirma: "Las obras de Porres llevan abundancia de curiosos grabados y letras floreadas"12. Ora, imagens não aparecem nem era previsto aparecerem no comentário barbosiano, mas as "letras floreadas" confirmam-se, faltando saber a razão de o ilustrador ter trabalhado tão pouco, pois apenas ornamentou uma capital no primeiro livro (fl. iii vo ) e duas no segundo livro (fl. cii e ciiii vo). Os restantes casos podem ser exemplificados pela imagem que se segue, correspondente ao início da terceira secção do segundo livro (fl. cxi):

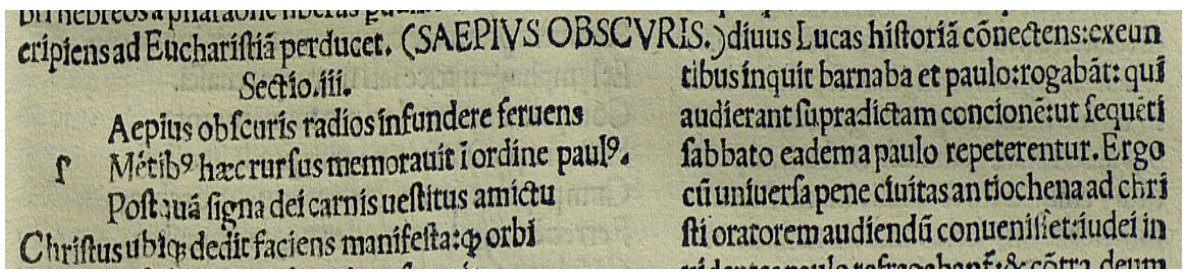

Como se pode observar, está reservado o espaço para a ilustração da primeira letra do primeiro verso do poema - neste caso o $S$ de Saepius -, mas a ilustração não está feita. $\mathrm{Na}$ imagem supra, é visível a passagem da segunda para a terceira secção no ponto em que o comentador transcreve em

${ }^{12}$ Luisa Cuesta Gutiérrez, op. cit., p. 24. 
maiúsculas o início do verso da secção seguinte: SAEPIVS OBSCVRIS. E se, neste caso, há uma razão objetiva para o uso de maiúsculas, a verdade é que no conjunto do Comentário se nota alguma arbitrariedade na sua utilização. Por exemplo, surgem esporadicamente maiúsculas sem qualquer razão justificativa no meio das frases e, quanto aos antropónimos e topónimos, estes aparecem arbitrariamente grafados tanto com maiúscula inicial como com minúscula. Ilustre-se este último caso a partir do fólio lxxxviii vo: Aeneam, Lucam, Arator, Perseus, mas plinio, palestinae, strabo, ouidio, india, entre outros. A este nível e ainda no mesmo fólio, a grafia do nome pomponius Mela é reveladora da flutuação de critérios. Resta a dúvida: a quem imputar tal arbitrariedade de critérios? Ao autor ou ao tipógrafo? A análise global do texto deixou-nos concluir, todavia, da existência de três casos em que a maiúscula é regularmente usada: o início de frase, o início de verso (os de Arátor) e o início de secção.

A pontuação levanta problemas semelhantes, que naturalmente se refletem na compactação do texto original, já que este apresenta apenas quatro sinais: o ponto final, o ponto de interrogação, os parênteses e os dois pontos, correspondendo este último com grande frequência à vírgula. Ademais, a dificuldade na leitura do texto é acrescida pela ausência de parágrafos ao longo da obra. E se, na transcrição do poema de Arátor, os versos aparecem em linhas separadas, já quando Barbosa cita conjuntos de versos no corpo do Comentário não há qualquer separação. Exemplos disso são os catorze hexâmetros datílicos da sua própria autoria que Barbosa cita no fólio cxxxviii em seis linhas, ou dez versos da Farsália, de Lucano, que ocupam apenas quatro linhas no fólio cxxxii.

Mas um dos fatores que mais contribui para a compactação do texto barbosiano é, sem dúvida, a grande frequência de abreviaturas. Por vezes, o seu desdobramento é dificultado por dois fatores. Primeiro, Barbosa usa abreviaturas que não se encontram em qualquer dicionário, a exemplo de .n.p. (fl. cxxxiii vo 1.30$)$, nomen proprium; e outras que, embora possamos admitir o seu eventual registo, não são habituais, como hõ, homo (fl. cxxi vo 1.5$)$, e cãm, causam (fl. cxxiii $\left.\mathrm{v}^{0}, 1.50\right)$. Em segundo lugar, nem sempre a mesma abreviatura deve ser desdobrada da mesma maneira, casos, por exemplo, de .q., passível de corresponder a quondam ou a quasi, e de tũ, desdobrável por tunc, mas também por tum. A questão das abreviaturas pode ser ilustrada a partir das cinco linhas retiradas do fólio cxxxii $\mathrm{v}^{\mathrm{o}}$, que reproduzimos abaixo e de que fazemos transcrição:

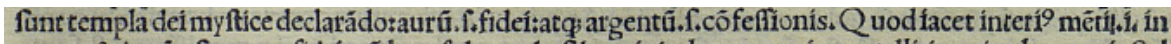
mente $\&$ in aia.f.aurum fideí:nô latet fub corde.Chomínis dura materies metalli:íauri uel argentí: fed aptius. 1.apte $\&$ clare:exagitat.i.mouet.f.mofes fub nốie auríillud.f.fidei aurú:quod chrift 9 amat. Mẹs obtulitaurú.f.ín templo dei:cuí fuerit fides preciofa.i.aurea \& magníprecil.Quinuiliusargentú ẻ auro:

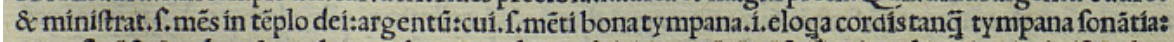


sunt templa Dei, mystice declarando; aurum, scilicet, fidei; atque argentum, scilicet, confessionis. Quod iacet interius menti, id est, in mente et in anima, scilicet, aurum fidei; non latet sub corde, scilicet, hominis; dura materies metalli, id est, auri uel argenti; sed apertius, id est, aperte et clare; exagitat, id est, mouet, scilicet, Moses sub nomine auri; illud, scilicet, fidei aurum, quod Christus amat. Mens obtulit aurum, scilicet, in templo Dei; cui fuerit fides pretiosa, id est, aurea et magni pretii, quia uilius argentum est auro; et ministrat, scilicet, mens in templo Dei; argentum cui, scilicet, menti; bona tympana, id est, eloquia, cordis, tanquam tympana sonantia

Existem abreviaturas correntes, como o til, que corresponde à nasal $m$ ou $n$ (declarãdo, mẽti, aĩa, nõ); o sinal ${ }^{9}$, que abrevia a terminação "us" (inter $\left.i^{9}\right)$; ou a enclítica que, abreviada por $q_{3}\left(a t q_{3}\right)$. Contudo, as abreviaturas mais frequentes são .i. e .s., correspondentes a id est e scilicet, que podemos traduzir por isto $e ́$, quer dizer. A repetição exaustiva destas duas expressões, que introduzem a explicação da ordem ou do significado de um vocábulo ou expressão, confere alguma monotonia ao Comentário, mas confirma o interesse didático desta obra, destinada fundamentalmente aos discípulos, tal como Barbosa afirma repetidamente nos prefácios aos dois livros. Na verdade, embora notemos neste caso alguma falta de erudição, o comentário barbosiano fornece-nos, por outro lado, um magnífico testemunho do ensino do latim e da literatura latina nos inícios de Quinhentos.

Deixámos para o fim uma questão fundamental, sobretudo se atendermos ao epíteto do nosso autor: como aparece o grego no Comentário? Nesta, como em todas as outras obras de Aires Barbosa publicadas em Salamanca, a língua de Homero é sempre transcrita em caracteres latinos. Ora, isso pode parecer estranho, tendo em conta a mestria reputada a Aires Barbosa nesse âmbito e a grande frequência com que aparecem expressões, frases e citações em grego: autores como Luciano, Aristófanes, Píndaro e Homero, por exemplo, são quase sempre citados em grego. Mas o facto explica-se pelas contingências técnicas da tipografia salmantina da época, que não tinha caracteres gregos. É certo que, frequentemente, as citações em grego são de menor dimensão, em geral pequenas frases ou títulos de obras, mas esporadicamente deparamo-nos com textos de alguma dimensão, como no fólio cxlii, onde Barbosa transcreve um passo de Demóstenes (apresentamos também a transcrição do texto em caracteres gregos):

\section{aabua0. Lategubiactior tepeitasincumbitutuerbis utar Demolthenís utís naucleron pantepífotería praxanta cai pafi catefcetuafanta toploion aphon hypelambane fothefeftai:eita cheimonichrifamenon cal ponefanton auto tonfceuson icai fyntribenton holos:tesnauagias aicioto. Neć.n. fempars fíné cóti}

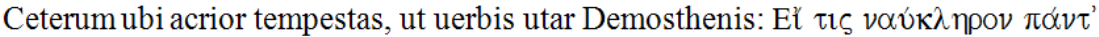

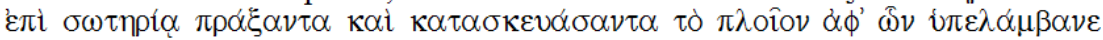

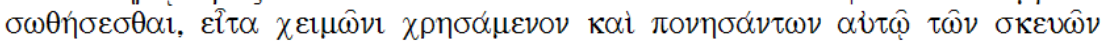

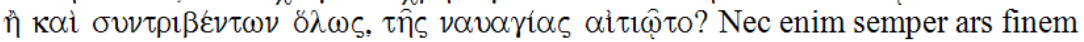


A transcrição do grego em caracteres latinos, que constitui uma enorme dificuldade para quem lê e transcreve o original, pode, no entanto, ter algum interesse para o estudo da pronúncia da língua helénica no início do século XVI. Apresentamos dois exemplos referentes à pregação de S. Paulo em Atenas, comentada no segundo livro. No primeiro caso, o humanista refere uma entrada da Suda (no 1272), que explica a origem do gentílico "Cecrópidas" para designar os Atenienses (fl. cxxiiii); no segundo, Barbosa cita um passo de Luciano (Herm., 64), onde diz que os juízes julgavam no Areópago de noite para que se atendesse àquilo que era dito e não a quem o dizia (fl. cxxiii vo):

onto genos ocefe tas athenas: hothen cecroüidæ oiatheginltaurauit. Vñ \& fúdás cecrops aigyptios Cecropíd $x$ ficut a romulas: hothen cecropid $x$ oi athenaíol. Dictitur ergo atheniefes a cecrope rege

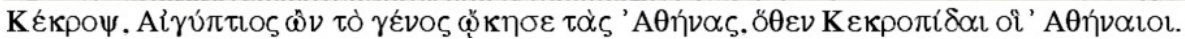

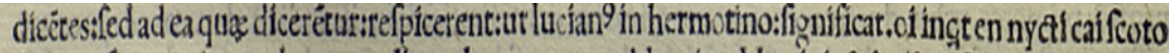
dicazoyfinaosmiestus legontasalles ta legomena apsblepoien. Meninit \& hui? côfuetudinis macros

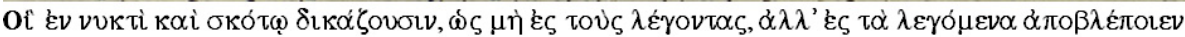

O cotejo que aqui estabelecemos permite-nos tirar algumas conclusões a respeito da pronúncia do grego ao tempo do humanista: a vogal inicial ou ditongo com espírito áspero não era aspirada $(o i$, os) nos monossílabos, mas era-o em palavras com mais do que uma sílaba (hothen); o thêta era sempre aspirado (athenas); o êta correspondia ao som /e/ (ocese), mas em sílaba final liase /i/ (mi). Na transcrição latina é-nos impossível verificar a distinção, ao nível da prosódia, entre épsilon e êta ou entre ómicron e ómega, dado que a grafia é sempre igual ( $\underline{e}$ e $\underline{o}$, respetivamente), mas cremos que ela era feita.

Em suma, os originais salmantinos da obra barbosiana apresentam desafios a qualquer latinista, mas podem lançar pistas para quem se aventura na edição crítica de outros autores da mesma época. A leitura não é de todo isenta de dificuldades e cremos ser esse um dos motivos pelo qual uma obra tão importante como a do humanista aveirense só agora, no século XXI, começa a ser reeditada. Por outro lado, as edições barbosianas são de grande relevo para a história da imprensa em geral, e particularmente para a história da imprensa em Salamanca. 



\section{LuCrécio e Aires Barbosa \\ (Comentário a Arátor, Historia Apostolica 2.11.17; \\ LUCR. 2.999-1001)}

Ana María S. Tarrío

Universidade de Lisboa

Como diz Lucrécio: «Realmente, o ciclo inverte-se: o que antes veio da terra/ retorna à terra, e o que desceu das regiões etéreas/ de novo o recebem os templos estrelados do céu». Isto é verdade, na medida em que está em harmonia com a piedade cristã.

Aires Barbosa ${ }^{1}$

Com esta sumária naturalidade citava Aires Barbosa, em Salamanca, em 1516, a apologia do ateísmo e do materialismo mais entusiasmada da literatura romana (De rerum natura 2.999-1001) nada menos do que num comentário a uma epopeia bíblica sobre as gestas dos apóstolos Pedro e Paulo, escrita no século VI (Arátor, História Apostólica) ${ }^{2}$.

Nem o próprio Giovanni Pico della Mirandola, artífice da conciliação entre paganismo e cristianismo, teria ousado tanto. Muito pelo contrário, trinta anos atrás evocara o nome de Lucrécio como reprovável antítese do teólogo medieval Duns Escoto, na famosa e polémica carta a Ermolao Barbaro (de 3 de Junho de 1485), em breve considerada um ensaio sobre a superioridade da Filosofia/Teologia sobre a Retórica. Para Mirandola era sem dúvida preferível à mens insipiens do eloquente poeta latino o os insipidum do teólogo medieval.

Porque «podemos viver sem língua, incomodamente, sem dúvida, mas sem coração não podemos de todo viver» ${ }^{3}$.

A transmissão manuscrita de Lucrécio e a história da sua recepção durante a Antiguidade Tardia e a Idade Média permitiriam justificar, no entanto, este aparente oximoron. A fragmentação antológica do De rerum natura, realizada

${ }^{1}$ Vt enim ait Lucretius: "cedit item retro, de terra quod fuit ante, / in terram, et quod missum est ex aetheris oris/id rursum caeli stellantia templa receptat». Hoc uerum est quatenus Christiane pietati congruit, ed. e trad. José Henrique Rodrigues Manso, Comentário de Aires Barbosa ao Segundo Livro da Historia Apostólica de Arátor, Lisboa, 2011, pp. 464-465; cf. Lucr. 2.999-1001.

2 Aires Barbosa, Aratoris Cardinalis Historia Apostolica cum Commentariis Arii Barbosae Lusitani, Salmanticae, in aedibus Ioannis Porris, Mense Aprili MDXVI. Doravante citaremos sempre o comentário barbosiano a partir da edição de Manso, op. cit.

${ }^{3}$ Giovanni Pico della Mirandola, Opera omnia, fac-símile da ed. Basileia, 1557, Hildesheim, 1969, vol. I, p. 352: uiuere sine lingua possumus, forte non commode, sed sine corde nullo modo possumus. 
sobretudo pelos autores gramaticais ${ }^{4}$, havia destilado a sua elegância formal e mestria métrica inigualáveis e havia inutilizado profilacticamente o seu potencial veneno, transformados os seus versos em modelos de escrita poética, úteis sobretudo para a composição de hexâmetros.

Esta forma de utilização, de abonada tradição medieval, seria à primeira vista plausível na pena de um professor universitário que consagrou metade dos seus títulos publicados a conteúdos didácticos gramaticais e mormente métricos (Relectio de uerbis obliquis, Salamanca, 1511; Epometria, Salamanca, 1515; Prosodia, Ortographia, Salamanca, 1517).

A aplicação antológico-didáctica não esgota, contudo, o significado desta ocorrência.

Ela não responde a um Lucrécio reduzido a pura côdea métrica, a mero envoltório formal, na medida em que se apresenta na qualidade de abonação a um conceito do autor patrístico comentado, como resultado de uma associação de sentido. Barbosa lembrou-se destes versos do livro segundo do De rerum natura ao explicar um passo de Arátor relativo ao regresso dos seres à sua origem celeste, regresso que teria como garantia ou penhor a semelhança do mundo criado (a fabrica pulchra) ao seu Criador, isto é, a sua beleza ${ }^{5}$. A ideia de que as coisas terrestres guardam a aparência da sua semente celestial podia efectivamente incitar um leitor cristão de Lucrécio a evocar os semina rerum, recorrentes no livro segundo do De rerum natura e em especial o passo que começa por Somos pois todos oriundos de semente celestial (Denique caelesti sumus omnes semine oriundi, Lucr. 2.991), sequência na qual se inserem os três versos citados pelo humanista luso.

Como este identifica claramente o autor latino citado, não se poderá inscrever nessa "congiura del silenzio" cunhada por Traina no seu estudo sobre a transmissão textual de Lucrécio ${ }^{6}$. No entanto, a citação também sobressai pelo que não diz, pelo seu excessivo laconismo.

Aos seus eloquentes silêncios dedicamos estas páginas.

${ }^{4}$ Os autores gramaticais detêm, como é sabido, um papel fundamental na tradição indirecta de De rerum natura, sobretudo Nónio Marcelo, mas também Prisciano, Macróbio, Sérvio, Probo, Carísio, como apontaram os principais nomes do estudo da sua transmissão textual (Pizzani, Flores, Pasquali). Vd. V. Sivo, «Fortuna medievale di un verso lucreziano (da Micone di SaintRiquier a Giovanni Balbi)», Invigilata Lucernis 10 (1988) 305-25; cf M. D. Reeve, «The Italian Tradition of Lucretius», Italia Medioevale e Umanistica 23 (1980), 27-48.

${ }^{5} \mathrm{O}$ comentário parte concretamente da explicação da expressão pro pignore de Arátor 2.9.15-17: ne fabrica pulchra Creantis/ quae plasmata solo caelestis imaginis instar/ traxis et auctoris speciem pro pignore gestat; Barbosa, Aratoris..., op. cit.: pro pignore, scilicet, reditus caelestis et in patriam illam antiquam, si recte egerimus et pie innocenterque uixerimus. Vt enim ait Lucretius..., pp. 456, 464.

${ }^{6}$ A. Traina, «Lucrezio e la "congiura del silenzio"», in Poeti latini (e neolatini): note e saggi filologici. Bologna, 1975, pp. 81-91. 


\section{O Lucrécio de Lactâncio}

Tanto o passo lucreciano escolhido por Barbosa como a sua interpretação em chave cristã com alta probabilidade encontraram inspiração em Lactâncio, o qual citara exactamente os mesmos versos para apontar que até o próprio Lucrécio, esquecido do que tinha asseverado e do dogma que defendera, vencido pela verdade, tinha sucumbido à razão verdadeira, ao descrever o regresso dos seres à sua origem celeste ${ }^{7}$.

A primeira ausência em torno desta citação seria, pois, o nome de Lactâncio. Tratava-se de autor que o professor salmantino conhecia bem, como deixam ver diversos passos do seu comentário a Arátor. Neste tratado, o autor patrístico surge precisamente citado como autoridade sobre as virtualidades positivas da utilização dos argumentos pagãos contra eles próprios (Inst. 5.4.3) ${ }^{8}$.

Por seu lado, Lactâncio deixou-nos suficientes evidências acerca da sua consideração por Lucrécio, apesar do explícito capítulo décimo segundo do mesmo livro sétimo das suas Institutiones: De immortalitate animae contra Lucretium et Epicurum. A sedução do poeta romano foi tal que, ainda que obviamente rejeitando as suas posições sobre a mortalidade da alma e a sua crítica radical a todas as religiões, Lactâncio não resistiu a atribuir a quota-parte de delírios da sua obra ao nefasto e diabólico Epicuro ${ }^{9}$, a tentar aproximá-lo da sua própria causa ${ }^{10}$ e a sublinhar com certa emoção os lugares onde Lucrécio não tinha errado ${ }^{11}$.

Barbosa parece ter herdado esta forma de dissociação entre Lucrécio e Epicuro que encontrava em Lactâncio. No seu comentário a Arátor não falta

${ }^{7}$ Lact., Inst. 7.12.5: [...] denique idem Lucretius oblitus quid adsereret et quod dogma defenderet, hos uersus posuit: "cedit item retro, de terra quod fuit ante,/in terram, sed quod missum est ex aetheris oris,/id rursum caeli fulgentia templa receptant/" quod eius non erat dicere qui perire animas cum corporibus disserebat: sed uictus est ueritate et inprudenti ratio uera subrepsit.

${ }^{8}$ Manso, op. cit., p. 379, n. 345, p. 765, n. 196-197, p. 755. Barbosa invoca também Lactâncio no tema da crítica da adoração de ídolos e das práticas da adivinhação (Lact., Inst. 2.14.10-12; $2.16 .1 ; 2.16 .3 ; 4.27 .1)$.

${ }^{9}$ Lact., De opificio Dei 6.1: Non possum hoc loco teneri quominus Epicuri stultitiam rursum coarguam: illius enim sunt omnia quae delirat Lucretius.

${ }^{10}$ Lact., Inst. 7.27.6: hunc sequamur omnes, hunc audiamus, huic deuotissime pareamus, quoniam solus, ut ait Lucretius, / ueridicis hominum purgauit pectora dictis / et finem statuit cuppedinis atque timoris lexposuitque bonum summum, quo tendimus omnes, /quid foret, atque uiam monstrauit, limite paruo / qua possemus ad id recto contendere cursu; Lact. Epitome 20.4: quorum stultitiam Lucretius grauiter incusat dicens: et faciunt animos humiles formidine diuum / depressos que premunt ad terram: / qua reddunt nec intellegunt quam uanum sit ea timere quae feceris, aut ab iis aliquod sperare praesidium quae muta et insensibilia nec uident nec audiunt supplicantem.

${ }^{11}$ Lact. Inst. 6.10.7: itaque non errat Lucretius, cum dicit:/ denique caelesti sumus omnes semine oriundi, / omnibus ille idem pater est. Wolfgang Bernard Fleischmann, «Lucretius Carus, Titus», in P. O. Kristeller, Catalogus translationum et commentariorum, Washington, 1971, p. 357, comenta a extensiva assimilação de Lucrécio por parte de Lactâncio, apesar da condenação programática das suas ideias, e o uso de Lucrécio contra si próprio. 
a explanação da breve alusão ao triunfo do apóstolo Paulo sobre as seitas epicuristas e estóicas (por sua vez relativa aos Actos dos Apóstolos 17.18). A explicação do humanista consiste numa capciosa síntese da teoria de Epicuro, seita contraditória e ridicularizável doutrina baseada no exclusivo prazer do corpo, recorrendo a Firmiano, Marciano Capela e até Cícero, Horácio ou Platão. Nesta síntese brilha pela ausência qualquer alusão a Lucrécio ${ }^{12}$.

A Epicuri stultitia de Lactâncio ecoará também nas mordazes alusões da Antimoria de Barbosa, obra publicada em 1536. A sua crítica de Epicuro omite o elogio lucreciano do filósofo que abre o livro III do De rerum natura assim como o uso desta homenagem (Lucr. 3,1-30) no elogio de Cristo composto por Arnóbio no Aduersus nationes. O alvo do humanista luso era menos o Epicuro antigo do que o diálogo Epicureus de 1518, onde Erasmo sustentava uma forma de possível conciliação do epicurismo e do cristianismo, na esteira do De uoluptate de Lourenço Valla. Na sua interpretação capciosa e injusta, o Louco (Erasmo) «na santidade de Jesus não acredita, prefere acreditar em Aristipo ou Epicuro, para quem Deus é ventre e o sumo bem consiste nas suas impurezas» ${ }^{13}$. O Epicureus erasmiano omitia também, por seu lado, qualquer referência a Lucrécio. Este, no entanto, ocorre numa rápida refutação satírica da alma Venus como motor do mundo no Elogio da Loucura.

Não restam dúvidas de que o Lucrécio de Lactâncio, brilhante poeta vítima de intermitentes delírios, foi do conhecimento do humanista português. $\mathrm{E}$, no entanto, ao citar Lucrécio, Barbosa não sentiu qualquer necessidade de se defender sob o poderoso escudo, prestigiante e protector, do nome do autor patrístico, um dos privilegiados pelo reuocare ad fontes humanístico da sua formação. O seu mestre Policiano, como recordava Francisco Sánchez de las Brozas, privilegiara Lactâncio, em detrimento de Varrão, na caracterização do pastor Branco, na sua Silva Nutricia (vv. 213-215) ${ }^{14}$.

Ora a citação ou evocação do nome de Lucrécio, desde a época patrística até ao momento dos célebres lucrecianos, posteriores a Aires Barbosa, como Ronsard ou Montaigne ${ }^{15}$, parece ter exigido a correspondente retractação

${ }^{12}$ Arátor 2.8.47-49. Veja-se o texto latino e a tradução deste passo em Manso, op. cit., p. 364, e o comentário de Barbosa ibid., pp. 389-391.

${ }^{13}$ Aires Barbosa, Antimoria, ed. e trad. de Walter de Medeiros, Aires Barbosa - escorço biobibliográfico seguido do texto e versão da Antimoria, tese de licenciatura, Fac. Letras Univ. Lisboa, 1953, p. 166: [...] Sancto non credit Iesu/ Morus: Aristippo plus credit, plus Epicuro/Quis deus est uenter, quis summa in turpibus eius.

${ }^{14}$ Luis Merino Jerez, «Las Silvae de Poliziano comentadas por E1 Brocense», Humanistica Lovaniensia XLV (1996), 426.

${ }^{15}$ Segundo E. Tilson, «La forme demeure et la matière se perd». Vd. «Emplois du De rerum natura chez Ronsard», in La renaissance de Lucrèce, Paris, 2010. pp. 201-222, 203, n.2 e 204. Ronsard terá reformulado o atomismo integrado no neoplatonismo florentino, com a sua equiparação dos átomos e as ideias platónicas. Sobre Lucrécio em Montaigne veja-se: W. G. Moore, «Lucretius and Montaigne», Yale French Studies 38, 109-114; M. A. Screech, Montaigne's 
dos conteúdos ateus da obra citada, isto é, demandava uma forma de autoexculpação, da parte do leitor e admirador da poesia de Lucrécio, de qualquer veleidade heterodoxa. Como nota Michael Reeve, já o primeiro editor de Lucrécio (Brescia, c. 1473) sentiu a necessidade de justificar a sua escolha, protegendo-se sob o argumento da sua presença em Vergílio, mesmo meio século depois da ampla divulgação da tradução bruniana das obras de S. Basílio, com a sua exaltação do proveito da literatura pagã para os cristãos ${ }^{16}$.

Neste sentido, surpreende a total omissão de qualquer justificação ou esclarecimento desta citação por parte de Aires Barbosa, um comentarista atacado por prolixo pelos seus contemporâneos professores salmantinos (acusação da qual Barbosa se defende com afinco ${ }^{17}$ ) e pela sua vertente ortodoxa e apologético-cristã, culminada na sua obra Antimoria ${ }^{18}$.

Esta segunda espécie de omissão de toda a problematização doutrinal dificilmente poderá atribuir-se a desconhecimento por parte de Barbosa dos conteúdos materialistas e irreligiosos da obra citada. Pode, no entanto, compreender-se à luz da sua formação humanística.

\section{O Lucretius integer e a formação italiana de Aires Barbosa.}

O expeditivo menospreço pelo insipiens Lucretius de Pico della Mirandola estava longe de ser consensual ou representativo no seu próprio meio humanístico.

A ocorrência barbosiana de 1516 surgia quase um século após o renascimento do Lucrécio integer, graças a Poggio Bracciolini e à sua descoberta, em 1417, durante o Concílio de Constança, do códice do século IX (O). Durante toda a segunda metade do século XV, Lucrécio foi objecto de evidente apreço, estudo e emulação, particularmente na chamada escola neoplatónica, a qual apelava a uma origem comum a filósofos e poetasteólogos: a palavra magmática originária. Este expediente permitia resolver obstáculos como o problema crucial da expulsão dos poetas na República de Platão e neste quadro a obra lucreciana e até a física epicurista conheceram uma forma de integração ${ }^{19}$.

Annotated Copy of Lucretius, Genève, 1998; M. Wiesmann, «Lucrèce», in Dictionnaire de Michel de Montaigne, ed. P. Desan, Paris, 2004, pp. 610-612.

${ }^{16}$ M. Reeve, op. cit., p. 29.

${ }^{17}$ Veja-se, entre outros passos, o explícito poema que acompanha o comentário: «O mesmo Aires a um indivíduo que dizia ser demasiado longo este comentário», na trad. de Manso, op. cit., p. 739.

${ }^{18}$ José Pereira Tavares, «Tradução do poema Antimoria e dalguns epigramas de Aires Barbosa», Arquivo do distrito de Aveiro 26 (Aveiro, 1960), pp. 9-82; Sebastião Tavares de Pinho, «Aires Barbosa, pedagogo e poeta», supra, capítulo quarto deste livro.

${ }^{19} \mathrm{~S}$. Gambino Longo, «Corriger Aristote par Lucrèce: la physique épicurienne à travers 
Barbosa tinha-se formado na Itália precisamente no tempo do «Lucretian network», na expressão de Alison Brown ${ }^{20}$, que marcara a ascensão do poeta latino a modelo de escrita, particularmente visível nas obras originais de Pontano e Policiano ${ }^{21}$.

Com efeito, os Diálogos de Pontano Meteora, Urania e Actius, publicados já em finais do séc. XV, muito deviam à leitura do De rerum natura. Distinguemse por uma qualidade, também cara a Aires Barbosa, como veremos em seguida: a declarada intentio da educação moral dos homens. Outro instigador da imitação neolatina de Lucrécio foi Bembo, por cuja intervenção foi impresso o De principiis rerum de Scipione Capece. Para Bembo, Lucrécio, juntamente com Vergílio, era a expressão da máxima elegância e pureza do latim, pureza formal coerente com a supremacia do período republicano na história romana. Esta abordagem estético-política, que conheceu dois momentos de auge (Poggio e Lambin, já no Cinquecento), confluirá nos apelativos de sermo purus e elegantia Lucretii introduzidos por Pietro Vettori no seu comentário à Poética de Aristóteles de $1560^{22}$.

Por seu lado, Policiano não foi apenas admirador e emulador de Lucrécio ${ }^{23}$, mas também um dos humanistas que se ocuparam em sarar os multíplices uulnera dos obscuros versos lucrecianos, como patenteia o exemplar manuscrito Laur. 35.29. Este ostenta anotações do humanista, relevantes sobretudo porque apontam para o manuseio directo de um dos dois testemunhos mais antigos (séc. IX) da obra latina: o referido códice O (Leiden Voss. Lat. F 30) e/ou de outros manuscritos relacionáveis com este ${ }^{24}$.

l'aristotélisme renaissant», Cabiers philosophiques 83 (Juin 2000) 33-50; C. P. Goddard, "Pontano's use of the didactic genre: rhetoric, irony and the manipulation of Lucretius in Urania», Renaissance Studies 5 (1991), 250-62.

${ }^{20} \mathrm{O}$ estudo foca sobretudo três figuras, diversamente lucrecianas: M. Ficino, B. Scala e N. Maquiavel: Alison Brown, The Return of Lucretius to Renaissance Florence, Cambridge, 2010. Uma útil síntese da actividade filológica lucreciana do chanceler de Florença Bartolomeo Scala e do seu genro Marulo pode ler-se em Gerard Passannante, The Lucretian Renaissance: Philology and the Afterlife of Tradition, Chicago/ London, 2011.

${ }^{21}$ Assim, no Rusticus de 1483 reelabora Lucr. 5.737-747. Fleischmann, op. cit., p. 353. Estas ocorrências devem inserir-se, como veremos, na contemporânea redescoberta de Lucrécio como modelo sublime de escrita poética. C. Isabelle Pantin, «Le De rerum natura comme modèle poétique. Réflexions sur quelques divergences entre l'Italie et la France», in La renaissance de Lucrèce. Paris, 2010, pp. 180ss.

${ }^{22}$ Isabelle Pantin, op. cit., pp. 180ss. Cr. Susanna Gambino Longo, «La spositione de Lucrèce par Girolamo Frachetta et les théories poétiques de la fin du XVIe siècle en Italie», in La renaissance de Lucrèce, Paris, 2010, pp. 185-200.

${ }^{23}$ Ida Maier aponta por exemplo a importância de Lucrécio na configuração do Amor como força cósmica na obra de Policiano: Ida Maier, Ange Politien. La formation d'un poète humaniste (1469-1480), Genève, 1966, pp. 292, 324.

${ }^{24} \mathrm{O}$ nome de Lucrécio consta já no inventário de manuscritos elaborado por Piero de Médicis em 1456, revelador do rico espólio de exemplares de autores antigos da biblioteca desta família, da qual amplamente se servirá Policiano. Por outro lado, conserva-se correspondência 
Barbosa não deixará de manifestar, já como professor salmantino, a sua extensa dívida e profunda admiração por Policiano. No mesmo comentário a Arátor denomina-o Politianus meus ${ }^{25}$ e meus Angelus ${ }^{26}$. Este humanista, juntamente com Ermolao Barbaro e até o 'anti-lucreciano'Pico della Mirandola configuraram a tríade de bastiões da expulsio barbariei homenageada por Barbosa num dos seus epigramas:

\section{Rara auis in terris qualis Mirandula Picus}

barbariae aut hostis Barbarus ille fuit

Angelus aut priscis cedens quia non sit in illis ${ }^{27}$

Esta forma de devoção caracteriza o célebre grupo de alunos portugueses de Policiano, consignados na subscriptio do incunábulo bodleiano da Naturalis Historia (Bodleian Library Auct.Q.1.2). Com efeito, é possível seguir a história do impacte dos auctores antigos ensinados pelo mestre florentino nas obras posteriormente elaboradas por humanistas portugueses, de maneira directa e indirecta, como ilustra o caso particular de Plínio em Martim de Figueiredo e em João Rodrigues de Sá de Meneses, ou dos autores elegíacos neste último. Com efeito, o alcaide-mor de Porto, apesar de não ter sido aluno do humanista florentino, formou-se no Paço manuelino determinado pelo seu magistério ${ }^{28}$.

A ocorrência lucreciana de Barbosa (com a sua referida naturalidade ou laconismo) deve situar-se neste primeiro grande momento da recepção de Lucrécio ${ }^{29}$ que coincide com o período da sua formação. Se o humanista luso apresenta o passo lucreciano sob o prisma bíblico, Ficino, atento leitor

entre este e Pomponio Leto, que refere o empréstimo de um exemplar de Lucrécio por este último a Policiano. Ida Maier, op. cit., pp. 65, 428, 433. Cf. Reynolds, Texts and Transmission, s.v. «Lucretius», Oxford, 1986, pp. 218-222, n. 26, p. 221. Cf. Reeve, op. cit., pp. 22ss.

${ }^{25}$ Aires Barbosa, Aratoris..., op. cit., pp. 408-409: Vnde et Politianus meus notauit scaenas a Rufino Latine appellari attegias... Cf. Policiano, Misc., 9; Manso, op. cit., n. 390, p. 768. Medeiros, op. cit., pp. 14-25, oferece um conjunto de evidências da influência de Policiano na obra de Barbosa.

${ }^{26}$ Aires Barbosa, Idem Arius in Nebulonem grammatistam iactuose uanum, v. 15, ed. Manso, op. cit., p. 732 .

${ }^{27}$ Ed. Medeiros, op. cit., p. 27. Cf. Manso, op. cit., p. 34.

${ }^{28}$ A. M. S. Tarrío, «O Commentum de Martinho de Figueiredo (1529) e as lições plinianas de Policiano (Naturalis Historia, Bodleian Library Auct.Q.1.2) in Os clássicos no tempo: Plínio o Velho e o Humanismo Português, Lisboa, 2007, pp. 95-110; «A Naturalis Historia em Portugal», Paisagem e erudição no humanismo português, Lisboa, 2009, pp. 111-117.

${ }^{29}$ De acordo com Isabelle Pantin, op. cit., pp. 166-167, o regresso renascentista de Lucrécio conheceu dois momentos: uma primeira fase culminaria por volta de 1515 , quando aparece a edição de Andrea Navagero, no qual se insere o comentário que acompanhou a edição de Giovanni Baptista Pio de 1511. A segunda fase culminaria com a edição de Lambin e Van Giffen. Cf. C. A. Gordon, A bibliography of Lucretius, London, 1962. 
de Lucrécio, escrevera uma obra intitulada significativamente De inmortalitate animae.

\section{Lucretius potionatus. A indulgência}

Esta revalorização de Lucrécio, que desviava os olhos - à diferença da de Pico della Mirandola - do sentido final da obra, do seu radical materialismo e da sua apologia anti religiosa, para se concentrar na beleza e profundidade de muitos dos versos lucrecianos, apoiava-se na já vetusta teoria das intermitências na escrita dos livros do De rerum natura, consequência da proverbial loucura do seu autor.

Essa loucura fora particularmente estudada por Ficino, em cuja obra constitui presença relevante o non sanus Lucretius e os seus impia dicta, que o humanista tratou de confutar, segundo as palavras do seu amigo Policiano ${ }^{30}$. Seguindo a sua teoria da uacatio animae, Cornelius Agrippa, na sua obra De occulta Philosophia (obra que conheceu circulação manuscrita desde 1510), identificava Lucrécio, juntamente com Homero, entre os seres desequilibrados, os quais, por um súbito furor, escreviam poemas divinos que nem eles próprios compreendiam ${ }^{31}$.

A indulgência para com as flagrantes impiedades do poeta sublime era recorrente nas biografias lucrecianas, de alargada difusão desde as últimas décadas do século $\mathrm{XV}^{32}$. Assim acontece na Vita de um discípulo de Policiano, Pietro Crinito, inserida na sua obra De poetis latinis (Florença, 1505) ${ }^{33}$.

A recuperação da sua breve e romanesca vida prendera-se aliás com a vaga biográfica mais vasta relativa aos filósofos antigos, esplendidamente representada por Rafael na sua Escola de Atenas (1510-1512), sintomaticamente ideada para uma das salas do Vaticano, e que fora desenvolvida no humanismo quatrocentista sobretudo a partir da redescoberta e tradução latina de Diógenes Laércio, em circulação manuscrita desde a sua elaboração, entre 1424 e 1433, e

\footnotetext{
${ }^{30}$ Impia non sani turbat modo dicta Lucreti, Angelus Politianus Bartholomaeo Fontio, ed. Ida Maier, op. cit., p. 75.

${ }^{31}$ Cornelius Agrippa, De occulta Philosophia libri tres, Basileia (?), [s.1.], 1533, BNM R/16104, III, 31, fol. 104: Plerunque etiam uidemus homines melancolicos rudes, ineptos, insanos, quales legimus extitisse Hesiodum, Jonem, Tymnicum Calcidensem, Homerum et Lucretium, saepe furore subito corripi ac in poetas bonos euadere et miranda quaedam diuinaque canere etiam quae ipsimet uix intelligant. Veja-se o comentário a este passo de Raymond Klibansky, Erwin Panofsky, Fritx Saxl, Saturno y la melancholía, Madrid, 2006, 340, n. 353. 2000.

${ }^{32}$ G. Solaro, Pomponio Leto, Lucrezio, Palermo, 1993; Lucrezio: biografie umanistiche. Bari,

${ }^{33}$ Pietro Crinito, De poetis latinis, Florença, impr. Giunta, 1505, «Liber Secundus», fol. b 2 vo; cf. Leofranc Holford-Strevens, "Horror Vacui in Lucretian Biography", Leeds International Classical Studies 1.1 (2002), 1-23.
} 
de mais alargada difusão a partir da editio princeps de $1472^{34}$. Diógenes Laércio dedicou uma das mais extensas das suas Vidas, a décima, ao paradigma de Lucrécio, Epicuro ${ }^{35}$.

A carta dedicatória da tradução, escrita por Ambrogio Traversari a Cosme de Médicis, consagra e santifica a aproximação humanística aos príncipes da sabedoria secular (sapientiae saecularis principes), úteis para o estudioso laico pelas suas lições de virtude e continência, modéstia e frugalidade ${ }^{36}$. A leitura renascentista das Vidas dos Filósofos Antigos, como consigna a Escola de Atenas de Rafael, encerrava uma forma de reverente consideração e simultaneamente sublinhava a liberdade e a excelência da escolha cristã, a sua superioridade tanto mais magnificada pela eminência filosófica dos seus precedentes pagãos, que, muito embora a intervalos, participaram da luz natural da razão concedida por Deus.

O Lucrécio potionatus de Lactâncio, vítima de um furor comparável ao do próprio Vergílio, ressurgia, em consequência, na secção Poetae Vita das sucessivas edições impressas do De rerum natura à disposição do humanista português. Também não falta no comentário de Baptista Pio de 1511: ele escrevera alguns livros nos intervalos da loucura, tomado do furor, depois de ter ingerido uma poção amorosa ${ }^{37}$.

Paralelamente às manifestações de indulgência e de parcial integração de Lucrécio, não faltou na cultura humanística a pura aceitação do erro lucreciano, da sua condição de plenus mendaciorum, da sua grave distância relativamente a outros autores pagãos como Platão ou Cícero. A sua

${ }^{34}$ A. Sottili, «Il Laerzio latino e greco e altri autografi di Ambrogio Traversari», in Vestigia: studi in onore di Giuseppe Billanovich, ed. R. Avesani et al. (2 vols.), vol. 2, Roma, 1984, pp. 699745 .

${ }^{35}$ Diógenes Laércio, Vitae et sententiae philosophorum, trad. lat. Ambrosius Traversarius, ed. Benedictus Brognolus, Venetiis, per Peregrinum de Pasqualibus, 19 Julho 1493 (BNP INC. 874), «Liber Decimus», fols. lxxxxix-cxii. Na folha da Tabula deste incunábulo encontramos marca de posse: «Da livraria de São Bento de Xabregas». Este exemplar carece de página de rosto.

${ }^{36}$ Diógenes Laércio, op. cit., fol. ii, Fratris Ambrosii Diogenis Laertii opus ad Cosmam medicem epistola: [...] multa in his et dicta grauiter et facta constanter inuenias, ut non modo ex illorum libris fidem inuiolabilis ueritas capiat, uerum exemplis quoque religioni nostrae incitamentum uirtutis accedat, quodam foedum enim quodamque plenum dedecoris est, si christianum bominem et de deo suo pendentem et cui aeternae uitae spes certa sit, uirtuti et continentiae dare operam pigeat, cum gentiles uiros et a ueri cultu dei ac religione longe alienos probitati modestiae frugalitati caeterisque id genus animi humani ornamentis impensius studuisse comperit.

${ }^{37}$ Johannes Baptista Pius, «In Carum Lucretium .... auctore Pio...», In Carum Lucretium poetam Commentarij a Ioanne Baptista Pio editi:codice Lucretiano diligenter emendato ..., Bononiae,: typis excussoriis editum in ergasterio Hieronymi Baptistae de Benedictis Platonici Bononiensis, 1511, BNP RES. 461 A., fol. a: qui postea amatorio poculo in furorem uersus cum aliquot libros per interualla insaniae conscripsisset...; cf. ibid.: quoniam auctore Lactantio libro de opiticio Epicuri sunt omnia quae delirat Lucretius. 
leitura justifica-se porque faria brilhar com mais esplendor a verdade cristã nos olhos do leitor contemporâneo. Esta é a posição que encontramos na segunda edição aldina de Lucrécio, na carta introdutória dedicada pelo célebre impressor-humanista ao príncipe Pio Alberto de' Carpi, sobrinho de Giovanni Pico della Mirandola, seu discípulo desde 1485. O Lucrécio de 1515 seria o último trabalho de Aldo Manúcio e a carta dedicatória seria considerada o seu testamento espiritual:

En igitur tibi Lucretius, et poeta et philosophus maximus uel antiquorum iudicio, sed plenus mendaciorum. Nam multo aliter sentit de Deo, de creatione rerum quam Plato, quam caeteri Academici, quippe qui Epicuream sectam secutus est. Quamobrem sunt qui ne legendum quidem illum censent Cristianis hominibus, qui uerum Deum adorant, colunt, uenerantur. Sed quoniam ueritas quanto magis quaeritur tanto apparet illustrior et uenerabilior - qualis est fides catholica quam Iesus Christus Deus Optimus Maximus, dum in humanis ageret, praedicauit hominibus - Lucretius, et qui Lucretio sunt simillimi, legendi quidem mibi uidentur, sed ut falsi et mendaces, ut certe sunt ${ }^{38}$.

\section{Lucretius elegans modelo de escrita filosófica e teológica}

No antagonismo Lucrécio-Escoto da citada carta de Pico della Mirandola cristalizava um decisivo debate contemporâneo entre filósofos e humanistas. Nesta epístola, Pico surgia como inusitado defensor da Escolástica contra os reiterados ataques dos humanistas italianos, desde as violentas diatribes de Lourenço Valla até aos postulados dos humanistas mais jovens, seus contemporâneos, como Barbaro ou Policiano, igualmente comprometidos com a erradicação da bárbara língua latina escolástica.

O nome de Lucrécio aparecia provocadoramente na pena de Pico como o auctor mais controverso e problemático, do ponto de vista da concepção valense da mera latinitas restaurada, como base primordial e imprescindível para qualquer tipo de discurso, para todas as ciências e saberes. $\mathrm{O}$ caso de Lucrécio, com efeito, punha mais a nu as contradições e os limites da exaltação da pureza e beleza linguística como condição sine qua non para a produção de obras relativas à Filosofia Natural. De acordo com Pico, toda a supremacia formal do autor do De rerum natura não bastava e desde logo não seria possível usá-lo como paradigma, por causa da sua máxima ignorância ou incompetência do ponto de vista doutrinal. Em consequência, até a aridez extrema do latim de Duns Escoto the era superior.

${ }^{38}$ Aldo Manúcio, «Carta-prefácio a Pio Alberto de' Carpi», ed. in Aldo Manuzio editore Dediche, Prefazioni, Note ai testi, introd. Carlo Dionisotti, trad. ital. Giovanni Orlandi, I, Milão, 1975 , p. 153. 
A discussão, em todo o caso, põe de manifesto o facto de que, na Florença estritamente contemporânea do período de formação de Aires Barbosa, a obra de Lucrécio detinha um papel relevante numa controvérsia que se tornará de capital importância para o próprio humanista português (de acordo com a sua produção posterior): a que opunha os partidários de retorizar a Teologia e a Filosofia (na esteira de Valla), e, por outro lado, os defensores da idiossincrasia da linguagem teológica e filosófica, alheia aos paradigmas da Retórica (os defensores do escolasticismo) $)^{39}$.

O autor do comentário a Arátor situa-se claramente nas filas dos antiescolásticos, que apresentavam como antídoto da esquálida teologia escolástica a literatura antiga e patrística e os próprios livros da Sagrada Escritura. Neste ponto, apesar dos impropérios anti-erasmianos do seu Antimoria, Barbosa partilhava a apetência pelas primigénias fontes bíblicas e patrísticas, invocada por Erasmo no seu prefácio In Nouum Testamentum ${ }^{40}$.

Da sua particular batalha declarada contra a linguagem metafísica escolástica dão conta polémicas pessoais com o corpo docente escolástico da Universidade de Salamanca ${ }^{41}$.

É neste quadro, aliás, que a citação de Lucrécio ganha nova luz: De rerum natura proporciona uma mina de exemplos de uma poesia de alta exigência conceptual e da máxima elegância e contenção, privada de toda a ornamentação supérflua. A exposição clara de matérias difíceis e obscuras, princípio estilístico consagrado pelo próprio poeta latino ${ }^{42}$, proporcionava um modelo apto para as diversas tipologias da poesia didáctica ou técnica. Com efeito, o Lucrécio "polymathes» tocara muitos domínios: Física, Metafísica, Política, Ética e também Teologia ${ }^{43}$.

O leitor do Lucrécio explicado por Baptista Pio em 1511 (na esteira de Pontano e $\mathrm{Bembo}^{44}$ ) era confortado, logo na abertura do comentário, com a

${ }^{39}$ A apologia do novo latim teológico, central na obra de Valla, Erasmo e Melanchton, é visível igualmente no comentário a Arátor de Barbosa. Um útil quadro de conjunto desta questão no humanismo italiano e português em Leonel Ribeiro dos Santos, «A Teologia Retórica dos humanistas», in Linguagem, Retórica e Filosofia no Renascimento, Lisboa, 2004, pp. 79-115.

${ }^{40}$ Erasmo, In Nouum Testamentum Praefationes in Ausgerwablte Schriften, ed.latim-alemão W. Welzig, Darmstadt, 1967, vol. III, p. 22. Veja-se a citação e comentário deste passo em Leonel Ribeiro dos Santos, op. cit., pp. 50ss.

${ }^{41}$ É particularmente eloquente o Arii Barvosae Lusitani ad iuuenes studiosos bonarum litteratum praefatio in Secundum Comentarium, ed. e trad. Manso, pp. 92- 121.

${ }^{42}$ Lucr. 1.920ss. A clareza constituía a única virtude de estilo para Epicuro, segundo Diógenes Laércio (Vit. 10.13). Lucrécio criticou a obscuridade de Heraclito (rer. I. 639ss) e considerou a própria linguagem como fonte de iluminação (Lucr. 2.941ss; 2.1114ss.). Cf. o comentário de Bailey a De rerum natura, Oxford, 1972, p. 959.

${ }^{43}$ F. Hallyn, «Poésie et savoir au Quattrocento e au XVIe siècle», in P. Galland-Hallyn et F. Hallyn (dir.), Poétiques de la Renaissance, Genève, 2002, pp. 167-209.

${ }^{44}$ Isabelle Pantin, op. cit., pp. 180ss.; Gambino Longo, «La spositione de Lucrèce...», op. cit., pp. 199-200. 
«vénia» concedida a Lucrécio por parte de Jerónimo, Agostinho e Lactâncio. Os autores patrísticos tinham valorizado a sua fuga do mero ornamento, comandada pela sua vontade de instruir, evocando para este efeito precisamente o livro II, o citado por Barbosa em $1516^{45}$.

No prefácio à referida obra Antimoria, dedicado ao Cardeal-Infante D. Afonso, o humanista luso elabora uma significativa distinção entre a poesia, como disciplina da exactidão e da contenção, e a prosa, como discurso susceptível de expansão sem limite e sem medida. Esta distinção visava atingir a promiscuidade verbal da prosa de Erasmo (undanti solutae uocis eloquio) no seu Encomium Moriae e contrapor-lhe o seu próprio verso na obra Antimoria, verso prudente, submetido às leis métricas, impedido da divagação ${ }^{46}$. Lucrécio proporcionava uma lição exímia neste sentido.

Se alguma dúvida nos assaltasse sobre a importância da leitura de Lucrécio na procura barbosiana de uma norma de escrita poético-técnica, marcada pela exactidão e pela contenção, encontraríamos um sólido argumento na valorização da poesia de Aires Barbosa por parte de um humanista português contemporâneo.

A «Carta-Prefácio» de Jorge Coelho à Antimoria de Barbosa abona o oximoron que nos ocupa: «Li e reli, com avidez e aguilhoada sofreguidão o teu poema de elegância rara, consumado rival do estilo lucreciano; por ele te dou os meus parabéns, à pátria e, em especial, a toda a gente de bom senso» ${ }^{47}$.

Jorge Coelho exaltou a erudição e a elegância formal, à maneira do $D e$ rerum natura, do Antimoria, na qual "pleiteia a sisudez com a erudição, com a leveza a facilidade, com a finura de expressão, a finura do carme» ${ }^{48}$.

$\mathrm{Na}$ Antimoria encontramos efectivamente passos que revelam de maneira indubitável a sua atenta leitura de De rerum natura. Assim o excerto sobre a permanente mudança do mundo, antecipação dos célebres versos camonianos: «Modificações, alternâncias, nascimentos, corrupções - tudo neste mundo, por sua influência, está sujeito a transformações, mudanças, variações, renovações: os elementos da natureza, o seu aspecto geral, o mar, as raças, as terras, os reinos,

${ }^{45}$ Johannes Baptista Pius, op. cit., fol. a vo: etiam postquam Ciceronem Hieronimum, Lactantium Augustinumque danda Lucretio ea uenia: quam sibi libro secundo Manlius deprecatur ita canens: ornari res ipsa negat, contenta doceri.

${ }^{46}$ Aires Barbosa, Arii Barvosae Lusitani Praefatio in Antimoriam ad Illustrissimum S. R. Ecclesiae Cardinalem et Portugaliae Infantem D. Alfonsum, ed. Medeiros, p.135: Erasmus undanti solutae nocis eloquio, qua libitum est illi digredi, excurrit. Nobis placuit prudentium imitari carmen scribentibus, qui pedum numeris astricti, libere diuagari non possumus.

${ }^{47}$ Jorge Coelho, «Georgius Coelius Ario Baruosae suo S. P. D», ed. trad. Medeiros, op. cit., p. 126: Perlegi auido et iandudum sitiente animo elegantissimum tuum poema Lucretianae phraseos foeliciter aemulum in quo non minus tibi et patriae quam omnibus recte sentientibus gratulor.

${ }^{48}$ Jorge Coelho, ed. trad. Medeiros, op. cit., p. 127: Certat cum rerum scientia grauitas; cum facundia uenustas; cum sententiarum acumine carminis elegantia. 
as cidades, os sentimentos, as instituições, as casas, a linguagem. Manifesta tudo o que se oculta sob a terra, oculta o manifesto, ora eleva, ora abaixa a natureza inteira» ${ }^{49}$.

O apreço por Lucrécio, tal como a devoção por Policiano, parece não ter abandonado Barbosa ao longo da sua vida, ainda que, em 1517, o Sínodo florentino tivesse proibido a leitura de Lucrécio nas escolas e também apesar do juízo de Pietro Crinito sobre certa dureza do verso de Lucrécio, apreciação de considerável expansão pela sua inclusão na edição giuntina de $1512^{50}$.

\section{Praecepta sapientiae em De rerum natura}

Jáa referida e consagrada fragmentação escolar de Lucrécio, particularmente valiosa para a aprendizagem da técnica de construção hexamétrica, continha também outra potencialidade (derivada da prática epicurista): a de proporcionar um repositório de enunciados sobre Filosofia Natural fáceis de digerir e memorizar em máximas. Esta potencialidade didáctica técnico-naturalística de Lucrécio, perceptível na sua recepção antiga e medieval (de Cícero a Isidoro, Sisebuto ou Rabano Mauro ${ }^{51}$ e que será aproveitada por Montaigne para a sua própria escrita ensaística ${ }^{52}$, seguramente atraiu também Barbosa.

Particularmente caras ao professor salmantino seriam as advertências de Baptista Pio sobre a necessidade de formação filosófica do «gramático» e a sua insistência na utilidade de Lucrécio no campo da Filosofia Natural. Nos versos do poeta, tal como nos de Empédocles e Varrão, encontravam-se preceitos sábios: qui praecepta sapientiae uersibus tradiderunt $t^{53}$.

O comentário de Baptista Pio ao passo citado por Barbosa incidia no seu significado meramente naturalístico, sem qualquer referência à harmonização com a doutrina cristã. $O$ humanista clarificara o sentido destes versos com o exemplo do caso da chuva ${ }^{54}$.

Ainda que com suprema concisão, Barbosa quis frisar porém a piedade cristã do verso lucreciano (hoc uerum est quatenus Christiane pietati congruit), alguns anos depois, no âmbito hispânico mais confuso das primeiras

${ }^{49}$ Aires Barbosa, Antimoria, ed. trad. Medeiros, op. cit., pp. 161-162: Afficit alternat gignit corrumpit et infral Omnia transformat, mutat uariatque nouatquel Rerum naturam, faciem, mare, nomina, terras/ Regna, urbes, habitus, mores, habitacula, linguas./ Quicquid sub terra est, profert, prolata recondit, / Et sursum uersat et uersat cuncta deorsum.

${ }^{50}$ Fleischmann, op. cit., p. 353.

${ }^{51}$ Fleischmann, op. cit., pp. 349-50.

${ }^{52}$ Emmanuel Naya, «Conclusion», La renaissance de Lucrèce, Paris, 2010, pp. 236-237.

${ }^{53}$ Johannes Baptista Pius, op. cit., fol. a vo.

${ }^{54}$ Johannes Baptista Pius, op. cit., fol. 1xvii vo: cedit retro: reuertitur, retrocedit, omnium rerum quaedam uicissitudo est, exempli ratia pluuia de caelo descendit in terras, e terris scandi in caelum, corpora cum uitae limen attingunt educuntur de corpore materiae, cum obeunt in materiam reuertuntur et ita multiplex est generationis corruptionisque uicissitudo. 
controvérsias doutrinárias. No comentário a Arátor, publicado um ano antes da fixação das célebres teses de Lutero no castelo de Wittenberg, Barbosa registou as suas opiniões acerca das candentes discussões contemporâneas sobre o livre arbítrio e a predestinação, num período anterior à rigidez crescente das divisões doutrinárias: «todos quantos se salvam são resgatados somente pela compaixão divina e não por merecimento algum da sua parte». No entanto, o homem é predestinado porque as suas boas obras, de alguma maneira realizadas a partir do livre arbitrio, são previstas por Deus. Com efeito, embora a justificação ou a gratificação nos auxilie sobretudo a partir do Céu, porém, ela não costuma existir sem a cooperação e a preparação do livre arbitrio. Diz Agostinho: «De facto, quem te fez sem ti não te justificará sem $t i^{55}$.

Esta vontade de congruência parcial entre o poeta materialista e a piedade cristã, como vimos, apostava numa estratégia herdada, patrística (o autor pagão deixava escapar a verdade pela própria força desta), abordagem esta que conviveu na produção humanística com o aberto reconhecimento da irredutível estranheza doutrinal de De rerum natura relativamente ao pensamento cristão.

O extremo laconismo da ressalva barbosiana aponta, por outro lado, para um leitor seguro, confiante nas suas convicções religiosas. Neste ponto, partilhava da premissa de leitura das Vidas dos fllósofos antigos de Diógenes Laércio explicada por Ambrogio Traversari a Cosme de Médicis (si christianum hominem et de deo suo pendentem et cui aeternae uitae spes certa sit ... [...] impensius studuisse comperit ${ }^{56}$ ). Esta forma de confiança caracterizará também a aproximação a Lucrécio do seu célebre comentarista posterior, o «huguenote» Denis Lambin. Este tipo de leitor forte, descendente de Lactâncio, verifica que a luz da verdade é tanta que até o próprio poeta a teria deixado escapar contra si próprio.

Não por casualidade o passo citado por Barbosa foi precisamente também evocado por Lambin, com a finalidade de sublinhar a infiltração da verdade religiosa na obra ímpia do poeta latino:

Acaso não é tanta a força da verdade que até o próprio Lucrécio, no livro anterior, se viu obrigado a confessar imprudentemente que as almas imortais regressam ao céu, de onde partiram? ?7 $^{57}$

${ }^{55}$ Barbosa, Aratoris..., op. cit., pp. 331, 325.

${ }^{56}$ «Fratris Ambrosii ...», in Diógenes Laércio, op. cit., fol. ii.

${ }^{57}$ Denis Lambin, T. Lucreti De rerum natura libri VI..., cit. por Élodie Argaud, «L'autre moitié du projet. Enjeux philosophiques de l'édition du De rerum natura. Lambin et la dissensio sur le corp et l'âme», in La renaissance de Lucrèce, Paris, 2010, pp. 47-82, pp. 53-54: Quid quod tanta uis est ueritatis, ut Lucretius ipse libro superiore animos esse immortaleis, iisque in caelum, unde profecti sunt, reditum patere imprudens atque adeo inuitus fateatur? 
O comentador português de Arátor justifica reiteradamente o seu trabalho como contributo para a necessária formação teológica e ética dos studiosi, contra o monopólio defensivo e especializado dos teólogos escolásticos. De acordo com a interpretação humanística de Lucrécio, o alvo da sua escrita não era o especialista fechado na sua nomenclatura hermética mas o homem secular, ao mesmo tempo contemplativo, que interroga o espectáculo do mundo e tenta encontrar um sentido para a sua vida e para a vida colectiva de todos os homens. De rerum natura era edificante porque procurava para o homem o controlo de todos os medos, alívio para a angústia.

Baptista Pio tinha sublinhado o objectivo de comum utilidade (intentio sane uatis est communis utilitas), a pia intenção de Lucrécio, habilmente relacionado com o venerado Vergílio ${ }^{58}$ :

Esta obra procura libertar a mente, sediada pelas névoas da ignorância, e conduzi-la para aquela felicidade prometida que Vergílio cantava assim: «Feliz aquele que pôde conhecer as causas das coisas e que submeteu aos seus pés todo o medo e o destino inexorável e o fragor do avaro Aqueronte» ${ }^{59}$.

A vontade de harmonização de Lucrécio com a doutrina cristã responde não apenas a uma tendência patrística e humanística, mas também à lógica privada de afinidades electivas de Aires Barbosa.

A sua filologia persegue um objectivo transcendente para além da mera exibição de erudição antiquária individual ${ }^{60}$. Há uma clara e constante fome de finalidade na sua cultura, de uma «meta para onde se dirija e para a qual aponte o arco» (outra pungente citação sua do satírico Pérsio ${ }^{61}$ ). Este objectivo é a identificação de uma norma de vida apta para o homem civil, porque de que aproveita ao homem ganhar o mundo inteiro mas sofrer a perda da sua alma?62.

Esta posição é a espinha do apologético «Prefácio... dirigido aos jovens estudiosos das belas-letras» (Arii Barvosae Lusitani ad iunenes studiosos bonarum litteratum praefatio in secundum commentarium).

O seu comentário a Arátor imprime-se sintomaticamente balizado de alegações de um homem secular que ataca o sentido de posse por parte de

${ }^{58}$ Johannes Baptista Pius, op. cit., fol. a vo.

${ }^{59}$ Johannes Baptista Pius, op. cit., fol. a: In hoc opere intendit mentem nebulis inscitiae circumfusam liberare et ad illam felicitatem inducere quam Maro polliceturam ita canens: "Felix qui potuit rerum cognoscere causas atque metus omnis et inexorabile fatum subiecit pedibus strepitumque Acheronti avari". Cf. Verg. Geor. 2.490-492.

${ }^{60}$ Aires Barbosa, Aratoris..., op. cit., pp. 115ss.

${ }^{61}$ Aires Barbosa, Aratoris..., op. cit., pp. 102-103: «Pergunto-lhes se pensam que o homem nasceu por acaso e em vão, ou se ele tem alguma meta quo tendat, et in quod derigat arcum, como diz o satirógrafo». Cf. Pers. 3.60.

${ }^{62}$ Aires Barbosa, Aratoris..., op. cit., p. 113. 
clérigos exclusivistas e arrogantes relativamente aos assuntos «sacros e celestes»: não são teus os enigmas do direito divino (non tua sunt iuris diuini aenigmata), diz Barbosa a um teólogo que o recriminava porque a obra de Arátor devia ser explicada por um professor de Teologia. O melhor argumento é a reivindicação do sentido total do grammaticus antiquus, cui nullo limite census erat ${ }^{3}$.

Importou ao humanista luso demarcar-se da erudição escrupulosa e infrutuosa (scrupulosa infructuosaque disquisitio) dos miseri philologi, com as suas aniles ac fabulosae uanitates ${ }^{64}$, invocando uma erudição viva, com sentido para além de si própria ${ }^{65}$. Inseria-se assim numa linha crítica às questiúnculas humanísticas meramente eruditas, já fundamental na obra de Erasmo e Vives e característica de certo humanismo extra-pirinaico, no qual encontramos Cornelius Agrippa ${ }^{66}$. Novamente se verifica a confluência substancial de postulados letrados, à revelia da árida contestação que encontramos na Antimoria, onde Erasmo, o moralista da Cristandade, é abusivamente tratado como debochado epicurista.

Tal como Erasmo, Barbosa instrumentalizou todo o saber antigo para a edificação do homem interior invisível e imortal (homo interior, inconspicabilis imortalisque $)^{67}$, até o autor que tinha negado a imortalidade da alma, pois nele encontrava a perspectivação ética ou prática do saber e um modelo poético de contenção formal, assim como a cor retórica apologética que procurava para a sua própria obra.

Com efeito, a Moria, a Loucura, consistia para Barbosa precisamente no abandono dos homens às paixões, coincidindo neste ponto com postulados lucrecianos: Loucura, porém, recorre à perversidade das paixóes para exacerbar a miséria do homem - afastado (mal dele!) por sua cegueira, das bênçãos da luz...68. Não divergia também, em substância, das convicções do próprio Erasmo subjacentes na sua sátira mordaz, o Elogio da Loucura.

\section{O Lucrécio de Aires Barbosa}

Menos seguro e claro é o caminho que conduz ao tipo de manuscrito ou edição de Lucrécio que compulsou o humanista.

${ }^{63}$ Aires Barbosa, «O português Aires Barbosa a um certo teólogo que afirmava que a obra de Arátor devia ser explicada não por um professor de Humanidades mas por um de Teologia»., ed. e trad. Manso, op. cit., pp. 728-729.

${ }^{64}$ Aires Barbosa, Aratoris..., op. cit., pp. 108-109.

${ }^{65}$ Aires Barbosa, Aratoris..., op. cit., pp. 158-159

${ }^{66}$ Jorge A. Osório, «Humanismo e História», in Congresso Internacional Humanismo Português na Época dos Descobrimentos, Coimbra, 1991, pp. 462-63.

${ }^{67}$ Aires Barbosa, Aratoris..., op. cit., pp. 104-105.

${ }^{68}$ Aires Barbosa, Antimoria, ed. trad. Medeiros, op. cit., p. 145: Moria sed caecos a sacro lumine pulsos/ Heu, miseros homines prauis affectibus angit.... 
Já estabelecido na Universidade de Salamanca como professor, e sem excluir a hipótese do manuseio de uma cópia manuscrita ${ }^{69}$,é muito provável que considerasse o campo das edições impressas para ler um texto particularmente rico em termos obscuros, palavras desconhecidas, versos não métricos e formas estranhas.

Por volta de 1516, além das primeiras edições ${ }^{70}$, podia contar com a do camaldulense Petrus Candidus (Pietro da Portico) publicada por Giunta em 1512, edição que só seria superada, em rigor, pelo trabalho de Lambin, impresso em 1564. A Giuntina era a quinta edição da obra e considerava o texto fornecido por Avancius na primeira aldina de 1500 e também o criticismo textual de Policiano, Pontano e Marulo ${ }^{71}$. Ou então já podia recorrer também à edição de Andrea Navagero de 1515, a sexta edição e a segunda aldina, a qual melhorava substancialmente a primeira impressa por Aldo Manúcio em 1500, mas não supôs um avanço decisivo relativamente à edição de 1512 .

A edição de Aldo de 1500 incorporara uma Tabula analítica de assuntos principais de comentário de acordo com a análise humanística, uma forma de fragmentação que facilitava a neutralização doutrinária. Esta prática foi seguida pelas edições seguintes durante o século $\mathrm{XVI}^{72}$.

Barbosa podia contar também com o primeiro comentário humanístico de Lucrécio, já referido, da autoria de Johannes Baptista Pius (acompanhado da consabida aprovação: omnia ortodoxae fidei subiicio), tanto na sua primeira edição (1511) como na reedição de 1514. Precedido de uma praelectio de 1501, o trabalho do humanista bolonhês também dependia, relativamente ao texto oferecido, do texto de Avancius publicado na primeira edição aldina ${ }^{73}$.

Interessa notar que estas três edições de Lucrécio, mais próximas da elaboração do comentário barbosiano, remetiam, em diferentes graus, para o trabalho editorial de Aldo Manúcio, à luz da aparente relevância do modelo

${ }^{69} \mathrm{Um}$ dos manuscritos recentiores de Lucrécio conserva-se na Biblioteca Nacional de Madrid: Nac. 2885 (S). Ostenta marca de copista (Ambrosius scripsit) e de posse (contém o escudo dos Martinozzi de Siena). Segundo Reeve, op. cit., p. 22, tratar-se-ia de um manuscrito dependente de A, o qual conteria as emendas de Antonio Beccadelli (Panormita) ou da sua escola.

${ }^{70}$ À princeps (Brescia, 1473) seguiram-se as de Verona (Paulus Fridenperger, 1486), Veneza (Theodorus de Ragazzonibus, 1495), e finalmente a primeira aldina (Verona, Avancius, 1500); cf. Fleischmann, op. cit., p. 351.

${ }^{71}$ Desta edição conserva-se um exemplar na Biblioteca Nacional de Portugal: Florença, Filipo Giunta, 1512, BNP RES. 2570. Ostenta marca de posse do Colégio de Jesus (Coimbra) (Da «Livraria do Mestre de Matemática»). Da circulação peninsular das outras duas edições referidas dão conta os exemplares conservados na Biblioteca Nacional de Madrid: Venezia, ed. Aldo Manúcio, Dezembro de 1500, BNM INC/1067 e Veneza, ed. Aldo et Andreae soceri, Janeiro de 1515, BNM R/1807.

${ }^{72}$ Fleischmann, op. cit., p. 351.

${ }^{73}$ Desta segunda impressão de 1514 conserva-se um exemplar na Biblioteca Central da Marinha: RDa6-02. 
aldino na Universidade salmantina. Em 1513, quando Demetrius Ducas chegou a Alcalá de Henares, dos catorze textos gregos que possuía a nova Universidade, pelo menos metade saíram da imprensa aldina, de acordo com Lowry $^{74}$. Clive Griffin assinala o volume convincente de indícios que atestam o renome do trabalho editorial de Aldo no seio do humanismo peninsular, incidindo na considerável influência dos tipos aldinos nos exemplares produzidos pelos prelos universitários (Alcalá de Henares e Salamanca) ${ }^{75}$.

Com efeito, a prática editorial aldina tinha sido a imitada pelas edições salmantinas de Prudêncio cum commento, devidas a Nebrija ${ }^{76}$, e Aires Barbosa, o seu herdeiro espiritual ${ }^{77}$, também publicou as suas obras, incluindo o comentário a Arátor, nos mesmos prelos salmantinos ${ }^{78}$.

Uma predilecção especial pelo trabalho editorial de Aldo relativamente a Lucrécio seria de esperar, de resto, no humanista português, porque fora seu condiscípulo no studium florentino, tal como do próprio Papa Leão X, filho de Lourenço de Médecis. José de Pina Martins tem sublinhado a relação especial de Aldo Manúcio com o reino de Portugal, assim como do Papa filo-luso Leão $\mathrm{X}$, patente na carta que abre o Platão grego de 1513, dedicada precisamente a este 'Príncipe da Igreja'79.

A sua lição da obra de Arátor seguia aliás a disponibilizada na primeira edição aldina, assim como o título Historia Apostolica, em vez de De Actibus Apostolorum ou In Apostolorum Acta. Preferia assim a edição impressa por Manúcio e não a posterior, preparada pelo humanista Wilhem Seszler (Estrasburgo, 1507) e impressa pelos Gruniger ${ }^{80}$.

Os três versos do De rerum natura transcritos por Barbosa, no entanto, são bastante enigmáticos, confrontados com este trabalho editorial sobre Lucrécio.

${ }^{74}$ M. Lowry, The World of Aldus Manutius: Business and Scholarship in Renaissance Venice, Oxford, 1979, p. 286. Cf. Martín Abad, La imprenta en Alcalá de Henares (1502-1600), Madrid, 1991, I, p. 82.

${ }^{75}$ Clive Griffin, «Aldus Manutius's influence in the Hispanic World», Aldus Manutius and Renaissance Culture. Essays in Memory of Franklin D. Murphy, Florença, 1998, pp. 323-333, pp. 323ss.

${ }^{76}$ Griffin, op. cit., pp. 324-325.

${ }_{77}$ Manso, op. cit., pp. 52ss.

${ }^{78}$ F. González Vega, «Textus cum commento: ensayo de tipología del libro humanístico», Veleia: Revista de Prehistoria, Historia Antigua, Arqueología y Filología Clásicas VIII-IX (19911992), 449-466.

${ }^{79}$ José de Pina Martins, «Descobertas filológicas e Descobrimentos portugueses numa carta de Aldo Manuzio a Leão X (1513)» in Humanismo Português na época dos Descobrimentos, Coimbra, 1993, pp. 425-437. No mesmo grupo de condiscípulos contava-se também provavelmente o franciscano Urbano da Belluno (1443-1524), professor de Grego na última década de 90 do século XV em Veneza e tutor do futuro Papa Leão X. Vd. Lilian Amstrong, «Benedetti Bordon, Aldus Manutius and Lucantonio Giunta. Old links and new», Aldus Manutius and Renaissance Culture. Essays in Memory of Franklin D. Murphy, Florença, 1998, pp. 161-183, p. 168.

${ }^{80}$ Manso, op. cit., p. 69, n. 241. 
Apresentam lições problemáticas, ausentes nas edições humanísticas referidas: terram (não terras) stellantia (em vez de rellatum/fulgentia) e receptat (em vez de receptant), e também diversas da edição que acompanha o comentário de Baptista Pio, que não lhes dedica qualquer comentário de crítica textual ${ }^{81}$.

Da misteriosa stellantia de Aires Barbosa nada conseguimos encontrar nas edições antigas e modernas consultadas, nem nas de Lucrécio nem nas de Lactâncio, o qual, como vimos, oferece uma valiosa tradição textual indirecta para estes três versos. Também não há vestígios de quaisquer anotações manuscritas a este passo nos exemplares impressos da obra de Barbosa conservados, que poderiam dar-nos alguma pista neste sentido ${ }^{82}$. É possível que o humanista luso citasse de cor a partir da variante «fulgentia», recorrente em Lactâncio, ou talvez tivesse encontrado esta lição num manuscrito desconhecido, ou até - hipótese menos provável - tivesse incorporado uma conjectura silenciosa.

\section{Conclusão}

A ocorrência lucreciana de Barbosa condiz com a recepção «proteiforme» do poeta latino no Renascimento ${ }^{83}$ e responde mais particularmente ao momento lucreciano da formação italiana do humanista luso.

${ }^{81}$ Johannes Baptista Pius, op. cit., fol. lxvii vo.

${ }^{82}$ Surge limpo de qualquer anotação a este passo o exemplar Aires Barbosa, Aratoris Cardinalis Historia Apostolica..., Salmanticae, 1516, BNP Res. 3306V, fol. cxxxvo. O mesmo encontramos no BNP Res. 3307V, com marca de posse «Do Collegio do Porto», muito danificado e bastante anotado com intervenções manuscritas em grego e em latim. Igualmente limpo de anotações na secção em causa, apesar de extraordinariamente anotado noutras secções, está o exemplar BNP Res. 1046//2 A, encadernado com a obra de Santo Tomás de Aquino, sem página de rosto Diui Thomae Aquinatis In tres Psalterum primos nocturnos dilucidissimae expositiones in lucem castigatissimae nuperrime prodeuntes (BNP Res. 1046//1 A). Este exemplar do Comentário a Arátor ostenta numerosas anotações, em grego e em latim, particularmente no livro primeiro, algumas das quais consistem em reacções críticas do leitor da obra de Barbosa. Assim, por exemplo, no fol. iiii, na margem do comentário de Barbosa surge a nota: "Non». Este leitor crítico aplicou o mesmo expeditivo advérbio noutros passos. Veja-se fol. vi. Por seu lado, o exemplar INC. 1536, que apresenta marca de posse «De Bellem», encadernado com um incunábulo de Tertuliano, Q. Septimii Florentis Tertulliani Apologeticus aduersus gentes, Venezia: Bernardino Benali, [não posterior a 1494] oferece no primeiro livro um elevado número de anotações marginais e interlineares, em grego e em latim, de diferentes mãos. No entanto, este testemunho revelador de que a obra de Barbosa foi lida e relida com profusão, também não apresenta no livro segundo, no passo em questão, nenhuma anotação.

${ }^{83} \mathrm{O}$ procedimento tornar-se-á comum a reformistas e contra-reformistas. Encontramos na obra do calvinista francês Philippe Duplessis-Mornay uma forma consumada de utilização de Lucrécio contra si próprio, para destruir o politeísmo e a tese aristotélica da eternidade do mundo: Pr. Duplessis-Mornay, De la verité de la religion chrestienne: contre les Athees, Epicuriens, Payens, Juifs, Mahumedistas et autres infideles, Anvers, Christofle Plantin, 1581. Veja-se a análise de Jean Céard, «Lucrèce et les commentateurs aldines de la Septimaine de du Bartas», La renaissance de Lucrèce, Paris, 2010, pp. 223-231. Cfr. Frank Lestringant, «Ouverture», op. cit., p. 7, Emmanuel Naya, «Conclusion», op. cit., pp. 233-240, 234. 
Enquadra-se na dimensão apologética da obra do professor salmantino contra o escolasticismo, contra o monopólio clerical da Ética e da Teologia, em defesa de uma nova escrita filosófica e teológica, remodelada pela Retórica. A obra de Lucrécio vinha ao encontro da sua vontade de dimensão ética e transcendental para a erudição filológica e da sua procura de uma forma latina depurada.

A aproximação a Lucrécio incide sobretudo na condição plenamente humanística da sua cultura. Contra a opinião de António Rosa Mendes e mesmo considerando a sua 'dramática' contestação a Erasmo, Barbosa dificilmente poderá ser adscrito a esse "pré-humanismo» de cunho anacrónico, arcaizante (ou teologizante) e medieval, que daria passo ao 'verdadeiro' humanismo de vanguarda da geração dos anos 30 do século XVI ${ }^{84}$.

A sua filiação com a vanguarda humanística responde à qualidade da sua formação e à correspondente competência técnica da sua filologia, que em nada deve minorar a polémica anti-erasmista, na medida em que não será aceitável a identificação sumária da competência humanística com a apropriação ou não de postulados erasmistas ${ }^{85}$.

Pelo contrário, há uma linha de continuidade evidente entre Aires Barbosa e André de Resende. A Oratio deste último, de Outubro de 1534, reivindica posições que seriam sem dúvida subscritas e alentadas pelo outrora professor salmantino: a nova teologia, o retorno aos primeiros autores cristãos, a importância do grego para os estudos sagrados, a concórdia enfim da cultura pagã com a cristã.

Também não cabe duvidar de qual seria a posição de Barbosa relativamente a este argumento de André de Gouveia, em carta escrita em Bordéus em 1537 e dirigida ao seu tio, o mais conservador Diogo de Gouveia:

Folgaria que [o senhor meu tio] me ouvisse para ver se a teologia que se aprende pela Sagrada Escritura e pelos Doutores da Igreja é melhor que a sua teologia sofística que se aprende por Tartareto e Durando, nos quais porquanto eu não quis perder o meu tempo tem ele comigo o que tem, porque daqui procede o princípio $^{86}$.

\footnotetext{
${ }^{84}$ António Rosa Mendes, «O pré-humanismo português», in José Mattoso, dir., História de Portugal, 3, «No alvorecer da Modernidade», Lisboa, 1993, pp. 375-421, pp. 375-77.

${ }^{85}$ Como encontramos nos estudos, de resto imprescindíveis, de J. S. Silva Dias. Veja-se, por exemplo, Braga e a cultura portuguesa do Renascimento, Coimbra, 1972, p. 8.

${ }^{86}$ André de Gouveia, "Carta a Diogo de Gouveia», ed. Mário Brandão, O Processo na Inquisição de mestre João da Costa, Coimbra, 1944, p. 273.
} 


\section{Anexo. A estranha lição textual de Aires Barbosa}

\begin{tabular}{|c|c|}
\hline $\begin{array}{l}\text { Aratoris Cardinalis Historia } \\
\text { Apostolica cum Commentariis Arii } \\
\text { Barbosae Lusitani, Salmanticae, in } \\
\text { aedibus Ioannis Porris, Abril de } \\
\text { 1516, Res. 3306V, fol. cxxxvo }\end{array}$ & $\begin{array}{l}\text { terram } / \text { missum est/stellantia/ } \\
\text { receptat }\end{array}$ \\
\hline $\begin{array}{l}\text { T. Lucretii Cari, libri sex nuper } \\
\text { emendati, ed. Hieronimus } \\
\text { Avancius, Venetiis, apud Aldu[m], } \\
\text { Dezembro de } 1500 \text {, fol. d v vo. }\end{array}$ & $\begin{array}{l}\text { terras/missumst/ rellatum/ } \\
\text { receptant }\end{array}$ \\
\hline $\begin{array}{l}\text { In Carum Lucretium poetam } \\
\text { Commentarij a Ioanne Baptista Pio } \\
\text { editi: codice Lucretiano diligenter } \\
\text { emendato..., Bononiae, in ergasterio } \\
\text { Hieronymi Baptistae de Benedictis } \\
\text { Platonici Bononiensis, } 1511, \text { BNP } \\
\text { RES. } 461 \text { A., fol. lxvii vo. }\end{array}$ & $\begin{array}{l}\text { terras/missumst/ rellatum/ } \\
\text { receptant }\end{array}$ \\
\hline $\begin{array}{l}\text { Lucretius, T[iti] Lucretii Cari De } \\
\text { Rerum Natura Libri VI, ed. Pietrus } \\
\text { Candidus, Florentiae, sumpt. } \\
\text { Philippi Guntae bibliopolae, } 1512 \text {, } \\
\text { BNP Res. } 2570 \text { P., fol. xxxvi }{ }^{1} \text {. }\end{array}$ & $\begin{array}{l}\text { terras, missum est, fulgentia, } \\
\text { receptant }\end{array}$ \\
\hline $\begin{array}{l}\text { Opera Firmiani Lactantii..., «Liber } \\
\text { Septimus», «De diuino praemio», } \\
\text { Venettis, per Vincentium Benalium, } \\
22 \text { de Março de } 1493 \text {; BNP INC. } \\
876, \text { fol. p v: }\end{array}$ & $\begin{array}{l}\text { terram/missum est/fulgentia/ } \\
\text { receptant }\end{array}$ \\
\hline
\end{tabular}




\begin{tabular}{|l|l|}
\hline $\begin{array}{l}\text { Lepida Lactantii Firmiani opera } \\
\text { accurate graeco adiuncto castigata..., }\end{array}$ & terram/missum est/fulgentia/ \\
Paris, in vico Diui Iacobi sub Leone & \\
Argenteo, 1509, «Liber Septimus», & \\
«De diuino praemio», BNP, Res. & \\
2950 P., fol. cxlii & \\
&
\end{tabular}

1 Este exemplar in octavo de belíssima encadernação ostenta o non probibetur. Nas anotações sobre variantes que constam no fim do volume Petrus Candidus studiosis s.: legere est in exemplaribus nonnullis [...] ex libro secundo, fols. qviivo-rii, nada consta sobre as variantes do passo em questão.

${ }^{2}$ Este incunábulo, limpo de anotações manuscritas, foi encadernado juntamente com as Vitae de Diógenes Laércio (Venetiis, per Peregrinum de Pasqualibus, 19 de Julho de 1493, BNP INC. 874), e com Tertuliano (INC 875). Tanto o exemplar de Lactâncio como o de Tertuliano carecem de página de rosto.

${ }^{3} \mathrm{Na}$ edição de Lactâncio de Eberhard Heck/ Antonie Wlosok escolhe-se a variante in terras: Lactantius, Divinarum Institutionem libri septem, Liber VII, Berlim, 2011, p. 685. Nas edições impressas de Lactâncio do tempo de Barbosa aparece reiteradamente «in terram». De resto, os editores referidos oferecem as mesmas lições das edições antigas para missum est/ fulgentialreceptant. 


\section{ÍNDICE ONOMÁSTICO}

Adriano VI, Papa: 86

Afonso de Portugal, Príncipe: 14, 19, 27

Afonso V,D. (de Aragão, I de Nápoles): 9

Afonso V, D. (de Portugal): 9, 13, 14, $17,19,20$

Afonso, cardeal-infante D.: 33, 85, 87, 117, 144

Agli, Peregrini: 49

Agostinho, Santo: 122, 144, 146

Agricola, Rodolfo: 32

Agripa, Cornelius: 140, 148

Aguiar, Damião de: 62

Alberti, Leon Battista: 9, 34

Alberto, Príncipe: 63, 73

Albizi, Albiera degli: 51

Alceu: 97

Alcuíno: 25

Alonso de Cartagena: 11, 12

Altilio, Gabriele: 37

Álvares S. I., Pe. Manuel: 56

Álvares, Frei João: 12

Álvares, João, impressor: 20, 28

Anchieta S. I., José de: 113

Andrade, Diogo Paiva de: 58, 59

Andrelino, F.: 39

Andronico, M.: 39

Anghiera, Pedro Mártir de: 15, 85
Apolónio: 83

Aquiles: 37, 47, 120

Arátor: 33, 36, 49, 51, 53, 101, 102, 109, $111,120,121,122,124,128,129,134$, $135,139,143,146,147,148,150$

Ariosto: 112

Aristipo: 136

Aristófanes: 97, 130

Aristóteles: 9,11, 13, 23-25, 49, 138

Arnóbio: 136

Arquíloco: 97

Atrida: 91, 92

Augurelli, Giovanni Aurelio: 40

Augusto, Imperador: 67

Ausónio: 39

Avancius: 149

Azurara (Zurara)

Baldino, Justo: 14

Barbaro, Hermolao: 98, 117, 133, 139, 142

Barbosa, Aires: passim

Barbosa, Fernando: 82

Barreira, João de, impressor: 28

Barreiros, Gaspar: 17

Barros, Frei Brás de: 16

Basílio, São: 23, 137

Beccadelli, António: 149 
Índice onomástico

Belluni, Urbano da: 150

Bembo: 138, 143

Benivieni, Girolamo: 52

Beroaldo, Filippo: 42

Biondo: 34

Boccaccio: 23, 41, 42

Boécio: 63

Boscán, Juan: 31

Braccesi, Alessandro: 39

Bracciolini, Pogio: 9, 11, 137, 138

Braga (Brás de Braga)

Bragança, D. Teodósio de: 29

Brandolini, Aurelio Lippo: 53

Brant, Sebastião: 112

Brás de Braga, Frei: 28

Bruni, Leonardo, Aretino: 9, 12, 20, 22, $23,34,44,45,49$

Buchanan: 62,70

Budé, Guillaume: 30, 32

Cáceres (Lourenço de Cáceres)

Calcagnini, Célio: 42

Campano: 34

Candidus, Petrus (Pietro da Portico): 149

Capece, Scipione: 138

Capri (Pio Alberto de Capri)

Cardon, Horácio: 56

Carísio: 134

Carlos , Duque de Borgonha: 9

Carlos V: 93, 94, 95

Cartagena (Alonso de Cartagena)

Casa, Giovanni della: 30

Castiglione, Baldassarre: 30, 31

Castro, Diogo de: 31

Catulo: 69, 77, 79, 80

Cavaleiro, Estêvão: 21

Clenardo, Nicolau: 26, 27, 28, 29

Colet, John: 32

Conti, Giusto dei: 47

Coripo, Flávio Crescónio: 40
Correia, Manuel: 55, 57-69, 71, 73-79

Corydon: 37,38

Coutinho, Manuel de Sousa: 59, 62

Crasso: 24

Creúsa: 47

Crinito, Pietro: 140, 145

Csezmicei, János (Giano Pannonio)

Cúrcio, Quinto: 9

Camões: 8, 17, 58, 114, 144

Cruz S. I., Pe. Luís da: 8, 55-69, 71, 72, 73, 75-79

Caiado, Henrique: 15, 42, 55

Coelho, Jorge: 17, 37

Cícero: 10, 11, 12, 16, 18, 24, 25, 31, 43, $46,59,60,61,63,90,92,98,136$, 141,145

Daniel, profeta: 68, 76

Dante: 111

Decembrio, Angelo Camillo: 42, 43

Demóstenes: 130

Dídimo de Alexandria: 66, 67, 68, 72, 73,75

Dinis, D.: 13

Diógenes Laércio: 140, 141, 143, 146, 154

Diomedes, gramático: 83

Domingos João, Irmão: 57

Domizi, Pietro: 53

Dovizi, Pietro ou Piero: 49

Duarte, D.: 11, 12, 13

Duarte, Infante D.: 25, 86

Ducas, Demetrius: 150

Duplessis-Mornay, Philippe: 151

Durando: 152

Édipo: 66, 73

Empédocles: 145

Eneias: 47, 68, 129

Epicuro: 135, 136, 141, 143

Erasmo: 7, 15, 27, 29, 32, 34, 85, 98, $118,136,143,144,148,152$

Escoto, João Duns: 133, 142 
Ésquilo: 97

Estácio: 39, 41, 49, 50, 98

Estêvão de Nápoles: 13

Estobeu: 63

Estrabão: 129

Étaples, Lefèbvre de: 32

Etéocles: 97

Eugénio IV, Papa: 11

Everaerst, ou João Segundo: 112

Feltre (Vittorino da Feltre)

Fernandes, Salvador: 11, 18, 22

Fernandes, Valentim: 22

Fernández, Juan, editor: 29

Fernando, D.: 13

Ficino, Marsílio: 9, 34, 45, 49, 50,138, 139

Figueiredo, Catarina: 82

Figueiredo, Martinho ou Martim de: $15,117,139$

Filémon: 63

Filipe III, Duque de Borgonha: 9

Filipe, D. (IV de Espanha, III de Portugal): 58

Flaco, Valério: 41

Floriano, abade: 121

Fonseca, António de: 94

Fonte, Bartolomeo della: 50

Francisco I, Rei de França: 95

Freire, D. Maria: 20

Galharde, Germão: 27

Gama, Paulo da: 114

Genazzano, Mariano da: 53

Gesner, Conrad: 63

Góis, Damião de: 14, 27, 114

Gonçalo, Mestre: 86

Gouveia, André de: 152

Gouveia, Diogo de: 152

Gregório Magno, São: 67, 75

Guarino de Verona: 42, 43, 45, 47, 51, 53

Guazzo, Stefano: 30
Heitor, tesoureiro-mor do reino: 87

Henrique, Infante D.: 12, 13, 25, 26, 29, 86

Heródoto: 18

Hilário de Poitiers: 122

Homero: 7, 46, 47, 49, 98, 130, 140

Horácio: 23, 38, 41, 63, 83, 97, 124, 136

Hutz, Leonardo: 119

Inocêncio VII, Papa: 11

Isabel de Aragão e Castela, Princesa: 14

Isabel de Portugal, Duquesa da Borgonha: 9

Isabel I de Castela, a Católica : 16

Isabel, Rainha Santa: 57

Isidoro de Sevilha: 145

Isota: 45,46

Jaime, D. (Duque de Bragança): 17

Jerónimo, São: 66, 73, 144

Joana, Infanta D. (Santa Joana Princesa): 20

João Crisóstomo, São: 10

João II, D. (de Castela): 9

João II, D. (de Portugal): 9, 11, 14, 15 , $17,18,19,20,21,23,31,37,42,112$

João III, D.: 15, 25, 27, 28, 31, 82, 86, 98, 117

João V, D.: 11

João, D. (Príncipe): 21, 29

Jorge, D.: 23

Juvenal: 39, 44, 122

Juvenco: 102

Lactâncio: 135, 136, 141, 144, 146, 151, 154

Lambin, Denis: 138, 139, 146, 149

Landini, Cristoforo: 45

Leão X, Papa (João de Médicis): 82, 98, 117,150

Leitão, Frei Álvaro: 63

Leonel d'Este: 43

Leonor, Rainha D.: 31

Leto, Pompónio: 17, 139 
Índice onomástico

Lípsio, Justo: 57-65, 67-70, 73, 74, 76, 77,78

Lobo, Álvaro: 58, 72, 73, 75, 78, 79

Lobo, Duarte: 59

Locher, Jacob: 112

Lopes, Fernão: 12

Lourenço de Cáceres: 85

Lovati, Lovato: 35

Lucano: 39, 41

Lucas, São: 129

Lucena, Afonso de, médico: 9

Lucena, Vasco de: 9

Lucena, Vasco Fernandes de: 9, 11, 18, 19

Luciano: 130,131

Lucrécio: 8, 38, 41, 48, 133-152

Luís, Infante D.: 25, 27, 86

Lutero: 146

Macedo, Pe. Francisco: 57

Macróbio: 46, 134

Malatesta, Sigismondo Pandolfo: 45-47

Manílio: 39

Mantuano, Baptista (Spagnoli): 36, 38, 41

Manúcio, Aldo: 120, 121, 142, 149, 150

Manuel I , D.: 14, 15, 19, 20, 22, 26, 31

Maquiavel, Nicolau: 138

Marcelo, Nónio: 134

Marcial: 37, 63, 65-69, 71-77, 79

Marciano Capela: 136

Márcio: 78

Margalho, Pedro: 85

Maria, Princesa D.: 20, 27

Maria, Rainha D.: 14, 20

Marramaque, António Pereira: 31

Marrasio, Giovanni: 44, 45, 48

Marulo: 138, 149

Mateus de Pisano: 13, 17

Mauro, Rábano: 145

Medici, Cosme de: 141, 146

Medici, Lorenzo de: 52, 150
Medici, Piero de: 138

Médicis (Medici)

Melanchton: 143

Mendes, Afonso: 57

Mendonça, Nuno: 62, 64, 68

Meneses, D. Duarte de: 17

Meneses, D. Fernando de, 2० Marquês de Vila Real: 11, 18, 20, 22, 23

Meneses, D. Henrique de: 17

Meneses, D. Miguel de: 20

Meneses, D. Pedro de (1º Marquês de Vila Real): 17, 19

Meneses, D. Pedro de (2o Conde de Alcoutim, 3o Marquês de Vila Real): 11, 13, 20, 22, 24

Meneses, Garcia de: 15, 17, 18

Meneses, João Rodrigues de Sá de: 18,139

Mezêncio: 41

Miranda, Jorge de: 90

Miranda, Sá de: 18, 31

Mirandola, Pico della: 34, 59, 98, 117, $133,137,139,140,142$

Montaigne: 10, 136, 145

Moreira, Hilário: 24

Moreto, João: 59

Murça, Frei Diogo de: 16, 28

Mureto, Marco António: 56, 60

Mussato, Albertino: 39

Namaciano, Cláudio Rutílio: 40

Navagero, Andrea: 139, 149

Navarro, Martin de Azpilcueta: 29

Nebrija, Élio António de: 16, 29, 85, 90 , $102,107,117,118,119,150$

Nelida (Nestor)

Nemesiano: 37

Nesi, Giovanni: 52

Nestor: 91, 92

Nieto, Isabel [esposa de Aires Barbosa]: 39

Noronha, D. Leonor de: 11, 20

Nunes, Pedro: 25 
Núñez (de Gusmán), Hernán: 15, 93

Nuno Álvares de Portugal: 58, 59, 62

Ocampo, Florián de: 93

Oliveira, Gregório de: 62, 80

Osório, D. Jerónimo: 18, 31, 113

Ovídio: 18, 38-41, 48, 98, 129

Palestrina, Giovanni Pierluigi da: 59

Pannonio, Giano (Ianus Pannonius; János Csezmicei): 47, 48, 51, 53

Parma, Basínio de: 39, 41, 45- 47

Pascua, Pedro de: 118

Pastrana, João de: 21

Paulo, São: 101, 109, 120, 131, 133, 136

Pedro, Infante D.: 9, 10, 11, 12, 112

Pedro, São: 101, 105, 120, 121, 133

Perseu: 129

Pérsio: 147

Petrarca: 34, 35, 38- 40, 42

Piccolomini, Ângela: 44

Piccolomini, Enea Silvio (Pio II, Papa): 23,46

Pina, Rui de: 12, 19

Píndaro: 130

Pio Alberto de Capri: 142

Pio II (Enea Silvio Piccolomini)

Pio, João Baptista: 139, 141, 143, 145, 147, 149, 151

Pisano (Mateus de Pisano)

Pitágoras: 46

Platão: 9, 23, 44, 46, 47, 48, 50, 136, 137,141

Plauto: 59

Pletão, Jorge Gemisto: 47

Plínio-o-Moço: 11, 59, 61, 98

Plínio-o-Velho: 122, 129, 139

Plutarco: 10, 23, 24, 31

Policiano, Ângelo Ambrogini : 8, 16, 18, 34-39, 41-44, 48-51, 53, 82, 90, 98, 117, 136, 138, 142, 145, 149

Poliziano (Ângelo Ambrogini Policiano)
Pompónio Mela: 129

Pontano, Giovanni: 30, 34, 39- 41, 138, 143,149

Porres, João de: 119, 128

Portico, Pietro da (Petrus Candidus)

Prado, Afonso do: 28

Prisciano de Cesareia: 83, 134

Probo: 134

Propércio: 98

Prudêncio: 39, 102, 150

Ptolomeu: 25

Quintiliano: 10, 11, 21, 23, 24, 26, 31, 83,97

Rafael: 140, 141

Reis Católicos (Isabel I de Castela e Fernando II de Aragão): 14

Resende, André de: 16, 25, 26, 27, 29 , $86,113,152$

Resende, Garcia de: 15, 19, 31

Rienzo, Cola di: 35

Ripa, Luca: 42

Rocha, João da: 57

Ronsard: 136

Róscio: 66, 73

Rute: 123

Sadoleto, Cardeal: 18

Salústio: 43

Salutati, Coluccio, 9, 23, 34, 42

Sancho de Castela, D.: 85

Savonarola, Girolamo: 42, 52, 53

Scala, Bartolomeu: 138

Sebastião, D.: 31, 57, 59

Sedúlio: 41, 102

Séneca: 10, 11, 39, 41, 59

Serra, João: 90

Serrão, Lopo: 106, 114, 115

Sertório: 65

Sérvio: 134

Sículo, Cataldo Parísio: 11, 14, 15, 17, $18,19,20,22,23,24,26,112$ 
Sículo, Lúcio Marineo: 15, 85, 117

Sigeu, Diogo, de Toledo: 29

Sigismundo da Hungria: 10

Sílio Itálico: 39

Silva, D. Miguel da: 31

Sisebuto: 145

Sisto IV, Papa: 17, 18

Soares, Miguel: 20

Sófocles: 97

Solimão II, Sultão: 95

Sólon: 39

Sousa, D. Diogo de: 21

Spagnoli (Baptista Mantuano ou Battista Mantovano)

Stefaneschi, J.: 39

Strada, Famiano: 61

Strozzi, Hércules: 42

Strozzi, Tito Vespasiano: 34, 38-42, 45, $47,48,51$

Suetónio: 67

Tácito: 59

Tartareto, Pedro: 152

Tassino, Alberto: 42

Tassino, Gabriele: 42

Teixeira, Álvaro: 15

Teixeira, João: 15,18

Teixeira, Luís: 15, 20, 42

Teixeira, Tristão: 15

Teodósio, D.: 88

Teófilo: 110, 111

Terêncio: 44

Tertuliano: 151, 154

Tibulo: 41

Tito Lívio: 43, 98, 122

Tomás de Aquino, São: 151

Trajano: 11

Traversari, Ambrogio: 10, 141, 146

Ulisses: 120

Utrech, Adriano de: 93
Valla, Lourenço: 16, 22, 27, 34, 90, 136, 142,143

Van Giffen: 139

Varrão: 136, 145

Vaseu, João: 27, 29

Vaz, Joana: 86

Verba, Frei João: 112

Vergerio, Pier Paolo: 10, 11

Verino, Ugolino: 38, 39, 52

Verona (Guarino de Verona)

Vettori, Pietro: 138

Vicente, Gil: 31

Vida, Marco Jerónimo: 112

Vigílio, Papa: 101, 121

Virgílio: 22, 38- 41, 43-46, 48- 49, 59, $63,67,74,92,98,106,137,138$, 141,147

Vittorino da Feltre: 10

Vives, Juan Luis: 20, 32, 148

Xenofonte: 9

Zurara, Gomes Eanes de: 12,17 


\section{Volumes publicados na Coleç̧ão Humanitas Supplementum}

1. Francisco de Oliveira, Cláudia Teixeira e Paula Barata Dias: Espaços e Paisagens. Antiguidade Clássica e Heranças Contemporâneas. Vol. 1 - Linguas e Literaturas. Grécia e Roma (Coimbra, Classica Digitalia/CECH, 2009).

2. Francisco de Oliveira, Cláudia Teixeira e Paula Barata Dias: Espaços e Paisagens. Antiguidade Clássica e Heranças Contemporâneas. Vol. 2 - Linguas e Literaturas. Idade Média. Renascimento. Recepşão (Coimbra, Classica Digitalia/CECH, 2009).

3. Francisco de Oliveira, Jorge de Oliveira e Manuel Patrício: Espaços e Paisagens. Antiguidade Clássica e Heranças Contemporâneas. Vol. 3 - História, Arqueologia e Arte (Coimbra, Classica Digitalia/CECH, 2010).

4. Maria Helena da Rocha Pereira, José Ribeiro Ferreira e Francisco de Oliveira (Coords.): Horácio e a sua perenidade (Coimbra, Classica Digitalia/CECH, 2009).

5. José Luís Lopes Brandão: Máscaras dos Césares. Teatro e moralidade nas Vidas suetonianas (Coimbra, Classica Digitalia/CECH, 2009).

6. José Ribeiro Ferreira, Delfim Leão, Manuel Tröster and Paula Barata Dias (eds): Symposion and Philanthropia in Plutarch (Coimbra, Classica Digitalia/CECH, 2009).

7. Gabriele Cornelli (Org.): Representaçóes da Cidade Antiga. Categorias históricas e discursos filosóficos (Coimbra, Classica Digitalia/CECH/Grupo Archai, 2010).

8. Maria Cristina de Sousa Pimentel e Nuno Simões Rodrigues (Coords.): Sociedade, poder e cultura no tempo de Ovídio (Coimbra, Classica Digitalia/ $\mathrm{CECH} / \mathrm{CEC} / \mathrm{CH}, 2010)$.

9. Françoise Frazier et Delfim F. Leão (eds.): Tychè et pronoia. La marche $d u$ monde selon Plutarque (Coimbra, Classica Digitalia/CECH, École Doctorale 395, ArScAn-THEMAM, 2010).

10. Juan Carlos Iglesias-Zoido, El legado de Tucídides en la cultura occidental (Coimbra, Classica Digitalia/CECH, ARENGA, 2011).

11. Gabriele Cornelli, O pitagorismo como categoria historiográfica (Coimbra, Classica Digitalia/CECH, 2011).

12. Frederico Lourenço, The Lyric Metres of Euripidean Drama (Coimbra, Classica Digitalia/CECH, 2011).

13. José Augusto Ramos, Maria Cristina de Sousa Pimentel, Maria do Céu Fialho, Nuno Simões Rodrigues (coords.), Paulo de Tarso: Gregoe Romano, Judeu e Cristão (Coimbra, Classica Digitalia/CECH, 2012). 
14. Carmen Soares \& Paula Barata Dias (coords.), Contributos para a história da alimentação na antiguidade (Coimbra, Classica Digitalia/CECH, 2012).

15. Carlos A. Martins de Jesus, Claudio Castro Filho \& José Ribeiro Ferreira (coords.), Hipólito e Fedra - nos caminhos de um mito (Coimbra, Classica Digitalia/CECH, 2012).

16. José Ribeiro Ferreira, Delfim F. Leão, \& Carlos A. Martins de Jesus (eds.): Nomos, Kosmos E Dike in Plutarch (Coimbra, Classica Digitalia/CECH, 2012).

17. José Augusto Ramos \& Nuno Simões Rodrigues (coords.), Mnemosyne kai Sophia (Coimbra, Classica Digitalia/CECH, 2012).

18. Ana Maria Guedes Ferreira, O homem de Estado ateniense em Plutarco: o caso dos Alcmeónidas (Coimbra, Classica Digitalia/CECH, 2012).

19. Aurora López, Andrés Pociña \& Maria de Fátima Silva, De ayer a hoy: influencias clásicas en la literatura (Coimbra, Classica Digitalia/CECH, 2012).

20. Cristina Pimentel, José Luís Brandão \& Paolo Fedeli (coords.), O poeta e a cidade no mundo romano (Coimbra, Classica Digitalia/CECH, 2012).

21. Francisco de Oliveira, José Luís Brandão, Vasco Gil Mantas \& Rosa Sanz Serrano (coords.), A queda de Roma e o alvorecer da Europa (Coimbra, Classica Digitalia/CECH, 2012).

22. Luísa de Nazaré Ferreira, Mobilidade poética na Grécia antiga: uma leitura da obra de Simónides (Coimbra, Classica Digitalia/CECH, 2013).

23. Fábio Cerqueira, Ana Teresa Gonçalves, Edalaura Medeiros \& JoséLuís Brandão, Saberes e poderes no mundo antigo. Vol. I - Dos saberes (Coimbra, Imprensa da Universidade de Coimbra, Classica Digitalia,2013). 282 p.

24. Fábio Cerqueira, Ana Teresa Gonçalves, Edalaura Medeiros \& Delfim Leão, Saberes e poderes no mundo antigo. Vol. II - Dos poderes (Coimbra, Imprensa da Universidade de Coimbra, Classica Digitalia, 2013). 336 p.

25. Joaquim J. S. Pinheiro, Tempo e espaço da paideia nas Vidas de Plutarco (Coimbra, Imprensa da Universidade de Coimbra, Classica Digitalia, 2013). $458 \mathrm{p}$.

26. Delfim Leão, Gabriele Cornelli \& Miriam C. Peixoto (coords.), Dos Homens e suas Ideias: Estudos sobre as Vidas de Diógenes Laércio (Coimbra, Imprensa da Universidade de Coimbra, Classica Digitalia, 2013).

27. Italo Pantani, Margarida Miranda \& Henrique Manso (coords.), Aires Barbosa na Cosmópolis Renascentista (Coimbra, Classica Digitalia/CECH, 2013). 



\section{OBRA PUBLICADA \\ COM A COORDENAÇÃO \\ CIENTÍFICA}

Centro de Estudos

- U 